\author{
UNIVERSIDADE DE SÃO PAULO \\ FACULDADE DE FILOSOFIA, LETRAS E CIÊNCIAS HUMANAS \\ DEPARTAMENTO DE ANTROPOLOGIA SOCIAL \\ PROGRAMA DE PÓS-GRADUAÇÃO EM ANTROPOLOGIA SOCIAL
}

"Meu Portugal é a aldeia": etnografia de uma dinâmica de circulação migratória e práticas transnacionais

WESLEI ESTRADIOTE RODRIGUES

VERSÃO CORRIGIDA

São Paulo

2013 
UNIVERSIDADE DE SÃO PAULO

FACULDADE DE FILOSOFIA, LETRAS E CIÊNCIAS HUMANAS

DEPARTAMENTO DE ANTROPOLOGIA SOCIAL

PROGRAMA DE PÓS-GRADUAÇÃO EM ANTROPOLOGIA SOCIAL

\title{
"Meu Portugal é a aldeia": etnografia de uma dinâmica de circulação migratória e práticas transnacionais
}

\author{
WESLEI ESTRADIOTE RODRIGUES
}

Dissertação apresentada ao Programa de Pós-Graduação em Antropologia Social da Faculdade de Filosofia, Letras e Ciências Humanas da Universidade de São Paulo, como requisito para a obtenção do título de Mestre em Antropologia Social.

Orientadora: Prof. Dr. Heitor Frúgoli Junior

VERSÃO CORRIGIDA

São Paulo

2013 


\section{Banca examinadora}

Prof. Dr. Heitor Frúgoli Junior (Titular)

Prof. Dr. Igor José de Renó Machado (Titular)

Prof $^{\text {a }}$. Dr ${ }^{\mathrm{a}}$. Ana Claudia Duarte Rocha Marque (Titular)

Prof $^{a}$. Dr ${ }^{a}$. Fernanda Arêas Peixoto (Suplente)

$\operatorname{Prof}^{\mathrm{a}}$. Dr ${ }^{\mathrm{a}}$. Lilia Katri Moritz Scwarcz (Suplente)

Prof. Dr. Omar Ribeiro Thomaz (Suplente) 


\section{RESUMO}

Esta pesquisa é o resultado das observações de caráter etnográfico sobre um recorte proposto para um quadro específico de circulação migratória transnacional. A partir da abordagem de um caso específico, a emigração é tomada de diversas escalas de análise, mas com ênfase sobre os modos pelos quais ela é produzida e significada na esfera local. O quadro enfocado remete aos movimentos sazonais de afastamento e retorno dos emigrantes da aldeia de Vilas Boas, no interior nordeste de Portugal. Procurei seguir os agentes pelos seus deslocamentos entre o contexto de partida e os contextos de destino para os quais rumaram, sem por isso perder de vista a aldeia como foco de seu interesse e da participação social. A maior parte do trabalho de campo, no entanto, se deu no contexto de retorno massivo dos emigrantes para a aldeia para a ocasião de celebração da festa religiosa local. Nesse contexto são observadas as diferentes maneiras pelas quais as o contingente emigrante se relaciona com o grupo que reside na aldeia, bem como os modos pelos quais constroem sua participação na festa e na vida social local. Trata-se, portanto, de uma reflexão sobre práticas que sustentam transnacionalmente relações sociais e as atualizam no reencontro ocasionado pelo retorno.

Palavras-chave: emigração; transnacionalismo; localidade; aldeia; Portugal; relações sociais; festa. 


\section{ABSTRACT}

This research is the result of ethnographic observations about a proposed cut to a particular frame of transnational migratory movement. From the approach of a specific case, emigration is taken from different scales of analysis, but with emphasis on the ways in which it is produced and meant at the local level. The frame refers to the seasonal movements focused on departure and return of emigrants from the village of Vilas Boas, northeast of Portugal. I seek to follow the agents for their displacements between the context of departure and destination contexts for which they headed, without losing the perspective of the village as the focus of interest in social participation of agents. Most of the field work, however, occurred in the context of massive return of migrants to the village for the celebration of a religious festival site. In this context are observed the different ways in which the emigrant group relates to the people residing in the village as well as the ways in which their participation in making the party and the local social life. It is, therefore, a reflection on practices that sustain social relations transnationally and update the reunion caused by return.

Key words: emigration; transnationalism; locality; village; Portugal; social relations; party. 
Aos meus avós e aos meus pais. 


\section{AGRADECIMENTOS}

A ideia de que o trabalho acadêmico é, em grande medida, um esforço solitário foi desconstruída durante a execução dessa pesquisa. Agradeço aqui a todos que de alguma forma compartilharam comigo essa travessia, principalmente aos meus interlocutores do trabalho de campo, pelo diálogo e acolhimento.

Essa pesquisa não seria possível sem o indispensável apoio do $\mathrm{CNPq}$, que me concedeu bolsa ao longo de dois anos. Agradeço igualmente ao Programa de PósGraduação em Antropologia Social da Universidade de São Paulo, pelo suporte acadêmico, com especial atenção aos professores que de alguma forma integraram as etapas desses anos de pesquisa.

Foram de extrema importância, caríssimos, os comentários e críticas da professora Bela Feldman-Bianco (Unicamp) e do professor John Cowart Dawsey (USP) na leitura que fizeram do texto de qualificação. Suas contribuições estruturaram o prosseguimento do trabalho e abriram horizontes importantes. Agradeço também aos professores da banca examinadora, o professor Igor José de Renó Machado (UFSCar) e a professora Ana Claudia Duarte Rocha Marques (USP), pela disposição para discutir o texto final no decisivo momento de encerramento da longa jornada de produção da pesquisa.

Com grande destaque, devo quase todo o agradecimento à zelosa orientação do professor Heitor Frúgoli Junior, com sua dedicação atenciosa e preocupada. Agradeço também aos colegas do Grupo de Estudos de Antropologia da Cidade (GEAC-USP), mesmo àqueles que integraram o grupo no passado, pelo compartilhamento de leituras e pesquisas, mas sobretudo pelo companheirismo: Enrico Spaggiari, Bianca Chizzolini, Guilhermo Aderaldo, Julio Cesar Talhari, Bruno Puccinelli, Karina Fasson, Mayã Martins, Laís Silveira, Giancarlo Machado, Natália Fazzioni, Juliana Blasi Cunha, Marina Rebeca Saraiva e Isadora Fonseca.

Aos colegas do PPGAS/USP, em especial os colegas da Comissão da Sexta do Mês, com quem construí diálogos engrandecedores sobre a antropologia. Agradeço ainda aos amigos que comigo compartilharam a angustiante prova de ingresso no programa de pós-graduação: à grande Tatiane Klein (de muito mais longa data, de momentos difíceis e de celebrações das conquistas), Tatiana Amaral, Karen Shiratori e Tainã Mansani. 
Aos amigos com quem a vida corre junto, Carlos Iramina (desde os remotos tempos de ideias vagas sobre Ciências Sociais), o grande Felipe Marineli, Leandro Kenji, Guilherme Seto Monteiro, João Victor Kosicki, Raphael Meciano e Diego Tavares. Com profundo carinho e reconhecimento pela paciência, compreensão e afeto, agradeço à doce Marina Martins Cipolla. À Angelina Martins, pela ajuda e pelo incentivo sempre disponível. Aos primos, tias e tios, à família. Por fim, com muita ênfase e ímpeto, agradeço aos meus pais, Cecilia Aparecida Estradiote Rodrigues e Elmano José Trigo Rodrigues, sem os quais nada teria sido possível sequer em pensamento, por todo amparo. 


\section{SUMÁRIO}

INTRODUÇÃO. APRESENTAÇÃO. ANTECEDENTES, CONSTRUÇÃO E PROPOSTA

- Paisagens, cenários, agentes e nuances históricos 12

- Aporte, metodologia e epistemologia. Especificidades e problemáticas 21

\section{PARTE 1. DA CIRCULAÇÃO TRANSNACIONAL EM SUAS PRÁticas E LÓGICAS}

CAPÍTULO 1. "A GRANDE DEBANDADA": DE CAMPONÊS A EMIGRANTE, DO CAMPO À CIDADE, E DE VOLTA 37

- 1.1 Preceitos teóricos das relações entre o aporte histórico e o enfoque antropológico dos deslocamentos populacionais 37

- 1.2 Sobre o processo histórico da emigração em Portugal . 44

- 1.3 Esboço de histórico da emigração em vilas boas por meio de seus agentes, ou dos rastros de emigração 54

CAPÍTULO 2. "SENHORA DA ASSUNÇÃO, DAI-NOS BOA VIAGEM": O TRABALHO DA MEMÓRIA E A PRODUÇÃO DA TRANSNACIONALIDADE NO CONTEXTO ESPANHOL 70

- 2.1 "Follow the people" I: pela Espanha 72

- 2.2 "Caminhadas pela cidade": história local e prática espacial 84

- 2.3 Parentesco e vicinalidades: o retorno . 92 
CAPÍTULO 3. "PORTUGAL, TU ME MANQUES": A CIRCULAÇÃO TRANSNACIONAL E O CONTEXTO FRANCÊS 96

- 3.1 "Follow the people" II: pela França . 97

- 3.2 "Para melhorar a vida": o discurso e as práticas dos migrantes 102

- 3.3 “E vós, quando é que vão para baixo?”: a viagem de retorno 116

\section{PARTE 2. RETORNO E FESTA}

CAPÍTULO 4. PENSANDO O TEMPO CÍCLICO DA FESTA: OS SIGNIFICADOS DO RETORNO E DA COMEMORAÇÃO 120

- 4.1 "Meu Portugal é a aldeia": as viagens de retorno e os espaços e elementos da festa 120

- 4.2 "E este ano, vens à festa?": espaços de sociabilidade como lugares de proximidades complexas e distanciamentos tensos 128

- 4.3 Uma economia de dons: temporalidades e dinâmicas da festa 142

PALAVRAS FINAIS. AS DESPEDIDAS E O FECHAMENTO DE UM CICLO CURTO 172 
"Pois eu tenho a sensação de que o estereótipo popular da antropologia é de pessoas indo para lugares distantes e descobrindo coisas estranhas. Minha sensação sobre a antropologia é que ela é de fato um esforço de vida inteira para trazer as coisas de volta para casa e para entender tanto quem somos como, ao mesmo tempo, entender o mundo. Então, nesse sentido, meu caminho é o de volta para casa, de minha própria des-

coberta." (INGOLD, 2012)

“(...) que o saber teórico não é incompativel com o sentimento, que o conhecimento pode ser objetivo e subjetivo ao mesmo tempo"

(LÉVI-STRAUSS, 1989 [1962]: 54) 


\section{INTRODUÇÃO}

\section{APRESENTAÇÃO. ANTECEDENTES, CONSTRUÇÃO E PROPOSTA}

A presente dissertação apresenta os resultados de alguns anos de dedicação ao tema da migração, mais especificamente a emigração portuguesa. Desenvolvo aqui uma investigação antropológica que busca contribuir com as discussões nos estudos promovidos sobre deslocamentos populacionais. A pesquisa tem como intuito, portanto, oferecer algum contributo aos estudos que abordam migrações de grupos humanos, mas pesando sempre de que modo o enfoque antropológico pode produzir conhecimento de modo singular, capaz de enriquecer a compreensão e a abordagem dessa espécie de fenômeno social.

O recorte aqui proposto incide sobre a diáspora portuguesa do século XX. Entre as décadas de 1950 e 1980, significativa parcela da população, sobretudo de origem rural, deixou Portugal para se instalar como imigrante em diversos destinos pelo mundo (Brasil, Estados Unidos da América, Angola, França, Alemanha, Espanha, Luxemburgo, entre muitos outros). Não que a emigração fosse naquele momento histórico algo absolutamente novo para Portugal. Na verdade, era fenômeno antigo conhecido dos portugueses e problematizado por suas classes política e intelectual desde pelo menos o 
século XIX. No entanto, a partir de meados do século XX presenciou-se uma guinada importante no fluxo emigratório tanto em seu aspecto quantitativo, quanto em sua dinâmica própria e suas características.

Portanto, a partir de estudo de caso selecionado e recortado no interior de Portugal, procuro observar a relevância desse marco histórico de destaque para a emigração portuguesa na constituição da dinâmica circulatória transnacional contemporânea. É importante destacar nesse âmbito que, até pelo menos as décadas de viragem da emigração, Portugal era um país de industrialização tardia, ainda em curso, e por isso majoritariamente rural. Embora boa parte de sua população se concentrasse na faixa litorânea, próxima às grandes cidades, quase toda a população do interior do país estava ligada de algum modo ao trabalho no campo ${ }^{1}$. Estou, dessa forma, me reportando a um momento de intensa transformação na estrutura social e de intenso êxodo rural ${ }^{2}$.

A própria concepção da pesquisa teve início quando percebi que esse quadro de êxodo rural e intensa emigração, por meio de um longo e complexo processo, foi fator crucial para a configuração de uma dinâmica singular de deslocamentos e circulação populacional. A intenção foi buscar no plano local uma fonte etnográfica de dados para perceber a conformação da vida cotidiana de emigrantes e não-migrantes a partir da observação mais atenta, ainda que não exclusiva, do contexto de origem. Penso assim a mobilidade da população portuguesa de um ponto de vista que envolve majoritariamente as relações construídas e mantidas com referência aos contextos de partida dos agentes migrantes, ou seja, no contexto dessa dissertação, aldeias do nordeste português.

É relevante dizer ainda que a migração liga-se, em certa escala, a fatores genéricos de ordem socioeconômica, mas busco inseri-la na reflexão como algo que adquire aspectos absolutamente próprios em circunscrições locais. A partir de pesquisa etnográfica busquei entrever os modos pelos quais a emigração é inserida no contexto aldeão e

\footnotetext{
1 Segundo dados do Relatório do Desenvolvimento Humano de 2004 das Nações Unidas, em 1975 a razão entre população urbana e população rural em Portugal era de 0,4, ou seja, mais de $65 \%$ da população portuguesa se encontrava no âmbito rural, enquanto que em 2002 a razão passou a ser de 1,2, ou seja, a população urbana superou a população rural, que passou a ser $45 \%$ do total.

2 Como lembra Antunes a esse respeito desse momento de inversão gradual da proporção entre as populações rural e urbana, "há uma relação muito íntima entre as migrações internas e a emigração, podendo dizer-se que, até certo ponto, elas são duas formas de êxodo rural em Portugal” (1981: 19).
} 
passa a integrar uma lógica prática que articula a reprodução (em seus diversos aspectos, entre eles o material e o simbólico) a estratégias transnacionais de circulação.

Trata-se de explorar etnograficamente um contexto local eminentemente marcado por processos regulares de circulação migratória, de mobilidade pontuada por interesses articulados nos contínuos movimentos de afastamento e retorno. O que pretendo, portanto, é delinear os contornos locais que a emigração assumiu, adotando como referência para isso a aldeia de Vilas Boas, do distrito de Bragança, região de Trás-osMontes, ao norte, próxima da fronteira com a Espanha.

$* * *$

O texto se desenvolve, assim, em diversos planos analíticos. Ao promover a interlocução com outros enfoques disciplinares que abordam as migrações, busco articular um esforço de compreensão num plano mais amplo, em que procuro discutir aspectos relevantes relativos às dinâmicas migratórias contemporâneas. Nesse ponto a abordagem mais propriamente teórica se detém sobre discussões acerca da condição do Estado-Nação (como forma e modelo) mediante as modalidades intensificadas de fluxo transnacional de populações.

A discussão articula a visada local da migração, proporcionada pelo recorte delimitado, a dinâmicas mais amplas da política do Estado-Nação português no espectro do período abrangido pela pesquisa. $\mathrm{O}$ intuito é poder perspectivar no espaço e no tempo as transformações e a constituição da dinâmica migratória enfocada. Esse intento desenvolvo principalmente no primeiro capítulo, onde também pondero as potencialidades e limites das discussões sobre transnacionalismo para pensar o conjunto de dados construído pelo trabalho de observação etnográfica.

Nos demais capítulos o dado etnográfico interpela mais incisiva e decisivamente o esforço analítico de produção do texto. No segundo e terceiro capítulos, que integram a primeira parte da pesquisa, busco trazer dados da observação realizada nos contextos de destino de alguns agentes que colaboraram durante a pesquisa e portanto integram de modo consistente o texto etnográfico. São agentes relacionados à aldeia de Vilas Boas 
que acompanhei e com os quais tive uma interação aproximada na Espanha e na França em seus espaços de moradia, lazer e trabalho.

Já a segunda parte da pesquisa é composta de um único e fundamental capítulo, onde a dinâmica migratória se completa, por assim dizer. $\mathrm{O}$ conjunto imenso de afastamentos não redundou em um desligamento completo entre aqueles migrantes e o contexto de origem. Na verdade, engendrou um quadro novo, transformou as relações em seu aspecto, mas não as dissolveu. Uma temporalidade de afastamentos e retornos mantém ligados emigrantes e aldeões, os que partem e os que ficam, de tal modo que está expressa nos hábitos, expectativas e práticas dos agentes. O período do verão, em especial o mês de agosto, concentra todo o esforço de grande parte dos emigrantes para retornar à aldeia, período em que se celebra grande número de festividades populares em Portugal.

Procuro, dessa maneira, com vistas a essa espécie de retorno pendular e festivo, ponderar se é possível vislumbrar, em meio às práticas e à dinâmica circulatória, novas formas de relação que amparem uma noção de comunidade "entendida mais como população do que como território" (FELDMAN-BIANCO, 1991:90). Busco destacar aspectos da dinâmica emigratória que se sedimentaram. De certo modo, pode-se dizer que a emigração se institucionalizou como um conjunto de possibilidades e saberes. Interessa-me, destarte, aventar as transformações no quadro de relações e práticas que permitiu incluir os movimentos de afastamento e retorno no processo de reprodução (material e simbólica) da aldeia. Para uma perspectiva transnacional, trata-se de uma reconsideração das fronteiras da vida social, ou seja, de levar em conta a prática social através de fronteiras. Dessa consideração é que emerge a noção de "simultaneidade", que remete ao fato de que uma inserção bem-sucedida em um contexto de destino não supõe uma completa desvinculação dos contextos de partida. Nina Glick-Schiller pondera, nesse sentido, que "uma vez que repensamos as fronteiras da vida social, torna-se claro que a incorporação de indivíduos em Estados-Nação e a manutenção de conexões transnacionais não são processos sociais contraditórios" (2004:1003, tradução minha). 


\section{- PAISAGENS, CENÁRIOS, AGENTES E NUANCES HISTÓRICOS}

Durante o decorrer desse trabalho de pesquisa passei por diversos cenários e contextos de observação. Entendi que uma pesquisa que se dedica a pensar o deslocamento de um grupo precisa também se deslocar em alguma medida. Por isso a investigação que teve como ponto de partida a desconstrução da trajetória migrante da minha própria família ${ }^{3}$ se estendeu por uma rede de contatos e relações construídas no trabalho de campo, durante o exercício da pesquisa etnográfica.

O trabalho de observação, portanto, se moveu entre a Espanha, a França e o contexto aldeão em Portugal. Procurei entrever nesses espaços práticas de produção de localidades. Desse modo, o trabalho de descrição dos diferentes cenários e caracterização dos agentes colaboradores se dá ao longo do texto, conforme são descritos os passos que moveram o trabalho etnográfico em diferentes direções. Na Espanha, a construção da interação com emigrantes aposentados do trabalho exercido por décadas na extração de carvão mineral se estruturou em torno da relação encetada com Damião ${ }^{4}$. Essa etapa da observação é descrita adiante, no segundo capítulo.

Quando o trabalho de seguir os agentes pelo campo de suas interações me levou à primeira observação do contexto de retorno à aldeia para celebração das festividades de verão, as relações de pesquisa se multiplicaram significativamente, o que abriu as possibilidades da observação empreendida em Paris, na França. A relação fixada com André permitiram acompanhá-lo até sua vizinhança no subúrbio da capital francesa. A observação participante por entre os cenários, espaços e relações do grupo migrante na França é descrita no terceiro capítulo.

\footnotetext{
3 Um aspecto relevante da concepção e construção dessa pesquisa se assenta no fato de que meu pai é um emigrante da aldeia de Vilas Boas. Adiante, ainda na introdução (e de modo esporádico ao longo do restante da pesquisa), procuro produzir reflexões que procurem atentar para as especificidades e implicações que a proximidade do ponto de partida da construção das questões e problematizações da temática podem, por ventura, ocasionar. Procuro estabelecer um enfoque epistemológico que seja capaz de situar o foco de enunciação da pesquisa e crie as condições de possibilidade da análise, perspectivando os aspectos autoetnográficos relevantes (REED-DANAHAY, 1997; VERSIANI, 2005 e OKELY, 1992).
}

$4 \quad$ Os nomes dos agentes colaboradores dessa pesquisa foram todos substituídos por pseudônimos como forma de preservar suas identidades. 
Por fim, descrevo previamente no tópico a seguir o quadro físico da aldeia, de modo a produzir uma imagem do espaço onde se concentrou a maior parte da observação e das interações produzida pela aproximação produzida em campo.

\section{A aldeia, vilarejo}

Quando em 2011 realizei pela primeira vez pesquisa de campo em Portugal, ao assistir, assim que cheguei, a um noticiário televisivo, curiosamente a primeira notícia informava que naquele verão cerca de trezentas escolas primárias seriam fechadas nas aldeias portuguesas por carência de demanda. O que é sugestivo para iniciar um questionamento acerca das atuais características demográficas dos contextos aldeões em Portugal.

Vilas Boas é uma aldeia do concelho de Vila Flor, no distrito de Bragança, na porção nordeste de Portugal, bastante próxima à fronteira com a Espanha na sub-região do Alto Trás-os-Montes. As aldeias são as menores unidades administrativas do mapa político português. São também a forma pela qual se organizam a moradia e a vizinhança no espaço rural em Portugal. Em geral, são constituídas por um núcleo de habitações na maior parte das vezes bastante antigo, acercado de habitações mais recentes. Nas margens desse conjunto de habitações, nas franjas do espaço de maior circulação, comumente há um trecho ermo de pequenas propriedades rurais mais valorizadas, repletas de olivais, videiras ou trigo (com diferentes aspectos conforme a sazonalidade do cultivo ao longo do ano). Ainda nas delimitações da aldeia mas em perímetro mais afastado ficam os prédios ${ }^{5}$, terrenos menores também destinados ao plantio, menos valorizados por sua posição e em grande parte subaproveitados.

Com relação ao aspecto físico, as aldeias da região nordeste portuguesa, inclusive Vilas Boas, encontram-se em sua maioria em um meio bastante montanhoso e elevado. A maior parte delas se aloca nos vales, relativamente próximas a rios, nas baixadas

\footnotetext{
5 Prédio é o termo usado em Portugal para referir-se a um terreno de pequena ou média extensão e geralmente destinado à agricultura.
} 
mais férteis entre as inúmeras elevações da região. A freguesia ${ }^{6}$ de Vilas Boas, por exemplo, é atravessada pelo rio Tua, margeado pela pequena aldeia da Ribeirinha, onde no passado havia alguns moinhos movidos pela força da correnteza do rio onde se moía todo cereal produzido nas proximidades e que servia à produção doméstica de pães das famílias camponesas.

A aparência das aldeias da região é geralmente muito parecida. Em Vilas Boas, o pavimento onde circulam pessoas e automóveis é todo composto de paralelepípedos de pedra que são corriqueiramente chamados de paralelos e que só passam a ser cobertos pelo alcatrão ${ }^{7}$ na estrada, logo na saída da aldeia - caminho muito utilizado para acessar os centros urbanos mais próximos.

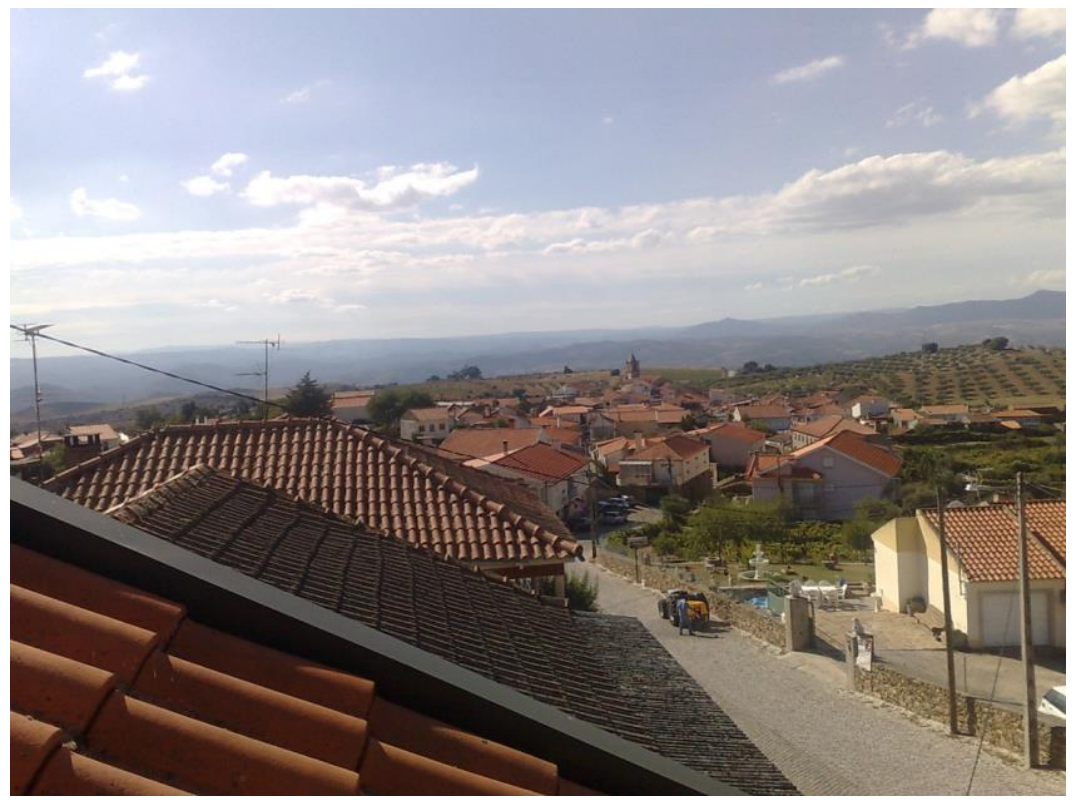

Figura 1. Perspectiva do povoado da aldeia, visto de cima.

Já as casas do núcleo mais antigo, considerado histórico, são feitas de grandes pedras e possuem paredes grossíssimas (antiga forma de produzir uma defesa contra o

6 Freguesia é a unidade administrativa imediatamente superior à aldeia. Vilas Boas é sede de uma freguesia que abarca outras aldeias menores, tais como Meireles e a Ribeirinha.

7 Alcatrão é a forma pela qual o asfalto que cobre ruas e avenidas é chamado em Portugal. 
frio intenso do inverno da região) ${ }^{8}$. Em algumas aldeias esse núcleo de casas e prédios públicos é preservado como patrimônio arquitetônico histórico. Por fora, aquelas que são habitadas são decoradas com pequenos jardins de cravos de diversas cores e outras flores. As casas cujos donos faleceram ou são emigrantes (comumente herdeiros das pequenas moradias dos falecidos pais) permanecem fechadas a maior parte do ano. Grande parte das casas é branca, caiada. Algumas parreiras ornam as fachadas ou varandas. Não há calçadas nas ruas e o pavimento de pedra se estende até a soleira das portas.

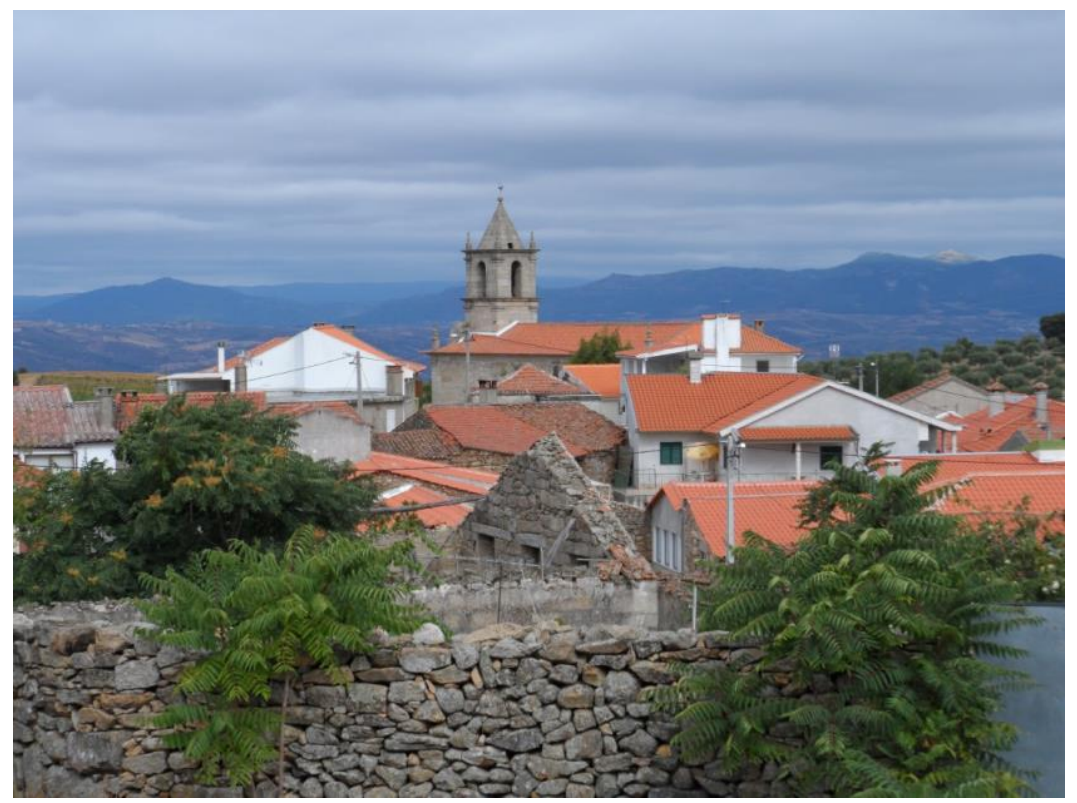

Figura 2. Foto tirada de Vilas Boas em que se pode ver parte da Igreja matriz de Santa Maria Madalena, bem como algumas casas antigas abandonadas e outras mais novas.

O miolo da aldeia de Vilas Boas é fundamentalmente composto por dois grandes largos acercados por ruas radiais. O Largo dos Sotos é o menor, mais próximo do fundo ${ }^{9}$ da aldeia e ponto de parada de uma linha de autocarro ${ }^{10}$, a única que percorre a al-

8 Para uma descrição detalhada da forma e dos aspectos das aldeias portuguesas, ver O’Neill, 1991, pp. 141-166.

9 O termo destacado é nativo e se refere à porção mais baixa da topografia da aldeia, na saída oposta à que dá acesso à sede do concelho e ao santuário local.

$10 \quad$ Modo pelo qual os portugueses chamam os ônibus. 
deia. Nesse largo há um pelourinho com quatro faces e uma pequena escadaria ao seu redor. As imagens grafadas neste pelourinho simbolizam a antiga condição política da aldeia: Vilas Boas era sede de um concelho autônomo até 1836, quando as reformas liberais do império determinaram que fosse anexado ao concelho de Vila Flor ${ }^{11}$. O Largo da Lamela, por sua vez, é bastante maior. Abarca a capela de São Sebastião ${ }^{12}$, além de um segundo pelourinho ${ }^{13}$ e um grande tanque de água alimentado por uma fonte que no passado servia aos animais que acompanhavam as famílias no trabalho diário no campo. No Largo da Lamela há também algumas grandes mansões desabitadas, antigas propriedades das famílias mais ricas e que possuem seus próprios lagares ${ }^{14}$ e capelas ${ }^{15}$. Os dois largos são, portanto, os principais referenciais da aldeia a partir dos quais são descritos diversos percursos. Os principais eventos sociais e religiosos passam pelos largos, entre os quais velórios, festas populares e procissões ${ }^{16}$.

11 É possível, a partir deste evento, delinear uma oposição construída entre Vilas Boas e Vila Flor. Inúmeros aspectos destacam essa oposição, a começar pelo encaminhamento econômico de cada uma: Vila Flor se urbanizou e centralizou a oferta de serviços e empregos, enquanto Vilas Boas manteve os traços eminentemente rurais.

12 Onde são veladas as pessoas que morrem na aldeia.

13 Os largos da aldeia são lugares importantes de passagem dos percursos e, não por mera coincidência, concentram monumentos de importância significativa para a história e a simbologia aldeã. A esse respeito é importante citar que em 2012 as lideranças políticas decidiram organizar uma festa para comemorar os quinhentos anos do foral, documento cedido pelo Rei D. Manuel I que separou Vilas Boas como um concelho politicamente independente de Mirandela. Além da encenação caracterizadamente medievalesca em que praticamente todos os aldeões foram envolvidos, foi instalada no Largo da Lamela uma estátua do rei D. Manuel I, que assinou o comemorado foral, marco da emancipação política da aldeia. A festa foi pensada e desenvolvida pelo presidente da Junta de Freguesia e, além de seu caráter político, carrega significados a respeito de processos de produção de um imaginário sobre o passado e a aldeia imaginada como comunidade.

14 Lagares são os lugares nas propriedades rurais em que se pisavam as uvas e produzia o vinho de consumo diário. Costumava ser um grande tanque com saídas laterais por onde o vinho fermentado escorria e era recolhido após a pisagem das uvas.

15 A senhora Mabel (que tornará a aparecer no primeiro capítulo) disse certa vez a esse respeito que “os ricos não rezavam com os pobres".

16 Como a que celebra os milagres de Nossa Senhora da Assunção, evento de maior importância econômica, social e simbólica da aldeia, e que será descrito e analisado etnograficamente adiante, no quarto capítulo. 
A paisagem nos arredores é bastante uniforme, composta de serras contínuas cobertas principalmente por coníferas e eucaliptos, além de alguma vegetação rasteira, mas composta em grande parte por imensas fragas, grandes rochas erodidas pelo tempo. Em trechos de terra fértil das encostas, são cultivadas azeitona e uva em formações enfileiradas que facilitam as tarefas de plantio e colheita. Os dois principais montes que margeiam Vilas Boas e colocam a aldeia em uma espécie de vale são o Monte de São Cristóvão, popularmente chamada de Talef e coberto de grandes rochas e periodicamente escalado por grupos de aldeões, principalmente os mais jovens, e o Cabeço ${ }^{17}$, a mais alta elevação dos arredores onde repousa o santuário mariano da região.

O santuário é de extrema importância local, sobretudo para a formulação de discursos identitários e a elaboração de formas de auto-representação. É destino de peregrinação na data dedicada à comemoração do dogma da assunção da Virgem Maria ${ }^{18}$ aos céus, no dia quinze de agosto. Além de sua relação com o calendário das comemorações oficiais da Igreja Católica, o santuário se relaciona íntima e profundamente com

17 Cabeço é o termo nativo para se referir ao monte que abriga o santuário de Nossa Senhora da Assunção, que centraliza as atenções durante as festividades populares do mês de agosto. É possível, ademais, entrever as funcionalidades sociais da posição do santuário: por ser o monte mais alto das proximidades, dá destaque visual e simbólico à posição e à imagem do santuário, pode ser visualizado de qualquer ponto da aldeia e, desse modo, permeia de modo quase onipresente o cotidiano dos aldeões.

18 Segundo Lilian Sales, “o catolicismo oficial considera quatro dogmas relacionados à Virgem Maria: maternidade divina, virgindade, imaculada conceição e assunção. Eles foram estabelecidos em datas históricas diferentes pelo Vaticano. Os dois primeiros dogmas possuem fundamento bíblico; já os outros dois (...) foram incorporações de antigas tradições populares pela Instituição [Eclesiástica]. (...) O quarto dogma é a assunção, reconhecido pelo Vaticano apenas no século XX, que concebe que Maria subiu aos céus após sua morte" (2008: 179-181). Portanto, a solenidade da Assunção de Maria foi promulgada como dogma pelo Papa Pio XII, em 1950, e o calendário mariano reformulado pelo Papa Paulo VI, em 1974. Os documentos que definem o estabelecimento do dogma bem como a formulação do atual calendário mariano estão no site oficial do Vaticano, instituição central do poder eclesiástico e da hierarquia da Igreja Católica. Disponíveis em:

http://www.vatican.va/holy_father/pius_xii/apost_constitutions/documents/hf_pxii_apc 19501101_munificentissimus-deus_po.html [Dogma da Assunção] e http://www.vatican.va/holy_father/paul_vi/apost_exhortations/documents/hf_pvi_exh_19740202_marialis-cultus_po.html [Calendário Mariano]

(links consultados pela última vez em 12/09/2013). 
a história local e os modos como a aldeia se imagina como comunidade - e aqui de modo destacável para os interesses desta pesquisa -, inclusive transnacionalmente.

O santuário é visível quase que de qualquer ponto da aldeia. Dista alguns quilômetros do núcleo de casas, já em trecho bastante ermo da paisagem, circundado pela floresta de pinheiros e, atualmente, amparado por um percurso bem ladrilhado e muitos lances de escada que o tornam mais acessível agora do que em momentos no passado, em que a procissão seguia monte acima por uma trilha aberta em meio ao bosque. Ele compõe o que há de mais fundamental no cenário aqui brevemente descrito: um núcleo de habitações ladeado por montes, um dos quais coroado com um santuário denso de significados para a história local.

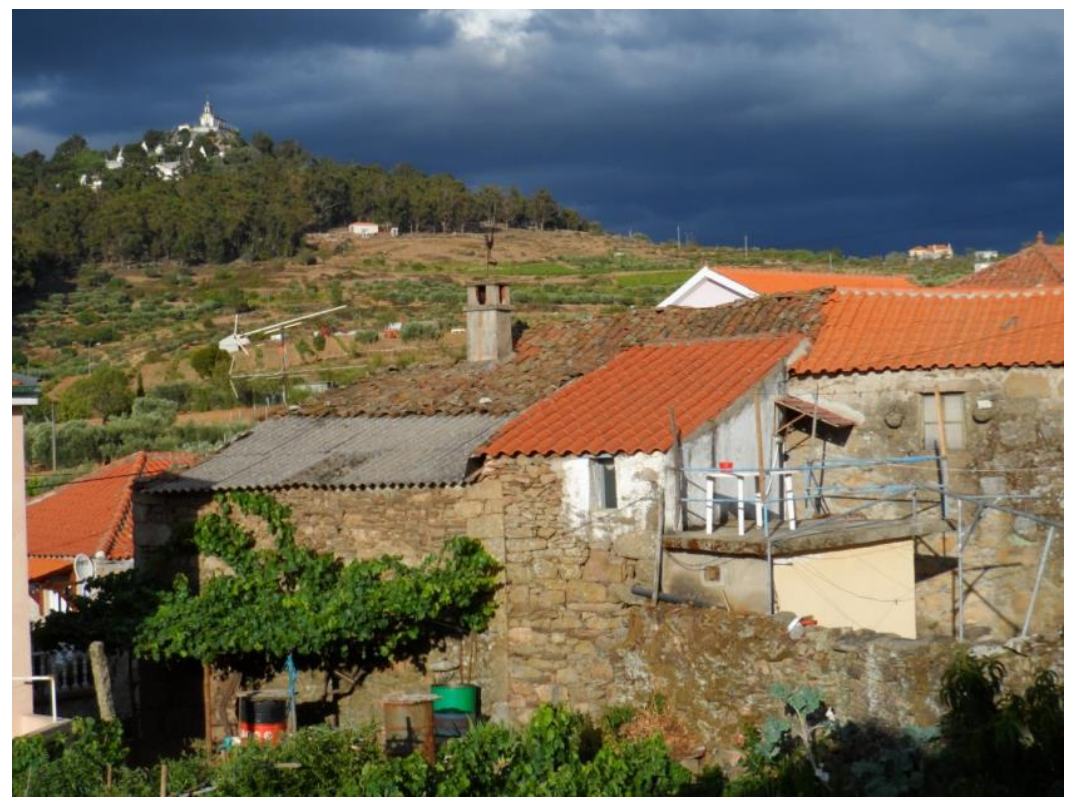

Figura 3. Foto tirada da aldeia que toma o santuário no plano de fundo

Dias extremamente quentes no verão, noites curtas extremamente escuras, ponteadas pelas luzes fugazes das festas populares que pipocam nas aldeotas do lugarejo em agosto. Restam dessa descrição algumas questões, entre as quais "afinal, por que agosto?". A resposta é apresentada adiante e completa a apresentação de um quadro etnográfico complexo, recuperado em algumas breves imagens descritivas, mas também doravante, por meio de um trabalho de exposição analítica das temporalidades que se conformam mediante práticas que se cruzam nesse cenário. 
“Aquele querido mês de agosto" 19 : o cenário festivo

Caracterizar o cenário dessa pesquisa passa invariavelmente pela caracterização do que são as festividades populares que ocorrem no período do verão e que papel cumprem no ciclo migratório as festas populares e arraiais do mês de agosto em Portugal.

A periodicidade das festas populares de verão é conhecida e quase uma regra comum para as aldeias do país. As freguesias em geral concentram no período do verão, principalmente no mês de agosto, a comemoração de festividades de caráter religioso, em homenagem aos santos padroeiros de cada uma delas; enfeitam-se e produzem ciclicamente uma temporalidade festiva extremamente ansiada, sobretudo por aqueles que passam o ano afastados por conta da emigração.

Desse modo, as famílias de emigrantes se organizam e preparam para o mês de agosto. É nesse momento do ano, das festividades aldeãs, que ocorre o fenômeno que originou as questões que motivaram esta pesquisa: boa parte do contingente migrante retorna para a aldeia. Durante o mês de agosto o aguardado verão tem seus dias mais quentes. O curto e intenso verão português é o período do ano para o qual a maioria dos emigrantes agenda suas férias. E nesse intervalo de tempo que passam na aldeia, uma série de práticas e relações se atualizam. O parentesco é reafirmado, bem como relações de proximidade e distância se redefinem e redesenham.

Ao notar essa modalidade de deslocamento periódico e regular, passei a indagar imediatamente quais seriam os interesses mobilizados nessa prática. O intuito da pesquisa, portanto, liga-se menos à percepção da emigração como resultante de fatores mais amplos, de ordem econômica, e mais à apreensão de uma dinâmica absolutamente própria que aponta para um movimento em duas direções, ou seja, para além do afastamento, o retorno. Trata-se de auscultar que série de elementos sustenta a ligação entre os que partem e os que ficam, e permitem perceber a migração não como um desliga-

19 O trecho entre aspas do subtítulo é uma referência ao importante filme homônimo, longametragem de Miguel Gomes produzido em 2008, sobre a temática da emigração e a dinâmica do retorno do ponto de vista das aldeias portuguesas. Para uma análise detalhada do filme, conferir Boto, 2009. 
mento ou ruptura, mas sim como uma distensão do grupo pensado a partir das relações entre os agentes.

Entre os fatores mais explicitamente centrais para a sustentação transnacional dos laços sociais estão as relações de parentesco e a religião. Se por um lado os laços afetivos e os compromissos morais com o grupo familiar parecem estimular a participação continuada do emigrante na vida social da aldeia, por outro a religião cumpre aqui não apenas a função de religar o ser humano ao plano divino, mas também de religá-lo à sua aldeia. Tão intimamente relacionada com a história da aldeia, as comemorações religiosas do mês de agosto congregam, além de romeiros e peregrinos, um enorme grupo de emigrantes que retornam, entre outras coisas, para integrar as celebrações, cumprir alguma promessa ou até mesmo contribuir para sua realização.

Esses festivais anuais são o principal referente para a renovação de um ciclo de afastamento e retorno, ou seja, pontuam a renovação contínua da dinâmica emigratória das aldeias do norte português. O exemplo das festas populares do mês de agosto é fulcral a esse respeito. As festas locais se proliferam e ditam um calendário especial de comemorações. Durante o mês de agosto as aldeias, que na maior parte do ano vivem uma regularidade monótona, revivificam-se com o fenômeno cíclico de retorno anual dos emigrantes.

Assim, é no contexto festivo que culmina todo o processo social aqui enfocado. Não por acaso decidi concentrar o trabalho de campo nessa época do ano. Foram duas investidas similares, de modo tal que em ambas antecedi as festividades em algumas semanas para então poder notar a instituição gradual de uma temporalidade única, propriamente festiva e excepcional, até o clímax das comemorações, quando então a permanência em campo revela as sucessivas despedidas do grupo migrante e a lenta restituição da temporalidade fria e cotidiana da aldeia ${ }^{20}$. dia imediatamente posterior, quando principia o restabelecimento da ordem das coisas e do cotidiano de trabalho. Com o fim das festas em meados do mês, até o final de agosto o esvaziamento da aldeia vai se fazendo sentir morosamente, com despedidas sucessivas e as primeiras rajadas do vento frio das estações mais frias vindouras.
} 
Desse modo, o percurso da pesquisa segue o caminho do trabalho de campo: procurei seguir os agentes em seus deslocamentos. Em duas ocasiões pude observar as formas de construção da vida cotidiana nos contexto de destino, ora na Espanha, ora na França. Em ambas realizei em dado momento o percurso de retorno dos agentes até Vilas Boas. Essas experiências estão registradas no segundo e terceiro capítulos e são seguidas por uma etnografia em solo aldeão, com as observações das práticas de deslocamento, que apresentam de modo mais amplo o campo social que se constitui transnacionalmente. O contexto aldeão em sua complexidade de situações e relações é apresentado no quarto capítulo, onde procuro também ampliar e detalhar a caracterização da festa e seu fundo mítico.

Antes, contudo, realizo uma pausa no texto para indicar algumas abordagens teóricas producentes e, mais importante ainda, para realizar certas reflexões epistemológicas urgentes para situar as condições de produção do trabalho etnográfico mediante implicações de proximidade do pesquisador com o objeto de pesquisa.

\section{- APORTE, METODOLOGIA E EPISTEMOLOGIA. ESPECIFICIDADES E PROBLEMÁTICAS}

Diante de todo o quadro anteriormente exposto, uma pergunta a respeito da constituição da pesquisa se destaca: afinal, por que Vilas Boas? Por que justamente essa dentre os milhares de aldeias do território português se tornou o foco dos interesses de pesquisa?

Nesse ponto da introdução realizo uma pausa estratégica no fluxo narrativo da etnografia tal como vinha sendo apresentada para pensar com cautela o processo de produção da pesquisa e de suas condições de possibilidade prática e epistemológica. E cabe aqui uma questão decisiva e cara para o encaminhamento das reflexões pretendidas: o ponto de partida de todo o plano da pesquisa se encontra bastante próximo a mim, 
talvez excessivamente. Isso porque meu pai foi o primeiro migrante de Vilas Boas de que tive conhecimento da trajetória.

Durante toda minha infância e adolescência habituei-me a ouvi-lo narrar a história de sua vida, com repetida ênfase sobre as difíceis experiências da infância no interior rural de Portugal e as posteriores, em algum sentido traumáticas, experiências de deslocamento migratório. Algumas dessas histórias pessoais de sua trajetória me são tão familiares que passei a considerá-las parte de toda memória de foro extremamente íntimo e familiar.

Ademais, até certo momento da minha vida considerei toda narrativa biográfica elaborada por meu pai como algo que tornava a história da minha família algo absolutamente singular. A pesquisa começou a ser conjecturada quando percebi que, na verdade, a trajetória de afastamento de sua aldeia natal que meu pai percorreu não era assim tão singular. Ou seja, em certa altura notei que a emigração foi a alternativa adotada por um conjunto significativo de outros agentes em contextos semelhantes e que a emigração é tema de interesse de um grande número de pesquisadores enquanto fenômeno sociológico e estatístico de grande relevância, sobretudo na história contemporânea de Portugal.

Um breve levantamento de dados reforça a percepção da amplitude do fluxo emigratório: com larguíssimo alcance, não foi indiferente para a freguesia de Vilas Boas e teve efeitos bruscos e imediatos nas estatísticas. Segundo dados do censo oficial (Instituto Nacional de Estatística - INE-PT), em apenas dez anos entre as décadas de 1960 e 1970 a freguesia de Vilas Boas diminuiu sua população em quase 31\% (de 1.098 habitantes para somente 759), o que representa uma redução drástica causada principalmente pelo êxodo migratório. O concelho de Vila Flor como um todo teve queda similar, em torno de $25 \%$ (de 11.834 para 8.881 habitantes).

Uma rápida observação prévia da aldeia de Vilas Boas pode iluminar alguns aspectos dos efeitos que a emigração gradativamente ocasionou. Além da redução populacional constatada pelos censos decenais, a população residente passou a ser tipicamente mais idosa. São, em grande parte, aposentados que emigraram e retornaram para a aldeia por diversos motivos, ou ainda de idosos que não emigraram, mas cujos filhos e outros familiares sim. Algumas conversas e mesmo as entrevistas que pude realizar des- 
de o início da pesquisa indicam que quase a totalidade dos grupos familiares é atravessada ou tangenciada por alguma experiência migratória.

A emigração portuguesa, no entanto, é objeto de amplo interesse de pesquisadores das mais diversas áreas de pesquisa. A produção bibliográfica sobre o tema é extensa e fértil, sobretudo dos anos 1980 em diante quando foram produzidos diversos estudos referenciais sobre o longo período ditatorial vivido pelo país até 1974. Muitos desses trabalhos vão notar a marca expressiva que as taxas migratórias das últimas décadas do regime salazarista ${ }^{21}$ legaram e analisar aspectos sociais dessa transformação do quadro social, sobretudo através de estudos de caso ${ }^{22}$.

Não se trata aqui, portanto, de agregar volume a esse generoso corpo de estudos sobre a emigração como fenômeno historicamente delimitado, datado. Recorrer a essa bibliografia é uma etapa fundamental, obviamente, mas a pesquisa só se constituiu verdadeiramente quando, desse quadro recuperado, pude recortar uma dinâmica social específica de deslocamentos associados à migração que se reproduz e atualiza contínua e hodiernamente.

No âmbito desses estudos procuro, portanto, vislumbrar por meio dos recortes os modos pelos quais a emigração é criada enquanto prática em certa medida coletiva. Procuro formular uma abordagem da emigração em múltiplas escalas, que não a apreende apenas enquanto fenômeno amplo, genérico e estatístico, mas a partir de um olhar aproximado, procurando entrever como ela é construída, interpretada e representada pelo migrante em suas práticas e em seu discurso.

Destarte, mais do que o fato de minha trajetória familiar ter me levado de algum modo à percepção inicial de um fenômeno amplo e complexo, a pesquisa só pôde se configurar de fato quando, ao aproximar o olhar, pude levantar aspectos de ordem local que configuram uma dinâmica circulatória sazonal e específica. Busquei olhar os deslo-

21 O período ditatorial é referencial para a pesquisa da emigração em Portugal. Embora o fenômeno emigratório tenha ganhado alguma notoriedade anteriormente ao período salazarista, ele atinge seu auge dos anos 1950 em diante. Uma análise mais detida do histórico da emigração portuguesa acompanhada de uma visão das singularidades desse processo no plano local é desenvolvida no primeiro capítulo da dissertação.

22 Como exemplos desses estudos é possível citar Brettell, 1991 [1986]; Poinard, 1983; Antunes, 1981; Reis e Nave, 1986; Rocha-Trindade, 1987 e Pina-Cabral, 1986. 
camentos migratórios transnacionais em suas lógicas extrínsecas, mas principalmente através das características intrínsecas, produzidas nas repetidas experiências práticas do trânsito transnacional.

O enfoque, portanto, se limita a observar um corte transgeracional com o intuito de observar as permanências e mudanças envolvidas na reiterada escolha da emigração como alternativa prática, mas com especial enfoque sobre os grupos que passaram a emigrar desde meados dos anos 1960, período identificado como auge da emigração portuguesa por diversos autores ${ }^{23}$. O recorte situado nesse período exige cuidado com o impacto das transformações do cenário político sobre a dinâmica local de deslocamentos, mas permite lançar uma perspectiva contextualizada das permanências e mudanças da emigração como uma prática que de certo modo integra Vilas Boas, aldeia de tradição rural no interior de Portugal, em um quadro de fluxos de pessoas e bens de ordem transnacional.

\section{Enfoque teórico}

Nesse ponto considero importante apresentar mesmo que de modo sucinto um conjunto significativo de abordagens teóricas e metodológicas que são matrizes das abordagens subsequentes. Assim sendo, começo por destacar que, ao concentrar os interesses de pesquisa sobre uma dinâmica que envolve um número significativo de localidades, fluxos e deslocamentos, aproximei-me do conjunto de abordagens conhecido como "transnational studies". Para os expoentes dessa área de pesquisas, a noção de "transnacionalismo" ganhou espaço ao passo que o número de pessoas mantendo-se ligadas através de fronteiras nacionais em dois ou até mesmo mais Estados-Nação crescia e atribuía eminência à figura do "transmigrante". Nina Glick-Schiller delineia da seguinte maneira o enfoque: 


\begin{abstract}
"Quando falo sobre transnacionalismo ou processos transnacionais, desejo enfatizar as contínuas interconexões ou fluxos de pessoas, ideias, objetos e capital através de fronteiras dos Estados-Nação em contextos nos quais o Estado conforma mas não contém essas ligações e movimentos" (2004b: 449, tradução minha)
\end{abstract}

O conceito de transnacionalismo tem como objetivo maior entrever a complexidade das relações num campo amplo no qual os agentes têm interesses duplamente situados e simultaneamente investidos. O conceito surge como uma ferramenta flexível capaz de auxiliar a abordagem de fenômenos de intensa circulação transnacional, quando relações sociais se distendem através de fronteiras nacionais. Ou seja, trata-se de um modo de encarar as novas dimensões dos fenômenos migratórios e as múltiplas filiações ocasionadas em diferentes contextos de deslocamento populacional.

A emergência de objetos de pesquisa sem delimitações claras, descontínuos no espaço, demanda uma forma de observar que dê conta dessas modalidades de circulação e conexão. A etnografia, por sua parte, passa a abarcar a compreensão de que a abordagem precisa ser tão multi-localizada quanto seu objeto de estudo. A questão passa por reconhecer que o intento não almeja um registro da totalidade do sistema global, mas que cada esforço etnográfico recortado no sistema global é também uma etnografia do sistema. O global, entremeado ao local, emerge das contínuas descrições sobre as ligações e trânsitos entre diversos locais. Esse quadro aventado aponta para um modelo de análise que procura observar os modos pelos quais os quadros locais e a microescala de observação da pesquisa se organizam frente às demandas de larga escala, de ordem global, e dessa maneira ajudam a constituir aspectos da realidade global como sugere Arjun Appadurai (1996: 43; 1997: 34), Ulf Hannerz (1996: 34), Marshall Sahlins (1997). Na verdade, essa perspectiva analítica se recusa a olhar para o local e o global como uma dualidade expressa, um binarismo, mas prima por destacar a articulação intrincada entre esferas que não apenas se relacionam, mas se produzem mútua e dialeticamente.

Desse modo, é por meio de um trabalho de pesquisa pautado pela observação da prática social em localidades ligadas ao processo migratório enfocado que construí uma abordagem da emigração vista de dentro e de perto, como uma prática de definição êmica. Mais do que a compreensão da migração como um problema para a formulação de 
políticas de Estado, interessa aqui encetar um diálogo de onde possam emergir aspectos de uma compreensão nativa dessa prática.

Enfim, trata-se de, a partir do reconhecimento amplo de uma configuração transnacional, realizar um recorte nesse quadro e procurar, pelo adensamento etnográfico, compreender de que modo o espalhamento populacional é um vetor que produz a aldeia, o plano local, por meio da participação intensiva e continuada dos emigrantes através de redes distendidas de relações que envolvem parentesco, afinidades, sociabilidades, rivalidades, vicinalidades, etc ${ }^{24}$.

Dessa maneira, a partir de uma visada local, a pesquisa busca descrever os modos contínuos de produção da aldeia como localidade em alto-relevo na topografia da comunidade transnacionalizada. A dinâmica cultural dos trânsitos migratórios, por meio dos repetidos retornos, termina por dispor a aldeia no centro de uma série de processos translocais. Espécie de nó etnográfico, a aldeia, princípio e fim da análise, constitui o que George Marcus chama de "contexto multi-localizado". Segundo o autor, em locais como esse, a

"percepção do sistema além do sítio particular da pesquisa permanece contingente e não assumida. No entanto, o que se passa no local particular em que a pesquisa é conduzida é frequentemente calibrado em suas implicações pelo que se passa em outro lugar relacionado, ou outros locais, ainda que tais lugares não estejam no enquadramento do projeto de pesquisa ou na etnografia resultante" (1995: 97, tradução minha)

Por esse modo, enquanto a teoria sobre a transnacionalidade ajuda a delimitar o recorte em torno da prática emigratória, a proposta metodológica de Marcus apresenta um modelo de observação que permite ter sempre em consideração as múltiplas locali-

\footnotetext{
24 Arjun Appadurai interpela o problema da reprodução material e cultural dos grupos sociais envolvidos em processos de trânsito transnacional de modo bastante pertinente. Para o autor, a questão que se coloca exige pensar "como pequenos grupos, especialmente famílias, o lócus clássico da socialização, lidam com essas novas realidades globais enquanto buscam reproduzir-se e, ao fazê-lo, reproduzem formas culturais?” (1996: 43, tradução minha).
} 
dades pelas quais circulam e nas quais atuam os agentes da pesquisa. A proposta de um enfoque multi-localizado desloca a perspectiva clássica da etnografia ligada a um sítio delimitado de pesquisa para propor que o trabalho de observação se faça no deslocamento, acompanhando os agentes e as dinâmicas por eles configuradas. Seguir os emigrantes em seus trajetos é um caminho que ajuda porque coloca a experiência etnográfica em movimento e refaz os percursos, recuperando as práticas do deslocamento.

Ademais, embora tenha feito parte do trabalho de campo acompanhando emigrantes em seus lugares de residência na França e na Espanha, a maior parte da pesquisa sucedeu na aldeia, em Portugal. No caso de Vilas Boas, um período de observação é destacável porque concentra um número excepcional de agentes e práticas: trata-se do contexto festivo supracitado. Busco desenvolver, portanto, uma etnografia multilocalizada durante o tempo festivo com o intuito de cruzar espaços e temporalidades da migração.

Não apenas incluída nos percursos de trânsito, mas ponto-focal dos deslocamentos, a aldeia sobressai no contexto festivo. A etnografia da festa, dessa maneira, fornece uma forma de produzir a análise da comunidade não como realidade anterior aos sujeitos, mas, sobremodo, uma história das infinitas técnicas de produção de (trans-) localidades. A pesquisa em solo aldeão executa a premissa de que a adoção de um ponto de observação estrategicamente situado permite aceder mais do que a localidade observada. Adiante, no quarto capítulo, desenvolvo mais extensamente a ideia de uma etnografia multi-localizada no contexto festivo e busco explorar e explicitar as potencialidades desse momento de celebração para a observação de inúmeros aspectos da prática migratória, sobretudo porque se trata de uma espécie de "drama social" no sentido que coloca Clifford Geertz (1989), porque faz convergir múltiplos interesses dos agentes envolvidos.

Esse olhar de relance sobre abordagens que amparam o trabalho não se encerra nesse ponto. Vale dizer que os argumentos se expandem e reforçam ao longo do texto, entremeados às análises dos eventos etnográficos. 
Nota metodológica para uma reflexão "autoetnográfica", ou sobre um "estrangeiro" nem tão "estranho"

Antes, contudo, de abrir definitivamente espaço para o trabalho de contextualização histórica do tema e análise etnográfica, realizo uma pausa de cunho epistemológico. Isso porque, conforme revelado anteriormente, existe nesta pesquisa uma proximidade incômoda entre pesquisador e objeto que precisa de algum modo ser equacionada.

A esse propósito, vale recuperar um jargão corrente entre antropólogos que diz que, em verdade, "não escolhemos o objeto, é ele que nos escolhe". Em seu aspecto metafórico, esse trocadilho comum entre pesquisadores revela que nas escolhas de pesquisa do antropólogo não estão envolvidas tão somente questões objetivas, de uma escolha racional. Antes é preciso reconhecer que a construção do conhecimento antropológico não se faz de modo destacado do plano das relações, que a relação de pesquisa é ela também parte da trama das relações e que o conhecimento é ele próprio uma relação. Portanto, pretendo pensar neste ponto, tal como se propõe Marilyn Strathern, quais são “os tipos de aspiração à compreensão que a antropologia pode e não pode ter" (STRATHERN, 2006: 23).

Cabe expor aqui que a trajetória de vida do meu pai foi a primeira referência de algo que só muitos anos mais tarde, muito depois da infância, eu pude situar em um quadro mais amplo de eventos (históricos, econômicos, sociais) e relações, de inúmeras outras trajetórias, e só então derivar um problema de ordem antropológica. Tamanha proximidade com o fenômeno abordado seria um enorme entrave se o debate epistemológico em antropologia já não tivesse colocado em questão algumas questões relevantes e que pretendo elencar. Sem recuperar o embate epistemológico pertinente, alguns problemas da construção dos dados dessa pesquisa incorreriam em questões delicadas referentes às possibilidades da produção de estranhamento e do lugar em que me situo como pesquisador nos contextos do trabalho de campo.

Toda questão, no entanto, gira em torno do modo de conceber o papel da etnografia como ferramenta metodológica de produção de conhecimento. O que havia de permitir validar a pesquisa de modo ético e êmico era, a um só tempo, explicitar minha condição e erigir uma metodologia própria. Precisei entender portanto que a tarefa cien- 
tífica tal como se objetifica na prática etnográfica, é antes um aprendizado que um mero conjunto de técnicas, e por isso "não se limita a uma transmissão de atitudes ou disposições cognitivas, mas envolve o cientista como pessoa social integral" (SARRÓ e LIMA, 2006: 27) ${ }^{25}$. Essa maneira de conceber a escrita etnográfica, menos como uma técnica e mais como uma forma específica de relação que envolve o pesquisador e os pesquisados, retira da concepção clássica da pesquisa antropológica toda a fantasia positivista de neutralidade absoluta. Não se trata, no entanto, de abordar a produção etnográfica e prática antropológica através de um corte vertical, um dualismo entre a perspectiva clássica e alguns de seus paradigmas, e uma modalidade contemporânea de escrita, que não apaga do texto a presença do antropólogo em campo. O intuito consiste em reconhecer os modos pelos quais o trabalho de campo passou paulatinamente a ser visto como um intervalo espaço-temporal de construção de relações específicas, mediadas pelos interesses e conformadas pela presença do pesquisador.

É, portanto, inevitável classificar esta pesquisa como algo autobiográfica. O ponto de partida marca de maneira indelével o modo como me insiro na pesquisa e o lugar de onde a enuncio. Ele é o referencial, ou ainda, um mote inspirador a partir do qual os horizontes de pesquisa se expandem e revelam um contexto etnográfico amplo e denso de significados e relações. Essa característica biográfica que permeia parte da pesquisa tem sido abordada por alguns antropólogos como uma modalidade etnográfica específica comumente denominada "autoetnografia" (REED-DANAHAY, 1997 e VERSIANI, 2005).

É pertinente, a esse propósito, a discussão realizada por Daniela Beccaccia Versiani (2007) em torno da noção de "autoetnografia". O termo, segundo a autora, é producente para pensar casos em que o antropólogo é também nativo e dessa condição derivam questões de pesquisa. Como opera de maneira flexível, mais propriamente como uma noção do que como um conceito, é importante salientar que a noção de autoetnografia demanda uma apropriação sempre singular e incorpora "nuances de sentido", fun-

\footnotetext{
25 Nas palavras da antropóloga Barbara Tedlock, "porque a etnografia é tanto um produto quanto um processo, nossas vidas enquanto etnógrafos estão intimamente relacionadas com a experiência de campo de tal modo que todas as nossas interações envolvem escolhas e, desse modo, há uma dimensão moral - explicitada ou não - em cada escrito antropológico" (1991: 72, tradução minha).
} 
cionando como "um instrumento construído segundo as necessidades, interesses e motivações de [cada] pesquisa ou reflexão teórica" (VERSIANI, 2005: 106) ${ }^{26}$.

Mas, afinal, o que é e como se caracteriza um registro "autoetnográfico"? Sem passar por nenhum tipo de definição exata, mas procurando acercar a noção, é possível dizer que se trata de

\begin{abstract}
"um neologismo que, entre outras coisas, tenta dar conta das dificuldades do pesquisador contemporâneo às voltas com a complexidade dos objetos que constrói, da percepção complexa e dinâmica que tem de sua própria subjetividade e daquelas de seus interlocutores, e da própria relação que se estabelece entre a subjetividade complexa do produtor de conhecimento e a produção de objetos de estudo, teorias e saber" (Idem: 17)
\end{abstract}

O sentido que adoto, dentre os muitos que o termo pode também assumir referese aos casos em que a experiência individual do antropólogo e elementos de sua história de vida são o princípio a partir do qual o mesmo produz questionamentos de ordem antropológica e constrói maneiras de interpelar o contexto social e assim produzir conhecimento etnográfico. A experiência pessoal do antropólogo incide diretamente em seus questionamentos e em seu modo de escrita. A maneira fundamental de produzir conhecimento nesses casos se ancora em constantes relações entre a biografia do autor e a prática etnográfica. Nesse sentido, autoetnografia é um bom termo para pensar formas

\footnotetext{
26 Versiani localiza nos textos de James Clifford (1986) um aspecto que fundamenta epistemologicamente e presume a consideração da subjetividade do antropólogo como parte constituinte e constitutiva da produção de conhecimento, uma viragem que se desvencilha de qualquer postulado sobre neutralidade para pensar a política imbuída na escrita: “a mudança de paradigma que Clifford aponta (...) refere-se exatamente à não negação da experiência pessoal e, principalmente, à explicitação do "contexto performativo imediato" no qual ocorre a relação interpessoal entre etnógrafo e etnografado como pressuposto básico da construção da própria etnografia" (VERSIANI, 2005: 84).
} 
de transcender dicotomias já muito atacadas na antropologia, que opõem self e sociedade, objetivo e subjetivo ${ }^{27}$.

A própria possibilidade da escrita autoetnográfica repõe no debate antropológico a questão do enunciado etnográfico. Mais do que nunca se torna urgente esclarecer os pontos de onde se fala, de que modo e sobre quem se fala, já que se mantêm sempre iminentes os riscos envolvidos ao se considerar o antropólogo autoetnógrafo como um insider, mais habilitado a falar dos temas que aborda do que qualquer outsider. Essa condição, embora proveitosa, não traz apenas aspectos favoráveis; muito pelo contrário, ela exige um cuidado redobrado com naturalizações despercebidas e afirmações apressadas. Ademais, a dualidade entre insider e outsider é demasiado simplista ${ }^{28}$ para descrever a posição do antropólogo que produz uma autoetnografia, já que o modo como interage e produz representações pode variar contextualmente. É comum e provável que ocorra um jogo situacional em que a proximidade é utilizada como um recurso ora acionado, ora ignorado. Como afirma Reed-Danahay, "não importa se o autoetnógrafo é o antropólogo estudando sua própria condição, contando sua história de vida ou um antropólogo nativo, essa figura nunca está completamente "at home" (1997: 4, tradução minha).

Considerando assim mais uma vez o ponto de partida singular que adoto, é impossível postular pretensamente qualquer espécie de neutralidade ideal-típica. Antes, é

27 Mais do que especialista sobre um campo de conhecimento específico, o antropólogo é o relator das formas de produção de conhecimento pela interpelação da alteridade. Não é como experiência laboratorial que deve se referir ao campo, mas como um conjunto de relações que conjugam discursos sobre práticas, formas de fazer e saber, entre as quais a antropologia é apenas uma possibilidade. Nesse sentido, Versiani sugere "pensar no termo autoetnografia também como método auto-reflexivo e auto-inclusivo do produtor de conhecimento ciente de sua posição circunstanciada, historicizada e contextualizada, como sujeito que se constitui na própria relação com os objetos de sua reflexão, integrado ao universo simbólico ao qual está pesquisando e não destacado dele" (2005:176).

28 Reed-Danahay, ao notar esse aspecto tão presente na antropologia produzida no contexto póscolonial, denominou o autoetnógrafo de "boundary-crosser", possuidor de uma identidade múltipla, cambiante. Tal como no caso de Kwame Appiah, o antropólogo autoetnógrafo circula comumente por espaços sociais de ordem muito diferente e é atravessado e constituído por todos eles de modos e intensidades diferentes. O antropólogo anglo-ganês em seu trabalho "Na casa de meu pai" (1997 [1992]) produz reflexões de interesse antropológico no trânsito que realiza entre sua inserção no âmbito acadêmico e a posição que ocupa no seio de sua família. 
preciso matizar as intenções que articulo e a maneira pela qual me insiro no campo de pesquisa, nem absolutamente estranho, tampouco nativo. No meu caso, destaco que a maneira como me apresentava às pessoas em campo era inevitavelmente dupla: embora falasse primeiramente nos meus intentos de pesquisa, embora explicasse brevemente que realizava ali uma observação da festa e da participação dos emigrantes nela, era quase via de regra interpelado sobre minhas relações de parentesco, forma pela qual muitos buscavam tornar mais inteligível os motivos da minha presença. Essa imposição interposta pelas interações durante o trabalho de campo implicou na construção de um lugar a partir do qual pudesse construir as relações e o diálogo, e isso passava inevitavelmente pelo esforço de apreender o prisma pelo qual eu era percebido pelos agentes em diversas ocasiões.

Vale destacar como aspecto biográfico de grande relevância que não fui criado na aldeia e, antes do trabalho de pesquisa, não conhecia seus habitantes e nem sequer a maior parte dos meus familiares consanguíneos que lá vive. Não cresci nem convivi no ambiente aldeão. Toda a dinâmica migratória que envolve tão intimamente Vilas Boas se tornou familiar para mim tão somente de modo mediado, através da trajetória do meu pai. Portanto, embora a proximidade seja eminente, essa experiência mediada não faz de mim nativo, mas interfere no modo como passei a ser recebido em campo e como algumas modalidades de interação foram construídas.

Desse modo, minha posição inicial em campo era, em certo sentido, ambígua, afinal, eu não era tido nem como emigrante, nem como aldeão. Minha condição era marcada pela necessidade contínua de construção de relações de pesquisa simultaneamente à construção de relações de parentesco, não só por meio da aproximação com o grupo familiar do meu pai, pelo qual fui recebido, mas também ao responder os questionamentos dos diversos agentes a respeito dos modos pelos quais me relaciono com a aldeia e nela me inseri ${ }^{29}$. Esse esforço concentrado para a construção do lugar do pes-

29 Cabe ainda ponderar a esse respeito que, em algumas ocasiões, minha posição em campo estava imediatamente marcada pelo lugar e pelas relações do meu pai (que continuamente me serviu de referencial genealógico) na aldeia. A própria possibilidade de circular, de me inserir e de me situar no lugar estava por vezes associada aos meus vínculos familiares, aos laços de parentesco que me ligavam a algumas pessoas do lugar (vínculos que, algumas vezes, eram o meio pelo qual algumas pessoas entendiam minha posição, mesmo antes de me conceberem como pesquisador). Essas situações aparecerão de modo esporádico ao longo do restante do texto, sempre que a proximidade infletir nas 
quisador em campo é um trabalho de produção das relações de pesquisa e dos espaços de diálogo em que ela se constrói. Ao ser recuperado no texto etnográfico, explicita as bases das relações de pesquisa sem apagar as mediações que baseiam a produção do conhecimento etnográfico. O trabalho antropológico se dá no espaço dos possíveis criado pela ação e as relações produzidas e perseguidas pelo etnógrafo, nas complexas interpelações mútuas entre as subjetividades que constituem o encontro etnográfico.

Retomando as reflexões de Versiani sobre a noção de autoetnografia, começa-se a criar um chão a partir do qual a pesquisa planeja se erguer. $\mathrm{O}$ reconhecimento da subjetividade daquele que registra a escrita é parte, desse modo, de um processo bastante complexo e intersubjetivo de construção desse chão, em que a escrita é resultado imediato da aproximação constitutiva de subjetividades que se interpelam. Aproximando-me um passo mais da noção de "autoetnografia" é importante dizer ainda que

"poderíamos pensar em autoetnografias como espaços comunicativos e discursivos através dos quais ocorre o "encontro de subjetividades", a interação de subjetividades em diálogo. (...) O conceito de autoetnografia permite que o subjetivo e o coletivo não sejam mais percebidos como noções opostas, mas em continuidade, continuidade esta que vai se estabelecendo através da identificação parcial e pontual do sujeito com grupos identitários variados. [Trata-se] da construção de um instrumental teórico (...) que procura lidar com subjetividades e identidades de modo complexo e relacional, e não a partir de oposições" (VERSIANI, 2005: 87-88)

Ao antropólogo cabe, enfim, não somente produzir o estranhamento com relação às práticas nativas, mas um estranhamento com relação a sua própria prática por meio de um extenuante esforço auto-reflexivo. Mais ou menos integrado às relações locais, o antropólogo precisa pôr a nu os afetos como modo de responder a si mesmo sobre que temáticas lhe atravessam e constituem seus interesses, seu olhar, sua sensibilidade, sua

interações de campo. Desse modo, emerge com força a possibilidade de a etnografia centrar-se também na questão de quem o antropólogo é para os nativos e menos em torno de quem são os nativos para o antropólogo (TEDLOCK, 1991:77). 
percepção, enfim, buscar pela auto-reflexividade aceder ao conhecimento entranhado, incorporado (“embodied knowledge"):

"Este modo alternativo de pensarmos a produção de conhecimento exige do pesquisador (...) uma postura altamente auto-reflexiva, pois estes pressupostos o convidam a repensar seu papel de produtor de conhecimento e sua própria subjetividade, que também se constrói interativamente e está circunstanciada por sua singular trajetória intelectual e pessoal, por sua inserção em diferentes grupos socioculturais, por interesses e curiosidades teóricas associadas a escolhas racionais, sim, mas também afetivas e até mesmo casuais e contingenciais, todos elementos que estão presentes na construção de seus objetos de estudo" (Idem: 88-89)

Portanto, o esforço contínuo para situar o antropólogo em campo passa inevitavelmente pelo trabalho de discriminar os modos e ocasiões em que essa proximidade relativa produziu reflexos nas interações e situações do trabalho de campo. Desse modo, das características do trabalho científico, a mais fundamental habilidade para o autoetnógrafo é sempre e mais uma vez produzir estranhamento e "transcender as concepções cotidianas de identidade individual e vida social" (REED-DANAHAY, 1997: 4, tradução minha).

Esse saber incorporado, entranhado nas trajetórias e experiências, carece ser trabalhado como uma episteme. É preciso ver que desde o começo ele se enreda às propostas de produção do conhecimento e da realidade tal como a recortamos, afinal, as perguntas que dirigimos ao objeto são também frutos das nossas trajetórias, condicionadas pelos diferentes marcadores que nos atravessam. 


\section{PARTE 1}

\section{DA CIRCULAÇÃo \\ TRANSNACIONAL EM SUAS \\ PRÁTICAS E LÓGICAS}


"O que significa a localidade em um mundo em que a localização espacial, a interação cotidiana e a escala social não são sempre isomórficas?"

(APPADURAI, 1996: 179, tradução minha)
"Ó oliveira da serra, o vento leva a flor. Óui óuai, só a mim ninguém me leva, Óui óuai, para o pé do meu amor" 30

“A emigração é um fenómeno complexo nas suas causas, condições e resultados. Emigram uns por cálculos e previsões, ou próprios ou dos que os dirigem, pela esperança, bem ou mal fundada, de voltarem algum dia ricos ou abastados à aldeia natal: emigram, não porque não pudessem viver, trabalhando, vida modesta e tranquila entre os seus, mas porque aspiram a mais elevada fortuna. Outros há que emigram violentados, ou antes, que não emigram; que são expulsos pela miséria: que não calculam, nem esperam, nem deliberam; que tão somente se resignam." (HERCULANO, 1879: 68)

$30 \quad$ Canto de trabalho proferido exclusivamente pelas mulheres que trabalham na colheita da azeitona no nordeste de Portugal. 


\section{CAPÍTULO 1}

\section{“A GRANDE DEBANDADA" 31: DE CAMPONÊS A \\ EMIGRANTE, DO CAMPO À CIDADE, E DE VOLTA}

- 1.1 PRECEITOS TEÓRICOS DAS RELAÇÕES ENTRE O APORTE HiSTÓRICO E O ENFOQUE ANTROPOLÓGICO DOS DESLOCAMENTOS POPULACIONAIS

A segunda das epígrafes acima expostas fornece um mote inicial perfeito para esboçar e delinear um quadro etnográfico por meio da maneira oblíqua pela qual introduz as temáticas da discussão aqui proposta. A estrofe aqui reproduzida, proferida em coro e ritmo pelas mulheres durante a colheita da azeitona no interior nordeste de Portugal, no curto espaço de uma pequena quadra rimada, expressa com sutileza poética a angústia que a distância ocasiona. Recurso alegórico justo, remete aqui de modo indireto ao processo pelo qual a diáspora portuguesa incidiu sobre as relações, afastando os

\footnotetext{
31 Termo utilizado pelo historiador Fernando Rosas (1998: 373) para se referir ao período de maior intensidade do fenômeno emigratório na história de Portugal.
} 
agentes e estimulando a pensar os rearranjos que amparam as possibilidade de continuidade dos vínculos sociais entre os sujeitos.

Ao longo das próximas páginas desenvolve-se um ponto nodal da pesquisa, haja vista todo o investimento textual e investigativo despendido para registro e discussão das práticas de circulação transnacional. No primeiro capítulo pretende-se discutir larga e extensamente a etapa do trabalho de campo referente à circulação transnacional, ou seja, aos momentos das investidas ao campo de pesquisa em que estive em movimento em pontos variados e dispersos pelos quais também se moveram (e movem) os agentes colaboradores desta etnografia.

A proposta colocada nessa etapa do texto será a apresentação de uma etnografia multi-localizada, tal como a concebe George Marcus ${ }^{32}$. Como etapa elementar do trabalho de campo, a pesquisa em múltiplas localidades tem vantagens evidentes. Algumas delas estão relacionadas à possibilidade de observação de contextos e práticas de extrema relevância que não se tornariam aparentes com um trabalho voltado ao espaço físico da aldeia. Ademais, esse trabalho de pesquisa é, em parte, um elogio aos deslocamentos populacionais humanos e, como tal, é impensável que se produza de modo fixo. Ao pesquisar durante o movimento, ao acompanhar e, de certo modo, reproduzir o movimento realizado pelo migrante, a pesquisa ganha uma fluidez que ajuda a reconstituir a dinâmica móvel e perene do processo social etnografado.

Além disso, pensar em campos sociais transnacionais sustentados por redes sociais transnacionalizadas demanda um percurso de pesquisa que seja também transnacional, multilocal. Vale pensar, desse modo, a relação de intimidade entre um recorte empírico de práticas de mobilidade espacial e a demanda por um olhar etnográfico igualmente móvel. Nas palavras de George Marcus, trata-se do exercício de uma antropologia em movimento ("anthropology on the move" [1998: 3]).

32 Importa mencionar que se trata em parte de uma modalidade de etnografia móvel, que não se fixa num sítio delimitado de pesquisa, mas que, ligada a referenciais geográficos dispersos, realiza-se sobretudo na observância da "circulação de significados, objetos e identidades num tempo-espaço difuso" (MARCUS, 1996: 79, tradução minha). Esse trabalho de pesquisa encaminha-nos a uma consideração que integra global e local pela elaboração de uma abordagem multi-localizada, tal como a propõe George Marcus. A partir dessa consideração entendo que "tal como esse modo investiga e constrói etnograficamente os modos de vida de sujeitos variadamente situados, ele também constrói etnograficamente aspectos do sistema global através das associações e conexões que sugere entre lugares" (1995: 80). 
No entanto, é preciso também reconhecer os limites e as dificuldades de um trabalho de cunho multi-localizado. As possibilidades de acompanhar os atores ao longo das conexões transnacionais que estabelecem são condicionadas por um grande número de fatores limitantes. Procurei realizar esses trânsitos e, sempre que possível, busquei estar em movimento pelas rotas de deslocamento comumente traçadas pelo grupo migrante observado. E é no espaço das páginas desse primeiro capítulo que pretendo portanto descrever as experiências móveis a que me expus no decurso desses momentos.

O capítulo começa com uma reconstituição do processo emigratório português no decurso do século XX, sobretudo em sua segunda metade, com o intuito de olhar para o atual contexto de deslocamentos populacionais como algo relacionado a um processo maior, mais antigo e em constante transformação. A ideia é ter uma noção ampla do elemento histórico que envolve os fatos observados, e que perpassa transversalmente toda a pesquisa, para por meio disso realizar posteriormente uma aproximação significativa do caso estudado e levantar também as especificidades proporcionadas pela emigração no plano local.

Através dessa reconstituição de elementos envolvidos no transcurso das últimas décadas em Portugal, passo então a pensar a história muito menos através dos grandes eventos, buscando revelar uma história não-linear, descolada de determinações relacionadas exclusivamente à história do Estado-Nação português. Não se trata, portanto, de tomar o Estado e seu discurso oficial como realidades imanentes, nem de simplesmente aboli-los da análise (sob alegações vagas a respeito da relatividade histórica da forma do Estado ou de quaisquer indícios de seu esboroamento), mas de percebê-lo a partir de uma "perspectiva resolutamente processualista" (GOLDMAN e NEIBURG, 2002: 205). Ao situar o discurso nacional e o Estado-Nação como uma agência importante, uma ação que se coloca em curso entre ações, é fundamental dar conta de sua "historicidade profunda, ou seja, o fato de ser continuamente construído na história e nas relações sociais, políticas e culturais" (Idem).

Desse modo, é importante assinalar que as críticas lançadas por uma abordagem transnacional incidem sobre o fato de que nunca, e menos ainda no atual momento, a pretensão de unidade absoluta do Estados-Nação serviu de limite para o espaço de ação dos sujeitos. O Estado, contudo, não desaparece nas abordagens transnacionais sob uma névoa desconstrutivista, mas é, em vez disso, deslocado da centralidade que lhe é comumente atribuída nos estudos que acabam por naturalizar as fronteiras nacionais 
como aquelas que encerram os tropos da pesquisa e da ação social. A esse entrave teórico tipificado Nina Glick-Schiller denomina "nacionalismo metodológico". Nas palavras da autora, "nacionalismo metodológico é a tendência a aceitar o Estado-Nação como um dado na análise social" (2004a: 1007, tradução minha). Essencialismo dos mais comuns, está contido como premissa não refletida, ponto-cego de grande número de pesquisas, capaz de extrair-lhes a historicidade fundamental à observação de práticas e instituições.

A fim de esquivar-me dessa modalidade de premissa busco lidar, desde então, com a história percebida a partir da observação atenta e aproximada da trama cotidiana das relações com o propósito de construir uma história da migração a partir dos deslocamentos e relações dos sujeitos. Sem excluir o Estado do escopo das considerações, concentro, no entanto, minhas forças na observação das práticas cotidianas e busco aqui apresentar uma visão da emigração que possa advir dos próprios migrantes, uma percepção do deslocamento a partir dos sujeitos que se deslocam. Como sugere Jacques Revel, pretendo

\begin{abstract}
"construir uma modalidade nova de uma história social, atenta aos indivíduos percebidos em suas relações com outros indivíduos. Pois a escolha do individual não é vista aqui como contraditória à do social: ela deve tornar possível uma abordagem diferente deste, ao acompanhar o fio de um destino particular - de um homem, de um grupo - e com ele a multiplicidade dos espaços e dos tempos, a meada das relações nas quais ele se insere" (1996: 21). ${ }^{33}$
\end{abstract}

Neste momento é importante reincidir na ideia de que a pesquisa realiza uma investigação que se movimenta junto com seus interlocutores. Enuncio uma proposta de aproximação de uma dinâmica migratória marcada por contextos variados, mas que em sua circularidade aponta para o interior nordeste de Portugal, espaço da primeira socia-

33 Jacques Revel e Caroline Brettell parecem concordar nesse aspecto. Brettell, por sua parte, afirma que "uma abordagem antropológica da migração deve enfatizar ambos, estrutura e agência; deve observar em nível macro aspectos contextuais, em nível micro estratégias e decisões, e em nível meso, estruturas relacionais em que operam os indivíduos. Isso demanda articular ambos, pessoas e processos" (2003: 7, tradução minha). 
lização dos sujeitos que sustentam essa dinâmica, para onde convergem suas práticas coletivas. Tal como distingue a socióloga Peggy Levitt (levando em conta as formulações conceituais de Michael Kearney [1995]), "processos transnacionais são ancorados em e transcendem um ou mais Estados-Nação" (2001: 14, tradução minha).

O trabalho de pesquisa decorreu assim tendo sempre em consideração um referencial geográfico situado no interior de Portugal. A diáspora em questão, vista em todo o seu processo de formação, constitui uma dinâmica regular de mobilidades que se volta periodicamente para Vilas Boas. A realidade emigratória portuguesa configura, portanto, no recorte aqui proposto, um caso que denomino de "aldeia transnacional" ${ }^{34}$. E é em referência a esse quadro de práticas transnacionais que levanto questões para uma abordagem de pesquisa que procura pensar de que modo a emigração, que se configurou como tendência mais ou menos marcada na história do último século em Portugal, ${ }^{35}$ pode ser pensada como uma prática que adquire regularidade e que pode ser também entendida, sobretudo se vista localmente, como uma prática ou, a bem dizer, uma dinâmica social.

Procuro a partir do recorte de um quadro etnográfico localmente delimitado, empreender um estudo que aborde a emigração como algo processual que, embora ligada a aspectos mais amplos, ganha contornos e conteúdos absolutamente singulares em dimensões microanalíticas. Desse modo, "o projeto é fazer aparecerem, por trás da tendência geral mais visível, as estratégias sociais desenvolvidas pelos diferentes atores em função de sua posição e de seus recursos respectivos, individuais, familiares, de grupo, etc." (REVEL, 1996: 22).

Suscito, desse modo, construir uma abordagem transnacional do fenômeno emigratório que possa colocar em perspectiva, a partir de um estudo de caso bastante recortado, os modos de relação e colaboração intensiva entre migrantes e residentes da aldeia de Vilas Boas desde o momento emigratório mais frenético, por volta dos anos 1960. O

\footnotetext{
34 Tradução de “Transnational village” (LEVITT, 2001: 10).

35 As referências ocasionais à conformação emigratória desde o século XIX constituem tão somente uma maneira de pensar o modo de gestação de um processo que passou por diversas modificações contextuais e amplas, dentre as quais aquelas que sucederam a partir da segunda metade do século XX têm ainda mais relevância e precisam ser consideradas com maior ênfase para os efeitos aqui pretendidos.
} 
enfoque transnacional que pretendo elaborar passa pela ideia expressa por GlickSchiller de apoiar a ênfase da análise em fluxos variados, de pessoas, objeto e capitais:

\footnotetext{
"Quando falo sobre transnacionalismo ou processos transnacionais quero enfatizar as interconexões contínuas ou fluxo de pessoas, ideias, objetos e capital através das fronteiras dos Estados-Nação em contextos em que o Estado conforma mas não contém essas ligações e movimentos" (2004b: 449, tradução minha)
}

O destaque conferido ao plano relacional pretende apreender os comportamentos e incorporar os sujeitos como agentes envolvidos numa trama múltipla de outros agentes, tempos e espaços. A perspectiva que adoto, baseada num aporte relacional, pensa a configuração de "campos sociais transnacionais" que "formam uma rede das redes que nos permite mapear as conexões indiretas entre diversos indivíduos" (GLICKSCHILLER, 2004:457-8, tradução minha).

Assumo, desse modo, a hipótese de que, mesmo mediante os afastamentos ocasionados pela emigração, a aldeia permanece como espaço social de interesse dos agentes. A aldeia é parte constituinte do campo social transnacional, espaço alargado de relações que inclui também indivíduos que nunca cruzaram fronteiras, mas que estão ligados, por meio de relações sociais, a indivíduos situados em lugares distantes. Múltiplos agentes sustentam essa formação que atravessa fronteiras por meio das relações e trocas que efetuam continuamente, mas sobretudo por meio do retorno, de sua influência na fabricação da vida cotidiana na aldeia. Assim, ao recusar a emigração tomada como fim, acrescento que se faz necessário pensá-la como meio, mecanismo que estimula a ação social uma vez que impõe o desafio sempre renovado de reinvenção das práticas, do espaço, do tempo, da comunidade, da própria aldeia enfim.

Este capítulo se dedica a pensar a dinâmica pendular e sua duração, tendo em conta seu processo de formação e assim abrangendo os contextos variados de interação do contingente migrante. As observações realizadas em campo que baseiam as reflexões aqui expostas se deram sobretudo nos contextos de destino, nos espaços para os quais os agentes migrantes se deslocaram ao longo de suas trajetórias moventes. No entanto, ao observar a relação que os agentes estabelecem com os espaços de destino, ganharam 
relevo diversas situações em que o processo de construção de fronteiras foi revelador do aspecto das interações. Isso significa que a variação de quadros e espaços de interação ocasionou situações repletas de nuances densas de significado.

Dessa maneira, a observação das relações construídas ao longo dos trajetos migratórios passa antes pela percepção dos modos de reconfiguração das proximidades, da constituição de coletividades (mais coesas ou difusas). A proposta se próxima do que defende Igor de Renó Machado quando afirma que o intento consiste em "pensar a construção das fronteiras a partir do grupo que emigra e não em relação preponderante ao Estado e às identidades hegemônicas dos lugares de recepção dos migrantes" (2009: 182). Ao buscar um "olhar etnográfico 'de dentro' do grupo" (Idem: 183), Machado destaca uma estratégia de pesquisa que se preocupa com o modo como a emigração é significada e entendida nos termos e valores dos próprios migrantes. A etnografia se fez assim atenta às construções de modos de vida através da emigração e na imigração, bem como às conexões entre pessoas e processos.

Perseguindo trajetos e percursos, a etnografia toma forma e corpo. É na vivência cotidiana dos espaços de trabalho e sociabilidade que atuam tensões constitutivas do quadro social observado. As incertezas e descontinuidades das trajetórias sociais dos agentes apontam para filiações e conflitos que colocam em curso a fluidez das fronteiras e desafiam qualquer tentativa de esboço de contornos muito sedimentados.

São idas e vindas em virtude de fatores muito variados, de ordens bastante distintas. Cada iniciativa emigratória encontra maior ou menor relação com um grupo emigrado já estabelecido no contexto de destino e varia em sucesso no que se refere à capacidade de reprodução material e prosperidade financeira. Essas e muitas outras variáveis condicionam as possibilidades de fixação, partidas, retornos ocasionais, periódicos ou definitivos. E parte substancial da constituição dos projetos emigratórios se concentra nas projeções de retorno. É parte fundamental da dinâmica emigratória e provê de significado o deslocamento, já que é somente através dessa projeção (que independe de sua realização definitiva ${ }^{36}$ ) que a aldeia permanece como espaço de importância destacada na formação da comunidade transnacional, na rede de solidariedade e sociabilidade.

\footnotetext{
36 Na concepção de Maria Beatriz Rocha-Trindade, "em todo processo migratório que, ao longo de séculos, mostrou partidas de portugueses, afastando-os dos locais onde nasceram, se observa também a
} 
Nesse sentido, é relevante considerar que a circulação transnacional não se dá unidirecionalmente, no sentido de um afastamento que desliga, mas também no sentido do retorno, quando então fica caracterizado que a aldeia é parte decisiva desse campo social, que motiva e coloca em curso os agentes, como bem observou Caroline Brettell quando diz que "ao emigrar, migrantes portugueses estão procurando no exterior um meio de conquistar prestígio e mobilidade no interior de seu próprio sistema social" (2003:64, tradução minha).

\section{- 1.2 SOBRE O PROCESSO HISTÓRICO DA EMIGRAÇÃO EM PORTUGAL}

Este trecho do trabalho tem como objetivo específico ambientar a discussão por meio de traços genéricos da emigração em Portugal, procurando enfatizar a "grande debandada" (ROSAS, 1998: 373) que se desenha a partir da década de 1950, momento em que situo o recorte de pesquisa. Dentre os diversos interlocutores com os quais tive oportunidade de interagir em campo, alguns dos quais se dispuseram a narrar suas trajetórias, a grande maioria experimentou as primeiras tentativas emigratórias entre meados da década de 1950 e o final da década de 1980. Há também, obviamente, os mais jovens que emigraram recentemente, entre os anos 1990 e 2000, e aqueles que em meio às conversas denotam algum interesse germinal pela empreitada migratória, o que apenas indica a duração estruturada dessa prática no contexto aldeão ${ }^{37}$. No entanto, trata-se tão somente de construir aqui uma prévia de enquadramento histórico apenas como ponto de partida para uma discussão que cruza escalas do processo social e busca compreender como as tensões políticas atravessam a vida cotidiana e as trajetórias dos agentes.

multiplicidade das afirmações de desejo de regressar, das expressões de interacção forte com as raízes, mesmo quando o correspondente regresso é mais transitório do que definitivo, ou mais platônico do que consumado" (1987:722). Mantendo o retorno no horizonte de suas metas, os emigrantes sustentam um discurso velado sobre seus interesses em mudar de posição na hierarquia social da aldeia.

37 Neste ponto vale pensar na análise de Eunice Durham, segundo a qual "padrões culturais sobrevivem na medida em que persistem as situações que lhes deram origem, ou alteram seu significado para expressar novos problemas" (2004 [1976]: 230). 
Antes de tudo destaco que, ao consultar, nesse caminho, diversas fontes bibliográficas e compêndios de história de Portugal ${ }^{38}$, o século XIX surge antes como um referencial para as análises diacrônicas sobre a dinâmica emigratória no país, referencial primeiro, que antecede qualquer esforço de compreensão do impulso diaspórico da segunda metade de século XX. Não é escuso, portanto, se considerar a esse respeito que desde o final do século XIX a emigração ganha volume tanto em números absolutos quanto na atenção que recebe por parte de intelectuais e políticos. A tendência emigratória que se anuncia em Portugal "é tema, desde a segunda metade do Oitocentos, de uma ampla polémica nas esferas políticas e nos meios intelectuais. (...) 'Mal necessário' ou a 'evitar', ela tem um lugar de destaque na representação colectiva da sociedade portuguesa através da figura do emigrante" (PAULO, 2000: 62-63). Como também destaca Paulo Filipe Monteiro, "a emigração começou a ser discutida pelos intelectuais do século XIX nos quadros de uma "patologia social da nação"” (1994:1).

A esse respeito, é relevante notar como o processo emigratório passou paulatinamente a ser relacionado com a constituição do "caráter nacional" português desde o contexto de fins do XIX. Para tanto, é preciso antes passar pela objetivação do contexto nacional à época, procurando entender como se atrelou a emigração aos conteúdos elaborados para essa categoria de pensamento (do nacional). A profunda crise em que se afundava a monarquia portuguesa, processo que, apesar dos esforços relutantes da nobreza, culminaria na proclamação da república em 1910, é um elemento decisivo desse complexo momento político em Portugal. E atrelado a esse contexto associa-se um processo não menos complexo de refundação ${ }^{39}$ do imaginário associado à identidade naci-

\footnotetext{
38 A esse respeito, ver Ramos (1994), Rosas (1998), Brettell (2003), Scott (2010), Serrão (1970), Paulo (2000), Freitas (2004), Monteiro (1994), Herculano (1879) e Pereira (1982).
}

39 Rui Ramos denomina esse período de instituição do regime republicano apropriadamente de “segunda fundação". Ele se refere às disputas simbólicas concomitantes à crise da monarquia, como se a queda do regime monárquico fosse acompanhada de um lapso identitário que precisava ser fortuitamente preenchido por algo que se propusesse a "recuperar" o que há de mais "verdadeiro" no caráter nacional. Quando se refere à "invenção de Portugal", a noção de "invenção" é utilizada aqui da maneira como a elaboram Eric Hobsbawm e Terence Ranger: "Por 'tradição inventada' entende-se um conjunto de práticas (...) de natureza ritual ou simbólica, que visam inculcar certos valores e normas de comportamento através da repetição, o que implica, automaticamente, uma continuidade em relação ao passado. Aliás, sempre que possível, tenta-se estabelecer relação com um passado histórico apropriado." (HOBSBAWM e RANGER, 1997: 9). E não por acaso é nesse momento de refundação que o emigrante, em geral de 
onal em todos os seus aspectos, com o intuito de obliterar a imagética da monarquia e constituir uma nova simbologia nacional própria à república. A figura do emigrante ganha eminência como símbolo justamente nesse contexto.

Para todos os efeitos, o século XIX figura como referência de viragem qualitativa e quantitativa dos modos e índices de mobilidade populacional. Para isso deve-se notar que a eletricidade, o transporte, as viagens, as comunicações, o conhecimento, tudo isso foi inovado acentuadamente em um curto intervalo de tempo. A coexistência e correlação de inúmeras transformações no final do XIX ocasionaram uma conjuntura histórica na qual a emigração ocupa um lugar como processo que cumulou em uma nova realidade de trabalho e vivência cotidiana. Em sua avaliação histórica das transformações experimentadas pela Europa no século XIX, ao relacionar esse contexto com os fluxos migratórios portugueses e o modo como tudo isso influiu sobre a mobilidade populacional, Joel Serrão diz o seguinte:

\footnotetext{
"Na verdade, o desenvolvimento e a expansão do capitalismo industrial, a revolução do maquinismo, a profunda alteração do sistema dos transportes nacionais e internacionais devida aos caminhos de ferro, o surto das grandes concentrações urbanas, - tudo isso alterou os modos de vida tradicionais de grande parte da população da Europa Ocidental. A extraordinária mobilidade populacional que, então, se verifica, é um dos índices mais significativos das mutações por que a Europa passa. (...) A partir da $2^{\mathrm{a}}$ metade do século XIX, após a independência do Brasil, a emigração portuguesa assumiu, quantitativa e qualitativamente, aspectos inteiramente novos. (...) Torrentes humanas abandonam os campos, e dirigem-se para as cidades em vias de industrialização, ou para terras longínquas (...) no afã de uma vida nova, que se imagina coroada pelo enriquecimento breve. O século XIX alterou, demográfica e socialmente, os quadros tradicionais, e suscitou, na esfera psicológica, a vivência de necessidades novas, particularmente no atinente à promoção social e econômica" (1970: 603).
}

origem camponesa, é elevado à condição de símbolo nacional, ou, segundo Brettell, "em Portugal, o emigrante é um símbolo chave da identidade nacional" (2003: 9, tradução minha). 
Portugal se viu incluso nessa torrente de mutações e observou o processo crescente de esvaziamento do campo e modificação do modo de vida baseado na agricultura familiar. Sobretudo sua porção interior se viu confrontada com transformações significativas que alteraram as expectativas e possibilidades de realização da vida em seus aspectos mais corriqueiros. O que agravava a situação do camponês aldeão era, sobretudo, o acúmulo de crises econômicas, o que reverberava imediatamente na qualidade de vida experimentada no espaço rural.

O período republicano, no entanto, durou muito pouco. Já em 1926, António de Oliveira Salazar chega ao poder e ali se fixa numa longa e extenuante ditadura. As condições gerais que se cumulavam para gerar o quadro emigratório que se configurava desde meados do século XIX se acentuaram. O século XIX introduziu uma problemática para a história recente de Portugal, atrelada a causas de ordem geral, de crise econômica e de transformações sociopolíticas. Esse momento da história portuguesa pode ser recortado como o primeiro grande ímpeto diaspórico de uma torrente emigratória que, em verdade, nunca cessa de fato. $\mathrm{O}$ século XX, contudo, traz consigo mudanças significativas na constituição dos fluxos migratórios em Portugal, sobretudo mediante a crise do primeiro período republicano, a partir da instauração do regime ditatorial conhecido como Estado Novo (1933-1974).

O período ditatorial salazarista introduziu nesse quadro elementos decisivos para a configuração da dinâmica emigratória. Se começarmos a contabilizar pelo aspecto ideológico, é imprescindível ressaltar a ascensão definitiva do camponês à centralidade da simbologia da identidade nacional. O regime que se configurou então em Portugal sob o comando de António de Oliveira Salazar imprimiu diretrizes, sobretudo ideológicas, que acentuaram o trabalho de "invenção das tradições": "o salazarismo vai, desta forma, ampliar a recuperação, já desenvolvida pelos republicanos, de um dos traços mais familiares ao emigrante, ou seja, o dos valores da chamada 'cultura popular'" (PAULO, 2000: 23). Salazar, portanto, trabalhou com bastante acuidade os traços da identidade que logrou atrelar a uma tradição peculiarmente "inventada". Salazar recupera elementos do universo rural para produzir o "nacional" como referência à memória do emigrante.

O discurso do regime, além de exaltar o camponês pela evocação de uma espécie de natureza ou essência, arraigada numa imagem bucólica e mítica de Portugal, o associava a uma espécie de vocação nacional para se erigir a despeito da modernização 
40. Esse discurso de certo modo conservador dava bases ideológicas para justificar a tardia e deficitária industrialização portuguesa, bem como as condições de vida do trabalhador rural. No entanto, não era capaz de uma adesão generalizada e irrestrita. Muito pelo contrário, enfrentou como consequência imprevista a emigração maciça. A política cultural de elaboração do camponês como português ideal encontrou seu limite na emigração, na medida em que os migrantes (em sua maioria de origem rural, camponesa) passaram a destinar-se em grande medida às metrópoles europeias. A emigração, portanto, foi um desafio ao nacionalismo do regime e precisava ser integrada satisfatoriamente em seu projeto e no discurso.

No entanto, mais do que enfrentar ou criminalizar a emigração, os intentos se concentravam em incorporá-la em um modelo de nação imaginada de modo descontínuo. Segundo Brettell, "nos termos de Benedict Anderson, o emigrante é o veículo para a "comunidade imaginada" portuguesa" (2003: 9, tradução minha). Embora a emigração fosse oficialmente controlada durante a maior parte do regime e a emigração ilegal punida com a prisão, "o Estado nunca atuou rigorosamente sobre a questão da emigração clandestina" (Idem: 13), ou seja, lidava de modo mais ou menos frouxo com a saída ilegal da população. No aspecto estrategicamente ideológico, isso significou a inclusão do emigrante no projeto nacionalista ao passo que o regime reconheceu nele um passado camponês e, por mais contraditório que pareça, uma fonte importante de renda (os anos sucessivos de emigração confirmaram uma tendência de remessa de dinheiro dos migrantes para os familiares que permaneceram). Conforme Heloísa Paulo, "o salazarismo é, pois, uma fórmula que encaminha o país em direcção à modernidade, vivenciada pelo emigrante nos grandes centros urbanos onde está fixado, sem alterar o "espírito" da vida aldeã, aquela que o emigrante "sublima" na sua memória" (2000:56).

A título de exemplo, é válido lembrar o concurso promovido em 1938 pelo Secretariado de Propaganda Nacional (SPN) para eleger "A aldeia mais portuguesa de Portugal". Os critérios de seleção do concurso são reveladores de quais eram as diretrizes do regime para formular as imagens do nacional baseadas no universo rural pensado como idílico e reduto do que há de mais autêntico no caráter nacional português. A esse respeito ver Alves, 2007a e Brito, 1982. Ainda sobre esse tema Pedro Félix diz o seguinte: "o concurso (...) bianual pretendia celebrar "a aldeia do território continental que maior resistência (tivesse) oferecia(do) a decomposições e influências estranhas e (apresentasse) o mais elevado estado de conservação no mais elevado grau de pureza (numa série de) características definidas no regulamento (...)". Este organismo trabalhou com imagens do país e dos portugueses que vigoravam já desde a segunda metade do século XIX, agora adaptadas ao programa do Estado Novo" (FÉLIX, 2003: 207-209). 
Assim, foi com vistas à confecção de um nacionalismo que pudesse assegurar uma linha de continuidade entre o passado histórico apropriadamente requisitado e o presente refratário, emigrante, que o regime ditatorial salazarista elaborou seu discurso sobre a emigração. O emigrante passou a ser parte de um discurso que o incluía, que se firmava sobre a ideia de uma nação vocacionada para a conquista e que por isso se espalhava pelo mundo. Nas palavras de Caroline Cotta de Mello Freitas

\begin{abstract}
"Esta imagem da nação-Império desterritorializada tem como um de seus alvos o emigrante português. O salazarismo, ao identificar o emigrante português como o representante da imagem da nação, como o mantenedor da tradição expansionista portuguesa, por entender a emigração como "um destino do povo português", confere ao migrante o estatuto de exemplo do que é ser português" (2004: 63)
\end{abstract}

O emigrante de origem camponesa adquire a centralidade das representações da nação e passa a ser incluído no projeto salazarista de nação em que a emigração passa a ser tomada como um ato patriótico que, ademais, cumpre a função de levar para terras longínquas os valores e o ideário português. Sapiente das eminentes origens populares e rurais do emigrante, traços essencializados dessa característica são exaltados. Por essa via o camponês, ainda que emigre, continua a figurar no centro das representações ideal-típicas da identidade nacional. Conforme afirma Heloísa Paulo "o "português", transfigurado em determinados estereótipos regionais, é identificado com uma visão idílica do universo rural" (2000: 44).

Toda política cultural elaborada pelo Secretariado Nacional da Informação, Cultura Popular e Turismo (SNI) ${ }^{41}$ voltada para o emigrante tinha como intuito inspirar unidade, mesmo diante dos afastamentos migratórios. Ou seja, a propaganda endereçada ao emigrante pretendia incutir-lhe as sensações de pertencimento e participação. Ao suscitar na memória do emigrante a nostalgia da aldeia, o salazarismo pretendia realizar

\footnotetext{
41 A partir de 1945 o SPN passou a chamar-se Secretariado Nacional da Informação, Cultura Popular e Turismo (SNI). Era o órgão de censura e propaganda do regime. A forma de atuação permaneceu fundamentalmente a mesma, com alterações que visavam à adequação ao novo cenário político internacional originado após o fim da II Guerra Mundial e derrocada de regimes totalitários.
} 
uma imediata associação entre o sentimento de pertença local e o patriotismo. Nesse sentido, "Portugal é apresentado como uma grande aldeia" (Idem: 50) e o emigrante como seu representante heroico, aquele responsável por transferir "para o presente a "predestinação" colonizadora da época dos descobrimentos" (Ibidem: 54).

Concomitantemente, a grave crise política e econômica a que o regime ditatorial levou o país, sobretudo após a II Guerra Mundial, precedeu o segundo marco de extrema relevância para a abordagem da emigração portuguesa (o período do segundo grande impulso diaspórico). As décadas que se seguiram ao fim da guerra podem ser encaradas como o período de maior intensidade de saída de migrantes, momento que consolidou a diáspora portuguesa. Ana Silvia Scott apresenta os seguintes dados comparativos: "Entre 1886 e 1960, saíram de Portugal mais de um milhão e meio de emigrantes. Isso não é nada se comparado à saída de outro milhão e meio (pelo menos) de portugueses no curtíssimo período dos anos 1960 e 1970” (2010: 148).

A conjuntura externa que envolveu o período salazarista, por sua vez, teve grande influência na acentuação do trânsito migratório na segunda metade do século XX. Enquanto a primeira metade do século esteve comprometida por guerras de consequências terríveis para a economia portuguesa, a condição social do camponês em Portugal só piorava. A guerra gerou custos sociais vultosos, principalmente frente à derrota dos totalitarismos (o salazarismo entre eles). O severo fechamento econômico promovido durante o período da II Guerra Mundial foi sucedido por uma saída emigratória proporcionalmente intensa e que cresceu acompanhada pela lenta e gradual abertura política do salazarismo no pós-guerra. Saídas legais e ilegais avolumaram a percepção de que o regime seria incapaz de conter a pressão emigratória populacional.

Ainda há que se considerar nesse período outro fator que intensificou a pressão emigratória e se somou à fome e à escassez que viveu a população da porção rural do país: aos anos de penúria da grande guerra se sucedeu um período que agravou as condições ruins da vida no campo, já que na década de $1960{ }^{42}$ emergiram com força inúmeros movimentos independentistas nas então colônias portuguesas na África que pas-

42 Fernando Rosas, ao analisar a década de 1960 diz o seguinte: "Trata-se de uma década profundamente afectada pelas guerras coloniais em África, cujos efeitos não têm reflexos visíveis na mortalidade, mas que, juntamente com a procura de mão-de-obra em França e na Alemanha, determinam uma emigração maciça para além-Pirenéus" (ROSAS, 1998: 371). 
saram a ser combatidos por Portugal que sustentava naquele momento um imenso aparato nos territórios de seu domínio no continente africano, vendo-se por isso obrigado a alimentar guerras para assegurar a manutenção de seu território colonial ${ }^{43}$. João Baptista Pereira, por exemplo, aponta para uma relação interessante entre guerras coloniais e emigração em Portugal:

"Não se pode desprezar a hipótese de uma relação direta entre o incremento da emigração ao redor de 1963 e os reflexos da guerra colonial (Angola), em 1966. (...) A guerra colonial fez com que a própria emigração se constituísse numa forma honrosa de a geração jovem, em idade militar, escapar da convocação" (1982:143, notas)

Nesse ponto abordo mais propriamente o recorte de pesquisa e começam a ficar claros os modos de imbricação entre as trajetórias de sujeitos que colaboraram na construção desta pesquisa e os contextos políticos mais amplos reconstituídos aqui brevemente. Diversas trajetórias que conheci durante o trabalho de campo narram, de um modo ou de outro, alguma forma de relação entre as escolhas individuais e a situação política de Portugal ante as guerras coloniais.

$$
\text { *** }
$$

Com base nas experiências vividas durante o trabalho de campo percebi que muitas trajetórias migrantes são entremeadas ao contexto das guerras coloniais portuguesas. Ou seja, diversas trajetórias foram constituídas e construídas em relação ao momento histórico das descolonizações africanas. Muitas decisões foram tomadas, ações executadas e estratégias de deslocamentos foram contextualmente pensadas, me-

43 Ana Silvia Scott explica a esse respeito que "as causas internas que levaram ao êxodo generalizado têm raízes na pobreza estrutural que vivia a maior parte da população, mas [também] na conjuntura de crise social e política do Estado Novo somada à guerra colonial mantida nos territórios africanos" (2010: 152). 
diante os condicionantes e possibilidades que a complexa situação conjugava. Uma vez mais, portanto, somos levados, pela articulação de elementos de relevância significativa, a pensar um plano articulado entre contexto e agência.

Para tratar mais detida e detalhadamente algumas trajetórias que ajudarão a construir os quadros posteriores de análise etnográfica, é importante ainda recorrer a aspectos históricos de destaque do momento referido. O grande impulso emigratório das décadas de 1960 e 1970 representou para as estatísticas emigratórias em Portugal um ponto de inflexão importante, já que significou, entre outras coisas, a reconversão de tendências e direções de fluxo. Se até a década de 1950 a emigração para o Brasil recebia destaque, já nessa mesma década se anuncia a mudança de rumos das correntes emigratórias frente às demandas criadas nos demais países europeus nos anos de reconstrução após a guerra.

Conforme assinala Scott, "o fluxo migratório dos anos 1960 e 1970 era bem diferente do tradicional, dirigido ao Brasil. Destinava-se, naquele momento, aos países industrializados da Europa Ocidental, quando milhares de portugueses foram recrutados (...) para alimentar a florescente economia do pós-guerra" (2010:149-150). Ou seja, a emigração portuguesa passou a ocorrer majoritariamente para outros países europeus, o que facilitou a constância dos retornos. Os principais destinos eram os países europeus vizinhos que estavam se reindustrializando, sobretudo a França. Silvia Scott também nota esse aspecto ao afirmar que "a guinada do movimento migratório em direção aos países europeus (França, Alemanha, Suíça) facilitou o trânsito mais regular entre a terra de origem e a de acolhimento. Nos feriados ou nas férias de verão, os emigrantes aproveitavam para visitar Portugal" (Idem:153). Por esse meio, a contínua remarcação da pertença tornou-se um vetor da nova dinâmica migratória, já que para o emigrante colocou-se a possibilidade de nutrir o pertencimento com a participação assídua na vida social do seu contexto de origem. É a essa modalidade de retorno engendrado nas condições históricas e sociais aqui descritas que pretendo me referir etnograficamente adiante, em momento apropriado da discussão.

Assim, com respeito às estratégias migratórias e às contingências que as configuraram no contexto de fins do império colonial português, é possível dizer que precisam ser pensadas conjunta e relacionalmente. Grande parte do contingente migrante jovem masculino optava por iniciar um percurso migratório porque assim poderia esquivar-se do alistamento militar obrigatório e, muito provavelmente, de ser 
enviado para o combate em solo africano. Conforme assinala Caroline Brettell referindo-se primeiramente à tendência emigratória para o Brasil de fins do século XIX e começo do XX para, por fim, compará-la aos motivos da emigração já no começo da década de 1960: “[aos] motivos económicos acrescentava-se o desejo de escapar à tropa, motivo que aliás voltou a desempenhar um papel importante na emigração maciça para a França posterior a 1961" (1991: 96).

Outra grande parte dos migrantes era justamente por meio do alistamento que iniciava seus deslocamentos. Muitos começaram a emigrar após terem sido enviados para algum país africano no exército ou na marinha. Depois de algum tempo de serviço militar, dificilmente voltavam a se estabelecer nas aldeias de origem, iniciando assim uma série de movimentos antes de encontrar um lugar em que conseguissem se estabelecer. Outros, no entanto, acabavam partindo motivados por incentivos criados pelo Estado Novo para ocupar os territórios do domínio colonial no continente africano $^{44}$.

Não é raro, portanto, encontrar em Vilas Boas alguém que tenha tido vivências relacionadas a alguma guerra colonial. E é comum que essa experiência se torne um referencial mnêmico. No trecho a seguir passo a pensar a emigração a partir de exemplos etnográficos que, além de apontarem o enredamento das trajetórias individuais com os grandes eventos da história nacional, delimitam as configurações locais da emigração.

\footnotetext{
$44 \quad$ O projeto de povoamento das colônias africanas, colocado em curso já bem antes da década de 1960, tinha o intuito de evitar as independências e reproduzir alhures um modelo de sociedade de feitio rural por meio do envio de camponeses para constituir na África unidades inspiradas num estereótipo acerca da aldeia portuguesa. Nesse momento o discurso do regime muda sensivelmente, e passa a denominar os territórios ultramarinos não mais apenas como colônias, mas como extensões das fronteiras nacionais. "O objetivo era a preservação de um núcleo de povoamento genuinamente português, de modo a assegurar a 'nacionalização' do território. E para isso, nada melhor do que reproduzir aí um mundo rural de pequenos proprietários, vivendo em comunidades homogéneas e auto-suficientes, como se imaginava que originalmente tenha sido o dos antepassados lusitanos” (RAMOS, $2003: 422$ ).
} 


\section{- 1.3 ESBOÇO DE HISTÓRICO DA EMIGRAÇÃO EM VILAS BOAS POR MEIO DE SEUS AGENTES, OU DOS RASTROS DE EMIGRAÇÃO}

\section{Muitos destinos, algumas tendências: Angola e Brasil, Espanha e França}

É importante reforçar neste ponto que a recuperação de contextos históricos mais amplos até aqui empreendida tem como objetivo ajudar a delinear as configurações locais do processo emigratório. Assim, a inserção de contextos históricos na organização do texto realiza uma função lógica de fazer emergirem os modos pelos quais as trajetórias dos sujeitos interlocutores estão intimamente relacionadas com configurações mais amplas, de guerras coloniais e do período pós-colonial de Portugal. A partir desse ponto, contudo, a ênfase recai sobre a dimensão local. E é relevante notar de antemão que no caso de Vilas Boas não é raro encontrar alguém que tenha tido vivências relacionadas a alguma situação decorrente do colonialismo em seu momento derradeiro.

Lembro que pouco depois que cheguei à aldeia e comecei a circular, passei a ser apresentado pelos meus interlocutores mais constantes às pessoas que ali já estavam. Assim aos poucos eu passava a conhecer e reconhecer agentes locais e, do mesmo modo, ser por eles reconhecido. Em uma dessas ocasiões, por exemplo, conheci Joaquim, primo de Damião, e pudemos conversar informalmente por um bom tempo, em uma mesa do "Café de Cima" ${ }^{45}$. Ao saber que eu estava ali com propósitos de pesquisa, Joaquim escolheu contar algo de sua trajetória pessoal que considerou relevante em vista do que pude lhe explicar sobre a pesquisa. Sua narrativa foi um tanto panorâmica, mas bastante reveladora, como entrada para a pesquisa de campo, dos modos pelos quais trajetórias envoltas em quadros locais se relacionam e articulam a fatores externos de diversas ordens.

45 Os "Cafés" (grafados aqui sempre com letra inicial maiúscula) são estabelecimentos comerciais que negociam todo tipo de produtos para consumo imediato tais como cigarros, aperitivos e bebidas, além de oferecer divertimento com jogos de carteado, entre outros. Tratarei desse espaço com maior detalhe em outro momento do texto. O trabalho de campo fez perceber que nos Cafés se passa muito do que é significativo para o processo social enfocado na pesquisa. Espaço de sociabilidade, os Cafés ocupam lugar de destaque no escopo da pesquisa de campo e são reveladores de vínculos e conflitos, condensam situações específicas de interação que colocam em ação diversos aspectos das relações construídas. Para uma aproximação analítica do contexto dos Café em Portugal, conferir Almeida, 2000 e Frúgoli Jr., 2013. 
Quando optou por narrar as tortuosidades de seu percurso migratório, Joaquim começou explicando que emigrou pela primeira vez muito jovem. Seu pai havia se engajado nas campanhas do governo salazarista que enviaram colonos para o território africano. Já em meados da década de 1950, quando era ainda apenas uma criança de colo, Joaquim e sua família emigraram para Angola. Segundo Joaquim, seu pai havia se tornado supervisor de um colonato ${ }^{46}$. Por volta de 1961, no entanto, o pai de Joaquim teve que voltar a Portugal em busca de tratamento médico para suas fortes dores nas costas, decorrentes de hérnias. Joaquim também retornou nessa mesma ocasião e permaneceu em Portugal por cerca de três anos, até 1964, quando então voltou a emigrar, mas dessa vez sozinho. Tinha em torno de quatorze anos (não soube ser preciso sobre sua idade na data da viagem) e foi mais uma vez para a África, a Luanda, onde tinha uma irmã trinta anos mais velha, proprietária de uma pensão. Foi nessa época que fez seus primeiros estudos para trabalhar como eletricista.

Joaquim lembrou então que, logo que chegou o ano de 1975 ele e seus familiares foram obrigados a voltar para Portugal em virtude da independência de Angola. Ele, no entanto, diferentemente de seus pais, já idosos, não voltou à aldeia (como no caso de seu primeiro retorno, ainda criança). Foi direto para Lisboa, onde se fixou, aprimorou e exerceu suas aptidões como eletricista.

Ele não foi muito detalhista a respeito da vida que levou em Lisboa. Citou apenas brevemente que trabalhou parte desse período como empregado, mas que depois de algum tempo abriu sua própria empresa. Atualmente Joaquim está aposentado e deu bastante destaque em sua narrativa às suas atividades no presente. Disse que vive em Lisboa, mas que já há algum tempo tem vindo a Vilas Boas diversas vezes ao longo do ano, sobretudo em feriados religiosos. Isso porque, segundo ele, depois que seu pai faleceu, tem se dedicado a reformar a casa que herdou.

Ademais, dados seus conhecimentos como eletricista, tem se engajado há alguns anos em ajudar na preparação das festividades de agosto, produzindo uma decoração

\footnotetext{
46 Colonatos eram as unidades de povoamento instaladas no território das colônias portuguesas na África. Os supervisores dos colonatos eram responsáveis por verificar as carências do povoamento instalado, atuando como intermediários entre colonos e burocracia, e realizando a listagem e pedidos de itens faltantes, tais como água, sementes e materiais de trabalho, tais como ferramentas (RAMOS, 2003; CASTELO, 2007).
} 
luminosa para o santuário de Nossa Senhora da Assunção ${ }^{47}$, em torno do qual giram as celebrações que reúnem os emigrantes. No instante em que contou de sua participação na preparação da festa, apontou para a igreja, sempre visível, como já mencionado, no alto do morro situado ao lado do núcleo habitado da aldeia. Era começo da noite e a iluminação festiva estava acesa, dando destaque ao santuário de traços barrocos em meio ao breu dos montes repletos de bosques de coníferas, parreiras e olivais. Acrescentou ainda que seu trabalho não estava pronto, e que nos próximos dias o santuário estaria ainda mais iluminado para receber a festa e a romaria.

A história pessoal narrada por Joaquim de modo bastante informal numa espécie de entrevista fortuita e aberta apresenta, por sua vez, diversos elementos significativos para a pesquisa. Se fracionada e tomada como trajetória ${ }^{48}$ a partir dos traços pertinentes que suscita, essa interação breve no trabalho de campo permitiu, entre outras coisas, construir indícios fortes a respeito da emigração no plano local. Joaquim foi bem claro quando terminou sua fala ao dizer que não tinha nada mais para relatar que pudesse ajudar. Eu sabia que, de fato, meu interlocutor mais perene seria Damião, com quem eu havia construído uma relação de interlocução e diálogo mais densa e intensa. No entan-

47 Como já dito, o referido santuário fica nos entornos da aldeia e é o destino de uma grande romaria no mês de agosto, quando acontece a festa popular em homenagem à sua padroeira, Nossa Senhora da Assunção, em memória e homenagem aos milagres realizados no mesmo monte em que ele se fixa. Essa é a principal festa popular da freguesia e é em torno dela que se concentram motivos diversos para o retorno dos emigrantes provenientes de Vilas Boas. Tratarei do tema no quarto capítulo, quando discuto o contexto de retorno e a participação dos emigrantes nas festividades.

48 Trajetórias são construções que o pesquisador obtém como resultado de seu trabalho de escrutinização dos "traços pertinentes" de um grupo de biografias. Por "traços pertinentes" entendo aqueles capazes de descrever investimentos nos termos do capital simbólico socialmente valorizado (que movimenta a disputa, as estratégias de acumulação no campo considerado; no caso aqui discutido, penso no campo social transnacional). Na medida em que se realizam no espaço dos possíveis, nas trajetórias estão marcadas as linhas de força que operam na configuração do campo segundo um corte sincrônico (porque o campo é sempre uma formação histórica, inacabado, e que pode ser apreendido em seu movimento segundo a delimitação sincrônica estabelecida pelo observador/pesquisador). A percepção do processo histórico de constituição de um campo social envolve sobremaneira a compreensão dos modos pelos quais as trajetórias individuais são, em grande medida, constitutivas de uma trajetória do grupo, coletiva. Como destaca Miguel Montagner, é importante "acompanhar o desenrolar histórico de grupos sociais concretos em um espaço social definido por esses mesmos grupos em suas batalhas pela definição dos limites e da legitimidade dentro do campo em que se inserem" (2007: 257). 
to, o que Joaquim aceitou dizer nos apresenta um exemplo adicional de características presentes também em outras trajetórias.

Damião, por exemplo, entre as muitas e longas conversas que tivemos, confessou algumas vezes que, embora tenha emigrado pela primeira vez ainda criança, na companhia de seu pai, terminou por escolher não retornar a Portugal como forma de evitar o risco de ser recrutado para as guerras coloniais. Por volta dos seus dezesseis anos de idade passou a fronteira a salto $^{49} \mathrm{com}$ um grupo de colegas da mesma idade e da mesma aldeia, prenhe do receio de ser pego pela vigilância na fronteira com a Espanha (como havia já acontecido com alguns conhecidos seus e outros sobre os quais tinha ouvido falar). Ademais, sua trajetória percorreu também diversos destinos antes de ele poder se fixar em Bembibre, na Espanha, onde exerceu por mais de um par de décadas a mineração de carvão.

Já André, por sua parte, depois de ter realizado serviço militar obrigatório em Lisboa e de ter servido por alguns anos a marinha portuguesa já na década de 1980, tentou se fixar na capital portuguesa, mas logo decidiu ir para a França e lá transitou entre empregos, bairros e patrões até conseguir estabilidade e poder então construir um conjunto de relações de convivência, comensalidade e sociabilidade em Goussainville, um bairro no subúrbio de Paris.

Cruzar a fronteira a salto é uma denominação nativa acerca do modo ilegal de emigrar. Durante quase todo o regime salazarista o controle sobre a emigração fez com que grande parte das empreitadas se desse de modo clandestino. Apesar da relativa frouxidão na fiscalização, os riscos de uma prisão ainda existiam e eram extremamente temidos. Famílias ou às vezes grupos diversificados dividiam os custos dessa empreitada, dentre os quais contabilizavam não apenas o transporte, mas principalmente os referentes aos honorários de um "passador", figura presente nas histórias de vida da quase totalidade daqueles que emigraram clandestinamente. José Portela e Sílvia Nobre afirmam que "a emigração clandestina, sobretudo para a França e em particular entre 1960 e 1974, foi parte muito significativa do volume global da emigração portuguesa" (2001: 1111). Além do mais, "esta economia era bem traduzida nas redes de engajadores-passadores, que promoviam o recrutamento, transporte, transbordo e, por vezes, alojamento inicial e ocupação de "emigrantes clandestinos"' (Idem). O passador era alguém responsável por auxiliar um sujeito ou grupo de pessoas a cruzar a fronteira, e que era possuidor de um imenso saber prático acerca das estratégias adequadas para cruzar ilegalmente a divisa do país com a Espanha. A respeito da experiência de cruzar a fronteira a salto é importante ainda citar o filme "O Salto", de 1967, do diretor Christian de Chalonge. O longa metragem narra as dificuldades do protagonista para cruzar as fronteiras até chegar à França ilegalmente, bem como os problemas enfrentados no destino. 
Diante desses por enquanto breves exemplos gerais, os traços biográficos que se destacam são aqueles que ajudam a constituir algo de uma trajetória coletiva ou ainda de uma história local da emigração. Lidamos aqui com percursos incertos quanto a seus trajetos, construídos a cada escolha e mediante uma série de contextos e contingências. É importante notar, a título de reflexão, que conquistar uma situação estável de trabalho e moradia nos contextos de destino custa bastante tempo e esforço. Muitas vezes esse momento nunca chega.

Ademais, é frente aos percursos desses agentes que podemos conhecer tendências locais específicas de trajetos e a constituição de polos de destinos emigratórios nos âmbitos do campo transnacional em formação. Tal como delineado por alto no trecho anterior, quando então foi traçado um perfil da emigração portuguesa, esse processo social que perdura no tempo (obviamente nem sempre o mesmo, mas repleto de transformações contextuais) teve momentos e tendências variadas em diferentes escalas. E não é regra que as tendências observadas nacionalmente sejam refletidas localmente. Procuro observar agora, portanto, de um ponto de vista que se coloca entre o grupo migrante, as tendências ou "ciclos" que se formaram localmente, elegendo determinadas localidades como destinos preferenciais em certos períodos ou para determinadas gerações.

A emigração, o plano local e a constituição de alguns destinos como polos: o uso de entrevistas na reconstituição de algumas trajetórias

A partir daqui analiso mais especificamente os anos de virada da emigração portuguesa para dentro do continente europeu. Aqui passa a ficar mais bem explicada a constituição e conformação da dinâmica regular de deslocamentos, já que destinos mais próximos passaram a significar retornos mais constantes e participações mais regulares na vida social da aldeia. A emergência do processo de circulação sazonal aparece entremeada a elementos significativos da cultura portuguesa, tais como as festas populares de verão e as identidades locais (aldeãs). Para tanto, realizo grande esforço para inventariar um histórico local da emigração, destacando os trajetos de alguns colaboradoreschave às escolhas datadas pela emigração para a Espanha e a França como destinos tipi- 
ficados para algumas gerações. A ideia é ter uma percepção ampla da emigração local por meio de algumas trajetórias de agentes locais.

Enquanto estive empenhado na realização de entrevistas ${ }^{50}$ durante o trabalho de campo, tive oportunidade de conhecer ainda algumas poucas pessoas que fizeram parte do momento em que o Brasil era o destino preferido dos emigrantes. Foi sobretudo a partir da década de 1950 que a tendência emigratória se redirecionou e redimensionou, tornando cada vez mais o Brasil um destino menos atraente em detrimento dos países vizinhos europeus, mais próximos e repletos de possibilidades oferecidas pelo momento desenvolvimentista ocasionado pela reconstrução após a segunda grande guerra mundial. No entanto, por muitos anos o Brasil permaneceu ainda como opção eventualmente cogitada, remotamente aventada. O irmão de Joaquim, por exemplo (que ele citou durante a descrição de sua história de vida, mas que não cheguei a conhecer), tentou já na segunda metade dos anos 1970 se estabelecer no Brasil, de onde enviaria notícias para que Joaquim avaliasse se deveria tomar o mesmo rumo. A avaliação do irmão de Joaquim, no entanto, foi bastante negativa sobre o contexto brasileiro, o que redundou na desistência de ambos de ali se instalarem.

Há, além desse, outros exemplos esparsos de pessoas que passaram ou se fixaram no Brasil mesmo depois da década de 1950. A senhora Mabel (76 anos), por exemplo, que entrevistei e pude acompanhar em algumas situações, teve trajetória migrante que principiou passando por Angola em 1966, em companhia da família de seu então marido, que também havia para lá rumado com ajuda do regime de Salazar. Trabalhou por alguns anos no comércio da família, mas retornou a Portugal pouco antes da independência de Angola, já no começo da década de 1970. De volta a Portugal, trabalhou ainda alguns anos com a agricultura, mas em 1973 emigrou para o Brasil, motivada pela ajuda prometida pelos irmãos e irmãs de seu marido, estabelecidos anteriormente em território brasileiro. Mabel permaneceu no Brasil até 1991 e, após ter se divorciado, viveu ainda um tempo em Poços de Caldas (Minas Gerais, Brasil), mas decidiu por fim

\footnotetext{
50 Para compreender a relação que se desenvolve durante a entrevista é possível recordar Ruth Cardoso quando a define como "forma de comunicação entre duas pessoas que estão procurando entendimento. Ambos aprendem, se aborrecem, se divertem e o discurso é modulado por tudo isso" (1988:102). A partir dessa perspectiva é possível conceber o uso complementar da entrevista como forma acessória de construção dos dados, encetada por meio de inúmeras mediações construídas na duração da observação etnográfica.
} 
retornar a Portugal onde, segundo ela, poderia estar mais próxima de suas filhas e netos. No período de sua emigração para o Brasil trabalhou em oficinas de costura durante a maior parte do tempo, ofício que continuou realizando em Portugal, mesmo aposentada, como forma de complementar sua renda. Diante desse percurso emigratório de ampla circulação, é importante notar o aspecto familiar da empreitada emigratória. Os deslocamentos de Mabel estiveram sempre de alguma forma associados à família de seu exmarido (Angola e Brasil) ou a suas filhas (seu retorno definitivo). Desse modo, o Brasil continuou figurando como possibilidade emigratória mesmo após a viragem da década de 1950, isso mediante configurações complexas e estratégias familiares dos agentes, que avaliavam essa possibilidade com referência à estrutura familiar de acolhimento no contexto de destino.

No entanto, é gritante que o fato sociológica e estatisticamente relevante se situa no fluxo que se organizou a partir daquele momento para o interior da Europa. Como foi dito acima, a emigração desde a década de 1950 havia se reorientado para o interior europeu e foi a partir de então que a França começou a adquirir destaque amplo. Em pouco tempo se tornou o principal destino do contingente migrante, de tal modo que atualmente o terceiro maior grupo emigrante em território francês é português ${ }^{51}$, sem dúvida um número expressivo, considerando a soma dos emigrantes e de seus descendentes imediatos, mesmo que nascidos em território francês.

Essa tendência percebida é um tanto mais significativa para o recorte temporal aqui proposto. De fato, alguns dos anciãos da aldeia que pude entrevistar narraram percursos incertos que muitas das vezes não chegavam a produzir uma fixação definitiva para o migrante que, em certos casos, não sustentava sequer uma permanência prolongada no país de destino. Empreitadas de longa duração são eventos buscados em trajetórias emigratórias, mas que em geral dependem de tentativas repetidas e sucessivas, além de uma combinação complexa de condições para a fixação do migrante. Diante disso se abriu a possibilidade de interação com os anciãos da aldeia como forma de apreender algumas trajetórias sedimentadas e por vezes referenciadas pelos demais emigrantes. Tidos como pioneiros da geração que rumou Europa adentro, o uso de entrevistas e ob-

\footnotetext{
51 Atrás somente dos contingentes argelino e marroquino, que se originaram mais ou menos no mesmo contexto que o português (pós-colonial), mas que perduraram de modo intenso por mais tempo. (Cf. "Fiches Tématiques. Population Immigrée", Institute National de la Statistique et des Études Économiques (Insee), France, 2012).
} 
servação com grupos que emigraram a partir da década de 1960 foi decisiva para compor um quadro inicial desse contexto da emigração, em grande parte clandestina, marcado pelas tensões políticas que envolviam os projetos pessoais e familiares de cruzar fronteiras nacionais.

Nesse quadro, o senhor Clóvis (81 anos) e a senhora Brigite (77 anos) foram apontados por outros emigrantes como referências importantes. São comumente lembrados como alguns dos primeiros a arriscarem uma trajetória até então bastante incomum ${ }^{52}$. São, portanto, um casal que emigrou para a França quando, ao menos para Vilas Boas, havia apenas um conjunto muito pequeno de referências que pudesse nortear de modo mais sólido o percurso. A estrutura de relações de acolhimento estabelecida pelas emigrações prévias era ainda bastante restrita. Brigite contou que, antes de partir, ela e Clóvis, recém-casados, não eram proprietários de terra em Portugal. Conseguiam sua renda por meio de tarefas relacionadas à agricultura em geral, trabalhando para terceiros, mas sobretudo a prática de pastoreio que seu marido exercia. Clóvis cuidava do rebanho de ovelhas e das propriedades de um parente próximo.

Brigite e Clóvis foram viver em Vilas Boas após o casamento (ela aos 24 anos, ele aos 28), perto da casa da avó de seu marido, de quem Brigite cuidou por dois anos, até que a senhora idosa morresse. Antes viveram em Meireles, aldeia menor, pertencente à mesma freguesia. Segundo Brigite, naquela época ela e seu marido estavam bem porque os avós de seu marido tinham prédios onde eles produziam (sobretudo azeite, vinho e batatas, itens fundamentais da dieta alimentar). Clóvis cuidava também das propriedades de um tio seu que vivia em Lisboa e que vinha à aldeia sempre no período da vindima (colheita da uva) para acompanhar de perto o trato de suas plantações. Em 1968 finalmente decidiram ir para a França, quando Brigite contava já com 34 anos. Segundo ela, isso se deu porque tinha irmãs que já haviam lá se instalado desde 1964 e que "faziam propaganda" e pediam sua presença na França. Segue transcrição de trecho da entrevista bastante relevante a respeito:

\footnotetext{
52 Lembro-me de que Inácio (48 anos) e também meu pai (56 anos) narraram algumas vezes lembranças de infância que descrevem como eles e outros ficaram fascinados quando Clóvis, mesmo analfabeto e tendo sido sempre pastor de ovelhas em Portugal, voltou da França dirigindo um automóvel Mercedes-Benz. Tudo aquilo era assim tão fabuloso para eles porque, segundo afirmam, era bastante raro naquela época ver um automóvel na aldeia. Os únicos das proximidades pertenciam aos poucos ricos da região, proprietários de terras e dos comércios locais.
} 
Pesquisador: - Mas era muito difícil ir para lá naquela altura, não?

Sra. Brigite: - Era difícil! A primeira vez que meu marido foi para a França... foi por salto ${ }^{53}$, sabes? Mas ele não queria muito ir por conta dos prédios do tio dele. Meu pai, que já lá estava, disse: - "Que venha cá um genro acompanhar-me!” A primeira vez que foram, a guarda prendeu-os (Clóvis e os cunhados). Estiveram dois ou três dias presos e depois tiveram que pagar uma multa para sair. A minha mãe e as minhas irmãs tiveram de pedir dinheiro emprestado a uma pessoa para pagarem a carreira ${ }^{54}$ e cá tornarem. Isto foi em maio. Tinham ainda que responder [judicialmente] por irem embora da nação. Antes era assim, com o Salazar. Mas antes que respondessem, os meus cunhados tornaram cá mandar um passador buscá-los, coitadinhos. Cá passei uma noite em nervos, eles foram-se embora e... passaram bem. Foram no princípio de julho meu marido e minha filha, e no mesmo dia ele foi trabalhar, porque já tinha lá quem lhe tivesse arranjado. Ora, isto foi em 1968. Trabalhou lá vinte e dois anos, sempre no mesmo patrão, vivemos sempre na mesma vila e ainda estamos lá hoje. Primeiro, o meu cunhado arrendou-nos uma casa lá, próxima à dele. Depois de dois anos mudamo-nos ainda algumas vezes e por fim compramos uma casa grande na vila e ainda lá a temos. Tenho lá filhos. Levei cinco filhos daqui, nasceram lá mais cinco. Um morreu pequenino, nasceu em 1972 e morreu em 1973, com a coqueluche. Depois mais tarde, outro Deus levou já tinha dezesseis anos. Tinha uma moto que o pai lhe comprou e, ao ir a outra vila, um carro foi contra ele e matou-o. É muito triste ver partir os nossos filhos na nossa frente...

Pesquisador: - Vosso marido, no mesmo dia que chegou, já foi trabalhar. E trabalhava em quê?

Sra. Brigite: - Ah! No mato, a cortar madeira, pinheiros, cortar toda espécie de madeira com uma tronçonosa ${ }^{55}$. Quando os filhos estavam mais grandinhos, ele

\footnotetext{
53 Sobre este termo nativo, ver nota de rodapé 19.

$54 \quad$ Carreira é a palavra que em Portugal utilizam para se referir aos ônibus.

55 Tronçonosa é uma corruptela da palavra francesa "tronçonneuse", que significa "serra-elétrica".
} São inúmeros os termos franceses e corruptelas que aparecem no meio do discurso dos emigrantes. Alguns pesquisadores afirmam se tratar de uma espécie de dialeto que tenha se constituído na diáspora portuguesa para a França, o "frantuguês" ou "françuguês". Ver a esse respeito Dias (1989: 43). Ainda 
pediu ao patrão - que era amigo dele, estavam lá muitos portugueses naquela coisa onde se trabalhava à jeira ${ }^{56}$ - se lhe arranjava um mato para trabalhar aos sábados e nas férias quando seus rapazes (filhos) não andavam na escola. O patrão lhe arranjava, lhe dava um mato para ele cortar e os filhos juntarem com as arelhas ${ }^{57}$, e ganhavam bem. Já naquela altura tinha uma paga muito boa. Quer dizer que trabalhavam muito, mas também ganhavam muito mais que em Portugal. Já se podia ter qualquer coisinha. Depois que começamos a ter dinheiro é que compramos cá: esta é a casa onde ele foi criado com a mãe, o pai e os irmãos... Foi tudo com o dinheiro de lá. Estamos aqui (em Portugal) sempre a comer o dinheiro da França.

Clóvis e Brigite viveram todos esses anos na cidade de Bordeaux, no sudoeste da França. É grande o número de portugueses que se instalou nessa região por diversos motivos, entre os quais por se tratar de região com oferta razoável de empregos e bastante mais próxima de Portugal do que Paris, por exemplo, por estar quase na fronteira com a Espanha. Conforme narra sua chegada à região de Bordeaux, Brigite diz o seguinte:

Sra. Brigite: - Para a vila em que fomos naquela altura só lá havia uma irmã minha e alguns outros poucos portugueses. Depois mais tarde havia muitos portugueses, mas até aquela altura eram poucos. As voisines ${ }^{58}$ viam que eu havia chegado

sobre o tema, ver www.frantugues.com, projeto do geógrafo Miguel Padeiro e de Eduardo Pereira para a compilação de termos desse dialeto em uma espécie de dicionário.

56

Jeira é um termo nativo, uma unidade de medida usada para designar trabalhos executados e pagos diariamente, por dia trabalhado. Era comumente utilizada como moeda de troca entre camponeses, que trocavam "favores" e tarefas do campo numa economia de dons, base dos vínculos sociais. As tarefas da agricultura eram comumente executadas conforme um esquema de troca de favores. Trocava-se o trabalho à jeira, ou seja, dias de trabalho equivalentes ou tarefas específicas (poda das videiras, colheita, aragem, etc.).

57 “Arelha" é uma ferramenta específica, um tipo de pequeno arado.

Palavra francesa que em português significa "vizinhas". 
na França com cinco meninos, e havia muitas francesas que iam até minha casa levar roupas muito boas para os meus filhos... ${ }^{59}$

O caso da senhora Aline (72 anos) e seu marido, Marcondes (75 anos), é bastante similar, e ocorreu também a partir do final dos anos 1960. Ele trabalhou na indústria metalúrgica por alguns anos (foi funcionário na linha de produção de uma fábrica de peças para carro), mas na maior parte do tempo que passou na França esteve empregado na construção civil, sobretudo em obras públicas (segundo Dona Aline, na construção e reparo de estradas e demais vias públicas). Antes disso, contudo, emigrou algumas vezes para temporadas de trabalho na Espanha, ora para contratas ${ }^{60}$ de trabalho na agricultura, ora para alguns meses de trabalho nas minas de carvão. Quem, no entanto, narrou toda a trajetória conjunta do casal foi a senhora Aline em virtude dos problemas de saúde de seu marido. Ela é uma senhora bastante comunicativa, matriarca de uma família extensa e mãe de quatro filhos, entre eles Inácio e Aloísio ${ }^{61}$. Conheci-a por meio de Inácio, que havia conhecido antes, durante pesquisa de campo no Café do Tavares. Ela resumiu da seguinte maneira sua empreitada migratória durante a entrevista:

Pesquisador: - Queria saber como e quando a senhora emigrou...

Senhora Aline: - Ah, filho! A vida na aldeia com meus pais foi trabalhar sempre. Bem novinha comecei... Olha, comecei a trabalhar aos 11 anos e pouco depois fui

59 A relação dos portugueses imigrantes na França com seus vizinhos franceses é algo variável. Brigite e Aline preferem descrever essa relação como harmoniosa e bastante agradável, segundo suas respectivas experiências pessoais. Há, no entanto, casos em que esse convívio é pautado pelo conflito ou pela indiferença, tal como será descrito adiante, em outro ponto do texto. Parte do grupo de agentes imigrante na França narrou alguma espécie de tensão vivida no âmbito da vizinhança no contexto de destino.

60 "Contratas" são uma espécie de regime temporário de trabalho de curta duração, oficializado por meio de um contrato de regulamentação desse ofício em sua duração e competências.

61 Ambos aparecem em outros momentos da pesquisa, sobretudo no último capítulo, quando discuto a festa e demais aspectos das relações sociais na aldeia. Os irmãos vivem atualmente juntos na França, nas proximidades de Paris, mas os conheci durante a etapa do trabalho de campo realizado em Vilas Boas. 
para o Porto ${ }^{62}$, trabalhar servindo ${ }^{63}$. O primeiro trabalho que fiz foi carregar com minhas colegas cântaros d'água na cabeça. Depois é que fui para o Porto servir...

Pesquisador: - Mas como é que foi isso? Já foi para o Porto com serviço arranjado, encaminhada?

Senhora Aline: - Sim, sim. Por pessoas da minha aldeia. Porque eu não sou daqui (de Vilas Boas). Sou de Valtorno, conheces? Já estou aqui há 49 anos. Casei-me no dia 2 de março de 1963 e desde então passei a viver em Vilas Boas porque meu marido é daqui. Vivemos aqui em diferentes partes. Primeiro foi ali na Lamela ${ }^{64}$. Estivemos ali quatro anos e nesse período meu marido emigrou para a Espanha, para as temporadas ${ }^{65}$. Passava lá três ou quatro meses, depois tornava cá vir. Esteve lá nas colheitas e nas minas de carvão. Passou algumas temporadas nas minas de carvão, uns quatro anos no total. Eu sempre aqui com os filhos... que remédio tinha? Tinha que aturá-los! Eram meus! (risos). Depois então meu marido emigrou com os primos dele para a França e lá esteve ainda uns quatro anos sem mim. Fui para lá com promessa de emprego na fábrica de peças em que ele estava, mas isso não foi possível. Meu marido conseguiu-me então trabalho na agricultura, mas era longe doze quilômetros de onde morávamos. Ao fim de quinze meses, meu marido é que foi trabalhar ao pé de mim ${ }^{66}$. Quis deixar seu patrão porque, enfim... trabalhava muitas horas e recebia pouco. Arranjou para trabalhar em obras, compor ${ }^{67}$ estradas. Esteve nesse emprego por quatorze ou quinze anos.

Importa notar da trajetória de Aline e seu marido o aspecto familiar como algo que produz contingências decisivas, como uma força que é parte relevante do processo complexo de produção dos percursos migrantes. Tal como apontado em outros momen-

\footnotetext{
62 Grande cidade e centro urbano na região costeira do norte de Portugal.

63 "Servir", neste caso, remete aos trabalhos ocasionais de faxina e limpeza prestados.

64 Lamela é um largo central de Vilas Boas, comumente citado como referencial geográfico para indicação de lugares e caminhos diversos.

65 Temporadas são os períodos em que são oferecidos contratos de serviços temporários denominados contratas.

66 A expressão "ao pé de” tem em Portugal o significado de "próximo de".

67 “Compor" é uma palavra que, em Portugal, assume principalmente o sentido de "arrumar” ou "consertar".
} 
tos, a família ressurge agora como um vetor componente da resultante emigratória ${ }^{68}$. Veja-se a esse respeito que a emigração de Dona Aline foi precedida e amparada pela de seu marido, mas foi condicionada, entre outras coisas, sempre pela disposição de sua sogra a cuidar de seus filhos. Entre idas e vindas, Dona Aline esteve na França por cerca de doze anos, enquanto seu marido lá permaneceu pouco mais de vinte anos.

Ademais, dessa trajetória extrai-se algo ainda, além da clara relevância da estruturação escorada em relações de parentesco: aqui mais uma vez lidamos com percursos vacilantes, idas e vindas para destinos diversos. As primeiras experiências emigratórias do senhor Marcondes e de sua esposa são de caráter temporário, mas criam para eles um universo de referências e experiências importante para uma empreitada mais extensa, de maior duração e que envolveu mudanças e ajustamentos mais complexos.

No final dos anos 1960 o volume da emigração geral de Portugal para a França era bastante grande e intenso e configurava uma clara tendência, refletida também em Vilas Boas. A metáfora comum do fluxo migratório pensado como uma corrente encontra fundamento na prática intensamente repetida por meio da qual um emigrante servia de "elo" a outro e assim sucessivamente, como um modo de retrofluxão da dinâmica emigratória. Do mesmo modo que as irmãs de dona Brigite e os primos do senhor Marcondes estimularam a migração dos agentes dessas trajetórias narradas, essa modalidade de incentivo à emigração adquire uma constância como prática cultural ${ }^{69}$.

A França desde a década de 1960 foi, portanto, o destino preferido da emigração portuguesa. E isso se percebe também no conjunto ou feixe de trajetórias dos migrantes de Vilas Boas. Esse fluxo em direção ao território francês manteve sua força e constân-

68 São inúmeros os trabalhos que abordam a relevância dos laços familiares na construção de percursos migratórios, tais como Machado 2009, 2009b e 2010; Brettell, 1991b e 2007, entre outros.

69 Aqui se coloca inicialmente a possibilidade de pensar a sedimentação da emigração como "padrão cultural” (ANTUNES, 1981:18). A migração, por assim dizer, suscita constantemente o passado e recobra-o no intercurso dos deslocamentos. Ou seja, a experiência emigratória acumulada serve de referencial para projetos que são atualmente estruturados por esse background. Frequentemente, relações interpessoais muito densas (de parentesco, por exemplo) servem como "ponte" para a emigração. E esse procedimento se reproduz ciclicamente, por meio de convites de uns aos outros, como elos de uma corrente. Por esse modo, o estatuto que ocupa a emigração a situa como “(...) uma longa linha de continuidade que une a população actual (...) ao seu passado histórico. Este elemento de continuidade gira à volta da escolha repetida da emigração como uma estratégia (...). A migração (...) [faz] parte de um sistema social lógico (...)" (BRETTELL, 1991:281). 
cia ao longo das décadas de 1970 e 1980, mas o quadro emigratório foi pontuado por algumas outras tendências. Entre elas, por exemplo, que o trabalho temporário por contratas constituía, em diversos casos, o princípio de um trajeto migrante. Nesse quadro, destaca-se para Vilas Boas a Espanha como um destino eminente, que recebeu grande contingente principalmente no começo dos anos 1970.

Tal como o senhor Marcondes, são muitos os que saíram de Vilas Boas para trabalhar na Espanha, na maioria das vezes em empregos temporários ligados aos períodos de plantio ou colheita de algum cultivo. No entanto, houve também um longo período em que a mineração do carvão na região noroeste da Espanha constituiu um destino bastante comum para homens jovens durante a década de 1970. Embora a Espanha estivesse em situação política semelhante à de Portugal, sob a ditadura do general Francisco Franco, tais oportunidades em território espanhol eram bastante buscadas, entre outros fatores, por conta da considerável renda adicional conquistada em um curto espaço de tempo. A remuneração para o trabalho na mineração de carvão era muito boa, segundo contam aqueles com quem pude interagir e que trabalharam por algum tempo como mineiros, sobretudo Damião, aquele que mais tempo exerceu essa função.

Desse modo, é com vistas a essa configuração local bastante específica que podemos destacar alguns polos-destino de relevância significativa para o recorte de pesquisa. Alguns lugares na França, sobretudo nas proximidades de grandes aglomerados urbanos, constituíram núcleos de convergência importantes para a observação etnográfica, tais como alguns bairros do subúrbio parisiense e a região em torno da cidade de Bordeaux. Ademais, algumas localidades na Espanha constituíram núcleos menores, mas igualmente importantes para a história local do fluxo migratório aqui delimitado, sobretudo na província de Castilla y Léon, próxima à fronteira com Portugal. Bembibre e seus entornos repletos de minas carvoeiras concentraram vilas inteiras de migrantes portugueses.

É com a consideração das trajetórias abordadas que - tomadas em seu conjunto e percebidas enquanto feixe de trajetórias com semelhanças de destaque - é possível conjecturar um quadro observável de relações transnacionalizadas e concentradas em nós. Os cruzamentos das trajetórias configuram nós biográficos que indicam momentos e destinos de relevância para a percepção dos modos como as relações sociais se distendem e deslocam com o transcurso dos agentes. Individual e coletivo estão enredados em implicações recíprocas, e destarte os elementos congruentes nos percursos individuais 
permitem conceber uma ideia ampla de "biografia coletiva". Podemos rastreá-la por meio dos "traços quase transparentes que, quando unidos a todos os outros traços dos grupos sociais, definem trajetórias comuns, feixes de percursos muito semelhantes, ou afinal, uma trajetória [coletiva]" (MONTAGNER, 2007:253, grifos do autor).

Mediante as contingências e situações complexas, ocasionadas pela aproximação e articulação de elementos de diversas ordens (local, global, micro, etc.) é que podemos de modo bastante primário restituir traços da formação local dos fluxos e tendências migratórias. Adotar a noção de biografia coletiva implica produzir um inventário das congruências significativas (ou seja, práticas e elementos tais como atividade profissional, origem social, etc.) entre as trajetórias, reunidas em feixes segundo o critério da semelhança de seus percursos.

Enquanto a migração portuguesa "tende a seguir as demandas de trabalho numa economia mundial em mudança" (FELDMAN-BIANCO, 1995: 93), importa-me captar essas transformações relacionadas, da economia global e da estruturação social local. Penso que as redes de relações transnacionais são, de certo modo e em algum nível, estáveis, estruturadas por uma prática continuada no tempo, mas que se reconfiguram contingencialmente, dando ensejo a formas emergentes de circulação e fixação, rearranjos necessários e de ajuste tenso e delicado.

Ademais, quando penso na transnacionalização de relações sociais e na formação de um novo espaço de ação menos delimitado territorialmente ou marcado por fronteiras, não é com o intuito de pensar novas fronteiras para o escopo da ação social dos agentes enfocados. A ideia consiste, na verdade, em adotar uma concepção da prática social percebida como contínua produtora de fronteiras simbólicas, territorializações ${ }^{70} \mathrm{e}$

\footnotetext{
70 O teórico Rogério Haesbaert se contrapõe às teorias demasiado amplas que afirmam a existência contemporânea de processos de desterritorialização quase como unidirecionais, sem nuances ou voltas que apontem direções diferentes. Ele chama a atenção para o fato de que aspectos desterritorializantes em processos sociais em curso não interditam reterritorializaões situacionais. Ao pensar na figura do migrante ("parcela integrante - ou que está buscando integração - numa (pós) modernidade marcada pela flexibilização - e precarização - das relações de trabalho" [2004: 238]), o autor busca colocar "em xeque a ideia preconcebida de que mobilidade é sinônimo de desterritorialização" (2004: 236). A partir de uma concepção mais dinâmica da noção de "território", Haesbert defende que "podemos conceber uma espécie de territorialização “no movimento" (Idem).
} 
localidades ${ }^{71}$. Ou seja, trata-se de produzir não a história dos grupos como realidades anteriores aos sujeitos, mas, sobremodo, a história das técnicas de produção de localidades, a saber, de mapear as reterritorializações, ou como nomeia Appadurai, de pensar uma "geografia pós-nacional" (1997: 46).

Desse modo, o trabalho segue adiante com feitio marcadamente etnográfico porque passa, a partir deste ponto, a se concentrar sobre o registro da observação dos quadros sociais configurados localmente nos contextos de destino. Importa, portanto, estabelecer uma descrição analítica densa sobre os modos de produção de localidades e territorialidades nos contextos de fixação dos migrantes, os modos de estruturação das relações, a constituição do espaço doméstico, do ambiente de trabalho e demais aspectos da vida cotidiana.

Além disso, o esforço se direciona simultaneamente para a observância de possíveis modos pelos quais as relações se sustentam distendidas pelo afastamento migratório. Ou seja, importa notar em que aspectos a vida estruturada no espaço de destino se relaciona de modo mais ou menos direto e íntimo à aldeia e, desse modo, colabora ainda de alguma forma com a dinâmica social aldeã, de modo a fazer-nos pensar na relativização de dicotomias baseadas na oposição entre origem e destino. O tipo de circulação enfocado, entre o espaço da vida social primária, da socialização familiar, e os lares construídos alhures, coloca em relação um grande número de espacialidades e temporalidades, que se superpõem e por vezes conjugam. Nesse sentido procuro notar as maneiras intermitentes pelas quais a emigração se torna "constitutiva do cotidiano português" (FELDMAN-BIANCO, 1995: 95).

A seguir concentro as reflexões em torno do material conquistado durante o trabalho de campo realizado na França e na Espanha em bairros e cidades em que se constituíram núcleos de vizinhança de portugueses migrantes. São relatos etnográficos que tratam do tempo de convivência com agentes emigrantes que pude acompanhar em seu cotidiano, bem como em suas viagens de retorno a Portugal. experiência humana" (GLICK-SCHILLER e ÇAGLAR, 2011:63, tradução minha), então a produção da localidade como "propriedade fenomenológica da vida social" (APPADURAI, 1996:182) é o ato pelo qual os atores engajam-se para organizar o espaço segundo "uma estrutura de sentimentos e sua expressão material de vivência da 'co-presença”' (APPADURAI, 1997: 34). 


\section{CAPÍTULO 2}

\section{“SENHORA DA ASSUNÇÃO, DAI-NOS BOA VIAGEM" 72; \\ O trabalho da memória e A PROduçÃo dA TRANSNACIONALIDADE NO CONTEXTO ESPANHOL}

O quadro aqui anteriormente exposto, a respeito da decadência do império colonial português, ajuda de certo modo a compreendermos as conexões lógicas entre o processo de formação da diáspora portuguesa e a constituição de campos sociais transnacionais ancorados em contextos locais - de onde partem os migrantes para percorrer trajetórias transnacionais. No entanto, as conjunturas e contextos (com as possibilidades e restrições que articularam) terminaram por eleger destinos preferidos e preteridos. Os países africanos (Angola e Moçambique), por sua parte, deixaram de ser destino comum para a leva emigrante portuguesa, já que as independências de cada um criaram contex-

\footnotetext{
72 A expressão destacada entre aspas foi extraída de uma bandeirola bastante popular entre emigrantes, vendida no Santuário de Nossa Senhora da Assunção (em torno do qual se concentram as festividades aldeãs tão ansiadas pelos emigrantes). Essas bandeirolas são usadas geralmente nos retrovisores dos veículos e são um exemplo destacável entre os muitos artigos similares vendidos como forma de gerar fundos para a manutenção do santuário. No entanto, vale pensar que a imagética, bem como o discurso produzido para esse tipo de artefato são, em grande medida, voltados para o contingente migrante. A frase mencionada é um claro exemplo das expectativas e conformações que se constituem acerca do retorno periódico dos emigrantes.
} 
tos (sobretudo políticos) desfavoráveis para se construir um percurso. Países da Europa Ocidental, por sua vez, passaram a ser o destino da massa humana que não interrompeu seu fluxo de saída de Portugal; pelo contrário, nos anos que sucederam o fim do regime salazarista e as independências africanas, a emigração alcançou índices altíssimos. Fato é que os países europeus vizinhos a Portugal se tornaram o destino de preferência da torrente migratória portuguesa, especialmente a França.

Em termos da complexa rede constituída com base nas relações sustentadas transnacionalmente, pontos de fixação de destaque se formaram, espécies de nós de cruzamento de relações relevantes para o escopo de um campo social delimitável. Emigrantes portugueses se deslocaram em números impressionantes para diversos destinos no continente europeu (Luxemburg, Alemanha e, mais recentemente, Suíça). Contudo, em vista das condições que abrangeram Vilas Boas, regiões específicas da Espanha e da França aglutinaram os nós do fluxo ali conformado, produzindo contextos de destino destacáveis como pontos de convergência. Com essa perspectiva é que decidi empreender parte do trabalho de campo nesses contextos construídos pelos agentes migrantes nos países de destino, com o intuito de observar e compreender os modos de construção do espaço e das práticas (e de um espaço para práticas) no cotidiano de trabalho e no período de lazer no contexto incerto da sociedade de destino.

Assim sendo, desenvolvo adiante descrições etnográficas da pesquisa empreendida na cidade de Bembibre, na Espanha com emigrantes provenientes de Vilas Boas. A pesquisa etnográfica multi-localizada começa daí a ser empreendida e passa a, desde então, seguir os agentes em suas demandas por mobilidade no âmbito dos fluxos do campo social transnacional. Foram momentos de pesquisa em que tive oportunidade de observar parte do cotidiano dos migrantes nos espaços de vivência e, ademais, realizar com eles a viagem de retorno a Portugal no mês de agosto, também descrita em seus aspectos relevantes notados. Parte dos imigrantes ainda hoje mora na Espanha, na mesma pacata cidadela marcada pelo passado atrelado à mineração, aposentados precocemente devido a diversos e sérios problemas de saúde, principalmente respiratórios. 


\section{- 2.1 "FOLLOW THE PEOPLE" 73 I: PELA ESPANHA}

O trabalho de campo na Espanha se centrou exclusivamente na cidade de Bembibre, na província de Castilla y León, noroeste da Espanha. Bembibre é bastante próxima da fronteira com o norte de Portugal e concentrou no passado, sobretudo na década de 1970, um grande número de empresas extratoras de carvão e minas de extração do mineral. Tal como assinalado anteriormente, o trabalho nas minas de carvão do noroeste espanhol foi ora ponto de passagem, ora ponto final de diversas trajetórias de emigrantes advindos de Vilas Boas. Fato é que Bembibre e seus arredores integram parte de um conjunto significativo de percursos migrantes ${ }^{74}$.

Neste ponto do trabalho tangencio mais uma vez aspectos autobiográficos importantes. Não é escuso considerar que o percurso emigratório percorrido pelo meu pai passou também por Bembibre, onde trabalhou por dois anos e meio na extração do carvão mineral. Ainda hoje vivem em Bembibre alguns migrantes provenientes de Vilas Boas. São os poucos que conseguiram ali se fixar desde meados da década de 1960 e hoje gozam as aposentadorias e benefícios pagos pela seguridade social espanhola, referentes ao trabalho que exerceram durante algumas décadas no fundo das minas de carvão. Dentre esses poucos está Damião.

Meu pai e Damião emigraram juntos e têm quase a mesma idade. Foram amigos na adolescência, quando mais conviveram, mas desde que meu pai deixou a Espanha e a mineração, nunca mais se viram ou falaram. Como trabalharam em minas diferentes, têm poucas recordações conjuntas do trabalho no princípio da década de 1970. Damião tem cinquenta e seis anos e vive hoje fundamentalmente de sua aposentadoria em um apartamento com dois dormitórios em Bembibre. Coincidentemente, Damião é atual-

\footnotetext{
73 Referência a um importante tópico do texto metodológico de George Marcus "Ethnography in/of the World System. The Emergence of Multi-Sited Ethnography” (1995: 90).

74 A respeito da atratividade de Bembibre como destino migratório, ver reportagem intitulada "El Crisol de Bembibre". A reportagem procura retratar Bembibre como uma espécie de "cadinho", de lugar que condensa não apenas um grande número de trabalhadores migrantes, mas uma imensa gama de países de origem e, portanto, "culturas". As histórias de vida enfocadas no texto também se relacionam de algum modo ao trabalho na mineração. A reportagem destaca ainda a língua portuguesa como a segunda mais falada na região, logo após o espanhol, devido à presença dos contingentes português e caboverdeano. Disponível em: http://www.diariodeleon.es/noticias/revista/el-crisol-de-bembibre 612292.html (acessado pela última vez em 18/09/2013).
} 
mente companheiro de Josefa, irmã do meu pai que viveu por muito tempo no Brasil (por isso ela era, até o início dessa pesquisa, a única tia que eu conhecia dentre os quatro irmãos que tem meu pai).

Meu pai é o filho mais velho de meus avós. Josefa é sua irmã, a segunda da sequência de cinco filhos que chegaram à maturidade. Suas memórias sobre esse período são relevantes para dimensionarmos aspectos da dinâmica familiar e das tensões envolvidas no afastamento que a emigração implica. Cabe recuperar aqui que, para Josefa, esse momento de partida do irmão mais velho foi também prenhe de tensões, segredos e afetos que de certo modo demarcaram a memória como um ponto referencial. Em uma entrevista que realizei com ela durante a pesquisa de iniciação científica que antecedeu o projeto desta pesquisa, ela reconstituiu da seguinte maneira a partida de seu irmão para a Espanha:

Ele [o irmão mais velho] e mais outros já tinham planejado tudo, mas nosso pai não sabia. Só eu e minha mãe sabíamos. Eu tentava disfarçar, mas chorava muito. Quando meu pai perguntava o motivo, eu mentia e dizia que sentia dor na barriga. Quando o pai descobriu pela boca de outros, ficou furioso, mas àquela altura meu irmão já estava na Espanha. Apanhamos por isso, eu e minha mãe. Já meu irmão ficou por lá uns anos, acho que três, e não se comunicou mais; acredito que pelo medo que tinha de falar com nosso pai. Tinha ele uns dezesseis anos naquela época. Então, quando era uma altura das festas que temos na aldeia, época em que muitos dos emigrados regressavam, juntavam-se os pais de emigrantes e diziam ao meu pai: “-Oh, Galego! O meu filho veio. E o teu, não vem?”, a que meu pai respondia: "-Este não ganha dinheiro para nada, nem para vir para a aldeia. Já nem sei qual vida que é a dele”.

Essa descrição é emblemática porque condensa elementos que falam da migração como processo que faz parte de uma lógica localmente configurada e que atravessa as relações sociais, sobretudo aquelas que constituem o grupo familiar. Ouvir essas histórias familiares, prenhes de memórias e conflitos íntimos, ajudou a estabelecer uma aproximação inicial da constituição de uma trajetória migrante, entranhada por negociações tensas e relações de poder próprias do núcleo familiar. 
Damião, por sua vez, se divorciou há algum tempo de sua primeira esposa e vive há não mais que cinco anos com Josefa ${ }^{75}$. Assim que ambos souberam dos meus interesses de pesquisa pela migração e trajetórias migrantes, se dispuseram a ajudar. Como Josefa só passou a viver em Bembibre depois que se uniu a Damião, ele é que passou a ser o principal colaborador e intermediário do trabalho de campo desempenhado na Espanha.

Na verdade, na data da emigração conjunta supracitada, Damião já conhecia a Espanha quando por volta de seus dezesseis anos decidiu deixar Vilas Boas. Ele vive em Bembibre desde essa data e conhece bem a cidade, a história de suas últimas décadas, o apogeu e a decadência da atividade mineira, e constantemente recorreu a recordações em nossos diálogos com uma nostalgia acentuada.

Como colaborador-chave dessa etapa da pesquisa, Damião apresentou-me a cidade por meio de descrições de memórias e caminhadas. Ao longo dessa interação, ele sempre inseria elementos biográficos relacionados aos percursos e espaços que observávamos, a partir dos quais pude remontar significativamente sua trajetória migrante.

Segundo narrou, suas experiências migratórias começaram bastante precocemente, em virtude de fatores de ordem familiar: Damião ficou órfão de mãe ainda durante a infância e seu pai passou períodos em empreitadas emigratórias, temporadas para compor a renda familiar. Ele acompanhou seu pai algumas vezes nesses caminhos e deslocamentos, mas começou sua trajetória particular no início da adolescência. Porém, como a maioria das trajetórias migrantes, passou por inúmeros lugares, inclusive a França. Conforme antes assinalado, a migração comumente porta essa característica um tanto nômade, sobretudo em seu momento inicial.

No entanto, a condição de "iniciado" que a migração precoce propiciou a $\mathrm{Da}$ mião concedia-lhe um lugar especial na ritualística do processo emigratório dos que ainda pretendiam migrar. Damião, em suas falas, se coloca no lugar de um pioneiro, alguém que antes dos demais chegou a lugares almejados. A emigração não era, absolutamente, um fenômeno novo para Vilas Boas no começo da década de 1970. Muitos já haviam partido e retornado, bem-sucedidos ou malfadados, e eram muitos os exemplos

\footnotetext{
75 Vale destacar que a ex-esposa de Damião também é portuguesa. A partir dessa informação comecei a notar algum padrão de nupcialidade entre migrantes que discuto brevemente no capítulo seguinte.
} 
notáveis ${ }^{76}$ que ajudaram a conformar uma dinâmica de mobilidades e possibilidades. Damião, por sua vez, catalisou a iniciativa de diversos outros agentes já que realizava constantemente o trânsito entre a aldeia e destinos diversos.

Numa dessas vindas de Damião a Vilas Boas, um grupo de rapazes (meu pai entre eles) decidiu acompanhá-lo de volta à Espanha. Contaram com sua intermediação, que por sua parte, além de ter contatado um passador, foi quem primeiro lhes apresentou emprego na mineração. Emigraram em um período em que era bastante comum sair clandestinamente do país, com o auxílio de passadores que atuavam como mediadores para os grupos que queriam atravessar a fronteira sem passar pelo crivo da burocracia do Estado. Cruzaram, portanto, ilegalmente a fronteira, correndo os riscos inerentes. A rota marginal afastava-se das autoestradas e ferrovias, por entre silvas e a vegetação rasteira, e terminava do lado espanhol da fronteira, após cruzarem o riacho fronteiriço em algum trecho pouco vigiado e raso. O jovem grupo trabalhou junto ainda por um tempo até que por diversos fatores as trajetórias divergiram.

Daí em diante os regressos de Damião à aldeia se tornaram gradativamente mais espaçados até cessarem completamente, sobretudo devido a seus conflitos familiares. Foi desse modo que Damião construiu uma trajetória de afastamento migratório que só encontrou possibilidades de reaproximação bastante tardias, condicionadas por uma lenta reconstrução de novas relações e principalmente antigas relações desvanecidas.

Damião encontrou a procurada fixação na cidade de Bembibre, ligando-se à atividade mineradora, na extração do carvão. Trabalhou enterrado ${ }^{77}$ por vinte e quatro anos para a Minex ${ }^{78}$, maior extratora da região, e passou ainda alguns anos antes de se

76 Para pensar como trajetórias migrantes podem ensejar novas trajetórias é importante observar a discussão empreendida anteriormente, em torno das trajetórias narradas pelos aldeões mais velhos, tidos como pioneiros locais do ímpeto migratório. Esse tema será discutido novamente adiante, a partir dos contextos etnográficos.

77 Este pode ser tomado como um termo nativo, usado por trabalhadores e ex-trabalhadores da mineração de carvão para se referirem à sua atividade de trabalho, realizada em minas subterrâneas, há vários metros de profundidade e, em diversas ocasiões em veios bastante estreitos, onde só podiam se colocar deitados.

78 Pronuncia-se "Mines", conforme reproduziram todos os que por algum motivo citaram a referida empresa mineradora. A Minex era a principal extratora da região, a maior delas segundo afirmaram diversos ex-mineradores, e por isso foi constantemente citada nas falas dos agentes que integram essa pesquisa. 
aposentar, recebendo benefícios sociais afastado de suas funções, devido a complicações respiratórias decorrentes do trabalho exercido.

O trabalho era extremamente severo e arriscado e também por isso nem todos insistiam na empreitada. Segundo descreveu Damião, muitos desistiam e voltavam para Portugal, para a aldeia; outros trocavam de cidade e de atividade. Os que persistiam no trabalho de mineração obtinham, além de cicatrizes escurecidas pela sedimentação do pó de carvão sobre as feridas e algum nível de silicose ${ }^{79}$, uma aposentadoria precoce. Em suas palavras,

o trabalho nas minas é muito arriscado. Perdi três ou quatro companheiros ainda muito jovens a trabalhar na mineração. Todos os dias sabes que entras, mas não sabes se vais sair vivo. Eu mesmo trabalhei enterrado por vinte e quatro anos, como martillador ${ }^{80}$. Depois disso fui afastado. Recebia mas não trabalhava, isso desde os meus quarenta e poucos anos.

79 Silicose é uma doença respiratória irreversível e incurável, resultado da longa exposição ao ambiente subterrâneo das minas de carvão e inevitável inalação da sílica cristalina presente no pó de carvão. A silicose é fatal e progride com a exposição continuada ao pó de sílica presente no carvão mineral. Como os efeitos da silicose tendem a piorar gradualmente o estado de saúde do doente, o progresso da doença é avaliado por níveis segundo sua gravidade. Existe, por isso, uma relação diretamente proporcional entre o estágio da doença e o valor da pensão paga pelo Estado espanhol aos afetados pela doença, e inversamente proporcional entre estágio da doença e expectativa de vida. Segundo os relatos, eram comuns mortes de indivíduos de meia-idade, entre quarenta e sessenta anos, por complicações respiratórias decorrentes de décadas de trabalho. Damião foi diagnosticado com silicose de nível 1 e recebe pensão adicional por isso. Em virtude dos danos irreversíveis de saúde contraídos no trabalho de mineração, vi Damião ter crises de tosse terríveis, intermináveis, por vezes acompanhadas de uma falta de ar angustiante e às quais custei a me acostumar.

80 Martillador em espanhol - ou "martelador", equivalente aportuguesado - era o trabalhador encarregado por quebrar com uma pequena britadeira as pedras de carvão das paredes nos pequenos veios abertos para extração na mina. Tal como nessa ocasião, Damião continuamente não se lembrava de termos em português durante nossos diálogos e misturava em sua fala o espanhol. 
Além dos amigos mortos em trabalho que Damião enumerou em uma de nossas conversas, vale também recuperar aqui suas lembranças sobre as experiências de trabalho em que arriscou sua vida e viu seus companheiros arriscarem as suas. Essas lembranças ocasionais, que emergem em meio ao diálogo, são uma maneira de explorar indicialmente questões relativas à experiência migratória. Ele descreve e interpreta da seguinte maneira o trabalho nas minas:

Vi alguns amigos serem soterrados. Outros tantos serem tirados mortos de dentro das minas. Aquilo mexia comigo. Não consegui dormir e às vezes nem comer. Pensava que aquilo não fosse trabalho de gente. Mas era preciso persistir. Eu não podia voltar e escavar era o que me restava.

Tal como Damião, Jaime, seu amigo, tem uma história para cada uma de suas cicatrizes e manchas de carvão pelo corpo. As consequências do trabalho na mineração, portanto, acompanham os mineiros por toda a vida, seja por meio de suas lembranças, seja pelas cicatrizes ou ainda pelas doenças respiratórias que perduram.

Damião expressa forte nostalgia pelo período em que trabalhou como mineiro e, em certas ocasiões, evidencia alguns traços de uma identidade profissional que ainda o liga a outros ex-mineiros aposentados com os quais trabalhou. Essa experiência de trabalho intensa e durável gera laços sociais igualmente duradouros. Inclusive porque grande parte dos trabalhadores mineiros era composta de portugueses. Assim como os supracitados adolescentes companheiros que emigraram de Vilas Boas, portugueses de diversas regiões do país se dirigiam ao noroeste espanhol para trabalhar na mineração e ali se instalavam inicialmente em pequenas pensões nos vilarejos próximos às minas. Os pensionatos, segundo descrições de ex-mineiros como Jaime e Damião, tinham grandes quartos coletivos para quatro ou mais hóspedes e ofereciam refeições e lavagem das roupas de seus usuários. Desse modo, os recém-chegados encontravam nos vizinhos de cama do quarto de pensão alguém com quem tinham diversos pontos de identificação, a começar pelo idioma pelo qual se comunicavam. Em um contexto estranho aos recémchegados, a língua estrangeira era um dos maiores entraves a serem superados. Nesse sentido, cabe lembrar Albano Cordeiro quando diz que 
“para todo português, um 'outro português' é potencialmente um 'comunicante', e um comunicante precioso. A sua história pessoal, os relatos da sua experiência, dos dissabores e sucessos que ele pode contar acerca de outros portugueses, são uma fonte vital de informações para ele próprio se poder orientar num meio que lhe surge opaco" (1993: 364).

Jaime disse algumas vezes ter sido auxiliado por Damião quando chegou. Sem saber por onde começar, a cidade se apresentava como um espaço sem referências habituais, inóspito e repleto de lugares e coisas desprovidos de significados. O estranhamento com relação à cidade era atenuado pela familiaridade possível com os demais imigrantes, com quem a proximidade que se estabelecia apresentava uma porta de acesso para uma forma demarcada de apropriação inicial da cidade.

Damião, por sua vez, insistia em suas memórias sobre a sociabilidade do trabalho mineiro. E reconhecia a dinâmica que alimentava a emigração, elaborando uma verdadeira teoria nativa para explicá-la. Ao recordar os rapazes da aldeia entusiasmados pelas possibilidades que ele lhes apresentava sobre a vida e o trabalho na Espanha, Damião analisa e avalia o seguinte:

Naquele tempo chegamos a ser uns setenta da aldeia nas minas de carvão na Espanha. Um puxava o outro e os jovens da aldeia acabaram quase todos para lá enfiados. Uns serviam de intermediários aos outros. Cada vez que tornavam à aldeia levavam consigo mais dois ou três e ajeitavam-lhes pensão e até mesmo trabalho, se calhasse.

Destino comum a muitos rapazes de Vilas Boas em princípios da década de 1970, a mineração do carvão era especialmente atraente por inúmeros fatores, segundo justificaram Damião e Jaime, ex-mineiros: Bembibre fica próxima à fronteira e o regresso ocasional tornava-se plausível, a remuneração era sensivelmente maior que em outras funções que empregavam mão-de-obra não-qualificada e, por fim, era uma via 
por meio da qual o emigrante conquistava certa estabilidade no emprego por meio da regulamentação de sua documentação e a conquista de direitos trabalhistas, já que, por conta das condições de trabalho, tinham quase invariavelmente a saúde comprometida.

No entanto, a Espanha não constituiu, em verdade, uma notória tendência emigratória em Portugal, mas para os habitantes de Vilas Boas representou um fluxo localizado bastante intenso e, dado o recorte de pesquisa, de extrema importância. As pensões que acolheram os migrantes - sobretudo nos primeiros anos de trabalho de cada um constituíram núcleos de habitação em torno das minas e eram um espaço vivo porque habitado e praticado. Solidariedades foram construídas a partir das relações de convívio e proximidade encetadas no pequeno espaço que abrangia o local de trabalho e de moradia.

Hoje os vilarejos próximos às minas estão praticamente desabitados. As pensões, fechadas e abandonadas, garantem o aspecto decadente das antigas áreas de trabalho e suas proximidades. A cidadela mudou sua geografia marcada anteriormente pela atividade carvoeira. Os entornos abandonados das minas estão em geral tomados pela vegetação e o terreno das minas cercado por telas de arame.

Com o declínio e a mecanização da atividade mineradora do carvão, Bembibre reorientou seu crescimento, a despeito de toda a estrutura criada em torno das minas, e passou a concentrar a população próxima a seu centro. A atividade econômica em grande parte ainda gira ao redor da mineração, porém agora a extração de carvão reduziu drasticamente sua demanda por mão-de-obra e, nesse ínterim, ganharam destaque as empresas extratoras de pedras de basalto.

A cidade é pequena, tem atualmente algo em torno de dez mil habitantes e não mais que sessenta e quatro quilômetros quadrados ao todo. Fica incrustada em um vale, cercada de morros em uma região de muitas elevações rochosas. Também por isso os invernos são bastante frios e intensos.

Esses aspectos genéricos e previamente conhecidos de Bembibre se confirmaram para mim na medida em que me aproximava da cidade. Conforme combinado, nos encontramos pela primeira vez no aeroporto do Porto, no noroeste de Portugal. Damião preferiu que isso se desse no Porto, mais próximo de Bembibre que o aeroporto espanhol de Madri. Desse modo, o caminho que percorremos de Portugal à Espanha foi em grande medida o mesmo percorrido por ele muitos anos antes em suas primeiras experiências migratórias. 
O caminho até a Espanha foi revelador em diversos aspectos. O percurso feito de carro repetiu de modo significativo os trajetos percorridos décadas atrás, quando muitos peregrinavam até a fronteira para cruzá-la furtivamente, longe do alcance do olhar do regime ditatorial. Percorremos um caminho de memórias, portanto. Foram horas de conversa paulatinamente cada vez mais franca e confidente, bastante calcada em memórias da emigração e do trabalho. Damião apresentou-se bastante disposto a contribuir com a pesquisa, expondo de modo extenso e detalhado aspectos do seu passado. E é importante notar nesse percurso as modalidades de interação que foram construídas, bem como as representações que foram interpostas, a fim de criar um espaço de diálogo.

O tom memorialista de Damião primou em recuperar aspectos biográficos de relevância de sua trajetória. Nesse momento inicial suas falas enfatizaram lembranças da infância na aldeia, anteriores à emigração, carregadas de experiências negativas associadas aos seus problemas familiares e às situações de escassez, às agruras da ditadura e os riscos da emigração ilegal e do trabalho na mineração. Em suas palavras:

Olha, aqui trabalhávamos muito. Mas tudo o que trabalhávamos era para fugir da fome. Havia muita miséria, isto sim. Muitos não dizem por vergonha, mas a verdade é que havia muita fome na aldeia. $O$ trabalho era pesado e não havia dinheiro, pagavam muito pouco. Havia aqui quatro ou cinco ricos. No mais, éramos todos pobres. Trabalhávamos a dois ou três euros por semana. ${ }^{81}$

Além do mais, o trajeto foi em certa medida reconstruído narrativamente por Damião por meio de rememorações, e para isso recorria continuamente às imagens do caminho. Damião apontava seguidamente marcos desse percurso que de algum modo revelavam algo a respeito da dinâmica migratória. No antigo portal alfandegário que demarca a divisa entre Portugal e Espanha, ele fez questão de parar por alguns minutos,

\footnotetext{
81 Nessa fala Damião realizou uma rápida operação mental que repetiu frequentemente em outras ocasiões, por meio da qual converteu o valor recebido nos termos da antiga moeda portuguesa para o Euro, atual moeda da Comunidade Europeia, da qual Portugal faz parte. Esse raciocínio de conversão matemática se tornou comum entre aqueles que passaram pela transição das moedas nacionais para a moeda comum da zona europeia de livre comércio.
} 
descer do carro e apontar de onde era feita a vigilância e como se comportavam as sentinelas do policiamento de fronteira. Apontou ainda os pontos de travessia do riacho, mais rasos durante a vazante de verão, e lembrou a viagem que fez aos dezesseis anos.

Atravessamos rapidamente as sinuosas curvas no interior de Portugal e cruzamos a cidade de Chaves ${ }^{82}$, a última antes de cruzarmos a fronteira. Entramos na Espanha pelo acesso a norte de Portugal e passamos rapidamente pela Galícia. O restante do caminho até Bembibre é cercado por grandes propriedades de produção agrícola (principalmente trigo) e, por vezes, era possível avistar a linha férrea também utilizada em tentativas de ingressar no território espanhol.

Damião elabora juntamente com suas lembranças uma ampla argumentação que lhe servia como forma de elaborar logicamente e encadear sequencialmente as histórias pessoais por ele narradas e amarradas em um todo abrangente e coerente ${ }^{83}$. Por esse modo suas memórias estão também entremeadas por juízos e interpretações tanto de sua própria trajetória quanto da migração como fenômeno amplo. Alguns valores surgem nesse momento como fundamentos de uma "moral" emigrante: a empreitada migrante compreendida como ímpeto de afastamento exige do agente que se move uma aspiração pela liberdade enquanto objetivo abstrato.

Conquistar independência financeira e se desvincular do núcleo familiar representavam, por um lado, a máxima realização dos jovens solteiros que emigravam (que, segundo indicam Caroline Brettell (1991: 111-113) e Robert Rowland (1997: 145), são

82 Chaves é uma cidade referencial do percurso não só porque é a última antes de se atingir a Espanha, mas porque é de porte médio, com mais de dezesseis mil habitantes, e trecho de passagem importante, local onde comumente se realizava uma pausa na viagem quando se procurava emigrar ilegalmente, segundo relata Damião.

83 A enunciação espontânea de aspectos biográficos se expressa de modo tal que o sujeito do enunciado procura, em geral, produzir um discurso totalizante e linear sobre sua própria trajetória. Enquanto realiza esses enunciados, produz sua história como uma realidade lógica e concatenada. Ao mesmo tempo em que apresenta ao interlocutor pesquisador a lógica que constituiu, também organiza essa lógica para si mesmo, como forma de acionar o passado como totalidade coerente. Como afirma Brettell, "Através das narrativas as pessoas tecem suas experiências em uma totalidade coerente (...). Indubitavelmente as narrativas também ajudam o etnógrafo a entender como as pessoas atribuem sentido ao seu mundo" (BRETTELL, 2003: 25, tradução minha). 
parte expressiva do contingente migrante ${ }^{84}$ ). $\mathrm{O}$ ambiente patriarcal dos grupos familiares contribuía com fatores de outras ordens para o ímpeto migratório. As histórias de emigrantes são atravessadas continuamente por tensões inerentes ao grupo familiar: a autoridade patriarcal é constantemente acionada como justificativa para o afastamento ${ }^{85}$.

Os relatos que ouvi de emigrantes dessa geração (nascida entre fins da década de 1950 e princípio da década seguinte) contam que muitos dos que emigraram jovens, quando ainda trabalhavam na aldeia tinham que entregar seu salário integral (ou ao menos a maior parte dele) nas mãos do pai. Toda a economia doméstica era gerida exclusivamente pelo pai, que acumulava os rendimentos do trabalho de todos os membros da família e escolhia a destinação dos gastos. A fala irônica de Damião revela algo a esse respeito quando diz: "pedi ao meu pai que me comprasse umas calças. Ele nunca as comprou, então fui comprá-las eu mesmo na Espanha".

Por outro lado, a busca pela realização dos prezados valores da liberdade e da independência é na maioria das vezes acompanhada da projeção permanente de um retorno. Portanto, não se trata de uma desvinculação irrestrita com relação ao núcleo familiar primário, mas um afastamento tenso que termina por se constituir em uma espécie de "rito de passagem". Para o emigrante, ainda que realize seu deslocamento em grupo, a migração apresenta-se como um período de mudança, de transição e, por vezes, de liminaridade ${ }^{86}$. O retorno é, nesse quadro, a etapa final de um processo nem sempre

84 Segundo Brettell "é seguro afirmar, e não sou de modo algum a primeira a fazê-lo, que não só a emigração de Portugal continental se concentrava na parte norte do país, como era predominantemente uma emigração de homens, quer solteiros, quer casados" (1991: 111).

85 Nobre e Portela relatam o seguinte acerca de sua pesquisa na aldeia trasmontana de Pinela: "E esta [a emigração] concretiza-se porque há também, por todo o país, a família patriarcal, não raro severa, um clima social fechado e senhorial e uma atmosfera política opressiva que alimentava desigualdades gritantes entre os 'ricos, remediados e pobres'. Em regra, as necessidades básicas e, por conseguinte, as mais modestas aspirações não podiam ser satisfeitas no plano local, nem mesmo regional ou nacional" (2001: 1112).

86 Nesse ponto da análise adoto a noção de "rito de passagem" proposta por Arnold Van Gennep como uma metáfora para enfocar o processo migratório nas trajetórias individuais. Segundo Van Gennep, os ritos de passagem são aqueles que têm por função "fazer passar um indivíduo de uma situação determinada a outra situação igualmente determinada" (2011: 24). Os ritos ditos de passagem incluem uma fase de marginalização do indivíduo, ou de "liminaridade", com a qual comparo a situação do emigrante quando passa um período de verdadeiro exílio até que possa voltar para a aldeia pela primeira vez e ser reinserido no grupo segundo as atualizações que sua nova condição lhe proporcione. 
concluído ou bem fadado de afastamento e reaproximação. Damião expressa com austeridade seu próprio exemplo diante da dureza da migração precoce e do trabalho mineiro:

Havia também aqueles que não conseguiam desgarrar das saias da mãe e voltavam logo a estar ao pé dos pais. Isso porque eram fracos, não tinham o espírito de liberdade para poderem se arranjar. Eu já aos quatorze anos emigrei e tive de me virar. Alguns anos depois da morte da minha mãe, meu pai passou a morar com outra mulher, e eu não podia estar com aquela situação, não podia me adaptar. Fui então estar sozinho, longe, mas sem dinheiro nem trabalho passei ainda maus bocados, tendo de dormir como cão em obras e coisas assim.

A fala de Damião nos remete aqui a uma apreciação da capacidade dos agentes de se afastarem e desvincularem em alguma medida do núcleo familiar dos seus pais. Contudo, o que está em questão aqui não é tão somente a efetividade na produção de novas centralidades ${ }^{87}$ (ou seja, de convergir e arranjar um conjunto significativo de relações), mas de escapar do espectro do poder patriarcal, de uma esfera de autoridade hierárquica, que se rompe no afastamento migratório. Nisso se caracteriza o aspecto disruptivo das trajetórias migrantes, mas não demarca um rompimento definitivo e absoluto ${ }^{88}$.

Desse modo, o retorno almejado pode demorar mais ou menos para se realizar considerando-se que é condicionado por inúmeros fatores, entre os quais podemos enu-

87 A centralidade aqui se refere à capacidade dos núcleos familiares aglutinarem um conjunto significativo de relações, de fazê-las convergirem para si e gravitarem ao seu redor. Isso se relaciona ao desejo de articular relações e construir a autonomia (social e financeira) com relação ao grupo familiar dos pais, sem no entanto se desligar completamente da centralidade que se constitui ao redor do núcleo paterno. Trata-se de um jogo complexo de distanciamentos e aproximações, de circulação por "casas", nós que simbolizam os conjuntos de relações a elas associados. Nas palavra de Igor de Renó Machado, "é uma questão de autonomia em relação a outrem, às relações de outrem" (2010: 14).

88 Esse afastamento premido por tensões do grupo familiar é marcado por um jogo de afastamentos e reaproximações. Vale destacar, tal como Igor de Renó Machado, que "um mesmo conjunto de pessoas que se ligam por parentesco convive com várias casas com níveis distintos de capacidade de aglomerar relações e pessoas" (2010: 13). 
merar o sucesso da empreitada apreciado pela ascensão financeira do migrante, mas sobretudo, a vitalidade dos laços sociais, principalmente de parentesco ancorados na aldeia. Retornar à aldeia tem muitos sentidos que serão explorados adiante, mas dentre eles está o interesse do migrante em continuar integrando o conjunto de relações que convergem para o contexto aldeão. A esse respeito discutirei adiante o conjunto de fatores que primeiro afastaram e posteriormente, recentemente, reaproximaram Damião do contexto aldeão.

\section{- 2.2 "CAMINHADAS PELA CIDADE" ${ }^{89}$ : HISTÓRIA LOCAL E PRÁTICA ESPACIAL}

Durante os dias que permaneci na Espanha circulei bastante por Bembibre, muitas vezes acompanhado por Damião, que tem o hábito rotineiro de circular pelo local, caminhar diariamente e várias vezes ao dia. Ele costuma circular pelo comércio local onde cumprimenta velhos conhecidos, pelas praças onde repousa e conversa com outros aposentados que têm no tranquilo espaço público de Bembibre um local de sociabilidade e lazer, onde interagem, jogam, conversam e passam longos períodos do dia durante o verão. Entre eles conta-se um grande número de portugueses que realizam constantemente o movimento pendular de idas e vindas entre Portugal e Espanha, sobretudo no período do verão.

As primeiras caminhadas que realizamos serviram principalmente para reconhecimento de um cenário totalmente novo para mim. Reparei inicialmente que cidade é fundamentalmente composta de pequenos edifícios residenciais, de quatro ou cinco andares. Havia na época um conjunto significativo de obras inacabadas e abandonadas, além de moradias vacantes e à venda, reflexo da crise atual econômica que afeta larga parcela da população. Além dos esqueletos de edifícios inutilizados, há uma porção central de prédios, ainda menores, com a fachada desgastada e um estilo arquitetônico antiquando, diferente dos prédios mais novos, em que está instalada a maior parte do comércio. São edificações mais antigas, muitas delas em ruas de pavimento onde não cir-

\footnotetext{
89 Referência direta ao sétimo capítulo do livro "A Invenção do Cotidiano. Artes de Fazer", de Michel de Certeau (2011 [1994]: 157-177).
} 
culam automóveis e estão mais próximas dos pontos referenciais turísticos do local, tais como a igreja de San Pedro Apóstol, numa espécie de centro histórico da cidade.

A paisagem montanhosa que cerca o local é onipresente, pois para qualquer direção que se olhe é possível avistá-la. Entre as montanhas é possível ver ainda um conjunto de cataventos. A substituição extensiva do carvão mineral por fontes de energia limpas e renováveis transformou as características da cidadela, hoje cercada por moinhos para captação de energia eólica. Quando, antes de chegarmos a Bembibre, passamos pelos tortuosos e montanhosos caminhos de morros e montes, Damião e Josefa haviam apontado os moinhos de vento, qualificando-os como uma das causas da inativação das minas carvoeiras ${ }^{90}$.

Não demorou muito para que essa percepção da cidade se sedimentasse com a observação. Imediatamente me vieram à memória as descrições elaboradas por Cornélia Eckert para descrever a comunidade de La Grand-Combe, na França. Assim como Bembibre, La Grand-Combe teve durante um longo período suas características espaciais conformadas pela atividade mineradora do carvão. $\mathrm{O}$ declínio abrupto da atividade gerou efeitos semelhantes para ambas. É válido para Bembibre o que Eckert afirma so-

90 A inativação das minas de carvão continua seu processo lento e gradativo. Em 2011, quando fiz pesquisa em Bembibre, Damião estava comovido com as mais recentes greves de mineiros que protestavam contra novas minas desativadas. Os trabalhadores mineiros organizados iriam realizar uma marcha de protesto até Madrid e Damião havia ido acompanhar os protestos antes da saída da marcha. Durante as manifestações, os mineiros costumam entoar um cântico em honra a Santa Bárbara (também chamada de Maruxina), santidade católica considerada patrona de diversos grupos de trabalhadores, entre os quais os mineiros. Transcrevo a seguir a canção, sucedida pela tradução de cada verso nos trechos entre colchetes:

En el pozo María Luisa, [No poço Maria Luísa,]

tranlaralará, tranlará, tranlará [tranlaralará, tranlará, tranlará]

murieron cuatro mineros. [morreram quatro mineiros.]

Mirai, mirai Maruxina, mirai. [Veja, veja Maruxina, veja.]

Mirai como vengo yo. [Veja como venho eu.]

Traigo la camisa roja [Trago a camisa vermelha]

de sangre de un compañero. [de sangue de um compañero.]

Traigo la cabeza rota, [Trago a cabeça quebrada]

que me la rompió un costero. [rompida pela encosta.] 
bre a cidadela francesa que "encolheu-se na função de vila-dormitório, de vila de aposentados" (2012: 66) ${ }^{91}$.

O trabalho etnográfico de Eckert centra-se nas relações de sociabilidade sustentadas pelos trabalhadores mineiros aposentados, e de certa forma são relações de aspecto bastante semelhante ao que pude observar no contexto espanhol. O forte sentimento de nostalgia que cerca o desvanecer da comunidade mineira (estímulo à relembrança dos tempos de intensa atividade nas minas) é permeado por um esforço continuado de reconstrução do conjunto de relações.

Desse modo, caminhar por Bembibre com Damião era não somente caminhar por suas relações sociais em terreno espanhol, mas (significativamente), por suas relações sociais entre portugueses na Espanha, antigos companheiros dos anos de trabalho. Nesse entremeio ele falou sobre suas impressões sobre Bembibre: de como sentia que o lugar estava envelhecido, repleto de aposentados antigos trabalhadores do carvão, beneficiários da seguridade social espanhola. São relações de vizinhança que persistem e se estendem pela circulação transnacional. Nesse momento do trabalho de campo conheci Jaime, amigo de Damião com quem trabalhou muitos anos.

Jaime é imigrante português, mineiro aposentado e que vem também de uma aldeia do nordeste de Portugal bastante próxima de Vilas Boas. Também por isso ocorre uma intensa troca de favores entre Damião e Jaime: ambos levam e trazem encomendas de Portugal para a Espanha, fazendo circular entre as aldeias e Bembibre bens de toda espécie. Fazem assim circular uma comunicação que remessas que amparam transnacionalmente relações sociais para além dos períodos festivos de intenso retorno ${ }^{92}$.

Jaime é uma figura interessante desse momento do trabalho de campo porque, desde sua apresentação, passou a nos acompanhar em diversas ocasiões e interagir com Damião de modo bastante instigante. Além dessa espécie de contínua troca de favores por meio de encomendas transportadas nos contínuos movimentos de circulação, sua convivência na Espanha trouxe elementos importantes para a reflexão etnográfica sobre

$91 \quad$ Eckert nota uma "estranha transformação de uma vila que passou a ter nos benefícios dos aposentados sua maior fonte de renda. O número expressivo de aposentados justifica-se pelo fato de constituírem eles uma "população protegida" (Idem: 70), ou seja, assegurada pelos benefícios pagos pelo governo, conforme também assinalei para Bembibre anteriormente.

92 Dinâmica semelhante se estabelece na França de modo mais intenso. Abordarei esse aspecto no capítulo seguinte. A esse respeito ver Levitt, 1998 e Brettell, 2007. 
a formação e a posição do contexto de Bembibre nos quadros do campo social transnacional. Esses elementos surgiram sobretudo durante nossas caminhadas conjuntas.

Caminhadas por Bembibre: a cidade mineira e suas imagens da mineração

As caminhadas por Bembibre se deram sobretudo na companhia de Damião. Delas é preciso destacar a forma específica pela qual Damião experimenta a cidade, intimamente relacionada com sua trajetória migrante e sua identidade de trabalho, ou seja, com sua condição.

Seus trajetos e referências suscitam os modos pelo qual ele e outros migrantes atuaram e atuam na produção do espaço em Bembibre. Essa produção singular se revela nos passos de cada caminhada, sugerindo algo que Michel de Certeau chamaria de "enunciação pedestre". Através de uma homologia entre o ato de caminhar pela cidade e o ato da fala, Certeau entende que caminhar é produzir um enunciado sobre o espaço na medida em que envolve "um processo de apropriação do sistema topográfico pelo pedestre" (2011 [1994]: 164).

Nossos percursos pela cidade eram pausados. Damião tem sua capacidade respiratória limitada, resultado da longa exposição que teve ao ambiente das minas. Ademais, as pausas eram um alento importante para interações com conhecidos que encontrava pelo caminho. As conversas eram, via de regra, em espanhol, mesmo quando se davam com outros portugueses imigrantes. Damião já não consegue separar com facilidade os dois idiomas, assim como Jaime.

As breves interações de Damião eram seguidas, após retomarmos a caminhada, por comentários sobre a pessoa com quem ele havia interagido, principalmente quando se tratava de algum outro mineiro aposentado, ou ainda imigrante português. Em geral sabia há quanto tempo estavam aposentados, se estavam doentes, a gravidade dos problemas respiratórios e o lugar de Portugal de onde provinha cada um.

No mais, as referências espaciais de Damião eram variadas, mas sua ênfase recaía sobre todo ponto que pudesse remontar algo sobre o passado minerador do local. Talvez porque seu interesse em contribuir com a pesquisa condicionou seus apontamentos, mas fato é que apontou durante as andanças as antigas pensões onde se hospedou. Foi minucioso ao indicar separadamente aquelas em que meu pai também se hospedara. A 
interação durante nossas caminhadas, portanto, foi preenchida pelos enunciados constituídos tanto pelos passos quanto pelas falas, como atos interessados em produzir uma representação singular do espaço, atravessada por experiências e usos, e que por isso se comunica por meio de signos da paisagem urbana. Como destaca mais uma vez Certeau, é possível, por meio desses enunciados pedestres, desvelar os "tipos de relação que [se] mantêm com os percursos" (Idem: 166) ${ }^{93}$.

Além do mais, Damião tinha especial preferência pela porção mais antiga da cidade. No entanto, na porção de construções mais recentes, ele procurou indicar espaços de concentração de novos grupos imigrantes, principalmente orientais, que ele designava como "chinos" 94 . A conversa que se estendia pelo caminho era quase confessional. Entremeando memórias do sofrimento anterior à migração, Damião parecia acercar de sentidos sua permanência na mineração. Quase sempre que eu pedia a ele que narrasse algo sobre seu tempo na mineração, Damião carregava um tom nostálgico que pretendia impressionar, acentuando a voz e utilizando expressões que denotassem o grande volume da migração décadas atrás.

Os circuitos que percorremos, todavia, tinham sempre um ponto comum de passagem: um miradouro de onde observávamos um vale e onde Damião procurava apontar a direção em que estavam as minas em que trabalhou. Poucos dias depois dessas caminhadas pela cidade, andamos também por trechos afastados e ermos até as antigas entradas de minas abandonadas ${ }^{95}$.

É importante destacar ainda que, mais do que uma identidade profissional para aqueles que trabalharam na mineração, essa atividade econômica marcou também a maneira como a própria cidade se representa. Ademais, nesse ponto notei que o passado minerador da cidade permanece não só na memória de seus trabalhadores aposentados, mas em monumentos erguidos em homenagem a esse passado recente. Num largo ao

93 Os relatos sobre o espaço produzidos ao longo dessas caminhadas podem ser tomados como registros de interações e apropriações diferenciadas do meio material. São formas de descrever as inscrições que a estrutura espacial grava na memória, ou melhor - já que a lembrança não é um ato passivo - de afirmar a maneira pela qual os indivíduos percebem "as relações que são estabelecidas entre pedras e homens" (HALBWACHS, 1990:136).

94 Chino era o modo genérico pelo qual Damião e outros agentes locais se referiam aos imigrantes de origem oriental, em geral trabalhadores do comércio.

Descreverei essas outras caminhadas adiante. 
lado desse miradouro, há uma estátua que Damião fez questão de me apresentar desde o início da minha estada no local. Trata-se de uma estátua, alocada em um cruzamento de uma das avenidas da cidade, representando um homem com uniforme, picareta, capacete e lamparina, instrumentos bem conhecidos dos que dominaram o métier da escavação no subsolo.

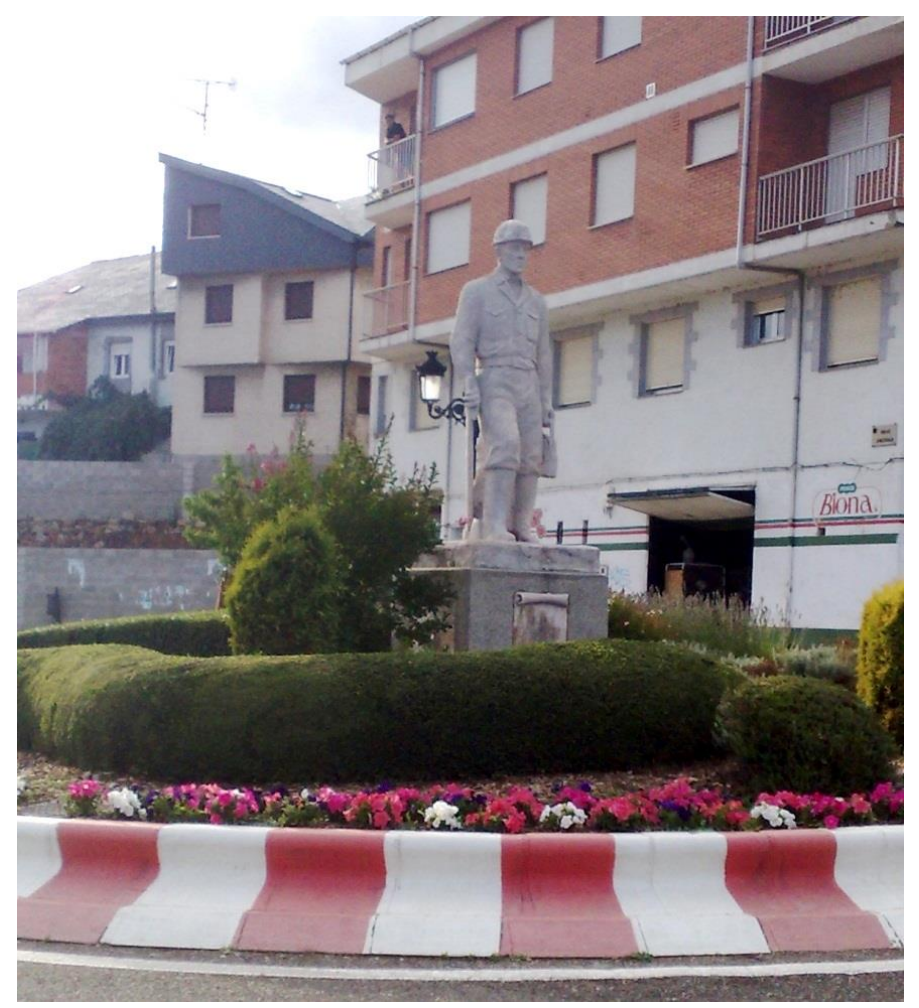

Figura 4. Estátua que homenageia e representa os mineiros em Bembibre

Tanto a estátua quanto a insistência de Damião em mostrá-la indicam a centralidade simbólica da mineração para o imaginário e a memória do contingente migrante português que teve parte significativa de sua trajetória fixada em Bembibre. Isso aponta também para as formas pelas quais a cidade produz imagens e auto-representações, acionando o passado como forma de erigir um imaginário que lhe seja próprio. 
Nesses dias Damião convidou-me também para que visitássemos as minas fechadas. Aceitei de pronto. Imaginei que o cenário desterrado daquele lugar teria algo a dizer. E não estava errado. Fomos eu, Damião e Jaime ${ }^{96}$. Ambos trabalharam na Minex, que primeiro visitamos. Foram colegas de trabalho por muitos anos e já havia muito tempo que não visitavam a área das mineradoras. Foi essa mais uma ocasião de rememoração intensa a partir de referências da paisagem. Ambos narravam o cotidiano e as relações de trabalho daquele espaço.

A maior parte do trecho percorremos de carro, até onde foi possível seguir com o automóvel. Vias estreitas de chão batido permitem-nos acessar de carro as antigas entradas, mas em certo ponto do trajeto só é possível seguir caminhando. Damião e Jaime corroboravam comentários um do outro sobre quão penoso e arriscado teria sido seu trabalho. Jaime aproveitou para descrever um acidente que sofreu e que lhe valeu algumas cicatrizes, que não teve receio de mostrar. Não havia asfalto na maior parte do percurso e logo o único caminho possível passou a ser pelo meio de minúsculos vilarejos aparentemente inabitados, a não ser pela presença de uns poucos moradores em atividades corriqueiras na porta de suas casas. Damião disse que, no passado, a maioria daquelas casas havia funcionado ao menos parcialmente como pensão e foi capaz ainda de identificar algumas.

Quando o caminho ficou estreito demais, tomado pela vegetação, estacionamos e caminhamos um pequeno trecho. A maior parte da estrutura física da mina está preservada. Damião e Jaime identificaram imediatamente o vestiário onde costumavam lavarse depois do dia de trabalho. De fora mesmo tentaram lembrar onde exatamente ficavam seus armários. Enquanto executavam essa relembrança, remontavam ainda a pequenas estratégias de que se valiam para burlar toda a vigilância dos capatazes, descrevendo formas de flexibilizar o ritmo de trabalho. Observamos ainda por entre frestas e fecha-

\footnotetext{
96 Jaime é um dentre os amigos portugueses de Damião. Esses amigos, inclusive Jaime, embora não sejam em sua maioria de Vilas Boas, são em grande parte das vezes de alguma aldeia do nordeste português, o que reforça a hipótese de que um fluxo migratório se configurou de modo mais abrangente para as aldeias daquela região, com possíveis variações e especificidades em cada caso.
} 
duras um galpão onde estavam guardadas máquinas enormes, que não recordaram terem sido utilizadas em seu período de atividade.

Ao serem expostos aos referenciais impostos pela visão da mina frequentada durante tantos anos, foi criado ali um contexto capaz de engendrar a lembrança de modo compartilhado e, mais do que isso, relacional. Como destaca Ecléa Bosi, remetendo ao trabalho de Maurice Halbwachs sobre os aspectos coletivos e sociais da memória, "se lembramos é porque os outros, a situação presente, nos fazem lembrar" (2009:17). Desse modo é factível tomar os aspectos visuais da paisagem como princípios de estruturação da lembrança, tomados como ancoradouro da memória coletiva. Segundo o próprio Halbwachs, o espaço material, com sua peculiar estabilidade, "assegura a permanência de um grupo atual, e o grupo assegura o sentido durável da leitura desse espaço" (1999: 175, tradução minha). A noção de espaço, portanto, é aqui duplamente constituída, como realidade concreta, física, e como resultado da atividade produtiva das práticas contingentes e da memória coletiva ${ }^{97}$.

Observar os instantes de rememoração coletiva foi uma oportunidade de pesquisa que revelou, com fluidez, experiências compartilhadas no passado, sobretudo na infância e na adolescência. Essas lembranças geralmente possuem conteúdo amplamente variável. Podem trazer à tona formas de divertimento e histórias cômicas, ou remeter a perigos e traumas, mas o que importa é que, em geral, não são contadas por uma pessoa só.

Boa parte do terreno das minas estava, no entanto, fechado por portões e cadeados. $\mathrm{O}$ acesso restrito e as estradas estreitas e em parte tomadas pela vegetação limitaram nossa circulação. De longe enxergaram e apontaram o portal por onde desciam às profundezas da mina para o trabalho. Mais uma vez com tom nostálgico bastante enfático, Damião descreveu com admiração o volume de carvão que ele "mal podia calcular" que teria sido extraído daquele lugar.

\footnotetext{
97 Procuro abordar o espaço visto por meio de seus usos e significados, tomado a partir de sua dimensão praticada. Seguindo Michel de Certeau, o espaço “é um cruzamento de móveis. É de certo modo animado pelo conjunto de movimentos que aí se desdobram. Espaço é o efeito produzido pelas operações que o orientam, o circunstanciam, o temporalizam e o levam a funcionar em uma unidade polivalente de programas conflituais ou de proximidades contratuais. (...) Em suma, o espaço é um lugar praticado"
} (1994: 184). 
Recuamos. Cruzamos de volta os pequeníssimos povoados daquela área, e passamos ainda pelas enormes caçambas que transportavam o carvão bruto. Havia ainda alguns montes consideráveis do mineral, acumulados de alguma atividade recente. Jaime e Damião recordaram mais uma vez com expressões muito admiradas o montante de carvão que era extraído e todo o trabalho e maquinário que aquilo demandava.

$\mathrm{O}$ isolamento das minas representa o atual quadro da cidade e o fim de um tempo histórico, tantas vezes descrito por Damião: com a atividade mineradora retraída, Bembibre transformou-se em um espaço de convivência entre aposentados que compartilham em alguma medida um passado comum, marcado pela atividade econômica em torno do carvão. Os entornos das minas estão agora vazios e trazem poucos traços desse passado. A dinâmica migratória teve seu auge em Bembibre, mas hoje se sustenta fundamentalmente por meio da circulação do grupo aposentado que alterna meses entre Portugal e Bembibre.

\section{- 2.3 PARENTESCO E VICINALIDADES: O RETORNO}

Nesse ponto avalio, a partir da relação que estabeleci com Damião, os contextos diversos que permearam sua intenção de retornar a Vilas Boas. A esse respeito é importa dizer que ele afirmou algumas vezes que passou muitos anos sem retornar à aldeia porque "não havia lá nada que [o] fizesse voltar. Sentia-[se] lá sempre deslocado, fora de lugar”. Damião deixou claro que desde a juventude não tinha boas relações com seu grupo familiar. Citou inclusive o desentendimento com seu pai como uma das causas fundamentais de ter decidido emigrar sozinho prematuramente.

Segundo ele, ficou dezenove anos sem voltar a Vilas Boas. No entanto, algum tempo antes da morte de seu pai voltou a frequentar a aldeia. Reaproximou-se dele e recompôs de certo modo alguns vínculos familiares. Além do mais, passou a reformar e recuperar a casa herdada por ele e outros três irmãos conjuntamente. Todos usufruem da 
casa, muitas vezes ao mesmo tempo, enquanto o processo de divisão da herança se arrasta entre conflitos e acordos ${ }^{98}$.

A partir disso, é possível pensar os significados da habitação de caráter familiar, herdada. Podemos mesmo arriscar pensar a casa enquanto "signo". A casa participa com destaque de uma economia simbólica do espaço. A preservação da velha casa dos pais significa também, sempre que possível, a preservação circunstancial do grupo familiar. Presença constante dos relatos de espaço, a casa "é o centro geométrico do mundo" (BOSI, 2009: 356) e constitui um "espaço abstrato estruturado por um sistema de relações não estritamente materiais" (JAISSON, 1999:175-6, tradução minha). Além do mais, a casa é povoada de objetos que nos falam de práticas, que trazem as marcas de quem os manuseou e que suscitam "mais que um sentimento estético ou de utilidade, (...) nos dão ainda um assentimento à nossa posição no mundo" (BOSI, 2009: 360) ${ }^{99}$.

Processos de herança compartilhada são complicados e corriqueiros. No entanto, é sempre ao redor da casa parental (estejam os pais vivos ou seja a casa herdada) que se concentra a reunião familiar durante as festas. Ao reformar a casa herdada dos pais, ao dividir a propriedade com irmãos, ao adquirir um terreno para plantio, ou ainda, como é bastante comum, ao construir uma casa, nova e exuberante, o emigrante compõe o espaço de maneira incisiva. Ainda que a casa seja aberta tão somente de maneira ocasional, por força das festas de verão, das férias, ela é um símbolo material gravado no espaço, na maior parte do ano uma metonímia da família ausente ${ }^{100}$.

\footnotetext{
98 Manuela Ribeiro assinala, a respeito das heranças e partilhas da terra agricultável no nordeste de Portugal, mesmo diante de sua continuada desvalorização, que "são, com efeito, processos para onde converge muito do essencial das expectativas de vida, quer individuais, quer familiares, à volta dos quais tecem múltiplos e complexos jogos de acções veiculadores de interesse variados e, não raro, abertamente antagónicos" (1996: 346). O interesse pelas propriedades se relaciona à dimensão simbólica da posse de uma casa ou terreno. Possuir um terreno onde no passado se trabalhou como empregado para outrem é um signo de ascensão social.
}

99 As casas costumam abrigar também em seus redutos e aposentos histórias sobre quintais, animais e objetos: a roca de fiar trazida das ruínas da casa materna, um santinho recuperado da cabeceira da cama paterna, ou ainda, as ferramentas de trabalho dos pais (a tesoura usada por anos na vindima, o canivete que abria o pão na hora da refeição). Todos esses elementos estão profundamente entranhados de afetos e memórias. 
Ademais, é possível aventar nesse quadro alguma percepção dos vínculos que se concentram no contexto da "casa", aqui percebida como um conceito (LÉVISTRAUSS, 1986; CARSTEN, 2007; PINA-CABRAL, 1986). Janet Carsten sugere que a "casa" é o lugar em que o parentesco é "feito" "por meio do íntimo compartilhamento do espaço, da comida e alimentação" (2007: 37). Por isso é tão importante para o imigrante concentrar a experiência de retorno em torno da casa familiar, como forma de "re-fazer" os laços de parentesco, tão caros à dinâmica transnacional. Com a motivação posta pela casa herdada, Damião reativou laços de sociabilidade e parentesco que passaram a funcionar como chave de acesso, princípio de reinserção no contexto aldeão. Diversos vínculos se refizeram aos poucos e hoje Damião regressa para as festas de agosto e em outras ocasiões "sempre que pode". A família, assim, aparece repetidamente como foco, ora de atração, ora de repulsão, a depender do equacionamento e dos entendimentos produzidos durante o processo de afastamento.

Além do mais, logo que voltou a frequentar a aldeia, um quadro de relações de proximidade e distanciamento se configurou com referência ao passado, à reputação de sua família, mas também com relação ao presente e aos atuais contextos. As relações de proximidade encetadas com Marta e Freitas (vizinhos da casa de Damião na aldeia), por exemplo, se estendem a favores de ordem prática: enquanto Freitas faz uso de um pequeno prédio que pertence a Josefa (para o cultivo de uma pequena horta e produção de alguns itens de consumo cotidiano, tais como batatas e amêndoas), retribui cuidando da casa de Damião, fazendo pequenos reparos ocasionais.

Esse tipo de troca, mais do que de caráter utilitário, é demonstração de um vínculo social produzido e reproduzido de modo intermitente nos intercursos da movimentação migratória, uma espécie de vicinalidade sustentada transnacionalmente pela troca de bens simbólicos incutidos em pequenos favores e presentes ${ }^{101}$. A vicinalidade aqui concebida e abordada refere-se à "vida familiar supradoméstica" vivida essencialmente entre "casas" vizinhas. Assim, a co-habitação constituinte das pessoas no núcleo familiar se completa nos "densos nexos de entre-ajuda vicinal” (PINA-CABRAL, 2011: 1-2).

\footnotetext{
101 Das relações de conflito que produzem distanciamento tratarei adiante, no quarto capítulo, quando abordo o contexto festivo e o que nele é colocado em jogo.
} 
Passados enfim esses dias na Espanha, rumamos para Vilas Boas. Damião tinha intenções de fazer alguns reparos que considerava urgentes na casa herdada de seu pai. A festa se aproximava e Damião disse que era preciso chegar à aldeia com antecedência, já que "nos dias da festa, não se pode fazer nada".

Josefa estava ansiosa para visualizar o santuário de Nossa Senhora da Assunção e para que eu também pudesse fazê-lo. Poder avistar o santuário produz uma sensação de contentamento àquele que deseja chegar à aldeia, já que é a referência de proximidade que se avista à maior distância. Como figura num dos pontos mais altos da região, não demora muito e, entre uma curva e outra, logo se pode avistá-lo há alguns quilômetros da aldeia.

E quão melhor se consegue vê-lo, mais próximo se está da aldeia. Já muito próximos, quando já o víamos do sopé do monte em que se assenta, estávamos às portas de Vilas Boas. Nesse momento em que termina o alcatrão e a estrada segue feita de paralelos realiza-se uma passagem a um território de pertenças, onde o grupo migrante que retorna investe esforços e produz significados e relações - de proximidade, distância, afeto, parentesco, rivalidade e conflito.

A partir daquele momento eu passaria a me aproximar melhor dos sentidos que possui a frase "meu Portugal é a aldeia", dita de modo semelhante por tantas pessoas. Era final da tarde quando chegamos, mas ainda estava bastante claro. Durante o verão português a iluminação solar se estende por parte da noite. Eu olhava em volta os detalhes daquela paisagem estranhamente familiar, próxima e desconhecida. As imensas paredes de pedra, grossíssimas, alguns azulejos na fronte das casas, as estreitas ruas, algumas parreiras aqui e ali. Mas o que mais chamava a atenção era a posição do santuário. De quase qualquer ponto da aldeia podia-se vislumbrá-lo e, da varanda em que estávamos, éramos especialmente contemplados pela vista.

Assim que iniciei o trabalho de campo no espaço da aldeia, construí um conjunto novo de relações que mediaram minha participação naquele contexto. A ambiência do tempo festivo estava em plena ascendência. A análise de toda experiência vivida nas festas que pude presenciar será feita no último capítulo, com especial atenção às especificidades que o tempo de celebração insere no plano das relações. 


\section{CAPÍTULO 3}

\section{“PORTUGAL, TU ME MANQUES" 102; A CIRCULAÇÃO TRANSNACIONAL E O CONTEXTO FRANCÊS}

Neste capítulo a etnografia mais uma vez se desloca para dar continuidade à pesquisa em outro ponto de destacada relevância no plano do campo social transnacional constituído pela dinâmica emigratória aqui enfocada. As práticas e relações descritas se referem agora ao trabalho de campo desempenhado na França, consequência das demandas interpostas pela própria mobilidade dos agentes ${ }^{103}$. Assim como na Espanha, procurei reconstituir pela observação as práticas por meio das quais os agentes produzem o espaço no contexto de destino, atentando para as maneiras que utilizam a cidade em suas atividades cotidianas (sobretudo de trabalho e lazer).

\footnotetext{
102 Traduzida como "Portugal, sinto sua falta", essa frase foi utilizada por Marienne, filha mais velha (nascida na França) de André em seu perfil em uma rede social na internet. Ela é sugestiva porque, dita em francês, comunica a todo francófono sentimentos de saudade e nostalgia com relação a Portugal e, de certo modo, afirma um pertencimento. André, referido inicialmente no primeiro capítulo, assume agora um papel central de mediador para a pesquisa, tal como descreverei adiante.

103 Tal como indica George Marcus, o exercício de uma etnografia multi-localizada pode decorrer em deslocamentos na persecução dos agentes através de fronteiras. Em suas palavras, "a etnografia móvel toma trajetórias inesperadas ao rastrear formações culturais através e dentro de múltiplos locais de atividade" (2005: 80, tradução minha).
} 
A França abriga o maior contingente imigratório português entre os diversos destinos para os quais a diáspora se deslocou. A França era o destino comum, onde mais consistentemente se constituía uma estrutura de acolhimento que ajudou a esboçar as linhas do campo social transnacional em processo. Segundo dados do recenseamento populacional de 2010 do Insee, o número de imigrantes portugueses está próximo dos quinhentos e noventa mil ${ }^{104}$. Além de numerosa, a imigração portuguesa na França é antiga e, também por isso, consolidou uma ampla estrutura de acolhimento formada pelo contingente estabelecido e que inclui o comércio especializado em produtos de origem portuguesa, centros de cultura e recreação, além de vizinhanças quase inteiramente constituídas por famílias imigrantes.

Por esse modo, a França figura enquanto polo de destinação durante muito tempo preferido pelo enorme grupo que deixou Portugal, sobretudo a partir de meados da década de 1940 e princípio da década seguinte (SANTOS, 2010: 215; BAGANHA e GOIS, 1998: 235; SCOTT, 2010: 152; SERRÃO, 1985: 999). Considerando o enfoque priorizado, desempenhar parte da pesquisa nos espaços de circulação do subúrbio parisiense implica em considerar as inúmeras formas pelas quais os migrantes mantêm vínculos afetivos e sociais ao recriarem formas sociativas que alimentam o trabalho de reinvenção dos laços de pertencimento e das relações distendidas transnacionalmente.

\section{- 3.1 "FOLLOW THE PEOPLE" II: PELA FRANÇA}

Conheci André durante meu primeiro período em campo. Durante o trabalho cotidiano de observação fui a ele apresentado por Lúcia e João ${ }^{105}$. André é pouco mais

$104 \quad$ Esses dados do Insitute National de la Statistique et des Études Économiques (Insee-FR) sobre a população imigrante no país não leva em consideração os filhos de emigrantes nascidos em território francês. Estão considerados nesse número apontado apenas os residentes na França, mas nascidos em Portugal. Essa cifra representa 10,7\% do total de imigrantes nascidos fora do país. Para acesso aos dados, consultar http://www.insee.fr/fr/themes/tableau.asp?ref id=immigrespaysnais (consultado pela última vez em 09/09/2013).

105 Lúcia é a irmã mais jovem do meu pai, minha tia. João é seu marido. Nunca antes da pesquisa eu havia os conhecido. No entanto, as relações construídas em campo fizeram deles importantes mediadores da pesquisa para o acesso a diferentes espaços da aldeia, bem como para a formação da rede mais ampla de colaboradores que passaram a integrar de modo mais constante o trabalho. Desenvolvo mais 
velho que Lúcia e as famílias de ambos têm uma proximidade antiga. Depois de termos nos conhecido durante minha primeira etapa de trabalho de campo, André convidou-me para que eu, em oportunidade futura, fosse conhecer o lugar onde ele e outros portugueses vivem na França. Após termos nos conhecido em Portugal e muito conversado sobre suas experiências e concepções sobre a emigração, fui por ele convidado para conhecer sua casa e vida na França. Foi desse modo que expandi a pesquisa até o subúrbio parisiense, onde realizei parte destacável do segundo período de pesquisa em campo.

André vive em Goussainville, um bairro do subúrbio parisiense, ao norte da capital francesa. Desde que nos encontramos pela primeira vez em Paris, André atuou como mediador da pesquisa, um colaborador-chave de todo trabalho desempenhado na França. Ademais, sua centralidade como interlocutor da pesquisa se constitui porque, entre outros fatores, manifestava sempre de modo reiterado formas de atestar seu vínculo e identidade com Vilas Boas. Isso se comprova pelo fato de ter destacado, ao narrar aspectos de sua trajetória, seu empenho constante em se ligar à aldeia. Em certo momento afirmou que, ao longo das já quase duas décadas que vive na França deixou de ir a Portugal no máximo duas vezes, de modo que em todas as outras oportunidades fez questão de realizar seu retorno anual, ainda que em algumas dessas vezes tenha podido ficar menos tempo que de costume.

Goussainville situa-se no departamento de número 95, de Val-d'Oise. Trata-se de um bairro fundamentalmente residencial antigo, na região da Île-de-France. É atravessado ao meio pela linha férrea do transporte público, o que demarca uma cisão no lugar entre a porção antiga e histórica, e a porção mais recente e habitada. André vive em um quartier ${ }^{106}$ novo, considerado recente, construído a partir dos loteamentos promovidos nas antigas propriedades agrícolas nos anos 1960. De topografia plana, as casas seguem ali uma arquitetura harmoniosa e atendem a um padrão quanto à fachada, de modo que têm todas muros e portões frontais muito similares.

Diferentemente de Damião, André não se antecipou às minhas questões, expondo de modo franco e sistemático uma história de vida elaborada, encadeada e minuciosa. Conheci sua trajetória através de elementos que pude coletar no decorrer do tempo

propriamente a apresentação de ambos e a descrição e análise da tarefa de mediação executada principalmente por João no capítulo seguinte, em que trato da festa e do período de pesquisa executado na aldeia, após acompanhar diferentes grupos migrantes em suas viagens de retorno a Portugal.

106 Os quartiers franceses são as menores unidades administrativas que compõem a cidade, o nível local da participação política e do uso do espaço público. 
em que convivemos, nos dois períodos em que realizei de trabalho de campo, sobretudo durante a etapa da pesquisa realizada na França.

Importa começar dizendo que André destaca em sua trajetória o fato de ter emigrado sozinho. Não foi acompanhado de familiares, não foi precedido de ninguém. Recebeu apenas algumas parcas indicações de colegas do período em que serviu à marinha, mas gosta de dizer que construiu um percurso na França bastante independente do auxílio de terceiros. Ele sustenta um discurso bastante insistente sobre o valor da "independência" que seu trabalho lhe proporciona, e esse aspecto de suas falas muito constantemente se relaciona a aspectos de sua história de vida, que ele recupera oportunamente para ilustrar seus comentários ${ }^{107}$.

Quando no final da adolescência rumou para Lisboa para cumprir o serviço militar na marinha portuguesa, cogitou por longo tempo seguir carreira militar. Ainda hoje possui na decoração da sala de estar de sua casa fotografias fardado em navios de guerra. Antes de ir a Lisboa e passar o período determinado no serviço militar, chegou a experimentar alguns meses de emigração na França, para onde retornou assim que concluiu os serviços militares e decidiu definitivamente que não seguiria tal carreira.

Desde sua ida definitiva para a França passaram-se dezenove anos. André tem quarenta anos e quase metade de sua vida passou na França, onde trabalhou e viveu em diversos lugares até se estabelecer em Goussainville, onde comprou sua atual residência. Ele e sua esposa, Laura, contaram que antes de comprarem sua casa tiveram ajuda de algumas pessoas, tais como um antigo patrão português que lhes proporcionou moradia sem que tivessem que pagar renda ${ }^{108}$ por ela. Isso permitiu que pudessem mais rapidamente comprar sua casa própria na França.

Laura também é emigrante portuguesa, proveniente do noroeste de Portugal, da região do Minho, fronteiriça com a região de Trás-os-Montes. Pouco mais jovem que André, Laura contou que eles se conheceram em uma "discothèque" (discoteca) muito frequentada por jovens imigrantes portugueses, fato que me fez pensar em certo padrão de nupcialidade. Assim como Damião, que antes de se unir a Josefa foi casado por um longo período com outra portuguesa, imigrante na Espanha, outros muitos imigrantes casaram após emigrar e conheceram seus parceiros, todos imigrantes portugueses, nos

\footnotetext{
107 Isso se relaciona aos valores associados aos objetivos da emigração. Esse aspecto também foi notado e comentado no caso de Damião, conforme descrito no capítulo anterior. 
contextos de destino. Penso que isso se deve a um tipo marcado de circulação dos imigrantes pelos espaços sociais. Quero dizer que é comum que convivam intensamente em locais tipificados tais como os ambientes de trabalho, moradia (vizinhanças) e lazer (centros culturais, casas noturnas, etc.). Essa observação dá indícios dos modos pelos quais o grupo migrante espacializa o contexto de destino, apropriando-se de um uso específico da cidade que procurei aventar.

Além disso, também convém dizer de antemão que André desempenhou um papel de colaborador-chave para a pesquisa, haja vista seu discurso engajado, bem como seu esforço continuado para demonstrar uma forte conexão social e sentimental com a aldeia. Atualmente é responsável por um chantier ${ }^{109}$ de reciclagem de metais (ferro, alumínio, cobre e outros). Seu patrão, proprietário do mesmo, é também português e todos os seus colegas de trabalho são imigrantes das mais variadas origens (entre outros portugueses, turcos e de países da Europa do leste), o que é sinal da grande e variada população imigrante na França.

Pouco depois que cheguei, André tratou de apresentar o bairro e explicá-lo para mim. Disse que o lugar é tranquilo e repleto de imigrantes, boa parte dos quais são portugueses. Por fim, disse ainda que na mesma vizinhança, não muito longe de sua casa, moram outros imigrantes de Vilas Boas que ele conhece e que gostaria de me apresentar. No caminho até sua casa, ele decidiu circular brevemente pelo local para apontar onde mora cada um dos migrantes por ele citados. Referiu-se a eles nessa ocasião remetendo às suas respectivas famílias, procurando gerar um conjunto de referências que ajudasse a situá-los no contexto aldeão, bem como no campo transnacional. Acordamos que, assim que possível, encontraríamos com os demais provenientes da aldeia.

Portanto, nas palavras dele, Goussainville é "um bairro de imigrantes". Uma breve caminhada pelo lugar pode revelar de modo superficial essa diversidade cultural concentrada. Tal diversidade é algo bastante comum para o subúrbio parisiense, mas é importante dizer que Goussainville se tornou um lócus importante de concentração de imigrantes portugueses e, ao perseguir uma rede de relações, concluí que se trata, sobre-

109 Chantier pode ser traduzido literalmente como "local", mas é também o termo nativo utilizado para se referir aos canteiros e espaços de trabalho, que no caso de André são os grandes galpões de compra, pesagem e separação de metais descartados para reciclagem e reaproveitamento. São diversos os termos em francês que permeiam as falas dos emigrantes radicados na França. São, em geral, termos utilizados no cotidiano de trabalho e para os quais não conseguem encontrar equivalente perfeito e imediato em português. 
tudo, de um importante polo para a pesquisa, já que converge um número significativo de agentes e relações que passam antes por Vilas Boas.

\section{Relações e Contexto}

Quando cheguei pela primeira vez à casa de André, algumas pessoas nos esperavam para uma refeição. Eram Laura, Dênis, amigo da família, e Ivan e Carla, casal brasileiro ${ }^{110}$ vizinho. Desde esse momento passei a notar que ali se apresentaram as relações que iriam estruturar as observações da pesquisa. A refeição, preparada por Dênis, se deu no quintal da casa de Ivan, colada à casa de André. Foi bastante animada, e também a primeira ocasião em que fui perguntado e pude expor minhas intenções de pesquisa no lugar.

Enquanto nos apresentávamos e conversávamos, dados importantes para o mapeamento daquele contexto se apresentaram em meio ao diálogo, principalmente no que concerne ao aspecto de cada uma das relações que constitui o grupo ali reunido. A esse respeito é importante destacar desde já que André e Laura são padrinhos da filha recémnascida de Carla e Ivan. Carla era naquele momento recém-chegada na França. Já Ivan imigrou alguns anos antes e por algum tempo enviava parte do dinheiro que ganhava para Carla (ainda hoje envia dinheiro, mas uma quantia menor, como auxílio aos familiares que estão no Brasil). Ivan é "maçon" (pedreiro) e vive com a família no que costumam chamar de "studio", uma pequena casa de cômodo único que serve simultaneamente de sala de estar, cozinha e dormitório, com um banheiro anexo. Esse tipo de moradia é comum nos bairros do subúrbio. São os modelos com os menores valores de aluguéis e atendem às demandas dos imigrantes, principalmente os recém-chegados.

Dênis, por sua vez, é um rapaz de dezenove anos, também imigrante português da região nordeste do país, muito próximo do grupo familiar de André e por vezes considerado um parente. Dênis vive com seu irmão mais velho (que foi quem intermediou

110 Apesar da pequena quantidade de imigrantes brasileiros, é possível constatar uma espécie de relação de proximidade entre portugueses e brasileiros. Além de Ivan e Carla, André relatou as boas relações que tinha com uma família brasileira ex-inquilina sua e que vivia na edícula de três cômodos nos fundos de sua casa. Essa proximidade notada entre os dois grupos falantes do mesmo idioma não é constatada com outros grupos imigrantes. 
sua ida para a França) em Goussainville, e trabalha em um ramo da construção civil, em uma empresa que instala janelas e vidros em geral, propriedade de um senhor também imigrante português. Segundo contou Dênis, ele e seu irmão haviam sido vizinhos de André quando se conheceram. André disse certa vez, a respeito de sua relação com Dênis, que o considera como uma espécie de filho mais velho. Aqui é importante atentar preliminarmente para os modos de engendrar o parentesco também por meio de formas de "consideração", estima.

Já as filhas e o irmão de André foram para Portugal antecipadamente. Acompanharam outro grupo de portugueses que ia para uma aldeia próxima. Isso é bastante frequente como uma prática de prestação de favores e contra-favores. Essas caronas ora são vendidas, ora são trocadas. André conhece grande parte dos portugueses que habitam a região, e essa proximidade com outros imigrantes acaba por constituir um pequeno circuito de troca de favores por onde circulam, entre outras coisas, pessoas, bens, informações, recados, cartas, fotos, dinheiro e bagagens. Esse circuito de encomendas e favores é uma espécie de "economia do retorno": como os imigrantes costumam saber das férias e viagens de retorno uns dos outros, prestam-se esse tipo de auxílio corrente.

Como Laura e André ainda não estavam de férias, só pude acompanha-los em determinadas ocasiões: ou após retornarem do trabalho no meio da tarde, ou mesmo nos seus locais de trabalho em dias determinados, combinados com antecedência. Além disso, em algumas dessas ocasiões circulei com Laura pela cidade e pude acompanhá-la de seu local de trabalho até sua casa, notando alguns de detalhes de sua relação com a cidade. No mais, o tempo restante despendi interagindo com esses outros atores, importantes colaboradores do contexto observado nos espaços percorridos. No trecho a seguir busco descrever as interações que se desenrolaram nos diversos espaços em que pude acompanhar e observar sobretudo práticas de sociabilidade dos agentes.

- 3.2 "PARA MELHORAR A VIDA": O DISCURSO E AS PRÁtiCAS DOS MIGRANTES

Goussainville é marcada, portanto, pela presença notória de um grande e variado contingente imigrante. Importa, no entanto, discutir aqui a forma específica pela qual a 
parcela desse contingente constituída por portugueses e seus descendentes se insere e produz determinados espaços por meio de usos determinados do espaço urbano.

Produção de localidades: práticas e representações

As oportunidades de observação que se configuraram na França são significativas para reflexões a respeito do modo de vida produzido pelo grupo emigrante radicado no subúrbio parisiense. Alguns elementos ganham destaque sobretudo em espaços de convivência entre imigrantes. Adiante procuro elencar esses espaços e descrever as situações nele encetadas.

A casa e suas extensões

A casa é ela mesma um dos principais espaços de convivência e sociabilidade dos imigrantes. Repleta de significados, produzida e pensada conforme seus usos, é um ambiente de acolhimento e onde se explicitaram mais constantemente as relações de proximidade $^{111}$.

A casa de Laura é André não foge a essa característica. Diversos elementos e pequenos detalhes da decoração da casa indicam esse investimento simbólico no espaço de habitação. São ferramentas de madeira comuns entre camponeses (tais como ancinhos e rastelos), envernizadas e cuidadosamente posicionadas em vasos cerâmicos rústicos, socas ${ }^{112}$ de madeira decoradas e envernizadas, fotos de família, trigo seco, bonecos bibelôs com trajes tipicamente camponeses (representações estereotípicas), além de

111 Aqui a casa se apresenta como uma dimensão analítica significativa e passa a ser também o suporte material de um conjunto de relações constitutivo dos grupos migrantes, onde se explicitam as proximidades e se produz de modo mais efetivo o parentesco. A casa, por sua vez, é a "entidade centralizadora de relações de um casal" (MACHADO, 2010: 10) ou da família de modo mais abrangente. Essa noção de casa remonta às elaborações de Claude Lévi-Strauss (1986 [1984]) e se fixa em uma tradição de análise que passa também por João de Pina-Cabral (1986) e Janet Carsten (2007), entre outros.

112 Socas são calçados de madeira tidos como artigos "tradicionais" e muito comuns nos trajes de grupos de dança folclórica ou como elementos decorativos de cômodos da casa. 
uma videira meramente ornamental nos fundos do quintal, ao lado da horta de uso cotidiano. Na televisão, pouco utilizada, viam-se tão somente os canais portugueses sintonizados pelo serviço de assinatura.

Há ainda na parte traseira da casa uma outra moradia térrea que estava alugada a um casal português advindo de Lisboa. Havia entre inquilinos e locadores uma relação de proximidade. Interagiam constantemente, sobretudo no espaço comum do quintal. Dividiam refeições, mas principalmente conversas ${ }^{113}$. Como Iara e Lucas são mais jovens, bem como chegaram mais recentemente à França, é comum ocorrer que André e Laura lhes ofereçam conselhos corriqueiros, fortuitos, entremeados às conversas ${ }^{114}$.

Nesse momento se destaca um discurso sempre reforçado sobre o comportamento esperado de um imigrante que procura ascender social e economicamente. Uma espécie de conduta moral é pensada e prescrita como ideal para que o imigrante seja capaz de atingir seus objetivos em contexto estrangeiro, o que inclui um estilo de vida comedido e regrado, acompanhado de grande empenho no trabalho. Paradoxalmente, nas refeições em conjunto há um discurso de estímulo ao consumo e à saciedade (frases como “como o quanto queiras!" ou "aqui não há miséria!” são comuns). Isso porque um conjunto complexo de valores acompanha a alimentação, momento carregado de simbologias sobre a fartura, valorizada como signo fundamental do sucesso obtido na empreitada emigratória vivida.

A casa de Laura e André constitui, desse modo e em certa medida, uma espécie de centralidade para o grupo que se concentra em Goussainville, entre outros motivos, por sua precedência no lugar. Centralidade é uma noção que aponta para as formas, de certo modo competitivas, pelas quais um grupo familiar busca se tornar o vértice de um conjunto significativo de relações. Adoto, destarte, uma compreensão ampla da noção de família, que apreende não apenas as relações consanguíneas como constitutivas do grupo familiar, mas também inúmeras relações de proximidade, fundamentais para a

113 Assim como sugere Comerford ao analisar as conversas no contexto rural que pesquisou (2003: 89), é importante notar que tipo de relação modula essa interação. No caso aqui observado, entendo que houve uma espécie de diálogo que colocou em jogo os saberes que constituem a migração como um saber prático. Nesse sentido, André assumiu uma posição central e fez de Lucas e Dênis ouvintes que interagiam mais esporadicamente na conversa. Essa quase hierarquia se constitui em algumas ocasiões e em geral respeita o tempo e o sucesso de cada interlocutor em sua trajetória migrante, medido em geral por sua atual situação econômica. 
percepção do grupo familiar, o que pode incluir, entre outros, relações de vizinhança, amizade e diversas modalidades de apadrinhamento. Recupero para isso Janet Carsten quando afirma que "o parentesco é feito na casa por meio do íntimo compartilhamento de espaço, comida e cuidado que se passa no espaço doméstico" (2004: 35, tradução minha).

A emigração, portanto, representa para o contingente aldeão o modo mais eficaz pelo qual os grupos migrantes podem produzir e reproduzir suas próprias relações ao longo de suas trajetórias. Isso, no entanto, não indica uma descontinuidade forte com relação ao grupo familiar que permanece na aldeia, mas um processo de rápida reconfiguração das relações de parentesco, inclusive através de fronteiras nacionais e para além de laços de consanguinidade. Entendo que a criação de novas centralidades não implica invariavelmente em desvinculações, mas produz múltiplas filiações e um jogo relacional.

A centralidade constituída em torno da casa de Laura e André se deve em parte ao fato de André ter servido de mediador de grande parte dos demais imigrantes provenientes de Vilas Boas. Pedro e seu sogro, o senhor Joaquim, vieram recentemente para a França e, segundo eles, Pedro tinha emprego assegurado antes mesmo de chegar ${ }^{115}$. O mesmo se passa com Bernardo, que recebeu incentivo e orientação de André para que comprasse sua residência em Goussainville ${ }^{116}$. No entanto, a despeito da posição de André e Laura nessas relações, todos se prestam visitas constantemente, como forma de reforçar os vínculos e, ao mesmo tempo, atualizá-los. Todos se envolvem no esforço continuado de produzir as relações, a proximidade e modular possíveis tensões, desentendimentos e conflitos.

\footnotetext{
115 Pedro tem aproximadamente a mesma idade de André e também trabalha em um chantier de reciclagem, emprego que André lhe ajudou a conseguir. O senhor Joaquim, por sua vez, é mais velho (é sogro de Pedro), tem por volta de sessenta anos, e trabalha ainda como maçon (pedreiro). Ambos são amigos de André desde muito antes de imigrarem, quando viviam na Ribeirinha, aldeia menor da freguesia de Vilas Boas.

116 Bernardo também trabalha como maçon na construção civil. Ainda estava em processo de conclusão da construção de sua casa, bastante próxima da casa de Laura e André. Esses dados de campo se revelaram sobretudo em situações de visitação à casa dos demais imigrantes. Tais situações serão também descritas adiante nesse mesmo capítulo.
} 
Ademais, é no espaço da(s) casa(s) que se realizam algumas práticas que reconduzem a uma representação do passado ${ }^{117}$. Penso em pequenas práticas cotidianas de experiência do espaço no contexto de destino que criam a possibilidade concreta de sustentar, por meio de atos criativos, traços diacríticos que envolvem a invenção de um imaginário ligado ao passado aldeão, rural. Refiro-me sobretudo aos espaços anexos da horta, da adega e do jardin ${ }^{118}$.

Um trecho do quintal é reservado ao plantio, a uma pequena horta de uso diário. Trata-se de um trecho não cimentado onde a terra aparente é cuidada e cultivada. Nesse pequeno trecho a família produz uma horta de onde retiram parte de sua alimentação rotineira, em geral batatas, cebola, temperos e hortaliças. Produzir esses itens revela em alguma medida a escolha de um padrão alimentar associado aos modos de alimentação portugueses e, mais propriamente, aldeões. Quando perguntei a Laura sobre suas escolhas alimentares, ela respondeu da seguinte maneira:

Olha, aqui ainda comemos como antes, como comíamos em Portugal. Até que aprendi a comer como os franceses, aprecio alguns queijos deles e coisas assim. É parecido, mas não é a mesma coisa. Prefiro ainda as batatas com o azeite como eram e, agora que podemos, um bom pedaço de carne.

Está, portanto, entremeada às refeições um conjunto de significados e valores. Por um lado, alguns alimentos assumem o papel de caracterizar escolhas capazes de

\footnotetext{
117 Essas atividades cotidianas descritas por Michel de Certeau como “(...) mil práticas pelas quais usuários se apropriam do espaço organizado pelas técnicas da produção sócio-cultural" (1994:41) foram pensadas por Feldman-Bianco na observação da imigração portuguesa para New Bedford, nos Estados Unidos. A descrição é especialmente sugestiva: “(...) no espaço privado destas casas imigrantes, o upstairs (andar superior) tende a concentrar símbolos do consumo americano (...). Em contraste, o downstairs (térreo), incluindo o quintal, representa a reconstrução da memória (utópica) da vida vivida nas aldeias e cidades açorianas" (1995:98).

118 Jardin, literalmente traduzido como "horta", é o termo francês utilizado pelos agentes como referência aos terrenos fora do espaço urbano, em geral alugados, para finalidades de plantio e lazer. Esse espaço é tomado aqui como uma das extensões da casa, para onde se prolongam parte das relações e interações próprias à casa.
} 
produzir identificações em torno da prática alimentar em família, conjunta. São tidos, além disso, como pequenos presentes trocados a fim de uma vez mais expressarem-se vínculos e proximidades, alianças que estruturam o grupo. As batatas são arrancadas, limpas e armazenadas em grandes sacos de estopa, próximas à lenha. As cebolas são colhidas e dispostas em um espaço na adega, subterrâneo da casa, onde podem secar e são depois trançadas. A adega guarda, além das cebolas, uma quantidade razoável de vinho e azeite trazidos de Vilas Boas, também oferecidos por amigos e parentes.

Há ainda que se destacar o caráter comensal altamente valorizado nas ocasiões de encontro familiar. As refeições são compartilhadas não apenas na cozinha, mas no quintal, onde costumam se reunir ao redor de uma grelha de metal utilizada para assar grandes peças de carne bovina e suína. Essas são também situações recorrentes em que são elaboradas e enunciadas compreensões sobre a imigração. Emerge com força e ênfase um discurso que salienta o aspecto funcional da prática imigratória, o que se explicita quando André explica que seu afastamento da aldeia foi "para melhorar a vida", ou seja, imprime em sua trajetória uma dimensão forçosa. Dênis acrescenta a isso certo remorso de sua parte, ao dizer que

se soubesse o que é a vida na França não tinha emigrado. No campo vive-se bem: não temos muito, mas nunca falta o que comer. Já muitos trabalham aqui [na França] porque em muitas partes não há alternativas: ou é isso, ou nada.

O entendimento produzido no contexto das refeições ajuda, portanto, a constituir as interpretações nativas sobre a imigração, suas causas e características. Esse discurso do migrante sobre a imigração surge sobretudo nos diversos contextos de sociabilidade. Não somente o parentesco se exprime segundo uma visão nativa configurada pelas contingências das trajetórias e contextos migratórios, mas nessas ocasiões a própria migração é provida de significações. Um grande esforço interpretativo é exercido para incluir a migração como um evento prático inserida em uma ordem lógica de fatores. Um tom fatalista impregna as falas, dando à imigração uma condição por um lado repleta de tensões, contradições, feita em grande medida à contragosto mas, por outro, a melhor dentre as perspectivas, capaz de incluir a aldeia em uma dinâmica sistemática. A maior das 
contradições se revela no fato de a imigração produzir uma descontinuidade e impor demandas de recriações (do parentesco, das relações, etc.) que têm, no final das contas, o intuito maior de produzir continuidades significativas (do pertencimento, das práticas, etc.). Toda a angústia associada às representações acerca da imigração e às incertezas e agruras da trajetória migrante repercute em um discurso que enaltece o esforço de quem migra e busca produzir um re-sequenciamento nas narrativas e subjetividades, cindidas em alguma medida pela migração.

Por fim, os finais de semana foram de destacada importância para a observação de momentos de sociabilidade, sobretudo o domingo. Pude acompanhar alguns contextos de lazer fortemente marcados por modalidades de interação pautadas pela comensalidade. Ocupado parcialmente com os preparativos para a viagem, o último fim de semana antes do retorno é o exemplo mais icônico. Naquela ocasião Laura e André convidaram alguns amigos portugueses ${ }^{119}$ para um almoço em um terreno que alugam nas margens de Goussainville e que costumam chamar de jardin.

O terreno não é grande, situado em zona erma, em meio a uma estrada de terra batida. O terreno é compartilhado por algumas famílias, cada uma das quais cultiva um trecho, o que não impede que troquem alguns dos itens cultivados. Assim que chegamos, ajudei Laura a colher algumas cenouras e pimentões. Colhemos depois abóboras, que ela precisou ensinar-me o modo correto de fazer, bem como quais eu deveria colher e quais eu deveria deixar para que se desenvolvessem ainda um pouco mais. Enquanto eu colhia as abóboras, Laura seguiu limpando o terreno, arrancando as ervas-daninhas que cresciam em meio aos canteiros cultivados.

Além da lida com terra, no jardin constitui-se um espaço de interações mais uma vez em torno das refeições. Almoçamos ali entre conversas e risos, por meio dos quais circulava uma grande quantidade de troca de informações sobre as viagens de retorno a Portugal a serem realizadas em breve. Todos sabiam de que lugar de Portugal eram os demais e isso era motivo de comentários, mote para a brincadeira, a interação jocosa e as provocações de cunho regionalista em uma espécie de interação permeado por diferenciações, ainda que de modo inegavelmente amistoso.

119 São todos ex-colegas de trabalho de Laura, imigrantes também vindos de aldeias da porção norte do país. 
A vizinhança

André afirmou conhecer todos os portugueses de Goussainville advindos de Vilas Boas. Disse com certo orgulho ter sido um dos primeiros da aldeia a se estabelecer naquela vizinhança ${ }^{120}$. O único que, segundo André, foi capaz de comprar uma residência no local há mais tempo foi Francisco, aldeão de uma conhecida família da aldeia dispersa pela migração.

André foi capaz de enumerar cada um dos emigrantes originários de sua aldeia, discriminando em que trabalham, há quanto tempo estão na França e, caso possuam uma, há quanto tempo têm casa própria. Ademais, André sabe também quem são e onde moram boa parte dos demais portugueses de seu quartier. Segundo André, ele reside ali já há tanto tempo que conhece e se relaciona há algum tempo com os portugueses da região, em sua maioria no âmbito das casas de cultura e associações culturais da região, presididas e frequentadas por moradores do local ${ }^{121}$.

Quando voltamos do jardin, Laura preparou algumas sacolas que fomos depois oferecer à esposa de Bernardo em uma visita. Fomos recebidos inicialmente na cozinha, que mais uma vez emerge como espaço significativo de interações. Tomamos café com a família de Bernardo, que estava reunida ${ }^{122}$, além da coincidente visita do senhor Joaquim. Após o café, Bernardo nos levou para conhecer sua casa, ainda grande parte em construção. Esse breve passeio pelas acomodações da casa de Bernardo terminaram na garagem, onde fez questão de mostrar sua moto, repleta de adesivos da bandeira de Portugal e que ele pretendia levar para a aldeia. Nesse momento foi que André pediu ao senhor Joaquim que fosse com seu genro, Pedro, ajudá-lo a fazer a instalação elétrica de uma carroceria de reboque que havia comprado para também poder levar a Portugal

\footnotetext{
120 Há uma série de valores associados à posse de uma casa, principal objeto de desejo de grande parte dos imigrantes portugueses. André chegou a revelar que, em sua concepção, a casa é o que há de mais importante para o imigrante e que todo aquele que prioriza a compra de outros itens é "tolo".

121 O papel das associações será descrito mais adiante, bem como algo sobre as relações e práticas dos emigrantes produzidas no âmbito desses locais.

122

Os sogros de Bernardo vivem com ele e sua esposa na França e ajudam a criar seus filhos.
} 
uma moto recém-comprada. Acordaram que se encontrariam na casa de André dois dias antes da viagem, que ocorreria no meio daquela semana ${ }^{123}$.

As visitações ${ }^{124}$ constantes entre esse grupo são formas de prestações e contraprestações, representam dádivas no sentido proposto por Marcel Mauss (2003). Ademais, envolvem outras formas de trocas, sobretudo favores mutuamente prestados e requisitados. Visitar alguém e retribuir a visita são formas de explicitar e reiterar vínculos sociais, do mesmo modo que convidar e ser convidado, receber e acolher alguém. Nesse sentido é de suma relevância destacar como o grupo português imigrante exalta sua proximidade, sua sociabilidade, por vezes em oposição ao recato dos vizinhos franceses que, nas palavras de Laura, "ninguém vê quando chegam nem a hora em que saem de casa" ${ }^{125}$. De forma semelhante, André procura sempre destacar a duração de algumas

123 No entanto, em torno das expectativas que cercam as trocas de favores estabelece-se certa tensão, parte importante dessas relações. André, por exemplo, manifestou algumas vezes sentir que Pedro e Joaquim lhe devem certa gratidão em virtude de tê-los ajudado no processo de fixação e adaptação na França. Nisso consiste sua expectativa de perceber neles uma disposição constante para ajudá-lo em pequenas tarefas. Essa expectativa foi frustrada algumas vezes: primeiro quando Pedro disse que não poderia levar Dênis a Portugal a pedido de André porque seu carro não teria espaço, e uma segunda vez quando o senhor Joaquim não pôde auxiliá-lo na montagem do reboque que utilizou para transportar sua nova motocicleta para Portugal. A respeito desses eventos, André manifestou descontentamento, entendendo como "falta de consideração".

124 Essas visitações são importantes maneiras de reforçar o vínculo entre o grupo. Por isso cabe lembrar que André citou ainda suas visitas, em outros momentos mais constantes, a outros grupos de amigos imigrantes, também provenientes de Vilas Boas, mas que moram mais longe, em outros distritos e regiões da França. Citou ainda as visitações mais ocasionais ao grupo que vive na Suíça do qual faz parte uma irmã sua. Essas visitações explicitam vínculos transnacionais que fazem parte do mesmo campo social ligado à aldeia de Vilas Boas no interior de Portugal.

125 Cabe aqui destacar que, embora não tenha existido quase nenhuma interação observada do grupo imigrante com franceses, essas relações são comumente de indiferença ou convivência harmoniosa. Contudo, algumas tensões se revelam quando as diferenças se acirram. Laura citou algumas vezes situações de preconceito sofridas por suas filhas no colégio e, além disso, um conflito com um de seus vizinhos, que lhe disse torcer para que o governo francês mandasse os imigrantes todos de volta aos seus países. Eleva-se nesse momento um discurso de ressentimento da condição ocupada pelo grupo imigrante. O vizinho, segundo contou Laura, teria quebrado um dos vidros do carro da família, onde estava colado um adesivo que aludia a Portugal, e por esse motivo ele responde a um processo judicial movido por Laura. Em suas palavras, "há franceses que são racistas. Não podem aceitar o fato de que temos algo, de que ganhamos a vida. Fazemos o trabalho que eles recusam, erguemos a França e depois são invejosos”. 
dessas relações, ressaltando continuamente o fato de terem se originado ainda na infância. André, Bernardo e Pedro têm quase a mesma idade e compartilharam a infância na aldeia. Segundo eles, ainda "andaram juntos na escola". Esse aspecto do discurso revela ainda uma valorização das relações atravessadas por afetos e memórias vividas na infância, sobretudo em âmbito aldeão, anteriores à migração. Somam-se a essas memórias as experiências conjuntas da experiência emigratória.

Essa possibilidade manifesta de mútuas visitações fez pensar a respeito das preferências e estratégias de fixação e adaptação do grupo imigrante na França. Bernardo, por exemplo, declarou ter sido influenciado por André a comprar sua casa em Goussainville. De certo mudo a constituição de um grupo em determinada vizinhança se relaciona ao que tenho tratado aqui como "estrutura de acolhimento" ${ }^{126}$, o modo pelo qual o próprio fluxo migratório produz fixações e institui polos, nós em que se cruzam de modo intenso algumas trajetórias. Esses polos apontam para padrões de residência e fixação. Isso se relaciona às possibilidades de trabalho encontradas e, sobretudo, às intermediações que imigrantes fixados há mais tempo podem oferecer em termos de moradia, trabalho, etc.

O trabalho

Houve, ademais, alguns dias em que pude acompanhar Laura e André até seus locais de trabalho e, no caso de André, observar aquele espaço durante algum tempo. Saíamos bem cedo, de carro. André levou-nos até bem próximo do local de trabalho de Laura, na região de Saint Denis, e depois seguiu para seu trabalho, em Auberville. Durante todo o caminho só se ouviu um idioma, o português. Isso não apenas porque André e Laura falam apenas em português entre si, mas principalmente porque fomos ouvindo a rádio Alfa, como ela mesma se intitula, "a rádio portuguesa em França" ${ }^{127}$. No

126 Essa estrutura se produz aqui à semelhança do que ocorreu na Espanha nos anos 1970, tal como descreveu Damião. A esse respeito, ver capítulo dois da dissertação.

127 A rádio Alfa é o mais conhecido veículo de comunicação voltado principalmente para o público português imigrante em Paris. A programação é quase totalmente feita no idioma português e as músicas são as preferidas do público imigrante, entre elas os artistas mais populares de Portugal. Essa não foi a 
caminho entre o ponto em que deixamos Laura e o local em que trabalha André, ele apontou diversos Cafés ${ }^{128}$ onde disse que costuma almoçar com seus colegas de trabalho. Têm, em geral, nomes como "Café Trasmontano" ou mesmo "Café Boa Vista", o que, segundo André, indica o lugar em Portugal de onde vieram os portugueses donos dos comércios. A maioria desses estabelecimentos estava fechada, no entanto. Segundo André, os proprietários estavam de férias e grande parte já teria retornado a Portugal naquele período.

Estive com André em seu local de trabalho duas vezes, onde permaneci todo o período da manhã. Ele trabalha em um enorme galpão que compra, armazena, separa e recicla metais variados. Não era, no entanto, um lugar onde eu conseguisse me situar com facilidade. Toda a agitação do lugar deixava André desconcertado, muito atarefado e confuso entre falar português comigo e falar francês com o público e os funcionários com quem se relaciona. No entanto, com alguma dificuldade consegui fazê-lo não se incomodar com minha presença e passei a observar com maior naturalidade as interações no local.

Enquanto me apresentava aos seus colegas de trabalho, fez questão de ressaltar a origem migrante de cada um. Não havia nenhum francês no grupo de funcionários: um argelino, um turco e dois portugueses, afora André. Além dos funcionários presentes,

única vez que a rádio Alfa apareceu no trabalho de campo. Durante a pesquisa na aldeia, em um momento de interação com Inácio em um dos Cafés, ele contou com entusiasmo sobre a festa anual promovida pela rádio em julho. A festa é algo muito grande, geralmente realizada em um estádio esportivo, e as principais atrações vêm de Portugal. Em 2012 foram os cantores Quim Barreiros e Lucenzo, cantor pop de destaque internacional, que nasceu em Vilas Boas e é frequentemente lembrado pelos imigrantes. Lucenzo costuma ser citado pelos imigrantes de Vilas Boas não por seu nome artístico, mas por seu verdadeiro nome e suas relações de parentesco. Seu prestígio é reconhecido e nas raras ocasiões em que retorna à aldeia gera grande comoção coletiva.

128 Conforma apontado anteriormente (ver primeiro capítulo), os Cafés são locais de comércio de bebidas e comida, espaços de interação e sociabilidade. Durante a etapa de pesquisa na aldeia se revelaram importantes lócus de observação. Trato novamente dos Cafés no próximo capítulo, procurando discutir os tipos de interação que se passam com frequência nesses espaços, bem como o que é colocado em jogo nessas interações. 
havia ainda outros que não pude conhecer porque já estavam de férias ${ }^{129}$. O chantier estava se preparando para encerrar suas atividades por um período. No entanto, André assinalou que todos os demais funcionários não presentes eram também imigrantes. Todos exercem funções manuais práticas, as menos especializadas.

Ademais, quando pudemos, em um intervalo, interagir no escritório em que trabalha André, ele fez questão de destacar o poder econômico de seu patrão, que também é português. Havia no escritório uma publicação voltada para o empresariado português imigrante radicado na França. A publicação era bilíngue e tinha uma reportagem que destacava a expansão da empresa de reciclagem do patrão de André e Pedro (conforme assinalado anteriormente, ambos são funcionários da mesma empresa, porém não trabalham no mesmo local). Lembrei pouco depois que Dênis havia revelado que seu patrão também é português, mesmo caso de Ivan.

Próximo do meio-dia deixei André e comecei a caminhar de volta a Goussainville. Combinei de encontrar Laura na gare de Saint-Denis ${ }^{130}$ para que voltássemos juntos. Antes de entrarmos no transporte a caminho de sua casa, Laura quis caminhar por Paris. Ela, além de assinalar insistentemente a grande ansiedade que sentia pela viagem que faríamos a Portugal, expressou algumas impressões suas sobre aspectos da metrópole parisiense. Disse principalmente que:

são muitas construções velhas, todas iguais e muito cinzas. Não me agrada. Não sei porque isso atrai tanta gente de todo lugar do mundo. Prefiro a natureza, prefiro a paisagem do campo, mais colorida e mais viva.

Essa fala expressa de modo icônico certa recusa pelo espaço urbano, o que é significativo para pensarmos aspectos da subjetividade do imigrante de origem rural,

\footnotetext{
129 Interagi brevemente com os colegas de trabalho de André que são portugueses. O mais interessante desse breve diálogo foi o fato de terem me perguntado se eu tinha ido trabalhar na França. Por não ser francês e ter sido apresentado por André, deduziram que eu fosse também imigrante.

130 Gare é o termo francês, utilizado por Laura, para se referir às estações de acesso ao transporte público. Saint-Denis é o nome da estação que utilizamos como referência para nos encontrarmos.
} 
inserido na cidade principalmente a partir de suas margens. Fomos ao bairro de Montmartre e caminhamos por entre ruas de comércio popular, repletas de artigos para turistas. Ela desejava comprar algumas coisas para a viagem. Comprou roupas para suas filhas e, além disso, comprou alguns pequenos presentes para amigos na aldeia. Tudo isso se passou muito rapidamente. Por fim, caminhamos de volta à estação e nos encaminhamos para Goussainville, onde ela se apressou em adiantar os preparativos para o aguardado retorno a Portugal ${ }^{131}$.

\section{Alguns círculos portugueses na França}

Nesse trecho da pesquisa procuro pensar outros espaços observados e frequentados nos quais os migrantes também estabelecem formas de interação significativas. São círculos de interação para práticas definidas. Quando me refiro a "círculos" portugueses, penso nos espaços de reunião e convivência entre imigrantes que transcendem a esfera doméstica e do trabalho. Trata-se de espaços comuns de convergência com diversas finalidades práticas (consumo, lazer, dança, etc.).

Às vésperas de partirmos, acompanhei ainda Laura até um pequeno mercado local chamado "Casa Portuguesa", em Goussainville. Ela desejava comprar alguns itens para levar na longa viagem até Portugal. Esse estabelecimento, no entanto, caracterizase por comercializar produtos voltados para o contingente português imigrante. São principalmente alimentos e bebidas produzidos em Portugal, tais como embutidos, queijos e cervejas das marcas mais populares.

Além desses itens, são negociadas variedades como adesivos (costumeiramente utilizados nos carros) com as cores da bandeira nacional portuguesa, a própria bandeira em tecido, canecas e chaveiros que, além das características cores vermelha e verde, trazem por vezes mascotes, cores e escudos das equipes de futebol mais populares de

\footnotetext{
131 Formas de reconstrução de práticas que remetem a aspectos da subjetividade relacionados ao passado de origem rural se revelam em nuances da vida cotidiana, a exemplo do cultivo da horta, da participação em grupos de dança folclórica, na alimentação e por vezes na predileção musical. Sobre o processo de inserção do migrante de origem rural em contextos urbanos em seus nuances e aspectos fundamentais, consultar o trabalho de Eunice Durham (1978).
} 
Portugal. Esse e outros espaços ${ }^{132}$ caracterizam um consumo de certo modo "identitário", sem intuitos imediatamente utilitaristas, mas que contribuem entre os imigrantes para certa produção de subjetividades ${ }^{133}$.

No entanto, os círculos públicos de convivência de imigrantes não se resumem aos espaços de consumo. Há também em Goussainville uma espécie de "casa de cultura portuguesa", uma associação que concentra a participação de parte dos imigrantes. Trata-se da Association Portugaise de Goussainville (APG) ${ }^{134}$. Aqui me refiro a esse espaço com brevidade porque não pude realizar nenhuma observação ou mesmo travar qualquer interação em seu âmbito, pois tinha encerrado suas atividades para as férias ${ }^{135}$. O espaço da associação portuguesa, no entanto, aparece como de importância destacável, pois foi frequentemente referido.

Conforme detalhou Laura, trata-se de um espaço de "práticas culturais". Ao produzirem alguma representação do que é "tradicional" e "folclórico", se empenham em realizar atividades que auxiliem na "defesa" dessas práticas. Promovem contextos de reunião deliberada e sociabilidade como festas, jantares e recreação (principalmente jogos de carteado), mas sobretudo se esforçam na formação e preparação de um "rancho folclórico", grupo de música e dança folclórica portuguesa, que se apresenta em diversas ocasiões em outras associações de imigrantes portugueses pela França. Cabe destacar, como último aspecto, que Laura, suas filhas e Dênis participam do rancho da asso-

132 Cabe lembrar as feiras de rua que ocorrem no quartier de André e Laura às quintas-feiras, marcadas pela grande presença de imigrantes, inclusive portugueses. Grande parte dos itens comercializados é também voltada para os imigrantes: camisetas com estampas relacionadas a Portugal, doces e outros alimentos procurados constantemente pelos imigrantes.

133 A manifestação identitária tem no contexto francês observado um aspecto fundamentalmente relacional e situacional. A identificação é fortemente marcada por traços distintivos relacionados aos símbolos nacionais portugueses, como forma de dar visibilidade coletiva aos imigrantes. Contudo, também é capaz de expressar uma dimensão subjetiva, como ato simbólico. Sobre o tema, podem ser consultados os trabalhos de Gell, 2008: 149; Appadurai, 2008; Douglas e Isherwood, 2009.

134 “Associação Portuguesa de Goussainville”, que define institucionalmente sua função como "defesa e desenvolvimento do folclore tradicional de Portugal".

135 No intervalo dos dias que permaneci como hóspede na casa de André as associações haviam encerrado suas atividades. Estavam fechadas para o período de férias dos imigrantes e só voltariam a ter alguma programação quando a maior parte estivesse novamente na França, no final de suas viagens de retorno a Portugal. 
ciação de Goussainville. Laura inclusive mostrou, orgulhosa, as vestes que ela e suas filhas utilizam para dançar, tendo explicado apontando em fotografias alguns aspectos da dança e dos trajes. Sua filha mais velha, ademais, também aprende a tocar acordeão nessa mesma associação ${ }^{136}$.

\section{- 3.3 "E VÓS, QUANDO É QUE VÃO PARA BAIXO?" ${ }^{137}$ : A VIAGEM DE RETORNO}

Aproxima-se o momento de partir para Portugal e a ansiedade atinge seu nível máximo. Laura chegou a dizer que a semana parecia não acabar nunca. No trabalho, André apressou o preparo dos últimos detalhes com a expectativa de evitar ter que trabalhar no sábado. Sua expectativa era para que pudéssemos partir no meio da madrugada, nas primeiras horas da segunda-feira.

Esse é o momento final em que se explicitam, uma última vez, as relações de colaboração e proximidade do grupo imigrante de Goussainville. Isso porque combinaram de seguir "para baixo" em caravana. Por diferentes motivos, nem todos puderam, mas André, o senhor Joaquim e Pedro percorreram conjuntamente o caminho. A viagem em grupo é, entretanto, bastante complicada: uns esperam pelos outros e assim se realizam muitas pausas ao longo do percurso de mais de mil e quinhentos quilômetros até Vilas Boas.

Além disso, o percurso foi em grande parte retardado por um extenso congestionamento. André comentou isso ser bastante comum nas estradas naquele período, devi-

\footnotetext{
136 O que tenho a assinalar sobre a associação de Goussainville não é mais do que o envolvimento que a família de Laura e André indicou ter com esse espaço. Para além disso, apresenta-se como lugar potencial a partir do qual podem se estabelecer novas observações e interações de pesquisa que podem expandir a percepção da imigração portuguesa na França. Sobre as associações de imigrantes portugueses tomadas a partir da participação da chamada "segunda geração", ou seja, dos filhos de imigrantes nascidos no contexto de destino, ver o trabalho de Irene dos Santos (2010).

137 "Ir para baixo" é uma expressão nativa utilizada para se referir à viagem de retorno a Portugal, bem como "tornar para cima" é a expressão equivalente, utilizada para se referirem à viagem de volta à França. Elas apareceram em algumas ocasiões de interação entre imigrantes portugueses.
} 
do às férias. Devido a esse congestionamento, a viagem demorou por volta de vinte e três horas. Carla e sua filha recém-nascida nos acompanharam. Ela havia sido convidada para conhecer a aldeia. A esse respeito percebo que algumas das relações de parentesco não-consanguíneo construídas nos contextos de destino se estendem pelo campo social transnacional, inclusive até a aldeia natal, foco das trajetórias migrantes ${ }^{138}$.

Chegamos a Vilas Boas à noite. Quando próximos ao conjunto de montes e morros vizinhos à aldeia, André e Laura visualizaram muito antes de mim o santuário de Nossa Senhora da Assunção, no topo da montanha que margeia o vilarejo. Estava bastante iluminado e se destacava no breu do ermo montanhoso. Ali se anunciava já o tempo festivo da aldeia, com aquelas luzes que de tão longe davam boas-vindas aos que retornavam depois de um longo ano de afastamento.

138 De mesmo modo, no ano anterior foi Dênis quem acompanhou André e Laura até Portugal. De qualquer modo, Dênis sempre vai até Vilas Boas nos principais dias da festa e da procissão da aldeia. No restante do tempo de suas férias fica com seus pais, na aldeia em que cresceu, também no nordeste português. 


\section{PARTE 2}

\section{RETORNO E FESTA}


“(...) há um devaneio do homem que anda, um devaneio do caminho. (...) Como permanecem precisas na consciência muscular as veredas familiares da colina!” (BACHELARD, 1996 [1957]: 30)

"(...) a festa não é mais que uma tentativa de fusão da vida humana, de negação geral do indivíduo, como tal, uma aspiração à destruição das existências separadas" (SANCHIS, 1983: 34)

"Ó sino da minha aldeia, Dolente na tarde calma, Cada tua badalada Soa dentro da minha alma.

E é tão lento o teu soar, Tão como triste da vida, Que já a primeira pancada

Tem o som de repetida.

Por mais que me tanjas perto Quando passo, sempre errante, És para mim como um sonho, Soas-me na alma distante.

A cada pancada tua, Vibrante no céu aberto, Sinto mais longe o passado, Sinto a saudade mais perto."

(Fernando Pessoa) 


\title{
CAPÍTULO 4
}

\section{PENSANDO O TEMPO CÍclico DA FESTA: OS SIG- NIFICADOS DO RETORNO E DA COMEMORAÇÃO}

\author{
- 4.1 "MEU PORTUGAl É A ALDEIA" ${ }^{139}$ : AS VIAGENS DE RETORNO E \\ OS ESPAÇOS E ELEMENTOS DA FESTA
}

Em Vilas Boas as festas em celebração às crenças locais começam no final de julho e são acompanhadas pela chegada dos primeiros emigrantes. A repetição circular do evento divide o ano entre a abertura festiva que o verão representa e o progressivo fechamento que o outono anuncia com o fim das colheitas e o arrefecimento do calor exorbitante ${ }^{140}$. As muitas festas do concelho tornam-se espaços de sociabilidade ${ }^{141}$,

\footnotetext{
139 Frase dita por André durante a viagem de retorno da França a Portugal, repetida de forma semelhante por diversos outros agentes em campo.

140 Joaquim Pais de Brito descreve essa mesma lógica cíclica de fechamento e abertura a partir da oposição entre inverno e verão, descrevendo a estação fria como aquela das incertezas com relação à colheita e da centripetia das comunidades, frente à "abertura da comunidade ao seu exterior, ativação de uma sociabilidade inter-aldeã bem patente nas mútuas freqüentações das festas dos santos padroeiros e
} 
dentre os quais a festa de Nossa Senhora da Assunção é o apogeu, exemplo quase idealtípico das romarias de verão portuguesas. Há também uma quantidade destacável de emigrantes que retorna à aldeia somente para os dias do festejo. A partir do dia dez de agosto a quantidade de carros cresce quase que instantaneamente nas portas das casas e nos canelhos ${ }^{142}$ próximos aos Cafés. É bastante sugestivo e significativo perceber o crescimento da quantidade de carros e a diversidade de origens registradas nas suas matrículas.

Neste último capítulo procuro produzir uma reflexão sobre a festa e tudo quanto é colocado em jogo no contexto festivo. Doravante, os colaboradores que intermediarão minha entrada no campo se multiplicarão e as relações encetadas serão atravessadas por marcações relacionadas à festa e suas datas de referência.

A escolha de um contexto de pesquisa

O contexto festivo é o momento escolhido para a realização de boa parte uma pesquisa que procura registrar como se dão os ajustes das categorias e relações locais, bem como quais são os aspectos que funcionam regularmente como laços que sustentam a ligação dos migrantes com a sociedade de origem.

A proposta de uma etnografia do período festivo apresenta potencialidades que merecem ser exploradas a fundo. É preciso a esse respeito dizer que o aguardado verão é o período do ano para o qual a maioria dos emigrantes agenda suas férias, quer durem

nas deslocações e encontros no espaço comum do santuário e das romarias" (1996: 217) e à fartura das colheitas de verão.

141 A noção de sociabilidade tem aqui força de conceito. Segundo a tradição ancorada em Georg Simmel, a sociabilidade é uma forma específica de encontro, em que a sociação é definida pela autonomização dos conteúdos e finalidades da interação, que se executa enquanto forma, tão somente pela satisfação que a interação provê, quando a interação é constitutiva do social e erige como um valor relacional, um impulso dinâmico de reciprocidades interativas e interesses compartilhados (cf. Simmel, 2006 e Frúgoli Jr., 2007).

142 "Canelho" é um termo nativo relativo a "calha", rua estreita, o equivalente a viela. 
um mês todo ou apenas alguns dias ${ }^{143}$. As aldeias e freguesias em geral concentram nesse período a comemoração de festividades de caráter religioso, em homenagem aos santos padroeiros de cada uma delas, enfeitam-se e produzem ciclicamente uma temporalidade festiva extremamente ansiada, sobretudo por aqueles que passam o ano afastados por conta da emigração. Esses festivais anuais são o principal referente para a renovação de um ciclo de afastamento e retorno, ou seja, pontuam a renovação contínua da dinâmica emigratória das aldeias do norte português.

A etnografia da festa revela-se, ademais, um instrumento privilegiado de observação, uma estratégia ${ }^{144}$ que se vale do caráter cíclico da dinâmica emigratória para realizar a observação de uma situação de aglutinação de eventos, de grande intensidade de práticas e interações. A aldeia vive dias de frenesi incomparável a qualquer outro momento do ano. É nesse momento que ocorre um número significativo de reencontros e a possibilidade de conviver se realiza. A partilha da vida se efetiva pela e na festa. É também no contexto da festa que os conjuntos de relações se atualizam e reestruturam; é igualmente nesse contexto que é colocada em movimento toda a simbologia caríssima aos processos locais de significação. A observação e a interação tornam-se peculiarmente densas nesse contexto. De maneira mais pragmática é, em termos de estratégia de pesquisa, o momento em que as trajetórias podem se entrecruzar de maneira surpreendente ou, dito de outra forma, diversos vetores convergem e se cruzam produzindo o contexto.

143 Emigração e retorno, cotidiano e festa, trabalho e férias são oposições que orientam a temporalidade vivida pela parte dos emigrantes que participa da dinâmica de afastamento e retorno em Vilas Boas. João Leal expõe situação semelhante para as festas açorianas conhecidas como 'Impérios': “Com as transformações inseridas na calendarização tradicional (...) os 'Impérios' tendem agora a funcionar, no quadro dos novos constrangimentos impostos ao ciclo anual pela emigração, como um mecanismo ritual de reconstituição da unidade de uma 'comunidade' dividida pela emigração" (1996:587). Sobre a relação entre calendário festivo e condicionantes da dinâmica migratória, ver também Sanchis (1983).

144 A festa, embora não seja um ritual no sentido estrito do termo (já que comporta uma dimensão imprevista de acontecimentos não prescritos), em sua dimensão cerimonial assegura que possamos destacá-la como um "tipo especial de evento, mais formalizado e estereotipado e, portanto, mais suscetível à análise porque já recortado em termos nativos" (PEIRANO, 2001: 8). Trata-se, segundo Peirano, de uma forma de tomar os "rituais como estratégia analítica", ou ainda, conforme Lea Perez, da "festa como perspectiva" (2012). 
Nesse sentido, a festa pode ser considerada um momento peculiar do ciclo ritual da aldeia. Ela demarca os intervalos da vida social. Todo o planejamento dos demais períodos é pensado com referência à festa. Tal como afirma Edmund Leach, "entre as várias funções que a celebração de festivais pode preencher, uma função muito importante é a da ordenação do tempo. (...) Nós criamos o tempo através da criação de intervalos na vida social" (2006: 207). Tomada a partir de sua temporalidade instituída, a festa apresenta as características que Maria Laura Cavalcanti descreve ${ }^{145}$ :

\begin{abstract}
"Os rituais trazem consigo uma temporalidade quente, i.e., um período em que a experiência social torna-se particularmente intensa e ganha colorido característico - são aqueles dias ou é aquela semana vividos de modo especial, que requerem muitos encontros e nos quais muitas coisas acontecem ao mesmo tempo" (CAVALCANTI, 2011: 4).
\end{abstract}

A fé na santa da aldeia apresenta-se, assim, como mais um princípio pelo qual se constitui de modo complexo o mote para o retorno: a volta durante o período festivo é também motivada pela religião, pela romaria e, muito comumente, por alguma promessa que precisa ser cumprida naquele lugar (sagrado) e naquele momento (excepcional). Festa e emigração imbricam-se, portanto. Aqui é possível falar, como faz João Leal ao pensar as relações entre a celebração açoriana dos "Impérios" e a emigração, em uma "nova ordem ritual", "marcada pelo peso crescente dos emigrantes na [sua] realização" (1996: 585). As celebrações religiosas locais em Vilas Boas também são parte de um único processo de transformações relacionadas que a emigração conjugou.

145 Como assinala Maria Laura Cavalcanti: "os rituais são dotados de extrema concretude, de extrema materialidade. (...) Eles não só se desenrolam necessariamente em um fluxo temporal - que tem começo, meio e fim - como exigem um lugar no espaço e uma espécie de intervalo no fluxo temporal mais rotineiro. Precisam encontrar abrigo num certo momento de um calendário mais amplo de uma dada sociedade, de um grupo social. Precisam do acordo e da ação concertada de muitas pessoas para acontecerem. (...) A passagem do tempo, assim pontuada pelos rituais, ganha um ritmo coletivo característico, que diminui morosamente ou se acelera candente, trazendo consigo a experiência coletiva de emoções e sentimentos expressos de modo padronizado" (2011: 3-4). 


\section{O fundo mítico e a historicidade local}

Após ter tratado de aspectos gerais das festas populares portuguesas, buscarei uma circunscrição mais exata da festa, principiando por um enquadramento do fundo mítico que a baseia. Desse modo, farei uma descrição breve dos motivos estruturais da festa e de sua simbologia, procurando demonstrar como essa simbologia se enreda no espaço doméstico dos agentes e envolve a aldeia. Entram nesse cômputo histórias e figuras de santos, histórias profanas e uma reflexão sobre a sistematicidade cíclica do tempo festivo.

Importa começar dizendo que as festas veraneias do interior de Portugal são, em sua maioria, homenagens das aldeias aos seus respectivos santos padroeiros (um esquema tomtêmico de símbolos e representações). As relações de cada pequena aldeia com a santidade a ela associada são de tal modo complexas e próprias que se revelam estruturantes da compreensão possível do modo que os agentes motivam suas práticas e produzem significado. Além disso, embora o fenômeno do retorno anual e temporário dos emigrantes portugueses para o período festivo seja algo tão constante e notório que até se converta em objeto de análise estatística, em Vilas Boas assume um aspecto de tal modo específico, entrecortado por elementos da história local, que é relevante elencálos para discussão.

O mais relevante deles é relativo aos motivos da festa anual da aldeia: diferentemente da maioria das festividades de cunho religioso celebradas durante o verão português, não se trata de homenagear um dentre os muitos santos da imensa plêiade católica, mas de reencenar uma parte da história local, já que as histórias de milagre de Nossa Senhora da Assunção, padroeira da aldeia, descrevem suas aparições no território da própria aldeia e de seus arrabaldes. Toda adoração e reverência à imagem e à santa concentram esse aspecto, tal como argumenta Pierre Sanchis:

“esta presença do santo é a emblemática da comunidade da qual recapitula a história e concentra as energias. Se esta presença é tutelar e, em todos os momentos, garante de continuidade, de vida e de abundância, é precisamente porque (...) permite a presença reflexa do grupo a si próprio, a intensificação de uma autoconsciência, uma adesão 
às raízes sociais, uma certeza de identidade. Perdendo-a, a comunidade teria consciência de renunciar ao seu próprio ser, para se reduzir ao anonimato e se fundir num todo social englobante que já, de certa forma, a domina" (SANCHIS, 1983: 43)

No caso de Vilas Boas, a festa gira ao redor de um santuário situado no cimo de um outeiro nas margens da aldeia ${ }^{146}$. A elevação montanhosa que abriga o templo compõe em agosto o calendário das peregrinações católicas marianas. A festa constitui uma espécie de arraial composto de uma alternância ritualizada entre o cronograma religioso de missa, oração e procissão (a romaria ${ }^{147}$ propriamente dita), e as atividades de lazer profano entremeadas. Pierre Mahe descreve este aspecto dizendo que "a festa comporta sempre dois elementos, de romaria e de folia, ou seja, aspectos religiosos de peregrinação e aspectos de divertimento" (1998: 251, tradução minha). Ainda segundo Sanchis, "a sua característica essencial é a de serem organizadas em torno da 'memória de um santo' representado por uma relíquia ou uma imagem”. A romaria é uma peregrinação popular a um lugar tornado sagrado pela presença especial de um "santo" (SANCHIS, 1983: 39).

No entanto, para Vilas Boas, mais do que celebrar o dogma da assunção na data estipulada pela Igreja Católica, trata-se de encenar uma parte da história local ou, como afirma Geertz (1989: 316), dramatizar e recontar uma história sobre e para si próprios. Desse modo, quando a assunção de Nossa Senhora é celebrada, não é apenas com referência aos significados que esse evento possui no calendário da Igreja, mas principalmente como forma de reencenar a história local através da narração dos milagres e asgeral, "a romaria tem por sede um santuário 'no campo', mais frequentemente na orla de uma aldeia, por vezes a vários quilómetros de distância ou mesmo num sítio isolado de qualquer aglomeração" (1983: $40)$.

147 A definição fornecida por Ernesto Veiga de Oliveira abarca todas essas dimensões: “As romarias são fundamentalmente celebrações religiosas em honra de qualquer santo ou invocação divina, patronos de uma localidade ou de um santuário, compreendendo missa de festa com sermão e prática, e, as mais das vezes, procissão (...), que tem lugar no seu dia e nesse santuário, duplicadas de uma festa profana característica, em que coexistem elementos de todas as espécies, religiosos e profanos, cristãos e mágicos, cerimoniais e festivos, num caleidoscópio extremamente variado e complexo" (1995: 217). 
sunção de Nossa Senhora ocorridos no território da aldeia. Também por isso a festa constitui um evento envolvente ancorada em uma mitologia que se perpetua pelo interesse reiterado dos emigrantes e aldeões na produção do cortejo processional e da festa. À volta dessa crença comum estão envolvidos diversos tipos de investimento: como aspecto que converge interesses e mobiliza (no sentido de que motiva a ação, coloca em movimento, propulsiona), a festa centra atenções por sua relevância como espaço de negociação simbólica em que a religio promete aqui mais uma vez religar o homem, não apenas ao sagrado, mas sobretudo à comunidade de culto. O interesse manifesto é uma espécie de negociação sempre aberta pelo pertencimento, pela definição do grupo e de suas fronteiras, e que demanda uma atualização contínua e repetida das posições sociais em jogo, da inserção diferenciada de cada um na realização coletiva da festa ${ }^{148}$.

Como grande parte das aparições marianas ${ }^{149}$, a narrativa oficial descreve que em suas aparições e milagres, Nossa Senhora da Assunção teria aparecido por três vezes a uma menina chamada Maria. As aparições teriam ocorrido em finais do século XVII, mais exatamente em 1673, e são hoje enquadradas pela Igreja Católica segundo as definições do "dogma da assunção" ${ }^{150}$. Embora sejam atualmente celebradas em agosto as festas da assunção, as aparições teriam ocorrido em setembro em três diferentes pontos da aldeia, tais que: a fonte d'água do Ribeiral ${ }^{151}$ (considerada sagrada e milagreira, pon-

148 Existe uma forma de abordar a festa como objeto de observação etnográfica que tem como princípio traçar as semelhanças e diferenças que são produzidos no contexto festivo. Nas palavras de Norberto Guarinello, "o que chamamos de festa é parte de um jogo, é um espaço aberto no viver social para a reiteração, produção e negociação das identidades sociais. Um lapso aberto no espaço e no tempo sociais, pelo qual circulam bens materiais, influência, poder. $\mathrm{O}$ que chamamos de festa é um espaço significativo por excelência, um tempo de exaltação dos sentidos sociais, regido por regras que regulam as disputas simbólicas em seu interior e que podem, por vezes, ser bastante agudas. A festa unifica, mas também diferencia, tanto interna quanto externamente. Uma distinção primeira, e fundamental, é a entre incluídos e excluídos da festa. Festas podem ser mais ou menos abertas, mas sempre traçam fronteiras, espontâneas ou impostas, entre os aptos a dela participar e os que são estranhos a ela” (2001: 973).

Sobre as características comuns das aparições marianas, ver Sales, 2008.

150 Para consultar a versão oficial do milagre, fiz uso inicialmente do texto disponível no site do santuário, disponível em http://santuario-assuncao.pt/santuario.htm (consultado pela última vez em 05/09/2013). Sobre o “dogma da assunção”, consultar nota dezesseis.

151 Sobre o caráter sagrado de elementos naturais da paisagem aldeã, Sanchis nota certa regularidade nos diferentes casos, sempre relacionados às histórias populares acerca do santo: "Por vezes, 
to de passagem dos romeiros e fiéis), a "eira Monteira" (local em meio à floresta de eucaliptos por onde durante muito tempo se fez a procissão, demarcado com um cruzeiro, referente para as procissões que antecedem a grande festa do dia quinze de agosto) e o Cruzeirinho (lugar em que uma cruz pontua uma encruzilhada nas margens da aldeia).

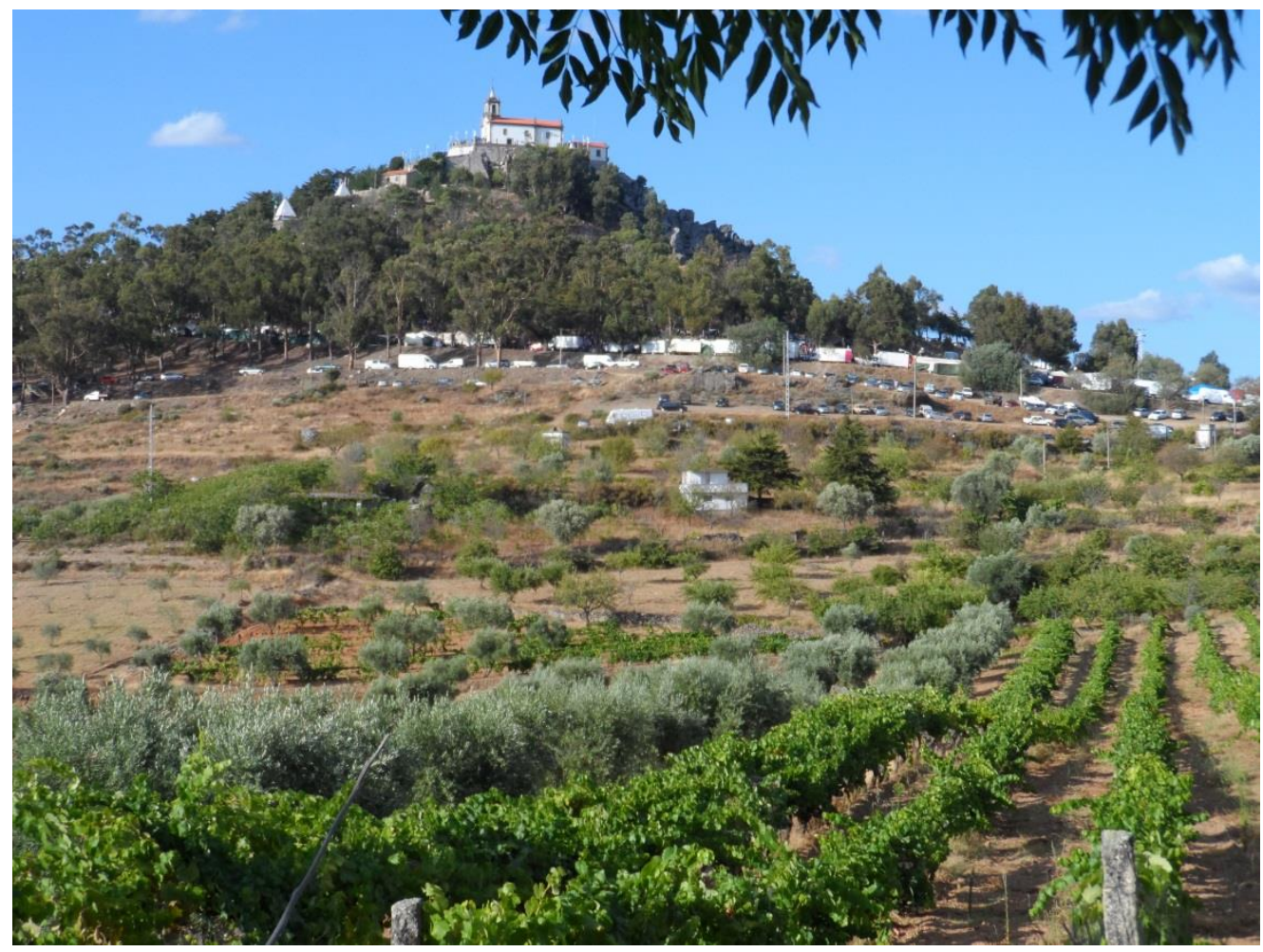

Figura 5. Santuário de Nossa Senhora da Assunção visto da aldeia, com o monte repleto de veículos que assinalam a ocupação excepcional desse espaço nos dias festivos.

Desse modo, o trabalho a seguir busca entrever de que modo essa história fornece o fundo de uma celebração que envolve a participação de agentes que estão em contínuo trânsito transnacional, mas que de alguma forma se ligam às fronteiras que são produzidas na vivência dessa festa. A produção da festa é tomada no conjunto das relações e práticas de emigrantes e residentes. O quadro social de retorno massivo dos emigrantes pode ser melhor perspectivado em sua dimensão relacional, não somente no

um outro elemento da natureza reveste-se de um significado religioso característico: água (banhos sagrados, fontes milagrosas), árvores ou plantas (...), rochedos. Mas (...) sempre relacionado com o objeto principal de devoção, o depositário e representante histórico do sagrado: o 'santo"” (SANCHIS, 1983: 41). 
âmbito da produção transnacional de relações, mas também da conexão produzida pela dimensão afetiva que envolve a prática da religiosidade local.

- 4.2 “E ESTE ANO, VENS À FESTA?”: ESPAÇOS DE SOCIABILIDADE COMO LUGARES DE PROXIMIDADES COMPLEXAS E DISTANCIAMENTOS TENSOS

Depois de ter retomado anteriormente algo do fundo mítico que subjaz à simbologia da festa e aos seus motivos mais fundamentais, procuro pensar a vivência da festa em seus dias, sua ocorrência vivida e atual. Nesse momento descrevo as dinâmicas que pude observar em diversos contextos envoltos pela ambiência festiva. Aqui contemplo uma dimensão mais espacial da observação, que busca integrar, em sua perspectiva, práticas e lugares. Abro caminho, portanto, para um trabalho mais propriamente etnográfico de descrição de situações complexas e específicas, em lugares que compõem centralidades importantes para a interação social e a sociabilidade no contexto que conjuga o retorno dos emigrantes e a celebração festiva (do verão, das férias, das santidades locais e do pertencimento familiar).

Procuro aqui explorar os elementos potenciais de uma etnografia da festa, articulada à observação de diversos outros aspectos dos espaços de sociabilidade e das relações constitutivas da vida social na aldeia. $\mathrm{O}$ aspecto oficial e ritualesco da festa abre aqui espaço para uma análise da sociabilidade e da dimensão profana. Além do caráter eminente e vistoso dos eventos religiosos, perseguidos e vividos nesse contexto, é importante ainda ter em conta outra dimensão simultânea da vida social - que não é meramente complementar -, relacionada à apreciação mundana desse tempo, à produção de uma temporalidade excepcional, de gozo e celebração, de comemoração ${ }^{152}$.

No começo daquele mês de agosto, em 2011, conheci João, marido de Lúcia. João vive já há mais de uma década em Vilas Boas, desde que se casou. Ele é, na verdade, original de Cachão, aldeia das proximidades. Lúcia tem cerca de trinta e quatro

\footnotetext{
152 Destaca-se o aspecto sociativo desse tempo, marcado pela intensidade das interações. A própria ideia de comemoração, por sua etimologia que provem do latim "commemorare", expressa a ideia de "trazer à memória" conjuntamente.
} 
anos e é a irmã mais jovem do meu pai, tia que eu nunca havia conhecido. Lúcia trabalha no hospital de Vila Flor - sede do concelho e vila urbana - como auxiliar de enfermagem. João tem trinta e seis anos e trabalha como motorista na empresa regional de coleta do lixo ${ }^{153}$.

Desde que cheguei pela primeira vez na aldeia, João assumiu um papel importante de mediação e colaboração na pesquisa. Por seu intermédio passei a circular e estar situado (no sentido de ter um lugar compreendido, de ser, enfim, aceito) em diversos ambientes, sobretudo no "Café do Tavares" ${ }^{154}$. Graças a essa via de acesso propiciada pela mediação de João, pude passar a frequentar vários ambientes de sociabilidade da aldeia. Foi por seu intermédio que cheguei a conhecer André, Zeca, o próprio Tavares e os irmãos Inácio e Aloísio.

Quando passei a acompanhar João, o tempo festivo apresentou sua dimensão lúdica. Passei a observar que a festa em Vilas Boas institui, destarte, mais do que um espaço de sociação, uma temporalidade da interação. Não só no espaço do bailarico, no curto intervalo de horas em que se executa música na fruição festiva após a procissão, mas durante todos os dias que antecedem o ansiado dia quinze.

Tendo essa dimensão em conta, nota-se Pierre Sanchis chama de volta a atenção para os diversos aspectos sociais da atividade religiosa:

"O essencial é que toda a romaria constitui um ajuntamento, um encontro e um momento de vida em comum: quer troca recorrente de visitas, quer multiconvergência, expressão de uma unidade regional, quer junto à fronteira, de norte a sul, abolição de barreiras políticas e símbolo fugaz da fraternização. Estes 'reencontros' (...) são ocasião de toda a espécie de trocas culturais, comerciais, agonísticas" (SANCHIS, 1983: 40)

153 Embora atualmente ambos se empreguem no mercado de trabalho urbano mais próximo, trabalharam (e esporadicamente empregam-se em trabalhos temporários) em atividades rurais de plantio, poda, colheita, etc. João inclusive chegou a trabalhar na Espanha em contratas de colheita.

154 No Café de cima, entretanto, meu acesso foi criado pela mediação de Josefa e Damião. Como assinalo adiante, uma parte dos conflitos se revela para a observação ao notar aqueles que evitam um ou outro espaço. 
A seguir procuro produzir a análise etnográfica a partir de contextos de sociabilidade, organizados em tópicos para descrições detidas de situações específicas de interação e observação do trabalho de campo.

No café: territorialidades, espacialidades, sociabilidade, conflitos e tensões

Neste ponto desejo expor algumas situações que condensam tensões fundamentais presenciadas. Considerando esse ambiente social que o retorno ocasiona, alguns espaços convertem-se em pontos fulcrais da observação e da interação de pesquisa.

A observação dos espaços de sociabilidade durante esse período suscita por isso a possibilidade de desvelar proximidades e distâncias reveladoras de estratégias sociais (que envolvem status, parentesco, etc.) que se inserem nas trajetórias migrantes. Sentar à mesa em algum café é, por isso, uma das principais maneiras de encetar uma interação mais densa, é estar exposto a situações em que o imprevisto das interações adquire potencial para a observação etnográfica ${ }^{155}$.

Há em Vilas Boas três Cafés: o Café Trasmontano (chamado corriqueiramente de "café de cima", por ser aquele que fica no ponto mais alto em relação aos demais no que se refere à topografia da aldeia), o Café do Teixeira (incrustado no miolo da aldeia, preferido da maioria) e o Café de baixo (situado no "Lameiro", parte mais baixa na topografia da aldeia, com sérios problemas financeiros, e que estava por isso prestes a fechar, encerrar suas atividades).

Espaço aberto da fala, da sociabilidade, das interações jocosas, do flerte e de outras várias formas de lazer, nos Cafés entrevê-se grande quantidade de interações discretas (pagar a outrem uma bebida, interagir ou evitar alguém, etc.), formas sutis de assinalar o status, afinidades e tensões. Ao pensar o espaço do Café em sua pesquisa sobre a aldeia de Pardais, Miguel Vale de Almeida afirma que "usar ostensivamente o dinheiro é mostrar uma agência autónoma plena" (2000: 178). Segundo o autor, o dinheiro "é

155 Além disso, é importante dizer que os Cafés foram também espaços de construção de relações, de ampliação da rede para a pesquisa. A partir de relações que principiaram em diálogos no Café, encetei contato com diversos emigrantes que estão em sua maioria na França. 
usado como símbolo e figura de retórica" e por isso é importante que seja "mostrado e circulado em contextos colectivos de convidar e pagar a outros" (Idem). Segundo o que pude observar, o Café é também um espaço de produção de distinções sociais situacionais, de circulação também de um capital simbólico pautado pela experiência migratória, de modo que essa simbologia associada ao dinheiro remete à ligação que o sujeito tem com o que Miguel Vale de Almeida chama de "cultura-mundo" (2000: 178).

Como característica da observação no espaço dos Cafés, é preciso ter em conta que são espaços de grande circulação e, em geral, lugares de passagem. Desse modo, embora fosse possível encetar interações nesse espaço, elas só se tornariam significativas conforme a tarefa de observação se repetisse em tais espaços.

As interações eram, de modo geral, mais rápidas e descontínuas, o que ocasionou dificuldades analíticas que passei a enfrentar por meio de uma abordagem tão descontínua quanto as interações ali empreendidas. A abordagem situacional detém essa característica descontínua uma vez que, tal como a concebe Michel Agier, "não são os limites espaciais que definem a situação, mas os da interação" (2011: 73). As noção de situação ajuda a recortar contextos de interação descontinuada, marcados, no entanto, por certo grau de coerência interna por um lado, e pelo agenciamento estratégico de marcadores capazes de produzir distinções significativas. Ou seja, a análise situacional toma momentos da observação segundo as regras que o regulam de modo destacável, pelos valores internos e disputas colocadas em jogo. Assim, distingo as situações observadas e analisadas a seguir em duas fundamentais: de lazer e de conflito.

Situações de conflito ou sociabilidade agonística

No Café se desenrola, portanto, a prática mais fluida da interação, mas que não é desprovida de desníveis e tensões, de agências veiculadas nos diálogos e relações jocosas. Espaço público de interação coletiva, nele está posta a possibilidade de tornar ex- 
plícitas diferenças que esboçam certa hierarquia. A descrição de algumas situações é bastante densa a respeito dessas tensões fugazes ${ }^{156}$.

Um das tensões mais recorrentes observadas referem-se, como já dito, a relações entre emigrantes e residentes, a diferenças que se formam entre os que partem e os que ficam. Durante o tempo que passei no Café, pude observar dia após dia a frequentação do ambiente e os tipos de relações ali empreendidas, entre emigrantes e deles com residentes. A frequentação oscilava ao longo do dia, mas à noite era sempre intensa, repleta de grupos e conversas quase berradas porque o volume de ruído e a quantidade de vozes ao mesmo tempo assim exigiam.

Em um dos casos, estava na companhia de João no Café do Tavares. Ele havia acabado de chegar do trabalho e ainda estava vestido com o uniforme da empresa. É bastante comum que nesse período os emigrantes estejam gozando as férias, mas os aldeões residentes não, e dessa disparidade emerge parte dos conflitos. Provocado jocosamente por um conhecido seu, emigrante, que lhe perguntou se tinha "muito apego à farda", João se irritou e decidiu abandonar o local ${ }^{157}$. No caminho, comentou

Há treze anos que trabalho nessa empresa [de recolhimento do lixo e aterro sanitário] em que agora estou e nunca pude tirar férias no mês

\footnotetext{
156 A ideia de "situação" aqui recorrida remete originalmente às formulações de um conjunto significativo de autores da chamada "Escola de Manchester", teóricos que, em sua maioria, se dedicaram a observar contextos de crescente e então recente urbanização na África em processo de descolonização em meados do século XX, profundamente marcados pela presença de grupos imigrantes advindos de zonas rurais (GLUCKMAN, 2009; MITCHELL, 2009). Essa noção foi depois apropriada e atualizada por outros autores na antropologia. Para uma noção mais ampla da trajetória da noção de situação, ver o trabalho de Frúgoli Jr., 2007.

157 João contou-me que já havia sido convidado a emigrar algumas vezes, por diversas pessoas, principalmente instaladas na França. Justificou que nunca aceitou emigrar porque não consegue se afastar da aldeia por inúmeros motivos, sente-se muito ligado ao lugar, mas principalmente porque isso implicaria viver um período mais ou menos longo afastado de sua família, até que pudesse conquistar alguma estabilidade financeira, algo bastante incerto e que poderia nunca acontecer. Em suas palavras, “parece que não, mas a vida de emigrante é muito sofrida. Eu sei bem o que me contam e sei o quanto penam lá fora para poderem ter algo. Eu sou muito mais pela família. Não quero perder o crescimento das minha filhas, entendes?".
} 
de agosto. Há muito mais serviço nessa data, muito mais lixo. Estamos sempre a fazer trabalho adicional, saímos de casa mais cedo, voltamos mais tarde, e não nos pagam nada mais por isso. Afinal, nem me lembro que é festa. Queria eu vê-lo na França, de uniforme, a trabalhar como escravo para os franceses.

Esse tipo de conflito não tem maiores consequências ou desdobramentos para os agentes, mas é relevante para entrevermos o que pauta as provocações jocosas e desentendimentos, que valores estão em jogo e produzem diferenciações significativas, e de que forma esses pequenos conflitos são entrecortados pela dinâmica migratória. Essas distinções podem ser notadas também nas situações em que, por diversos motivos, os emigrantes se comunicam em francês. Seja porque há no grupo algum francês ou emigrante que não fale português, ou mesmo porque desejam não ser compreendidos pelos não-migrantes, essa prática cessa o diálogo com os aldeões e geralmente produz algum constrangimento ${ }^{158}$.

Ao acompanhar Damião em visita ao Café de cima pude observar situações similares, de pequenos tensionamentos nas relações. Nesta ocasião conheci Flávio, rapaz de aproximadamente vinte anos, filho de emigrantes, que nasceu e vive em Vila Nova de Gaia, mas que passa com frequência períodos na aldeia. Grande parte de seus familiares ainda vive na aldeia, são os proprietários do Café. Naquela ocasião ele manifestava grande irritação com alguns emigrantes. Isso porque ao longo dos dias do retorno do grupo migrante, uma parte dos que regressam se entretêm circulando com motos, carros e quadriciclos pela aldeia, muitas vezes em alta velocidade. A maioria se concentra em torno do Café do Tavares. A esse respeito Flávio comentou que

\footnotetext{
158 A questão do idioma falado reaparece em outros momentos da pesquisa, sobretudo quando se trata dos filhos de emigrantes nascidos nos contextos de destino. Inácio, por exemplo, disse que o fato de avós portugueses e netos franceses não se entenderem representa uma "imensa vergonha". Por isso disse que fez questão de ensinar o idioma português para seus filhos (embora eu tivesse percebido que em suas interações na aldeia os filhos de Inácio falassem quase exclusivamente francês). De modo semelhante, André afirmou que exige de suas filhas que falem português em casa e deixem o francês para os ambientes externos, sobretudo a escola.
} 
Eles bem sabem andar com as motos nos montes, mas gostam de estar a correr na aldeia porque no monte ninguém os vê. Precisam sempre mostrar a moto, claro!

Flávio conhece a maior parte dos rapazes emigrantes da sua mesma faixa etária. No entanto, apesar de não viver na aldeia, não se considera parte do grupo migrante. Seu ressentimento se dá, principalmente, pelo que ele identifica como formas de ostentação. Flávio disse ainda que estava concluindo um curso profissionalizante e que, por algum tempo iria procurar trabalho em Portugal mas, caso não encontrasse, não descartava a possibilidade de também emigrar:

Faço depois como esses "franceses" ${ }^{159}$, que compram carros só mesmo para agosto e põem-se a exibi-los.

Nota-se, pois, distinções sensíveis entre aqueles que emigram para grandes cidades portuguesas e aqueles que saem para outros países. Essas distinções não dependem exclusivamente do destino escolhido pelo emigrante, mas sim de uma ordem de fatores variados, entre os quais se destaca o sucesso conquistado no contexto de destino.

Não existe, entretanto, uma cisão definitiva e estanque entre emigrantes e residentes. As tensões entre os que partem e aqueles que permanecem são acionadas contextual e situacionalmente, como elementos capazes de produzir distinções estratégicas, ora tornados aparentes, ora tornados ocultos conforme o jogo de valores disposto no curso da interação. As posições e condições sociais de cada agente não podem ser tomadas de maneira fixa. Elas são definidas contingencialmente no curso das disputas simbólicas e da construção das trajetórias. Grande parte dos aldeões pode decidir se tornar emigrante e qualquer emigrante pode voltar a viver na aldeia pelos mais diversos

159 Denominar algum emigrante como "francês", "brasileiro" ou ainda outra nacionalidade qualquer, conforme o país para o qual se tenha destinado aquele a quem se refere o autor da fala, é um ato profundamente pejorativo, que visa desqualificar o sentimento de pertença do emigrante. Brettell (2003: 69) nota esse mesmo aspecto distintivo, e chega a afirmar que os "franceses" constituem uma nova classe na aldeia. 
motivos: seja porque conquistou seus objetivos e escolheu voltar após a aposentadoria, seja porque não obteve o sucesso esperado e volta resignado para reconstruir sua posição na aldeia. Parte dos aldeões cogita emigrar, assim como boa parte dos emigrantes almeja retornar definitivamente. É nesse aspecto que recordo a maneira como Brettell avalia essa dinâmica: "ao emigrar, migrantes portugueses estão procurando no exterior um meio de conquistar prestígio e mobilidade no interior de seu próprio sistema social" (2003:64, tradução minha).

Todo esse quadro encetado pelas diferenças engendradas entre emigrantes e residentes faz pensar no consumo praticado na e para a festa. Eles revelam aspectos de estímulo à emigração que a ostentação dos emigrantes assume para os residentes. Situações de conflito se revelam em aspectos do consumo, o que envolve distinção, desejo, afetos e rivalidade em torno da hierarquia social não evidente que permeia as relações que se cruzam a partir da aldeia. São, no final das contas, práticas de consumo articuladas a estratégias de visibilidade. Brettell explica da seguinte maneira esse mecanismo de distinção:

\footnotetext{
"os aldeões são o júri que mede o sucesso do emigrante no exterior. As várias atividades públicas da igreja tornam-se um importante mecanismo para declarar e afirmar esse sucesso, porque elas provêm o emigrante da oportunidade de mostrar abertamente sua riqueza. Assim, atrás dos motivos econômicos da emigração, existem motivos sociais. Não é uma questão de sobrevivência, mas de melhorar a vida, de mobilidade social" (2003:89, tradução minha).
}

A ostentação do emigrante esconde um discurso de incentivo à migração porque transforma a configuração das exigências do sistema local de prestígio. Todos se sentem de alguma forma pressionados pela possibilidade de emigrar e não por acaso muitos acabam realizando pelo menos migrações sazonais. A intensa frequentação dos Cafés deixa de ser mero deslocamento e, para fazer uso de uma metáfora, se converte em exposição, num ato interessado de ver e ser visto, de se fazer ver.

E em meio a essa procura por reconhecimento sobressaem discursos que explicitam quanto o sucesso pessoal serve de princípio de avaliação daqueles que permaneceram na aldeia. Emigrar é um ato disruptivo, uma aposta que o sujeito faz contra a aldeia 
e da qual, para ser bem recebido no momento de seu retorno, precisa sair vitorioso. Essa característica pontua parte das relações entre os que partem e os que permanecem, notada a partir das pequenas tensões que se instauram nos dias das festas de agosto. O que acontece é que as pretensões subjacentes aos projetos emigratórios estimulam a competição por posições sociais e isso ocasiona situações de breve conflito ou ressentimento.

É preciso dizer também que há outras espécies de conflitos, mais sérios e duradouros do que essa pequenas tensões sugestivas. Essa outra espécie de conflito não ocorre nos Cafés, mas podem ser percebida através desses ambientes, uma vez que existem diferenças sensíveis e constantes entre na frequentação de cada estabelecimento. Ou seja, é importante dizer que cada Café tem seu grupo de clientes.

Embora haja inúmeros exemplos de agentes que circulam livremente entre todos estes espaços, há muitos que restringem sua circulação por conta de conflitos (pessoais ou familiais) ${ }^{160}$. Os agentes configuram, por isso, uma espacialidade para as interações e distinguem-se pelo café que frequentam. O Café do Tavares atrai a frequentação da maioria, entre outros motivos, porque é mais antigo. O pai de Tavares já havia sido dono de uma taberna na aldeia ${ }^{161}$. Já o Café de cima é muito mais recente. Foi aberto pela senhora Afonsina depois que retornou do período que passou emigrada trabalhando na França, na produção agrícola, próxima a Paris ${ }^{162}$. Ela é membro de uma tradicional família da aldeia, bastante envolvida com a política local. Assim, frequentam o Café de cima todos aqueles que têm algum tipo de proximidade com essa família, ou ainda aqueles que têm algum tipo de rivalidade com frequentadores do Café do Tavares.

160 Em sua análise sobre a freqüentação dos cafés em aldeias do norte português, Miguel Vale de Almeida assinala que "no café, está-se exposto também aos 'inimigos': por vezes é o café x, onde nunca se entra por causa de um conflito com o dono ou sua família” (2000:185).

161 Os Cafés, apesar de serem aqui tidos como espaços de sociabilidade próprios da dimensão profana da festa, têm elementos discretos que remetem ao sagrado. O Café de cima possui um canto decorado com quadros e fotos do santuário da aldeia. O Tavares, por sua vez, nunca pode ir à festa por conta de seu compromisso com o Café, que se mantém aberto. No entanto, revelou possuir uma extensa coleção dos pôsteres de divulgação do cronograma da festa. Distribuídos pelo comércio local e dos arredores, Tavares sempre guarda com cuidado o exemplar que fixado nos vidros da porta de seu Café.

162 Vale destacar que a senhora Afonsina emigrou por meio da intermediação e auxílio da senhora Aline, que havia se instalado na França há mais tempo. 


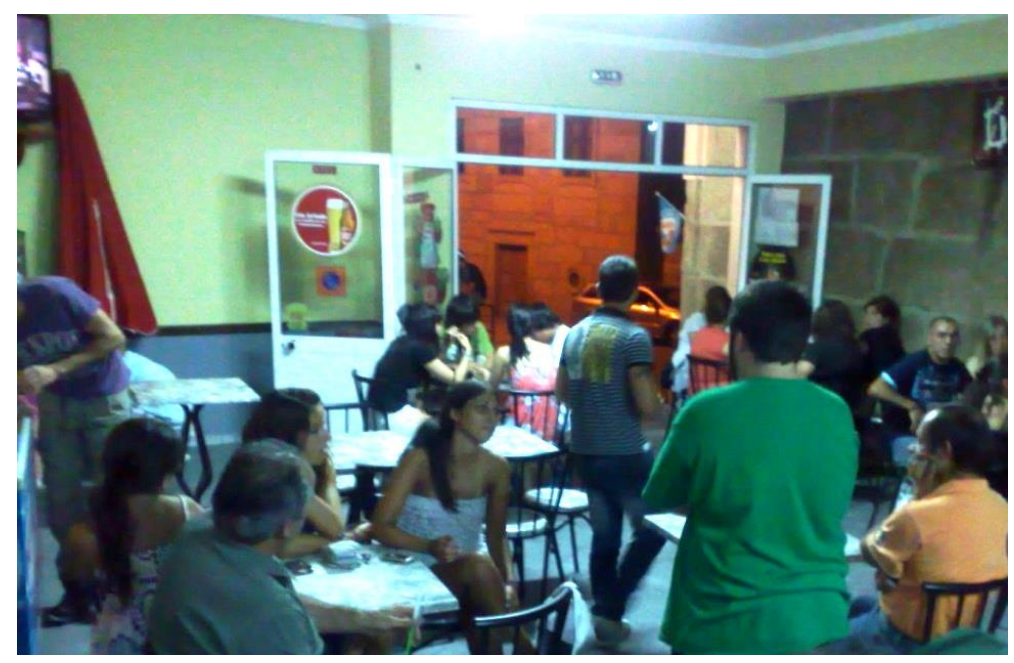

Figura 6. Café do Tavares em momento de grande frequentação nos dias que antecedem a procissão.

Situações de sociabilidade pura e lazer

É importante, de toda forma, também perceber que no Café não estão em jogo apenas tensões. Não se trata apenas de um espaço de rivalidades, mas de construção de proximidades. Nos Cafés desenvolvem-se sobretudo as interações de lazer, de "sociabilidade pura", dimensão das práticas ali desenvolvidas que mais lembra Georg Simmel quando afirma que, para além dos conteúdos específicos que caracterizam as interações, há uma enorme satisfação atendida pelo simples fato de se "estar junto", ocasionada pela sociação em si mesma. É na sua qualidade formal que a interação durante a festa adquire sua dimensão lúdica mais visível, é quando "nada se deve buscar além da satisfação desse instante - quando muito, de sua lembrança" (SIMMEL, 2006: 66). Isso figura, por exemplo, numa fala icônica que surgiu de maneira fortuita, numa conversa informal e casual com Zeca ${ }^{163}$ no Café do Tavares:

Olha, um gajo que esteve cá a infância e depois vai para longe, passa um ano ou mais sem cá estar, incomoda-se. Na França estou sempre a pensar nisso, nas pessoas com quem convivi. Depois cá estamos nesta

163 Zeca tem por volta de quarenta anos e mora na França com André, seu irmão, há aproximadamente uns quatro anos. 
altura [das festas] e faz-me muito gosto estar com os amigos, aqueles mais próximos, com quem aprontei muitas coisas desde quando crianças. Daí nos pomos a falar e a lembrar. E sempre que nos botamos a conversar lembramos mais coisas, isso nunca se esgota e todo ano repetimos! Estamos o ano todo a esperar por isso. Um lembra-se de algo, outro de outra coisa, e vamos assim a rir-nos do passado ${ }^{164}$.

Essa sociabilidade nos Cafés representa a dimensão verdadeiramente profana da festa. Cabe considerar aqui que, conforme pude observar em outras etapas da pesquisa, a vida nos contextos de destino é em geral bastante comedida ${ }^{165}$. Além de a própria observação revelar a intensidade das interações nesse espaço, vale destacar algumas das interações que tive nesse espaço. Inácio ${ }^{166}$ foi alguém com quem estabeleci um diálogo mais constante e que ressaltava a todo instante a dimensão de lazer que esse período representa para o emigrante, tanto nos espaços de consumo, como o Café, quanto em outros espaços da freguesia.

Contrastando aspectos de sua vida na França com o período de férias na aldeia, podemos caracterizar esse como um tempo de fruição, de lazer imoderado como oposição à vida na sociedade de destino ${ }^{167}$. Segundo ele:

164 Observar os instantes de rememoração coletiva é uma oportunidade de pesquisa que revela, com fluidez, experiências compartilhadas no passado, a partir de contextos (passados e presentes) plenos de signos e significados, investidos e cambiados.

165 Conforme afirma Caroline Brettell (2003: 69), o aldeão do nordeste português emigra com o intuito de ser "travalleur" na França para poder ser "petit bourgeois" em Portugal.

166 Inácio tem quarenta e oito anos e é filho da senhora Aline. Vive na França desde seus dezoito anos e trabalha como marceneiro de telhados. Mais detalhes sobre a interação com dona Aline e sua família são descritos no primeiro capítulo.

167 Nos Cafés acontecem esporadicamente festas de modo imprevisto e espontâneo. José, imigrante na França, é sempre exortado a trazer sua "concertina”, instrumento musical, uma espécie de sanfona. Algumas vezes outros agentes surgem com "guitarras" (violões). Sempre que alguém toca alguma música, um ambiente festivo se forma imediatamente e as pessoas cantam e dançam. 
Na França não é como aqui! Acorda-se sempre muito cedo para trabalhar e também por isso nunca saímos de casa. Os Cafés fecham cedo e é do trabalho para casa, de casa para o trabalho. Nos finais de semana ainda nos encontramos nas Casas de Cultura Portuguesa para jogar cartas, comer e beber algo. Mas a vida lá é isso: estar sempre a juntar, a amealhar, para poder cá vir todo ano. Aqui podemos tomar uma cerveja a mais, o custo de vida é muito menor ${ }^{168}$.

Por fim, cabe ainda apontar que quando relações de proximidade se reproduzem e reafirmam nesse espaço de interações, uma série de possibilidades se abre: é o momento em que se processa intensamente uma troca de informações. Nesse instante preciso a diáspora está também se reconfigurando. Quem está bem alocado no contexto de destino, convida outros que pensam em emigrar. Quem está insatisfeito com as condições de trabalho e o custo de vida do lugar no qual se instalou, testa hipóteses de reorientar sua trajetória. Os Cafés são, portanto, espaços praticados pelos emigrantes e por isso marcados também pela dinâmica emigratória, atravessados pelas tensões engendradas por meio das distinções agenciadas, muitas vezes conflitivas ou ao menos fundamento de uma sociabilidade agonística, mas também pela realização da sociabilidade em sua dimensão lúdica e sociativa.

Pela aldeia e o restante da freguesia (circulação, trabalho e lazer)

Nesta subseção procuro pensar de modo mais alargado as práticas de lazer compartilhado por migrantes e residentes. Aqui enfoco as práticas por toda a freguesia, tais como as festas em aldeias vizinhas e idas conjuntas às margens do rio Tua, na Ribeirinha ${ }^{169}$. Tento demonstrar como o contexto festivo se dissemina de modo geral por diversos espaços apropriados e praticados.

\footnotetext{
168 É preciso, no entanto, matizar essa afirmação. Reflexões sobre as práticas de trabalho e lazer na França são feitas no capítulo 3 .

169 A Ribeirinha é uma pequena aldeia vizinha, pertencente à freguesia de Vilas Boas, tal como referida na introdução.
} 
As demais festas do concelho

Diversas festividades acontecem em diferentes lugares nesse contexto. Uma breve caminhada pela região é suficiente para perceber a grande quantidade de folhetos e anúncios, geralmente fixados nos comércios, sobre a realização de festas diversas nas proximidades.

Uma das quais pude participar e presenciar foi a da Ribeirinha, denominada (como muitas outras nessa época) "Festa do Emigrante" ${ }^{170}$. A Ribeirinha é uma aldeia menor da freguesia, tem menos habitantes que Vilas Boas. A festa não tinha tantas pessoas, por volta de uma centena. Pude reconhecer muitas das pessoas que ali estavam, grande parte delas emigrantes de Vilas Boas que eu havia conhecido em outros contextos de interação.

Dançava-se ao som de uma banda, entre outras coisas, algumas músicas brasileiras e, sobretudo, música "pimba" ${ }^{171}$. Os mais jovens, envergonhados, escondiam-se nos fundos e bordas da multidão. Trata-se de uma pequena festa que se faz a reboque da festa de Vilas Boas, a fazer proveito da presença e do dinheiro dos emigrantes.

Além da dança no chão de paralelepípedos e areia em frente ao palco, há sempre jogos de azar. Sorteio de prendas por preços módicos em rifas, arremesso de bolas de meia em latas marcadas com os escudos das equipes de futebol mais populares do país e, principalmente, um leilão. O leilão, na verdade, consiste numa brincadeira. Um animador anuncia o leilão de uma peça secreta, embrulhada em jornal, sempre de modo

170 Essas festas que surgem na ocasião do retorno massivo dos emigrantes demonstram quanta expectativa se concentra em torno desse evento. Vi anúncios de outras festas para os emigrantes. Uma delas anunciada em carros de som, se passou em Macedo de Cavaleiros, cidade de médio porte próxima do concelho de Vila Flor. Essa festa atraiu quantidade significativa dos emigrantes de Vilas Boas porque teve como atração principal o já mencionado cantor Lucenzo, mundialmente conhecido e originário de Vilas Boas.

171 Música popular muito executada nas festividades de verão e denominada "pimba" de modo pejorativo, para indicar o caráter malicioso e dúbio de grande parte das letras das canções. É geralmente executada pelos "grupos de baile", conjuntos musicais que se dedicam exclusivamente a tocar nas festas populares do interior de Portugal durante o verão. A esse respeito ver Lemos Monteiro, 2012. 
muito animado e jocoso. Não é possível saber do que se trata o prêmio. Os lances começam de modo tímido, mas logo se acirram, iniciam uma espécie de disputa. Os emigrantes insuflam os lances.

Na ocasião em que presenciei o leilão, o vencedor dos lances foi André, que pagou cinquenta euros pelo prêmio. Ele foi chamado ao palco para receber o prêmio e abri-lo diante de todos. Ao abrir, o riso foi generalizado. Tratava-se de uma caneca em forma de pênis, para cerveja ${ }^{172}$. André se divertiu com o prêmio e, juntamente com seus amigos, passaram a beber cerveja e fazerem insinuações jocosas uns aos outros para que bebessem na caneca, numa forma de interação intensamente lúdica. Essa ocasião extremamente excepcional é indicativa do aspecto sacrificial da festa, que sempre envolve formas de dispêndio. Nesse aspecto a festa aproxima-se da definição apresentada por Lea Perez quando diz que a festa advém da confluência de três elementos:

"um grupo em estado de efervescência coletiva (leia-se fusão coletiva e efervescência) que consagra sua reunião a alguém ou a uma coisa (toda festa é sacrifício) e que, assim procedendo, liberta-se das amarras da temporalidade linear e da lógica da utilidade e do cálculo, pois a festa é uma sucessão de instantes fugidios, presididos pela lógica do excesso, do dispêndio, da exacerbação, da dilapidação. Em resumo: a festa instaura e constitui um outro mundo, uma outra forma de experienciar a vida social, marcada pelo lúdico, pela exaltação dos sentidos e das emoções - com um forte acento hedonista e agonístico" (2002: 19)

A rua, coberta pelo escuro imenso da noite e muitas bandeirolas trêmulas de papel colorido, é ocupada pelas pessoas comemorando juntas, iluminadas pelo palco em uma carroceria de caminhão, repleta de parafernália eletrônica. A festa de Ribeirinha, portanto, é permeada pelo peso dos jogos, da interação marcadamente jocosa. Sua referências se ligam sobretudo ao universo da música pimba, popular, de apelo eróticocômico, e por isso distingue-se fundamentalmente da festa de Vilas Boas, que tem um

\footnotetext{
172 Sobre a popularidade desses artefatos fálicos na cultura popular portuguesa, ver Pina Cabral, 2003, pp.55-87.
} 
fundo religioso e, embora admita uma grande parcela de entretenimento profano, é marcada pela intercalação entre momentos do sagrado e do profano, festa e bailarico ${ }^{173}$.

- 4.3 UMA ECONOMIA DE DONS: TEMPORALIDADES E DINÂMICAS DA FESTA

Tempos de festas. O rito e o lúdico (entre procissões, cortejos e bailaricos)

Aqui inicio a etnografia da festa propriamente dita. Este ponto do trabalho se concentra nos três dias de festividades, com uma descrição mais atenta aos detalhes estéticos. Procurarei descrever todo o processo ritual de preparação da procissão, a sequência e simbologia dos andores, a hierarquia e os interesses envolvidos na organização da festa, a participação mais ou menos ativa na procissão, a música e uma temporalidade que alterna ritual religioso e baile. Dessa forma se completa uma descrição do retorno e do engajamento dos diferentes agentes da pesquisa na vida social da aldeia.

São, no total, quatro procissões nesse período. A primeira delas ocorre logo no começo do mês e é denominada "procissão de descida", porque é o momento em que a imagem de Nossa Senhora da Assunção é trazida solenemente do santuário até a aldeia pela comunidade. A segunda é chamada de "procissão das velas" e acontece um pouco antes do fim da novena. Nessa procissão a imagem trazida para a aldeia anteriormente é levada em procissão para circular pela aldeia. A terceira procissão demarca o encerramento da novena e do período de preparação religiosa da festa. Por fim, a última procissão é, na verdade, um imenso cortejo, repleto de andores, estandartes e grupos de fanfarras, com milhares de pessoas. A quarta procissão, portanto, aponta o auge das práticas religiosas e das celebrações e ocorre no dia quinze de agosto, em que, segundo o calendário católico mariano, é celebrada a assunção da Virgem Maria.

Ademais, procuro também produzir reflexões sobre festa em seu âmbito que podemos denominar "profano", ou seja, a celebração fora da esfera religiosa oficial, a

\footnotetext{
173 Discutirei esse tema a seguir, no trecho final do capítulo.
} 
experiência e vivência da festa nos espaços de sociabilidade, principalmente nos bailes, destacando como a festa se orienta e organiza por meio de uma sucessão de eventos que intercalam o calendário da igreja e o tempo do bailarico.

\section{A abertura do calendário religioso: cortejo de descida}

O primeiro domingo de agosto é o dia em que se realiza a descida da imagem de Nossa Senhora da Assunção de seu santuário, no cimo do monte, para a igreja de Santa Maria Madalena, no miolo da aldeia. Esse rito inicial abre o calendário religioso do mês e é sucedido por uma novena que se estende até as vésperas da festividade maior, nos dias quatorze e quinze.

A procissão de descida da imagem da santa até a aldeia é um evento de destaque, que atrai a participação de parte dos emigrantes, daqueles que conseguem retornar para a aldeia com antecedência suficiente para acompanhar todo o calendário festivo. Nesse momento as pessoas sobem até o santuário de onde depois descem acompanhando o cortejo processional atrás de pequeno andor para a estatueta religiosa, dois estandartes vermelhos e um grande crucifixo de madeira, carregados por voluntários que em geral participam das atividades da igreja ${ }^{174}$.

\footnotetext{
174 Pude perceber, por meio da observação, que não são todos os emigrantes que se envolvem nas atividades do calendário religioso. No entanto, também reparei que alguns migrantes têm grande interesse em reforçar sua participação nos eventos. Marcos, por exemplo, que vive na Espanha, próximo à fronteira com a França, foi responsável por carregar um dos estandartes das procissões de descida e subida nas duas ocasiões em que fiz trabalho de campo no período festivo. Ademais, há uma certa disputa em torno da participação em outras ocasiões, sobretudo no que se refere à tarefa de carregar os andores pelo monte acima no cortejo do dia quinze. Voltarei a esse tema adiante.
} 


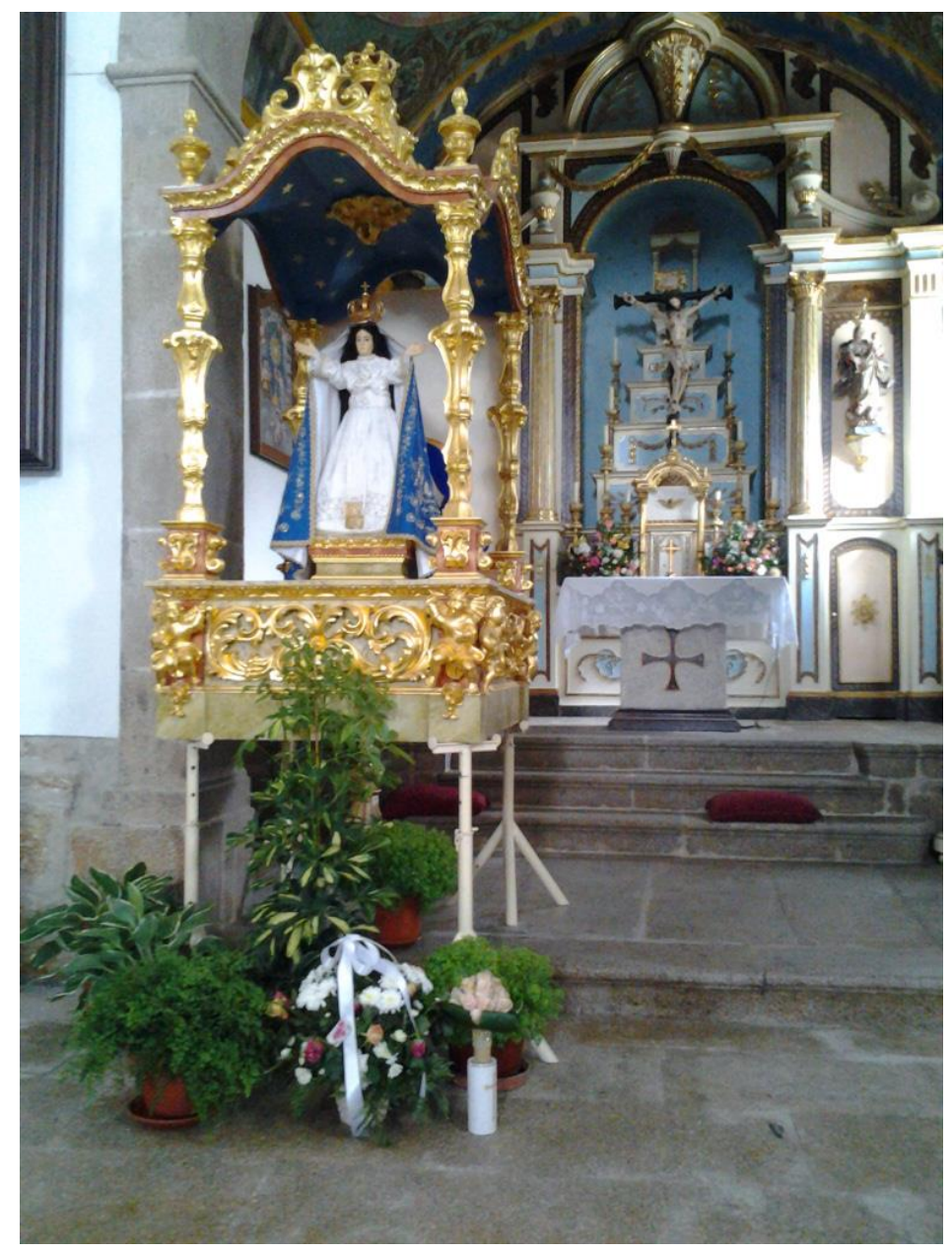

Figura 7. Pequena cúpula em que fica acomodada a estatueta de Nossa Senhora da Assunção ao lado do altar da Igreja de Santa Maria Madalena até a procissão do dia quinze de agosto.

Pelo caminho, o padre reza rapidamente um rosário seguido pelos fieis e, entre os conjuntos de orações insere comentários que se referem aos milagres da santa. O grupo de pedestres que acompanhava o andor a procissão, nas duas ocasiões observadas, foi significativo, mas vale destacar também a presença de automóveis que seguiam lentamente a procissão.

A essa altura das comemorações, nas duas oportunidades em que pude acompanhar o cortejo (nos anos de 2011 e 2012), notei que a quantidade de emigrantes é já significativa. Isso se torna perceptível tanto pelas interações observadas entre os agentes quanto pela quantidade de placas de diferentes origens nos automóveis que passam a circular com intensidade pela aldeia. 
Enquanto a procissão descia e entoava as rezas e cânticos, soava o sino do santuário em ritmo muito pausado. Eram quase oito horas da noite e o sol ainda se punha, tingindo os campos em volta de vermelho. Só anoiteceu verdadeiramente quando a procissão já havia cumprido seu trajeto e chegado à igreja da aldeia, que se encheu para uma missa de encerramento cujo sermão apelava para que a celebração das festividades que estavam sendo preparadas não se tornassem algo mecânico, esvaziado de sentido religioso, tomado pelo consumo e pelo deleite da dimensão profana da festa.

$\mathrm{O}$ andor em que a estatueta da santa foi trazida fica repousado no adro da igreja, ao lado do altar, voltado de frente para quem entra no recinto. Nesse espaço, em torno do andor e da imagem que ele carrega, é que se realizará posteriormente a novena dedicada a Nossa Senhora da Assunção. Muitas pessoas vêm admirar, fotografar e rezar em frente ao andor nos dias que decorrem até a grande e aguardada procissão de subida.

Sobre esse período é importante dizer também que é o momento em que se realiza o catecismo e primeira comunhão de crianças ${ }^{175}$. Em 2012 oito crianças passaram pelo catecismo, dentre as quais seis são de famílias emigrantes e aproveitaram a ocasião de retorno para participação no ritual na aldeia ${ }^{176}$. A ocasião de primeira comunhão das crianças é motivo de grande celebração familiar, de grande comemoração ${ }^{177}$. Naquele ano, além das festas de que tive notícia, realizadas nas casas dos grupos familiares, uma das famílias reservou a "Casa do Povo", espaço no fundo da aldeia sede da Junta de Freguesia, para festejar a primeira comunhão do seu membro mais jovem. As crianças concluem o catecismo com a primeira comunhão e, logo em seguida, cumprem uma função especial no cortejo final, desfilando na dianteira da procissão fantasiados como

\footnotetext{
175 Um sentimento de nostalgia bastante forte marca as lembranças dos aldeões sobre a festa. Muitos costumam afirmar que a festa tal como é celebrada atualmente é muito menor do que no passado, quando foi verdadeiramente grandiosa. Nesse sentido é que também se referem à primeira comunhão das crianças, afirmando que no passado o número de crianças que passava por essa iniciação religiosa era muito maior.
}

176 Como exemplo desse fato, vale destacar que as duas filhas de André, segundo ele disse, foram batizadas e passaram pelo catecismo na aldeia.

177 A primeira comunhão de uma criança é um evento que concentra muitos esforços de um grupo familiar. O núcleo familiar no qual participa a criança em questão muitas vezes assume a responsabilidade de realizar uma festa que reúne dezenas de familiares com graus distintos de parentesco e proximidade. 
anjos, figuras bíblicas e, além do mais, revezando o direito de carregar o pequeno "andor do menino Jesus", mais leve e que transporta apenas alguns ornamentos e a figura de Jesus Cristo recém-nascido.

Por fim, ao notar a participação dos emigrantes nas atividades religiosas da aldeia no mês de agosto, surgiram ainda alguns questionamentos sobre a atividade religiosa dos emigrantes nos seus contextos de destino. A família de André, por exemplo, posso dizer que não frequenta a igreja na França. Laura justificou o fato dizendo que "lá [na França] é um bocado diferente. Não se compreende tudo e não apetece ir. Não é a mesma coisa". A família de Rosa, que vive em Bordeaux, também afirmou não participar ativamente da igreja na França. Embora existam exemplos contrários, como o da senhora Brigite, a religiosidade parece também conter uma característica marcadamente local. Portanto, para o migrante não se trata de professar um catolicismo institucional e indiferenciado, mas de um catolicismo repleto de afetos e identificações em sua expressão local e popular.

\section{A procissão das velas}

A procissão das velas leva a imagem de Nossa Senhora da Assunção em um percurso por entre as ruas e casas da aldeia. Ocorre por volta do dia dez de agosto e é, como as outras procissões menores, incomparável à magnitude do cortejo do dia quinze. A estatueta é levada em cima do mesmo pequeno andor em que foi trazida do santuário, carregado nos ombros de voluntários. O percurso passa por quase todas as ruas do centro do povoado e mais uma vez se reza o rosário no caminho. A procissão parte da igreja matriz, onde estava repousado o andor com a imagem, e retorna para o mesmo lugar. É como se a santa fosse apresentada à aldeia e aos aldeões. As velas representam homenagens e preces.

Acompanhei o percurso na companhia de Damião. Enquanto caminhávamos, Damião apontou algumas pessoas com quem tem relações de parentesco não acionadas. Segundo ele, são da parte da família de sua mãe, que faleceu quando ele era apenas um bebê, e que por isso teriam lhe ignorado. Nesse quadro notei que existe também uma maneira de se relacionar com o espaço da aldeia muito marcada pelas relações de cada 
agente. Em certo sentido, a utilização que cada agente faz do espaço aldeão está diretamente associada às relações construídas e sustentadas, que demarcam espaços de circulação e espaços de certo modo interditos.

\section{Procissão de encerramento da novena}

A procissão de encerramento da novena se dá por volta do dia doze e consiste fundamentalmente em uma caminhada monte acima, sem dessa vez a imagem de Nossa Senhora ser carregada.

O percurso parte da base do monte em que se situa o santuário e sobe lentamente, fazendo pausas em partes do monte relacionadas às histórias locais dos milagres. Em 2011 o percurso seguiu uma trilha antiga, próxima ao bosque de eucaliptos, onde executou uma pausa no cruzeirinho que demarca o ponto no monte em que foi registrada uma aparição da santa à menina. Logo em seguida, a procissão acessou uma escada lateral por onde subiu até o santuário e deu uma volta à igreja onde, por fim, entrou, ouviu-se um sermão e uma oração que encerraram a novena e, enfim, concluíram-se os preparativos para a festa que aconteceria dias depois.

Nessa procissão fui acompanhado por João, que reside na aldeia. Ao final da procissão, durante a missa que se iniciou, ele olhou para a igreja completamente lotada e iniciou o seguinte diálogo comigo a partir de um comentário:

João: - Olha em volta, olha para aqui na igreja: são quase todos emigrantes.

Eu: - E como sabes? Conhece-os quase todos?

João: - Não, mas isso percebe-se logo.

Eu: - Como?

João: - Percebe-se... por como se vestem, porque aqui e ali falam francês. Enfim, percebe-se... 
Esse diálogo fez pensar a respeito das formas absolutamente naturalizadas de distinções sociais produzidas no contexto do campo social transnacional, inúmeras vezes sutis. Formas percebidas pelos agentes e que são verdadeiras chaves da compreensão que esses sujeitos têm do mundo construído a partir de suas relações. São diferenças que se produzem em significações miúdas, indiciariamente e que operam continuamente. Ao notar característica semelhante em sua pesquisa, Caroline Brettell (2007) assinala um aspecto relevante das relações entre emigrantes e residentes quando discute o papel que cumprem as remessas (principalmente dinheiro) que os emigrantes comumente enviam para a aldeia como forma de suporte econômico à família que permaneceu em Portugal na constituição de diferenciações significativas. Embora formalizem uma prática sistemática de auxílio,

\footnotetext{
"no curto prazo as remessas frequentemente encorajam nova emigração porque acentuam as diferenças entre migrantes que 'têm' e nãomigrantes que 'não-têm' ou que ficam para trás porque os desafios econômicos e, devo acrescentar, o sistema local de prestígio mudam" (BRETTELL, 2007:55, tradução minha).
}

As diferenças sócio-econômicas, portanto, acabam emergindo como traços capazes de, a partir de um ponto de vista êmico, produzir distinções significativas entre os que ficam e os que partem.

Em 2012, no entanto, o trajeto da procissão de encerramento da novena foi um tanto diferente. Sem ter subido o último lance de escadas, a procissão encerrou-se no novo pátio construído antes do topo, onde há uma espécie de palanque em que é improvisado um altar para a mensagem de encerramento. Isso porque nesse ano, ao fim das orações, houve um evento relacionado à comemoração dos quinhentos anos da carta foral que emancipou Vilas Boas do domínio político de Mirandela. As lideranças políticas locais haviam, em outro momento do ano, organizado uma festa para comemorar o documento cedido pelo rei D. Manuel I que separou Vilas Boas como um concelho politicamente independente, reconhecendo neste fato histórico uma espécie de data de fundação da freguesia. Naquele momento foi exibido um filme produzido por ocasião dessa comemoração e apresentado pela primeira vez aos presentes, aldeões e emigrantes. 
Essa festa mobilizou praticamente todos os aldeões. Cada um recebeu uma espécie de fantasia para se caracterizar como personagem medieval. A aldeia foi decorada, alguns elementos cenográficos foram acrescentados, atores também foram contratados, e parte dos aldeões foi mobilizada em encenações que tinham como objetivo reconstituir práticas da Idade Média. Essa solenidade durou um dia inteiro e foi acompanhada de música e alimentação. Toda essa pequena festa excepcional tinha como objetivo principal inaugurar uma estátua em do rei D. Manuel como referência ao foral, trazendo na base da estátua de pedra uma placa de metal com a transcrição do documento festejado.

É importante notar que essa recuperação estratégica da história é uma iniciativa do poder local de formular um passado e demarcar um momento de origem política da aldeia. Esse intento, no entanto, mais do que encerrar-se sobre a própria aldeia, foi recuperado ao final da procissão de encerramento da novena, como forma de apresentar ao contingente migrante a celebração que havia ali ocorrido.

Uma exposição sobre o evento foi criada no espaço do pequeno museu que foi recentemente construído para o santuário. Foram expostas fotos em preto e branco em grandes formatos em um salão reservado, sem para isso tomar o espaço do acervo de fotos do santuário em exposição permanente. Os visitantes tinham a possibilidade de adquirir qualquer uma das fotos em formatos menores, ou até mesmo o DVD do filme apresentado a eles anteriormente, no final da procissão. Esse evento, além do mais, aumentou a captação de renda que ocorre no período da festa. Sua divulgação no período festivo não foi meramente fortuita, mas teve como objetivo principal expor para o contingente migrante a comemoração incomum, o que em certo sentido aponta para a relevância do contingente migrante para a realização de quaisquer eventos, tanto no que representam como público, quanto pelo dinheiro que fazem circular durante o período que retornam.

A aproximação e realização do grande cortejo

Conforme a datas das celebrações se aproxima, a intensidade da vida social cresce e os eventos significativos se multiplicam. Por conseguinte, se intensifica proporcionalmente a atividade de observação etnográfica. Esse período liminar de grande expec- 
tativa é preenchido pelos agentes com atividades diversas, sejam de lazer ou ainda pequenas tarefas. O tempo que os emigrantes passam na freguesia durante o período de retorno é em parte ocupado com essas atividades.

Boa parte dos agentes se concentra em realizar reuniões e encontros familiares, visitar algum parente, se divertir no rio Tua, lugar de memórias, ou na piscina pública de Vila Flor, sempre cheia nesse período. Outra parte, no entanto, se concentra em atividades domésticas. Enquanto alguns se ocupam com pequenos reparos em suas casas, outros se concentram em atividades maiores, se esforçam para avançar o quanto for possível a construção que realizam lentamente de uma casa na aldeia. A construção de uma casa é um dos principais investimentos do emigrante. São tão suntuosas quanto possível e muitas vezes constituem outro sinal relevante do sucesso que conquistaram na emigração. A casa de uma família emigrante é um sinal permanente de sua presença no seio da aldeia ${ }^{178}$. É comum que os demais aldeões e emigrantes saibam a que família pertence cada casa construída.

Aproveitei o intervalo entre o fim da novena e o início das festividades para realizar caminhadas pela aldeia ${ }^{179}$. Foi dessa maneira que iniciei interações significativas com alguns agentes citados nessa pesquisa. Na verdade, em diversas dessas ocasiões, fui interpelado por algumas pessoas após cumprimenta-las. A primeira pergunta que me interpuseram foi "você é parente de quem?". Tal como sugere John Comerford ao se referir às suas interações em trabalho de campo em zonas rurais do estado de Minas Gerais, "essa maneira de abordar um estranho percorrendo essas localidades rurais revela um pressuposto: a princípio, quem circula nessas localidades ou é morador do lugar ou é parente de morador" (2003: 30).

\footnotetext{
178 Tal como afirma Machado sobre as remessas de dinheiro enviadas para os contextos de origem, "a sensação é que o dinheiro não substitui a presença, mas indica pelo menos que num futuro incerto as pessoas da família reunir-se-ão novamente" (2009: 159), essa lógica é em alguma medida equivalente para as casas construídas pelos emigrantes em Vilas Boas, já que constituem o que o autor denomina de "bem totêmico" (Idem). Em sentido semelhante, Machado afirma ainda que "a casa é um valor moral, mais do que um desejo material" (2010: 12).

179 Voltei a utilizar essa estratégia de observação após o término das festividades como forma de notar possíveis diferenças significativas na dinâmica da aldeia e no fluxo de pessoas.
} 
Esse tipo de abordagem é significativa para pensarmos como se estruturam as relações tanto na aldeia quanto em todo o espectro do campo social transnacional. Mariana, filha de André, foi quem primeiro afirmou, comentando esse aspecto, "a aldeia é uma família" ${ }^{180}$, ou seja, que na aldeia todos se conhecem em termos das relações de parentesco, consideração, estima ou conflito. No entanto, no caso aqui observado, mais do que uma operação genealógica, esse reconhecimento do lugar do interlocutor passa continuamente por um mapeamento do campo social transnacionalmente constituído. $\mathrm{O}$ reconhecimento de uma pessoa, mais do que por meio de suas relações de parentesco, se dá pelo reconhecimento de sua trajetória. Nesse sentido, a segunda pergunta questiona algo a respeito de como se tem passado a vida no local para o qual se emigrou. Como se trata, à primeira vista, de um grupo social deslocalizado pelo espalhamento populacional, estas são operações de localização, ou ainda de reconhecimento de localidades e mapeamento de destinos migratórios ${ }^{181}$.

Com o fim desse curto período intersticial, inicia-se um período acelerado, que se intensifica rapidamente com a aproximação do momento de auge das comemorações.

Aqui é possível pensar as potencialidades do que John Comerford chama de "territórios de parentesco" (2003: 30). A esse respeito Comerford diz que: "perguntar sobre seu parentesco com alguém da localidade revela ainda o esforço dos moradores dessas localidades de tentar localizar um "estranho" que tem alguma relação com o mundo local (...) em um esquema de enquadramento social" (Idem: 33). Em sentido semelhante ao por mim percebido, o autor ainda nota que "nas localidades rurais (...) diz-se, em algumas circunstâncias (diante de pessoas de fora que perguntam sobre as famílias do lugar, por exemplo), que "aqui todo mundo é parente" (Ibidem: 34 ).

181 Cabe, entretanto, lembrar que o diz Comerford quando analisa os casos de deslocamento de famílias: "mas é importante lembrar também que o fluxo 'para fora' e eventualmente de volta 'para dentro' das localidades é acompanhado com cuidado e interesse pelo público da localidade, de modo que deslocar-se para fora da localidade não significa imediata ou necessariamente sair do campo de observação/informação/julgamento do círculo social ao qual pertence a família. As pessoas sabem para onde foram seus parentes e os parentes dos outros, o que fizeram e deixaram de fazer, avaliam seus sucessos, fracassos, dramas, retornos. (...) Em boa medida, os segmentos das famílias que se mudam para outras localidades rurais, cidades da região ou de fora, mantém-se em algum grau e em algumas circunstâncias investidos das prerrogativas e da co-responsabilidade que caracterizam o pertencimento e que implica na inclusão nos mapeamentos. Dessas pessoas e famílias em lugares distantes cuja localização a cada momento se acompanha com interesse, se fala com orgulho, desdém, tristeza, maldade" (2003: 43-44). 
Adiante procedo a uma descrição do desenrolar dos dias festivos por meio das práticas e interações dos agentes.

\section{Dia de emigrante, dia de aldeão}

Neste instante do texto reflito por meio de descrições sobre as peculiares e significativas diferentes espécies de participação nos dias de festividade.

Os dois principais momentos da festa são os dias quatorze e quinze de agosto. Ambos são importantes e constituem uma espécie de oposição: enquanto o dia quatorze concentra a dimensão profana da comemoração, o dia quinze, por sua vez, se destaca pela realização do grande cortejo em homenagem à Nossa Senhora da Assunção. Ocorre nesses dias propriamente festivos algo como uma suspensão do cotidiano. A aldeia é agitada por uma movimentação excepcional (de automóveis, motocicletas e pessoas), os Cafés vivem a aglomeração e o falatório desses dias quentes que se opõem à monotonia do inverno ${ }^{182}$. É uma efervescência que se mantém latente por toda a extensão das semanas, embora seja excedida nos aguardados dias da comemoração local.

O dia treze não tem nenhuma atividade programada pela Igreja, e constitui apenas um prenúncio do arraial: a feira começa a ser montada, a praça de alimentação se instala e ocorre um primeiro baile, de menor proporção. Algumas barracas da feira são montadas sem grande pressa. Começam a chegar os primeiros ônibus transportando peregrinos. Outra parte dos peregrinos começa a chegar caminhando e podem ser identi-

\footnotetext{
182 Essa oposição entre as características da atividade social no verão e no inverno é destacada por alguns autores na teorização sobre a temporalidade imposta pelas estações do ano, principalmente na porção rural de Portugal (BRITO, 1996; LEAL, 1996). No entanto, devido à dinâmica de retorno cíclico dos emigrantes em suas férias de verão, essa distinção se acentua e reproduz com novas características, menos relacionadas às marcações da agricultura. A dinâmica transnacional, portanto, repõe o binarismo entre a intensa atividade do verão e o repouso do inverno, o que se confirma por meio do discurso nativo. João continuamente insistia nessa oposição: "Isso que vês aqui [na aldeia], não é sempre assim. Os emigrantes estão aqui no verão, mas quase não os vemos no resto do ano. Depois que eles se vão, a aldeia fica vazia e assim é que passa o ano". É preciso, no entanto, matizar essa oposição entre verão e inverno, já que o Café, segundo afirmou João e pude observar, continua sendo frequentado pelos residentes da aldeia em outros momentos, porém de modo muito menos intenso, mais disperso e ocasional.
} 
ficados pelos coletes fluorescentes obrigatórios ${ }^{183}$. No entanto, a maior parte dos peregrinos chega somente nos dois dias seguintes. Uma quantidade grande de emigrantes começa a chegar do dia treze em diante.

Contudo, é destacável nesse quadro que a própria temporalidade da festa torna diferentes os modos de participação em cada um dos dois principais dias. Há diferenças significativas no baile de cada um desses dias e mesmo nos grupos de pessoas presentes em cada um. João repetiu algumas vezes, de modo levemente diferente, que

a festa mesmo ocorre no dia quatorze. $O$ dia quinze é mais religioso e o principal é a procissão, não o baile ${ }^{184}$.

As palavras de João indicam algo que a observação da festa em ambos os dias foi de extrema relevância para captar e demarcar algumas dessas diferenças. A festa da véspera é, em geral, marcada pela presença mista de aldeões e emigrantes. É o baile do dia quatorze que atrai um número maior de participantes e, por isso, o mais capaz de promover um contexto de efervescência coletiva.

O monte é quase ocupado como um todo: as pequenas capelas dispostas ao longo da subida são visitadas, as ladeiras de paralelepípedos e os caminhos até a entrada da aldeia (que fica esvaziada durante a festa no santuário), a feira, os pátios da praça de alimentação e do palco, a Casa dos Milagres ${ }^{185}$ e a sala para venda de artigos religiosos, as escadarias e, por fim, a própria igreja do santuário, que permanece com todas as por-

183 Os coletes em cores chamativas são uma medida de segurança, já que facilitam a visualização dos peregrinos pelos motoristas de veículos durante sua caminhada noturna.

184 Dinâmica semelhante se observa nas festas dos santos populares nos bairros históricos de Lisboa, quando a procissão de Santo António serve de contraponto no dia seguinte a todo o investimento competitivo investido nos desfiles das marchas, tal como descreve Graça Índias Cordeiro (1997: 323).

185 A Casa dos Milagres é um recinto comum em santuários de peregrinação. Nelas são vendidas velas de diferentes tipos e outros artigos para o cumprimento de promessas. Há um espaço reservado ao lado da Casa dos Milagres onde as velas podem ser acesas. Parte das velas, no entanto, é levada durante a grande procissão do dia quinze. As velas podem possuir o formato de alguma parte do corpo humano, conforme a promessa se refira a algum pedido de cura, ou podem ainda ter formato de crianças de diversas idades, para caso a promessa a ser cumprida se refira à saúde de alguma criança ou mesmo ao desejo de alguma mulher poder engravidar. 
tas abertas para visitação, ficam repletos de gente. A igreja é ocupada por pessoas que a fotografam com detalhes, rezam e meditam em um profundo silêncio, que contrasta com a agitação do baile alguns lances de escada abaixo dali.

No baile, a banda alterna estilos musicais, ora mais agitados, ora mais lentos. Os aldeões têm grande preferência pela música pimba ${ }^{186}$ que, na verdade, é dançada por todos. O momento de maior frenesi, no entanto, se dá quando o grupo musical decide fazer uso da concertina para executar durante algum tempo ritmos considerados tradicionais, típicos dos ranchos folclóricos. Um grupo grande dança intensamente ao ritmo da música. São quase todos emigrantes, entre eles Laura, Mariana, Dênis, Aloísio e seus dois filhos. Esse grupo, radicado na França, tem grande desenvoltura nessa espécie de dança porque frequenta na França as Casas de Cultura, onde os passos são ensinados e ensaiados para apresentações ao longo do ano. Erguem os braços na altura dos ombros e colocam os antebraços para cima, dobrados em "L", realizando rápidos rodopios sincronizados com movimentos das pernas e batidas com as solas dos pés. Trocam constantemente de direção e sincronizam seus paços, interagindo durante a dança de modo bastante harmônico. Por vezes dançavam livremente demonstrando grande habilidade movendo muito rapidamente os pés, cruzando as pernas e batendo o solado dos calçados. A certa altura, próxima do encerramento da festa, o grupo musical repetiu as músicas folclóricas a pedido dos emigrantes que haviam dançado de modo tão animado anteriormente. O baile estava em parte esvaziado, mas ainda havia um grupo considerável de pessoas que queria aproveitar a comemoração até o último instante. $\mathrm{O}$ entusiasmo com a música nesse instante foi tão grande que muitos subiram ao palco, principalmente as crianças e adolescentes, e dançaram ao lado dos músicos.

Dessa forma, podemos considerar que no baile do dia quatorze ocorre a comunhão festiva de modo mais efervescente entre emigrantes e aldeões. Essa comunhão ocorre também no contexto da procissão do dia quinze, mas com outras características. A distinção entre as celebrações dos dias quatorze quinze é importante para notarmos

\footnotetext{
186 A música pimba é, em grande medida, produzida para o contingente emigrante. São diversas as canções pautadas pelas festividades de verão e pela experiência migratória e os sentimentos a ela associados: saudades, nostalgia, etc. Um exemplo é o clássico “O Emigrante”, tantas vezes regravado, com o seguinte refrão: "Longe da terra, distante. Longe do seu Portugal. Vivendo como emigrante, longe da terra natal”. Disponível no link: http://www.youtube.com/watch?v=Q-lmYHaYSEc (acessado pela última vez em 24/09/2013).
} 
que, embora o tempo festivo reúna emigrantes e residentes, em alguns aspectos fica claro que eles vivem temporalidades diferentes.

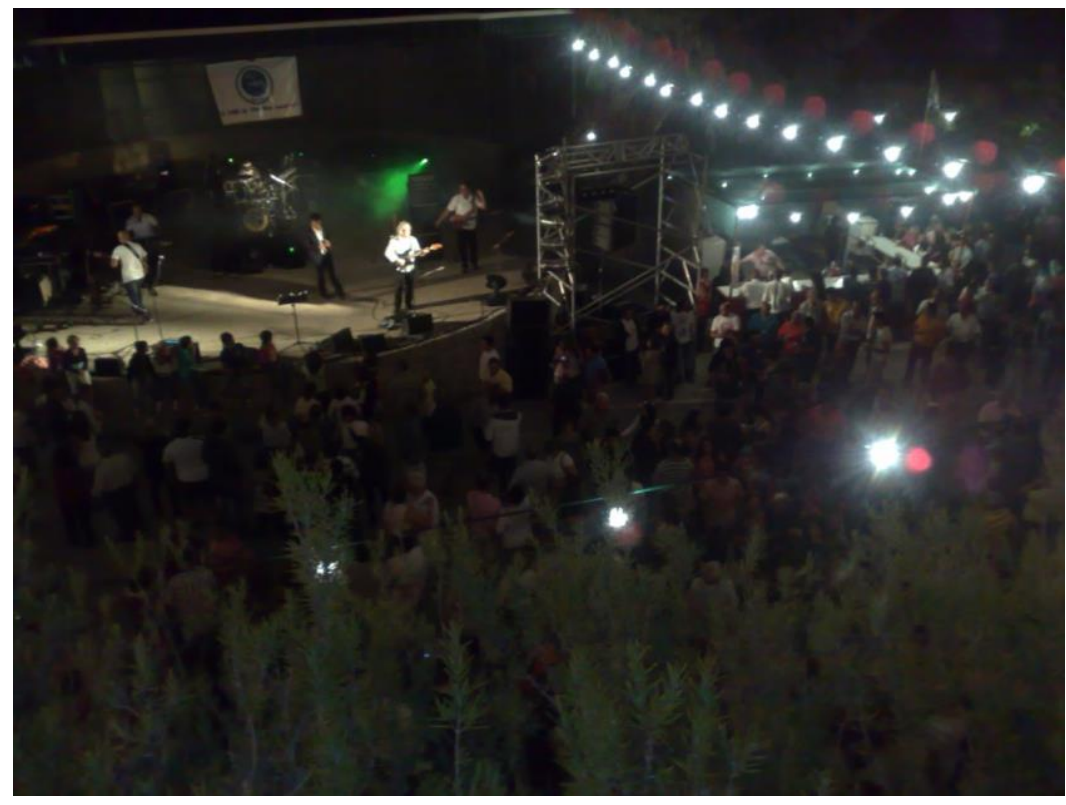

Figura 8. Baile da festa do dia quatorze de agosto.

É importante ter sempre em conta que, para o emigrante, a temporalidade festiva corresponde a todo o tempo de férias que se passa no concelho. Isso faz com que o baile do dia quinze, posterior à procissão, tenha uma presença acentuadamente marcada pelos emigrantes, com participação muito menor por parte dos aldeões. João, por exemplo, assim como a maioria dos demais aldeões, não pode tirar férias nesse período do ano. Muito pelo contrário. Como trabalha na coleta do lixo, seu trabalho redobra e as horas extras se multiplicam. Nas palavras dele, a presença dos emigrantes no baile do dia quinze se dá porque "os emigrantes não têm que trabalhar no dia seguinte, podem dormir até quando queiram". A tensão antes observada nas interações no Café então se reproduz de modo similar em outros âmbitos.

Como característica própria das celebrações do dia quatorze, resta ainda dizer que é também mais longa. Avança madrugada adentro e termina por volta das três horas, enquanto o baile do dia quinze se encerra por volta da meia-noite. Toda a intensidade comemorativa concentrada no dia quatorze é expressa em diversos aspectos profanos de entretenimento. Os jogos marcam sua presença na festa, sobretudo a rifa, em que o 
sorteio aleatório de um pedacinho de papel equivale a um brinde. Os brindes, por sua vez, são objetos usados recolhidos entre os aldeões algumas semanas antes.

Contudo, se a véspera do cortejo é dia de "ir ao fado", como gosta de se referir Zeca, o feriado de quinze de agosto é devotado à fé. A seguir busco pensar o contexto do cortejo processional em honra a Nossa Senhora da Assunção, procurando descrever o quadro complexo de imagens e referências que ele mobiliza, bem como os quadros de interação que ocasiona.

O quinze de agosto

O dia quinze é, dos dias de comemoração, o mais religioso e, portanto, é foco de parte significativa da observação, da descrição. As atividades preparatórias começam cedo. Desde por volta das $8 \mathrm{~h} 30$ as fanfarras acompanhantes da procissão percorrem a aldeia, devidamente trajadas com seus uniformes, anunciando com música a abertura da programação. Uma delas traz também bonecos que animam a aldeia antes da procissão, característicos dessas festas populares. São chamados de "cabeçudos" porque são muito altos, manuseados por alguns dos integrantes da fanfarra que os vestem e manipulam por meio da estrutura metálica que os sustenta internamente. Esses bonecos representam homens, mulheres e crianças em trajes festivos, com roupagem muito colorida, e são, de certo modo, cômicos. Muitas pessoas riem do modo desajeitado como se movem e de suas expressões exageradas: sorrisos imensos, maquiagem gritante e cabeças enormes, desproporcionais.

As fanfarras se sucedem em intervalos programados até o começo da tarde. Pela manhã são realizadas confissões com o pároco, de modo que é reservado um horário a partir do meio-dia para confissão dos peregrinos recebidos. A aldeia se agita para os eventos que se seguirão na parte da tarde e é tomada por uma quantidade excepcional de pessoas, entre ônibus de peregrinação, visitantes das aldeias vizinhas, vilas e cidades próximas, estrangeiros turistas, e mesmo emigrantes chegados de última hora.

Das 14h em diante as pessoas começam a dirigir-se para o pavilhão onde já se encontram montados os andores, à espera do começo da grande procissão. Uma imensa 
aglomeração começa a se formar. O pavilhão que guarda os andores é como um enorme galpão e fica no princípio do caminho para o Talef, em um ponto da aldeia praticamente oposto ao Cabeço. Por dentro é alto e amplo o bastante para que caibam os onze andores com alguma folga. Há também um cômodo pequeno em seu interior, feito com paredes baixas, improvisado como vestiário, para que as pessoas possam colocar os trajes da personagem que encenarão na procissão.

A concentração de pessoas no fundo da aldeia cresce conforme se aproxima a hora da procissão. As que não aguardam no interior do próprio pavilhão, acomodam-se nas proximidades, abrigadas do sol sob as poucas árvores daquele pedaço. Sentam-se nos degraus do cruzeirinho situado na esquina ao lado da escola primária, ou ainda nos baixos muros da escola. Há muitos que aguardam mesmo sob o sol, esperando em frente à porta do pavilhão pela tensa e complicada saída de alguns andores para a rua (devido ao peso e tamanho dos maiores andores, erguê-los e tirá-los do pavilhão é uma difícil tarefa que exige força e precisão para que possam passar pelo portão sem se chocarem com as paredes, evitando que se quebrem ou danifiquem).

Os músicos da fanfarra também aguardam e escondem-se como podem do calor, já que a procissão será longa e inteiramente realizada sob o forte sol da tarde. Quando são por volta das $15 \mathrm{~h} 45$ uma das fanfarras adentra o pavilhão em formação e executa uma performance vigorosa que prepara os ânimos para a chegada da imagem de Nossa Senhora, trazida da igreja no interior da aldeia para o pavilhão. O som poderoso dos bumbos ecoa no ambiente e retumba.

Às 16h parte um cortejo da igreja de Santa Maria Madalena (onde estava a aguardada imagem da santa) desde já acompanhado por um grupo significativo de pessoas e pela Banda de Música da Portela, conjunto musical diferente das fanfarras, que cumpre outra função na composição do cortejo, responsável por acompanhar a santa em tom de absoluta solenidade e gravidade, executando instrumentos de sopro como flautas e trompetes. À sua frente, três senhores, trajados com capas vermelhas de camurça levam um crucifixo de metal bastante alto e dois estandartes com a heráldica de Nossa Senhora da Assunção. Logo atrás segue a cúpula que leva a santa, que a abriga e envolve e que será, muito em breve, assim que chegue ao pavilhão, acoplada na parte superior do restante do andor. É carregada por seis homens em um tipo de pequeno andor até o pavilhão em que aguardam os demais andores, onde é imediatamente recebido com 
aplausos e o vigor da música das fanfarras, no ato de "saudação a Nossa Senhora". Junto à santa carregada, exatamente atrás, vão o pároco local e o bispo, cobertos por um tipo de tenda carregada por quatro pessoas, cada uma das quais sustenta uma haste que, por sua vez, ampara um tecido que produz sombra para aqueles que serão os responsáveis por conduzir as preces durante a procissão.

No pavilhão, junto a cada andor posicionam-se aqueles que irão carregá-los, preparando-se para erguê-los, ladeados por familiares que geralmente se dispõem a ajudar levando, além de garrafas d'água, os apoios utilizados para sustentar os andores nas pausas previstas ou em algum eventual momento de fraqueza. As pessoas ou grupos interessados em participar carregando algum dos andores chegam com bastante antecedência já que aqueles que se encarregam dessa tarefa devem ter o nome inscrito em uma ficha afixada em cada andor. Por esse motivo desenvolvem-se, em algumas situações, pequenos conflitos e tensões entre os que desejam abraçar algum andor específico, por algum motivo de promessa ou devoção ${ }^{187}$.

Uma proximidade orgânica entre aldeões e santos de devoção é vivida como constitutiva dos modos de construção do pertencimento. Desse modo é fundamental refletir sobre uma série de trocas que são operadas nesse contexto. Procuro, por meio desses elementos, pensar a agência do sagrado e as trocas operadas entre fiéis e divindades constitutivas de uma espécie de "sistema de prestações" (MAUSS, 2003: 191), em que são oferecidas devoção, orações e promessas, e esperada a comiseração do sagrado. Quando uma família se encarrega do transporte de determinado andor isso implica em grande parte dos casos uma devoção continuada e uma relação íntima de troca com o santo com a expectativa de obter proteção e de ajudas variadas (trabalho, saúde, etc.).

187 Aloísio havia comentado algumas vezes que há muitos anos se compromete a carregar o andor de Santo Antônio. Na primeira ocasião em que acompanhei a festa pude observar seu empenho. Na segunda ocasião em que realizei trabalho de campo, no entanto, ele não pôde carregá-lo. As inscrições foram preenchidas antes que ele pudesse se inscrever. Ele quis ainda argumentar com a organização do evento, quis apelar, mas não houve modo de resolver, os organizadores foram impassíveis. Aloísio se indignou e esbravejou, reclamando do fato de o número de carregadores do andor ter sido reduzido de seis para apenas quatro. Por fim, tentou ainda argumentar com algumas das pessoas que haviam conseguido se inscrever, mas ninguém aceitou ceder sua vaga. Ao longo de todo o trajeto ele subiu a procissão ao lado do andor, aguardando a possibilidade de revezar com algum dos carregadores inscritos. 
Toda essa economia de trocas simbólicas tem, em grande parte, relação com as angústias que se interpõem ao processo migratório. Espécie de ancoradouro espiritual, a devoção religiosa é uma força motriz importante para as iniciativas e a retroalimentação dos projetos migratórios. Também por isso é comum que algumas pessoas constituam uma tradição propriamente familiar, propondo-se a anualmente repetir a promessa de carregar determinado andor até o adro do santuário, onde todo o aparato processional permanecerá guardado por algum tempo após o término da festa. É o caso, por exemplo, da família das irmãs Francisca e Rosa. Seus maridos, ajudados por familiares e amigos, levam já há alguns anos o andor de Santa Eufémia. O núcleo familiar de Francisca vive na aldeia e Pedro, seu marido, trabalha na pedreira da região. Já o núcleo familiar de Rosa vive em Bordeaux, no sul da França. Ela trabalha como faxineira e Ronaldo, seu esposo, como maçon ${ }^{188}$, na construção civil. Segundo eles, esperam apenas que a santa os ajude a ter sempre boa viagem e a encontrarem-se no ano seguinte ${ }^{189}$. Trata-se portanto de uma relação duradoura em que a fidelidade devocional, a repetição anual de um ritual penoso, dimensão sacrificial da festa, reforça o vínculo entre homens e santos ${ }^{190}$.

Após a ovação do público e a saudação das fanfarras inicia-se um dos momentos mais tensos do início da procissão: a santa precisa ser erguida até o topo da enorme base do andor que a espera no pavilhão. Muitos homens soerguem a base para que o andor seja retirado do suporte em que se encontra e que o torna ainda mais alto. Colocada inicialmente ao rés do chão, a santa em sua cúpula precisa ser levantada com cuidado e acoplada ao topo da parte inferior do andor. O manto da cúpula é retirado e muitas ma-

188 Como já dito, maçon é o termo francês (geralmente utilizado pelos emigrantes) para se referir à profissão de "pedreiro". Em Portugal, um pedreiro é mais comumente denominado como trolha.

189 É importante ter em consideração que as promessas comumente envolvem uma dimensão de segredo. Nesse sentido, inquirir alguém sobre suas promessas a alguma santidade é algo bastante complicado. Algumas vezes desisti de fazer essa pergunta e, quando a fiz, recebi respostas tímidas, que por vezes procuravam se desviar do assunto.

$190 \quad$ Na segunda vez em que observei o cortejo dos andores, Ronaldo estava com o joelho enfaixado. Ele havia se acidentado no trabalho na França e antes de ir para Portugal tinha ficado um período afastado. Antes do cortejo cogitou seriamente não carregar o andor naquele ano. No final das contas carregou acompanhado de seus cunhados e outros parentes. Um deles decidiu carregar o andor pela primeira vez nessa ocasião, apenas com o intuito de auxiliar Ronaldo. 
neiras de elevar a santa ao topo do andor são cogitadas, ensaiadas, até que se decida como a tarefa deverá ser executada.

Presenciei em uma das vezes que pude observar a preparação da saída processional uma tentativa malsucedida, em que os carregadores tiveram que baixar novamente a santa para que não caísse. A inclinação que tomou a estatueta assustou a muitos. $\mathrm{O}$ padre, que organizava todo esse processo na ocasião observada, pediu, alterado e nervoso, que as pessoas se afastassem e dessem espaço para que conseguissem acoplar a santa como se devia. Por alguns instantes as pessoas temeram algum acidente com a imagem cultuada. Qualquer erro poderia significar o fim da procissão antes mesmo que ela começasse. Na segunda tentativa a santa foi erguida pelas hastes da cúpula enquanto era amparada pelos lados para que não virasse. Foi, afinal, acoplada.

Concluído todo o processo preparatório, inicia-se então o cortejo processional com a própria fanfarra que marcha para a rua e avança algumas centenas de metros. Para, então, em formação, à espera do restante da procissão. Na sequência, seguem-na a cruz paroquial e os estandartes, os mesmos que acompanharam a santa da igreja para o pavilhão. Em seguida saem os andores numa sequência determinada, e parece que também em ordem de tamanho, de modo que o último a deixar o local é o de Nossa Senhora da Assunção. Os andores organizam-se em uma sequência crescente, como que em ordem de tamanho e de quantidade de ornamentos. O andor de Nossa Senhora, por sua vez, não é de modo algum o mais alto, mas é o mais suntuoso, ornado com formas barrocas pintadas de dourado e também, muito provavelmente o mais pesado. Sem dúvida alguma, é o mais disputado, carregado por um número maior de pessoas.

Andor após andor, estandarte após estandarte deixam o galpão que os guarda numa sequência absoluta e naturalmente lógica para todos que estão intimamente familiarizados com a procissão da Senhora da Assunção de Vilas Boas. Com cores e tamanhos que denotam uma hierarquia do sagrado, toda a variedade de santidades cultuadas de modo específico pela aldeia segue representada e simbolizada no ato processional. A simbologia devidamente respeitada se relaciona à particularidade de cada santo. Plêiade de santidades que demandam devoção extrema durante a homenagem, relação duradoura que se perpetua entre fiéis penitentes e divindades celebradas.

O grupo que avança pelo caminho na dianteira é composto por oito andores. $\mathrm{O}$ primeiro deles é o do "Menino Jesus", pequeno, carregado por quatro crianças por vez 
recém-iniciadas pelo ritual da primeira comunhão (em missa ocorrida na manhã do dia anterior). Logo saem também, em sequência invariável, os andores de Santa Inês, São Roque, Santo António, Rainha Santa Isabel, Coração de Jesus, Coração de Maria e Santa Maria Madalena. Cada andor que passava pela porta do pavilhão aumentava a expectativa e a tensão, já que eram cada vez maiores e mais difíceis de manusear. O andor de São Roque gerou imenso burburinho porque precisou ser inclinado demasiadamente para sair e esteve a ponto de cair. Intercalados aos andores seguem ainda grupos de pessoas representando figuras bíblicas e outras figuras cristãs, tais como apóstolos, anjos, santos e santas.

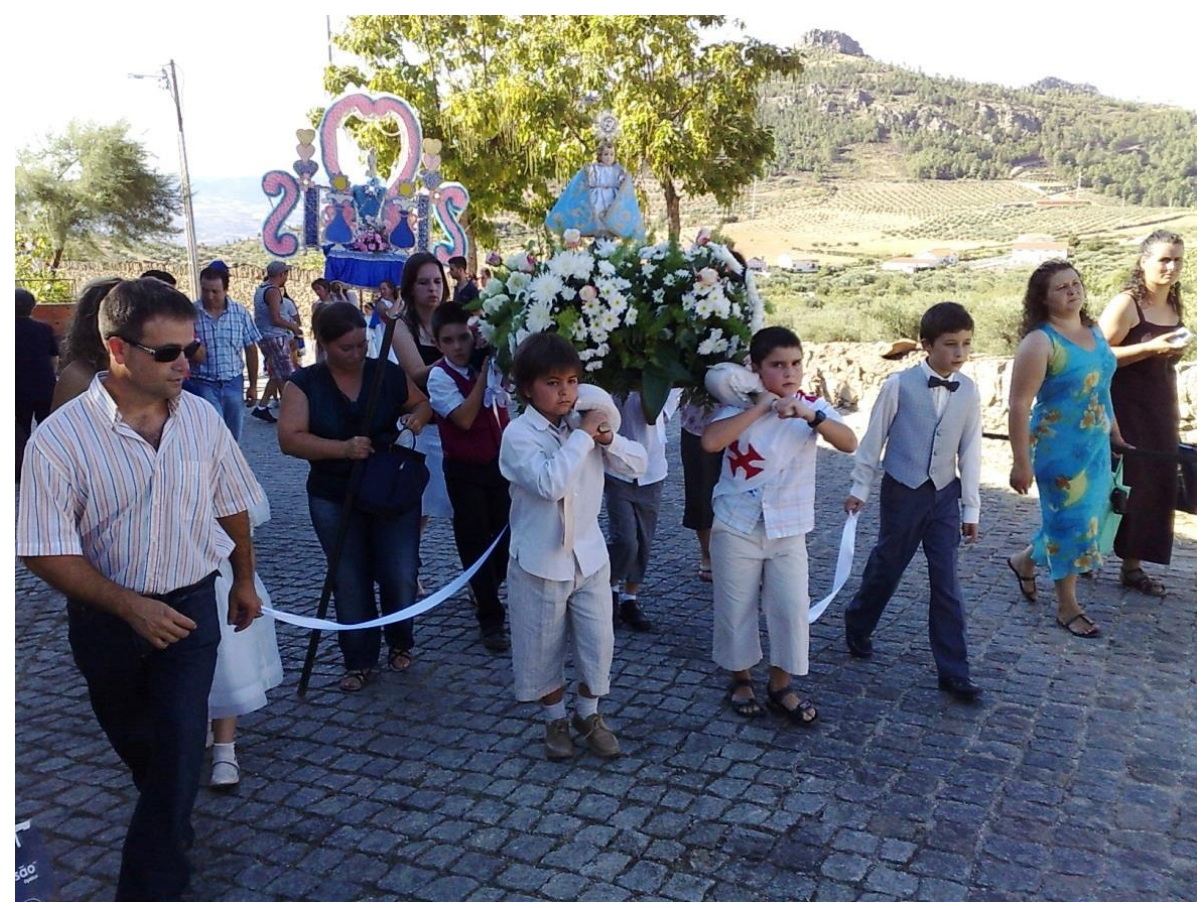

Figura 9. Andor do "Menino Jesus", primeiro do cortejo, carregado exclusivamente por crianças.

Após o primeiro grupo de andores segue a Banda Marcial de Murça em marcha. Intercalando-se aos demais andores seguem também a Fanfarra de Lever, bem como o Grupo de Bumbos de Santo André trajado em cores laranja e verde muito vivas. Imediatamente depois saem do pavilhão os andores da Ascensão do Senhor e o de Santa Eufémia, o segundo grupo. O de Santa Eufémia é, sem dúvida, o mais alto. Ao chegar à porta do pavilhão, seu tamanho fez com que algumas pessoas à minha volta acreditassem e dissessem que não passaria. De fato, quase se chocou na parte superior. Os andores são, 
em geral, feitos de material bastante frágil. Qualquer pancada os faria quebrar. Foi, portanto, um momento de grande apreensão, marcado pelo acúmulo de tensões que as expectativas em torno da procissão ocasionam. Os homens que o carregavam dobraram os joelhos ao máximo que puderam e ainda assim o andor não passou, pendendo para os lados de modo arriscado, até que um dos organizadores da comissão de festas da aldeia sugeriu que a parte de trás fosse colocada completamente no chão para que o andor pudesse ser inclinado para trás e puxado pela frente até que fosse possível passar sem ter que encostar na parte de superior do portão do pavilhão.

O momento de início da procissão é delicado porque coloca em jogo os interesses de diversos agentes que se articularam durante a preparação do evento e concentra as diversas expectativas que cercam a realização do cortejo, acumuladas no decorrer do ano que separa a procissão passada da ocasião presente. Os esforços convergem para que a realização do evento satisfaça de modo geral as pretensões à sua volta: a Igreja prima pelo sucesso do culto, os fieis se esforçam para cumprir suas promessas (seja contribuindo com o transporte dos andores, seja de alguma outra forma), a classe política local busca ampliar sua visibilidade e agenciar a festa ${ }^{191}$, etc.

191 Cabe apontar brevemente que a classe política aproveita a ocasião que aglutina de modo excepcional o contingente migrante e o grupo residente para conquistar aprovação e apoio político. Isso se torna etnograficamente visível não apenas quando são criadas ocasiões para divulgar as políticas e eventos promovidos pelos membros da gestão vigente (tal como a supracitada exposição fotográfica sobre a comemoração promovida no início daquele ano, em homenagem aos quinhentos anos da carta foral concedida a Vilas Boas, que emancipou política e administrativamente a aldeia), mas no modo como as lideranças políticas procuram acompanhar a procissão e se aproximar das lideranças religiosas nessa ocasião específica. Ademais, parte dos emigrantes manifestou pontualmente algum interesse pela gestão política local. Não pude observar os momentos de disputa e campanha eleitoral, mas esse tema apareceu marginalmente. Alguns poucos emigrantes revelaram ainda se envolver de algum modo com as disputas de cargos administrativos locais. Damião, por exemplo, manifestou esporadicamente seu apoio ao grupo político da atual gestão (constituído fundamentalmente por membros da família proprietária do Café de cima) e disse que pretendia voltar à aldeia meses depois para expressar seu voto nas eleições para a presidência da Junta de Freguesia. 


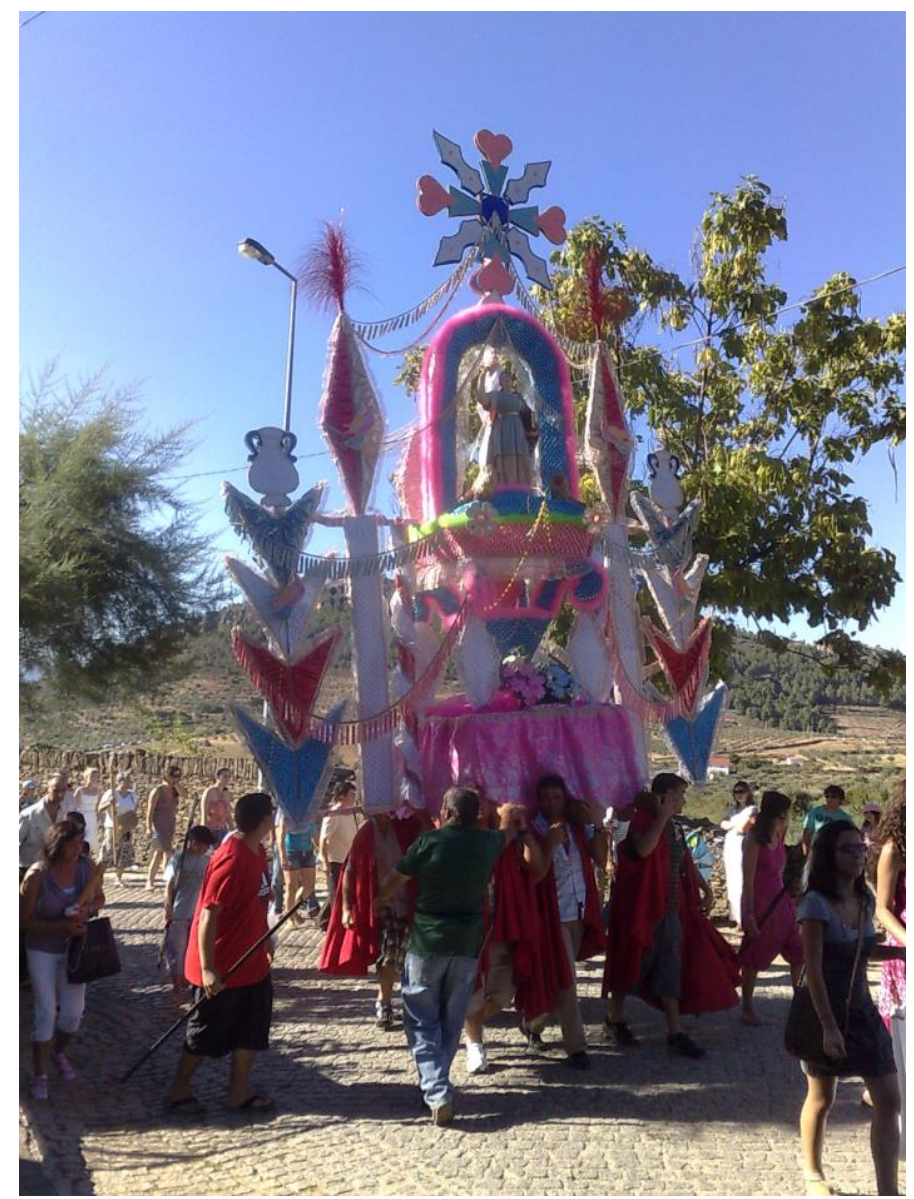

Figura 10. Andor de Santa Eufémia

Logo após esse segundo bloco seguem, em duas filas paralelas, as pessoas que buscam pagar promessas. A fila da esquerda é composta por aquelas que, por diferentes motivos, percorrerão descalças o caminho todo da procissão. Já a fila da direita é formada pelas que seguem calçadas, mas procuram pagar promessas de outras maneiras. A maioria leva nas mãos uma grande peça de cera ou vela que se relaciona de alguma forma com suas respectivas promessas: pernas, seios, braços, cabeças, crianças ou mesmo grandes bastões de cera são carregados. 


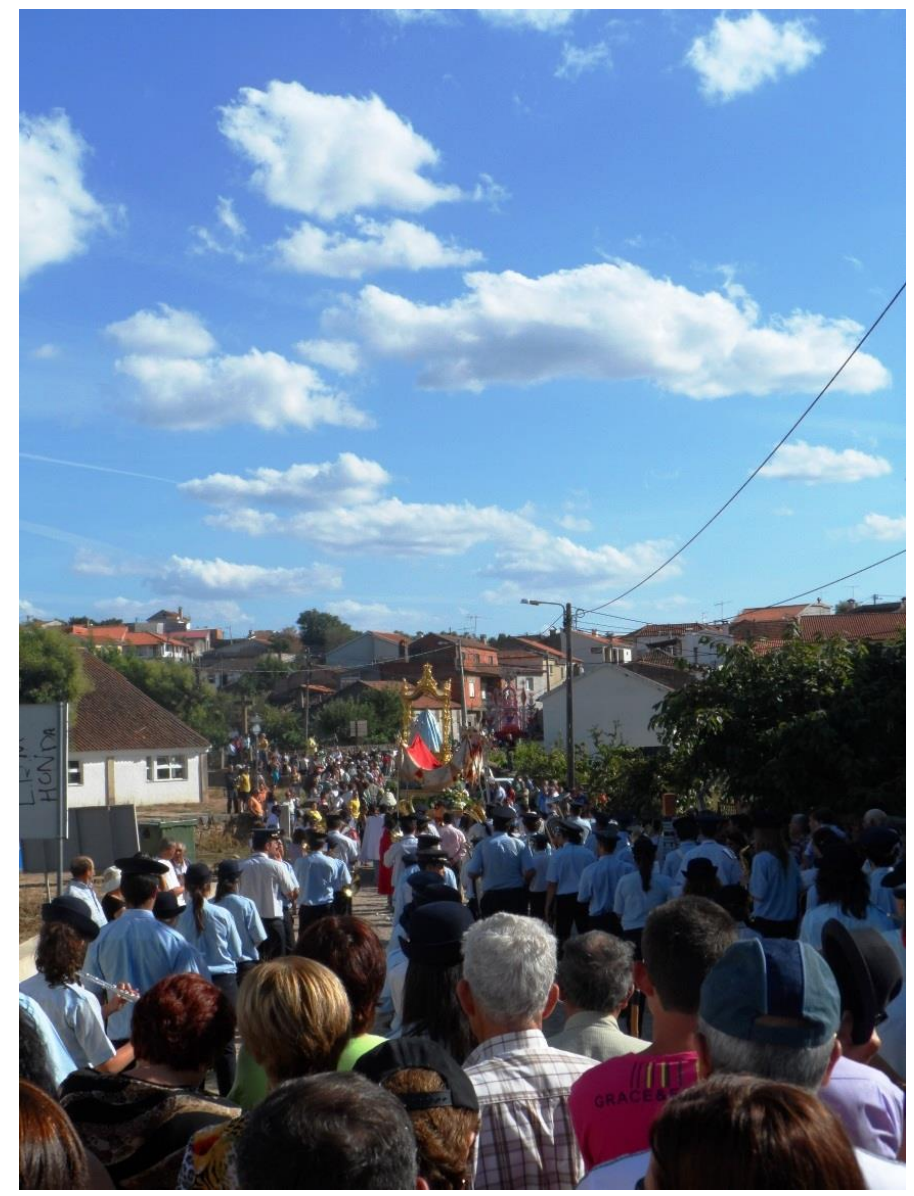

Figura 11. Cortejo se formando logo após a saída do pavilhão.

Há, portanto, uma forma local de vivência da religiosidade e que exprime de modo completo suas características no contexto do cortejo do dia quinze de agosto. Dessa forma, a noção de "religião popular portuguesa" ${ }^{192}$ se refere a esse modo subjetivo dos grupos locais de relação com suas festividades e com o sagrado. Segundo definição de Moisés Espírito Santo, "religião popular" é aquela que

"goza de certa autonomia em relação à instituição eclesiástica, ainda que ambas tenham traços comuns e estejam por vezes ligadas. (...) Ela liga-se, sim, a um tipo de cultura que se transmite nas relações de vizinhança e na memória colectiva. (...) A religião popular é espontânea, de criação colectiva e pertence ao fundo cultural da comunidade" (1990: 17)

192 O autor usa como referência a ideia de "religião aberta", de Roger Bastide (2006, [1975]). 
O andor de Nossa Senhora é então trazido até a porta do pavilhão onde lhe é feita uma última saudação quando, finalmente, por volta das $17 \mathrm{~h} 30$, é erguido e segue em procissão, seguido pela multidão. Mais do que a música tocada em momentos demarcados do cortejo, os intervalos de profundo silêncio contribuem para o tom solene da marcha da procissão. Somente a oração, puxada pelo padre em um megafone, corta o silêncio meditativo. O silêncio das pausas é o contraponto das orações repetidas pelo coro da multidão que acompanha e ecoa a voz do padre que dita as preces, auxiliado por um par de alto-falantes. A repetição exaustiva das orações, em ladainha, auxilia a produção de uma catarse de fé, de compenetração nos propósitos religiosos.

No começo da tarde a grande procissão toma seu lugar. O percurso que atravessa o miolo da aldeia tem o propósito figurado de envolver toda a área da comunidade no evento que se quer um fato total, englobante. A lentidão do andar da procissão, suas pausas previstas e estratégicas, seus estandartes e andores produzem sua visibilidade enquanto convidam a comunidade toda a integrar-se no corpo do ritual. Os mais velhos, já sem condições de acompanhar a pé toda a extensão do percurso sob o sol escaldante do agosto português, observam pelas janelas de suas casas, emocionados e comovidos pelo auto de fé ali encenado. Acompanham com os olhos o máximo que podem. Muitos ainda se arriscam a subir e acompanhar a missa campal que agora ocorre no novo pátio do santuário, maior e mais amplo (antes a missa de encerramento ocorria defronte da igreja do santuário, no ponto máximo do monte). O trajeto que se inicia no fundo da aldeia (que em termos espaciais demarca o ponto habitado mais afastado em relação ao santuário) corta a aldeia com solenidade.

O caminho é longo e segue primeiro pelo meio do povoado da aldeia. Muitas pessoas juntam-se à procissão nesse momento. Outras apenas esperam por ela para saudá-la. Acenam com panos pendurados nas janelas para indicar a saudação. Ao sair do povoado o caminho torna-se cada vez mais íngreme. A procissão, quando sobe a Rua do Areal começa a "sair" da aldeia. As casas nessa parte da aldeia são mais recentes, feitas sobretudo após a década de $1980{ }^{193}$. Situam-se acima do cemitério, antigo marco limí-

\footnotetext{
193 Momento em que o grande número de retornados demanda novas construções. Retornado é o modo pelo qual ficaram conhecidas as pessoas obrigadas voltar para Portugal após a independência das
} 
trofe da aldeia em sua parte mais alta e constituem como que um novo bairro que, por situar-se fora do centro histórico da aldeia e ter maior disponibilidade de terrenos, tem sido preferido pelos emigrantes para a construção de novas casas.

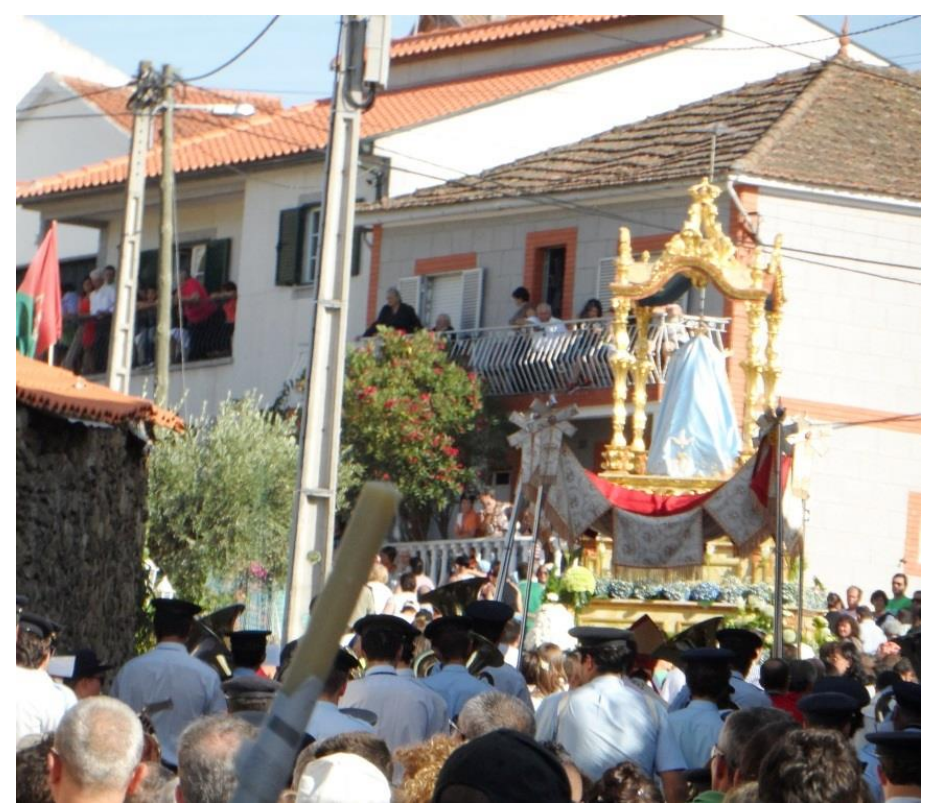

Figura 12. Visualização do andor de Nossa Senhora da Assunção cruzando a aldeia.

O cortejo segue até o cruzamento que bifurca entre o caminho do santuário e a estrada que leva a Vila Flor. A procissão segue pelo caminho de paralelepípedos acima, em direção ao topo do monte. Há gente por todo o caminho, nas margens, observando. Algumas interações se dão nesse ponto do caminho, sobretudo nas bordas do cortejo, pontos mais afastados dos andores, onde mal se consegue ouvir a voz do padre emitida pelos alto-falantes. Emergem breves interações de caráter variado, comentários curtos feitos em voz baixa, em respeito à concentração dos caminhantes que rezam. Numa dessas interações breves, João conversava com um aldeão vizinho seu, o senhor Almir, quando um emigrante amigo de ambos se integrou à conversa. Com um intenso ar jocoso, o diálogo se desenrolou da seguinte maneira:

colônias africanas. Parte dessas pessoas retornou para as aldeias onde viviam antes de terem se deslocado para a África. 
João: - E então, ficas aqui parado? Quem é que leva os andores? Eles não sobem sozinhos ao santuário!

Emigrante: - Pois não! Levai-os vós!

Sr. Almir: - Olha, nós cá estamos todo o tempo. Vós que cá só aparecem uma vez por ano é que tinham que carregá-los, que era para ver se faziam algo pela aldeia!

Aqui mais uma vez a tensão entre emigrantes e residentes se revela de modo tácito, mesmo em uma situação de intenso júbilo coletivo e interações jocosas, em que por meio de brincadeiras os significados são colocados em jogo. Essa tensão, portanto, permeia todos os espaços de grande interação no período da festa.

Conforme a procissão avança, logo alcança os estacionamentos improvisados nos terrenos laterais ao caminho. É possível vê-los completamente lotados de veículos, entre os quais os ônibus que trouxeram as caravanas de romeiros. Não muito longe é possível enxergar uma coluna de fumaça escura, que indica mais um foco de incêndio, comum nesse período de intenso calor e seca. Dali em diante o caminho segue cada vez mais íngreme pela estrada que leva ao santuário, já erma, sem maiores concentrações de habitações no entorno, de onde se passa a avistar espaços de plantio. O percurso seguido é atualmente todo revestido de paralelepípedos de pedra talhada. No passado, o percurso era feito por uma rota no meio da floresta de pinheiros que reveste o monte do Cabeço ${ }^{194}$. De certo ponto observa-se que o cortejo colocado em curso adquire uma extensão destacável. Enquanto o fundo do cortejo ainda contornava a curva para começar a enfrentar a inclinação do monte, a ponta do cortejo era saudada pelos sinos do santuário por ter chegado ao ponto esperado.

194 O museu do santuário é repleto de fotos que ilustram os antigos percursos e as construções das vias de passagem no monte. 


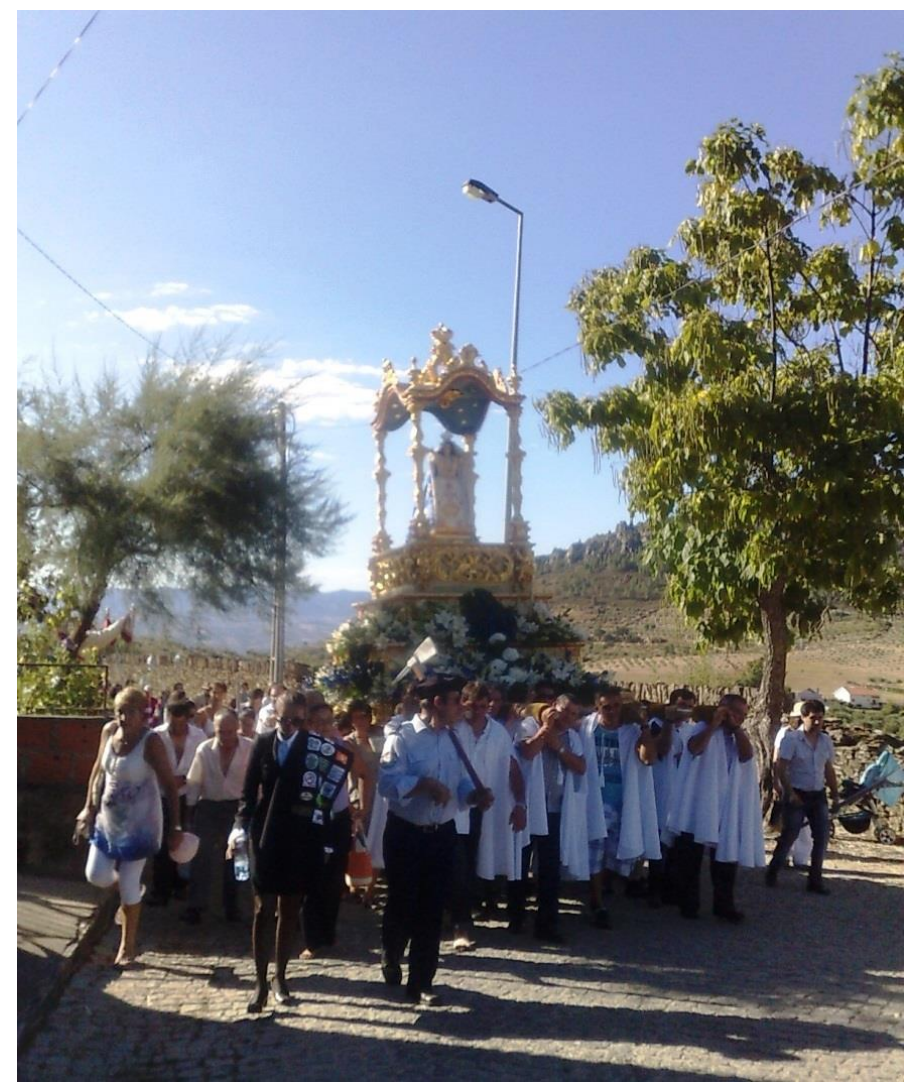

Figura 13. Andor de Nossa Senhora da Assunção visto quando começa a sair do povoado e se aproxima Cabeço para ser carregado até o topo do monte.

A certa altura do trajeto cruza-se a feira de diversidades que se instala habitualmente sempre no mesmo ponto da ladeira processional. A agitação comum desse espaço, a aglomeração caótica de pessoas, a sobreposição de sons, bem como a prática profana do comércio são suspensas durante o ato religioso de travessia. Tais práticas cedem momentaneamente lugar ao tempo regrado da procissão, à sucessão prescrita de procedimentos sagrados, religiosos, à gravidade do pagamento de promessas, à ordenação clara de posições da estrutura processional. A festa assim se estrutura segundo uma sucessão alternada de momentos do sagrado e do profano. Sem interposições de temporalidade que agridam sua forma esperada, a festa se faz segundo essa oposição respeitada e tensa entre o tempo da procissão e o do festejo propriamente dito.

A totalidade do trajeto se completa no cume do monte sagrado e só se encerra de fato com a chegada triunfante do centro das atenções, a imagem da Senhora da Assunção. Imponente, a cor dourada predominante em seu andor é símbolo da centralidade 
que ocupa nas representações sagradas da festa. Tudo isso atrai as atenções, direciona os olhares à homenageada pelo culto ritual,

\begin{abstract}
“a que se erguerá no pedestal estável, deixará o recinto fechado e reservado e, levada aos ombros, animada pelo ritmo da marcha, percorrerá, entre as casas, os caminhos da vida cotidiana dos homens para a erguer ao plano da eternidade. É então que a imagem alcança a plenitude da sua presença funcional. Comunica e faz comunicar. Entra em jogo - no jogo de uma teatralização eficaz - e por meio dela o santo renova e intensifica o contato que a sua presença no santuário tornava simbolicamente mais distante" (SANCHIS, 1983: 44)
\end{abstract}

Os adornos barroquizados trazem ainda uma infinidade de detalhes que reconstituem com minúcia uma estética verificável também no altar do santuário. Poder carregá-lo é uma honraria simbólica tamanha que os espaços sob o andor são concorridos, até porque são raros os revezamentos durante o percurso. A chegada do andor-maior, que fecha a procissão, é o momento a partir do qual se começa a organizar a celebração da missa excepcional, já que a missa dominical no decorrer do ano é celebrada regularmente na igreja de Santa Maria Madalena, que fica no seio da aldeia ${ }^{195}$.

No cimo, à chegada, o andor de Nossa Senhora fica no pátio novo, ao lado de um pequeno palco improvisado como altar, porque será rezada ainda uma missa, isso quando já é por volta das $19 \mathrm{~h}$. Os demais andores, no entanto, são levados até o topo do monte e são deixados ao lado do santuário, em frente à loja de artigos religiosos. Esse é o momento em que a Casa dos Milagres está mais disputada. A multidão se dispersa pelo espaço aberto. Muitas pessoas sentam-se pelo caminho e ocupam as escadarias do santuário para descansar ao final da procissão.

195 Essa é uma das raras ocasiões em que o espaço do santuário é usado em celebrações. Exceto nas festas de agosto, em homenagem à padroeira Nossa Senhora da Assunção, o espaço só é utilizado em casamentos e, algumas vezes, em eventos coletivos de batizado e primeira comunhão, fato que acentua o caráter de excepcionalidade da festa. 
A maioria dos fiéis que acompanham a procissão chega aos poucos, depois do último andor, e vai se acumulando em frente ao palco de onde o padre profere a missa. Alguns procuram a sombra das árvores ao redor. Outros não se incomodam com o sol e aguentam firmes debaixo de seus chapéus. Encerrada com uma grande salva de palmas em homenagem à Senhora da Assunção, o fim da missa campal abre espaço para a festividade que se seguirá. Os aldeões aproveitam o intervalo para a reunião em almoços familiares. Esse momento é também de algum modo ritualístico. Aqueles que almoçam juntos no dia quinze, data máxima da celebração, são os que têm - e naquele instante explicitam - os vínculos sociais mais fortes.

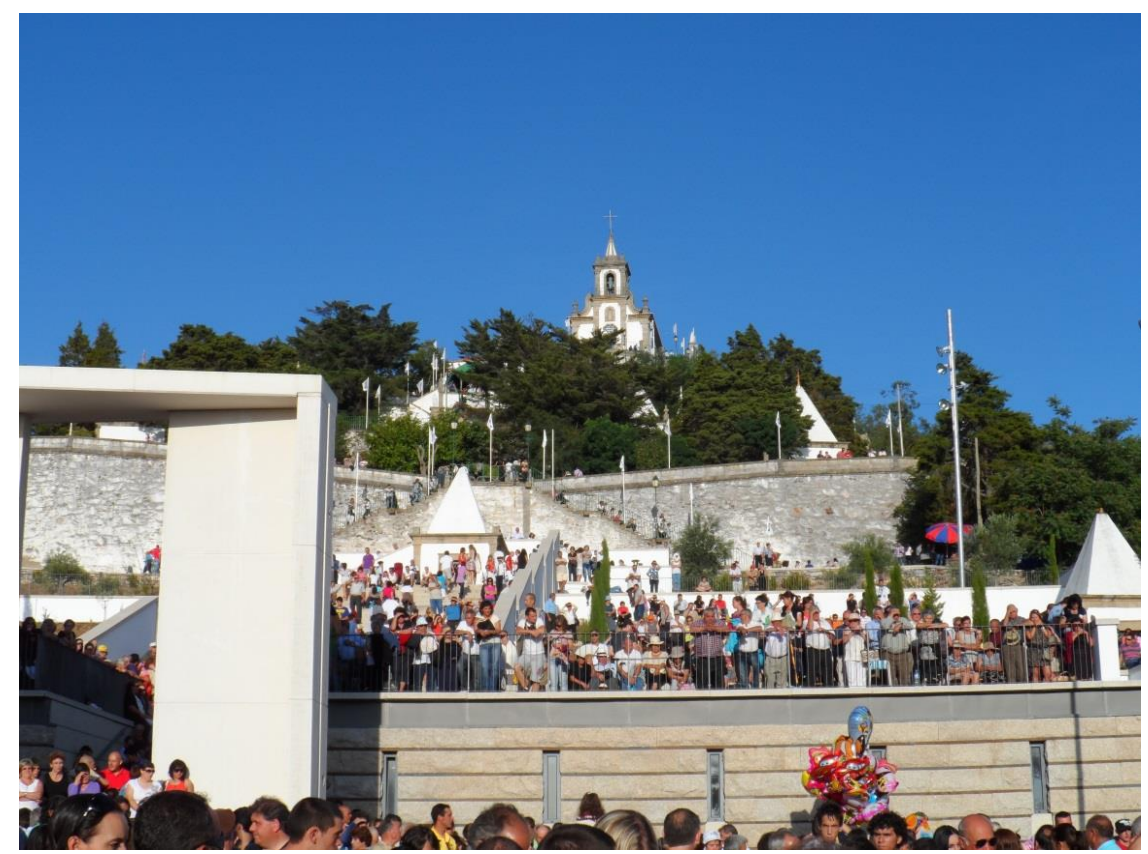

Figura 14. Reunião no novo pátio para missa ao final da procissão.

Ao descer o caminho de volta para a aldeia vi os peregrinos em suas barracas, comendo ao ar livre em mesas de concreto que o santuário deixa à disposição. Mais abaixo, já entrando no miolo da aldeia, era possível ver pessoas reunidas nos quintas das casas assando carnes e jantando em família. Um tipo de sociabilidade generalizada se alastra por todos os espaços: a rua e a casa, o café e a igreja. É tempo de encontro. As 
casas, um tanto mais convidativas, são tomadas por refeições em família tão mais numerosas quanto mais se aproxima o baile ${ }^{196}$.

Após esse ínterim, enquanto o final da tarde é ocupado entre idas à feira da festa e aos cafés, espera-se ansiosamente pelo baile noturno de encerramento da festa. A noite instaura o momento da celebração profana por excelência. O bailarico é animado por toda a decoração luminosa e a frequentação do público, sobretudo emigrantes. Todos se conhecem e reconhecem, e mais uma vez se revelam nessa situação relações de proximidade e distância.

A festa do dia quinze, portanto, pontua o tempo: ápice das comemorações, ele demarca também o momento a partir do qual se inicia o arrefecimento de um tempo quente que vinha sendo celebrado. Esse percurso que liga a aldeia desde o seu recôndito fundo ao cume do sagrado monte, ao santuário, cumpre também a função de reiterar os limites físicos da aldeia e de neles incluir o Santuário que, embora afastado geograficamente e isolado no cimo do outeiro é integrado de maneira orgânica ao corpo da comunidade em festa.

Havia no ar não mais que um burburinho. O silêncio que então parecia reverberar desaparece. A voz solitária do padre irrompe e fala pela última vez sozinha no sermão final, que retoma as histórias dos milagres e exalta a romaria de Vilas Boas. A partir de então se vive a satisfação de ter novamente a imagem reposta em seu santuário, seu lugar devido, e satisfeitos por cumprir com suas obrigações com o sagrado, entregam-se à apreciação derradeira da festa profana, à dança e à música pimba.

196 Rosa e Ronaldo estão construindo uma casa em Portugal próxima à casa dos pais de Ronaldo, na aldeia de Candoso, que é próxima de Vilas Boas, a aproximadamente quinze quilômetros. No entanto, nessa ocasião e em algumas outras, a reunião familiar se deu na casa da irmã de Rosa em Vilas Boas, onde hoje vive também sua mãe. 


\section{PALAVRAS FINAIS}

\section{As despedidas e o fechamento de um ciclo curto}

A aldeia muda visivelmente após a festa. A temporalidade fria do cotidiano volta aos poucos, se reinstala paulatinamente, no ritmo das despedidas dos emigrantes. Como assinala um ditado popular local, lembrado por Rosa no momento de sua despedida novamente rumo à França, "após o quinze de agosto, muda o rosto". A aldeia se esvazia, como havia previsto João tantas vezes, ao destacar as diferenças entre o período de celebração e os demais períodos do ano.

Logo após a grande procissão os emigrantes começam a partir. A maioria, contudo, aguarda o baile noturno. O esvaziamento da aldeia é gradual e vai se processando nos dias que seguem ao festejo. A partir desse momento voltei a circular regularmente pela aldeia, o que foi fundamental para perceber o modo pelo qual se encerra o curto ciclo do retorno e aldeia volta a se constituir sem a presença dos emigrantes. Os pacatos dias em que pude estar na aldeia após as festas contribuíram para observar a reinstauração do cotidiano.

As caminhadas pela aldeia revelaram uma grande quantidade de veículos nas portas das casas com os porta-malas abertos, sendo carregados de bagagem e memórias. Visitei alguns dos agentes que eu sabia que preparavam sua partida para aqueles dias. Deparei-me com Inácio se preparando para a viagem. As despedidas reforçam uma última vez as expectativas de renovação da dinâmica de afastamento e retorno, de manu- 
tenção de laços sociais. Essas expectativas em torno do reencontro começam a se manifestar também porque, a despeito de qualquer tipo de cálculo utilitário, o migrante alimenta o interesse na participação da festa e para ele "é tal o poder revigorante da festa, que é justo dizer que [vive] "na recordação de uma festa e na expectativa de outra"" (PEREZ, 2002: 25). Continuar participando e mesmo incentivando a realização da festa (com contribuições, participações, doações, ou ainda apenas demarcando sua presença) significa para o emigrante requisitar também participação em uma economia simbólica de produção da aldeia, da identidade aldeã. Significa, para quem parte, a possibilidade de amenizar as propriedades disruptivas da emigração e encontrar no seu deslocamento algo que indique continuidade (das relações, dos referenciais).

E se antes da festa o grande número de atividades em que se envolvem os emigrantes dificultava em certa medida as aproximações, a calmaria posterior à festa permitiu que eu realizasse as entrevistas apresentadas no primeiro capítulo, bem como outras formas de diálogos mais prolongados. Antes das festas os aldeões preparam-se para receber os parentes emigrantes que serão, em grande número de casos, seus hóspedes. Compram mais alimento e bebida, preparam os quartos e cômodos para alojarem mais pessoas que de costume, etc. ${ }^{197}$.

Refletindo mais uma vez sobre aspectos da construção da etnografia, é preciso considerar também que diversas ocasiões que contribuíram para as reflexões e análises aqui empreendidas eu só pude observar em virtude da condição específica pela qual me incluo no campo de pesquisa. De certo modo era esperado por diversos agentes que eu correspondesse às expectativas de construção de algumas relações de proximidade e parentesco. E por meio dessas relações é que tive acesso a diversas situações de interação no espaço doméstico e familiar. Participar de determinadas ocasiões de reunião me inseriram em redes de relações que procurei expandir e seguir. Foram algumas refeições, almoços e jantares, ou mesmo situações de lazer no rio ou nas festas populares, o exercício de pesquisa se desenvolveu através dessa construção de um lugar nas redes de relações, mesmo que em grande parte das vezes a partir do parentesco esperado que eu assumisse. Dessa forma, produz-se um tipo de construção da identidade de pesquisador

\footnotetext{
197 Quase todos aos quais pedi uma conversa ou entrevista antes de se desenrolarem as festividades solicitaram-me que deixássemos para depois das festas, quando seus hóspedes tivessem partido e seu cotidiano comum se restabelecido.
} 
entremeada a uma identidade social, tomada de modo relacional a partir das relações por meio das quais me inseri na aldeia. Tal inserção não prejudica ou inviabiliza a pesquisa, mas insere uma singularidade no modo de perspectivar sua produção.

No final das contas, interpõe-se a necessidade de uma vigilância metodológica constante para a produção do estranhamento das práticas e relações, do olhar construído, uma vez que aspectos da subjetividade do pesquisador são contínua e desafiadoramente trazidos ao centro das questões e problemáticas. Não se trata, no entanto, de repelir essa subjetividade para as margens das reflexões, mas sim de ponderar o modo pelo qual ela influi diretamente na estruturação do conhecimento etnográfico. Conforme expressa Judith Okely, "o engajamento do self no trabalho de campo não pode ser naturalmente suprimido, mas sim precisa ser trabalhado de modo auto-consciente" (1992: 9, tradução minha). Mesmo que antes da pesquisa eu nunca tivesse integrado a dinâmica circulatória de afastamentos e retornos de modo direto, ainda que não fosse percebido como migrante ou mesmo como aldeão, eu estava inescapavelmente ligado ao lugar prescrito para o meu pai e minha família na aldeia. A questão é que, de modo geral, o self é parte do que constitui a pesquisa, sobretudo no meu caso, em que o confronto de subjetividades nas interações de pesquisa revelam uma posição no campo, um lugar no arranjo de relações da aldeia não apenas como pesquisador, mas como parte das relações de parentesco que são produzidas a cada ano na ocasião do retorno dos emigrantes.

Nos dias conseguintes à festa e procissão do dia quinze em Vilas Boas ainda se realizam algumas festas no concelho, tais como a de Vila Flor, mas não atraem grande interesse ou participação dos emigrantes que ainda não partiram ou mesmo dos residentes de Vilas Boas. Nenhum outro momento no ano se compara à dimensão de reunião e encontro que os ansiados dias da festa ocasionam para Vilas Boas. No tempo e no espaço da festa de Nossa Senhora da Assunção em Vilas Boas coloca-se em curso um evento de grande capacidade de convergência da ação social. E nisso consiste a dimensão simultaneamente lúdica e coletiva da festa: toda prática, de investimento ou dispêndio, de envolvimento ou comedimento, coloca em marcha um movimento contínuo de convergência sociativa e firma-se, desse modo, como fator de sociação porque "transforma a mera agregação isolada dos indivíduos em determinadas formas de estar com o outro e de ser para o outro que pertencem ao conceito geral de interação" (SIMMEL, 2006: 60, grifos meus). 
A festa como espaço de observação etnográfica contribui de modo cabal com a apreensão da dinâmica circular de deslocamentos do campo social transnacional. Pude notar que nela estão em jogo diversas formas de interação e de práticas. De modo mais amplo, a intensa participação dos emigrantes na vida social da aldeia durante o período festivo faz crer que a festa é, em todos os seus aspectos (lúdico, religioso, etc.), um dos principais motes pelo qual o vínculo do contingente emigrante com a aldeia se reproduz. A simbologia da festa permanece no centro das representações identitárias do emigrante e se renova no contexto da celebração. Não somente a santa e sua imagem, mas a festa e a história local figuram como elementos acionados para definir pertenças ${ }^{198}$, reafirmadas na reiterada participação dos emigrantes na vida social da aldeia.

O contexto do retorno dos emigrantes para a aldeia, contudo, não é marcado apenas pela comemoração e pelas efervescências coletivas. Um número grande de tensões e conflitos subjaz às interações nesse momento. Isso porque estão sempre em questão facetas agonísticas das relações, seja por conta de antigos conflitos, seja pela contínua produção de distinções significativas nos espaços de interação e sociabilidade.

Já o parentesco é, por sua parte, ao lado da festa religiosa, o outro vetor que alimenta os fluxos da dinâmica circular. Existe também um esforço dos agentes para manter os vínculos familiares mesmo mediante os afastamentos, expresso de diversas maneiras. Essas relações mantidas transnacionalmente são também o que suporta qualquer ideia de formação de um campo social transnacional. A ideia de um transnacionalismo precisa ser notada através das práticas dos agentes mais do que por meio de aportes metodológicos.

Portanto, o parentesco engendra vínculos transnacionais mediante os afastamentos inerentes à migração, mas é preciso também dizer que se reinventa no contexto do retorno, recriado em agosto pela atualização das relações familiares. A constante e mútua frequentação das casas de emigrantes a aldeões produz contextos de interação que

\footnotetext{
198 Pierre Sanchis nota esse aspecto em sua pesquisa sobre as romarias em Portugal: "E os aldeãos, (...) nunca perdem a oportunidade de exaltar os esplendores - por vezes imaginários - da 'sua festa', a mais bela da região. O emigrado, seja jovem ou velho, residente em Lisboa ou na França, mesmo que há vários anos não ponha os pés na sua aldeia, tem sempre a 'intenção' de lá ir para a próxima festa; e muitas vezes está disposto a organizar viagens colectivas: ‘tem que ver aquilo; iremos juntos"”. (1983:15).
} 
em geral reforçam os vínculos de proximidade familiar. As relações familiares não são um dado estável e imutável, mas precisam ser vistas como uma prática, uma produção.

Ademais, as relações construídas são constitutivas da vida social local e transnacionalmente. A partir de uma apreensão do parentesco definido não apenas por meio das relações de consanguinidade, é possível notar que a reconstrução das relações de proximidade e familiaridade nos contextos de destino estrutura práticas de produção da localidade. A reconstituição de um contexto de interações entre imigrantes nas sociedades de destino não apenas serve de suporte para a reprodução da emigração como uma prática de base local, mas sobretudo constitui forma de apropriação do espaço habitado. A fixação em um local passa a ser vislumbrada quando o espaço passa a ser composto pelas inúmeras maneiras de praticá-lo, quando as redes de relações se tornam suficientemente densas. Nesse ínterim de práticas de reterritorialização, destacam-se as relaões encetadas nos espaços da casa e do trabalho.

No entanto, o interesse repetido e continuado dos emigrantes em participar da festa e da vida social da aldeia de modo geral suscita reflexões sobre a formação de dinâmicas transnacionais contemporâneas. Esse tipo de fluxo, que implica em múltiplas filiações em contextos diferentes, emergiu formulado como um problema de especificidades absolutamente novas, sobretudo no que tange a práticas que transcendem as fronteiras nacionais: o trânsito de pessoas, bens e dinheiro por meio de remessas e, sobretudo, as inúmeras formas de produção de localidades.

Pensando nessas práticas é que Arjun Appadurai (1996: 178 e 1997: 34) chama a atenção para os modos de reprodução de dinâmicas culturais executados em contextos de intenso trânsito populacional. Esse quadro característico de processos migratórios Appadurai denomina "desterritorialização", marcado principalmente pelo fato de os objetos observados pelo pesquisador não serem espacialmente delimitados, ou facilmente delimitáveis. Segundo o autor, as práticas desses grupos dependem cada vez menos que quadros espaciais precisos e são pautadas por um crescente uso da "imaginação" como vetor de produção de modos de vida nunca antes pensados.

Embora seu intento seja demonstrar como, por meio dessa prática intensificada da imaginação da vida social, as formas culturais encontram caminhos para se reproduzir e perpetuar em alguma medida (o que, todavia, abrange de modo bastante elástico processos de mudança e transformação nas práticas e representações dos grupos), é pre- 
ciso matizar as percepções do fenômeno ocasionadas pelo uso da noção de desterritorialização.

Muito embora sejam infinitos os modos de invenção de práticas coletivas, mesmo inseridos em processos transfronteiriços, os grupos se reportam continuamente a territórios específicos. O território reaparece em meio à mobilidade dos grupos por meio dos usos e formas de apropriação do espaço. Quando o espaço passa a ser utilizado e investido de significados estamos diante de novas configurações territoriais, talvez menos perenes, porém não menos verdadeiras para os grupos. É o que procuro perceber como "produção de localidades", recuperando o modo como Appadurai a descreve sem, contudo, tomar a desterritorialização como um impulso sem mão-dupla.

Principalmente quando o foco se dá sobre processo migratórios, é importante considerar, como faz Rogério Haesbaert, que nesses casos "a mobilidade é mais um meio que um fim, uma espécie de intermediação numa vida em busca de certa estabilidade" (2004: 245). A migração, tomada em sua complexidade, precisa remeter aos contextos em que o migrante se insere e que ajuda a produzir. O que pude perceber foi que, nesse ínterim, há tantos processos de "reterritorialização" quanto são os de desterritorialização. Acompanhando Haesbaert, entendo que a emigração observada etnograficamente em Vilas Boas revela formas de territorialização, percebidas através da capacidade dos agentes de "construir e/ou controlar fluxos/redes e criar referenciais simbólicos num espaço em movimento, no e pelo movimento" (Idem: 280). Desse modo, a própria prática do retorno constitui uma forma de produzir reterritorializações.

O retorno figura como uma prática de deslocamento transnacional que fundamenta a temporalidade aldeã, modo pelo qual o global se enreda ao plano local. No quadro social ocasionado pelo retorno dos emigrantes, o encontro é um momento condensado de atualização de relações e posições sociais. Enquanto formas de distinção e diferenciação social são inventadas e designam fronteiras simbólicas e hierarquias, as relações são reavaliadas contingencialmente e podem mudar de estatuto, em um jogo relacional de modulação de interesses, entendimentos e conflitos.

Modos distintos de produzir, perceber e se inserir na aldeia se aglutinam na festa. Diversas formas de representação das trajetórias migrantes se sobrepõem e ganham destaque aquelas que se realizam por meio do consumo conspícuo, do dispêndio. Se a dimensão do poder econômico dos emigrantes se espetaculariza no contexto social do 
retorno, como forma de atestar o sucesso econômico de sua empreitada migratória, é também porque representa um momento de inversão do comedimento vivido nos contextos de destino. Por outro lado, diante disso, alguns aldeões reavaliam na duração desse momento a possibilidade latente de emigrar. Outros preferem ainda condenar moralmente o modo expansivo de vivência da festa, os excessos vistosos. No entanto, toda a euforia festiva, o gozo da celebração, os excessos e esbanjamentos se enfeixam e coadunam na queima de fogos de artifício que encerra as comemorações na noite do dia quinze, sacrifício final oferecido à memória dos que comemoram, pelo menos até o ano seguinte.

No final das contas, existe um nível em que Haesbert e Appadurai terminam por concordar quando pensamos que o território permanece de alguma forma ou em alguma medida. Ligado à memória ou ao imaginário ${ }^{199}$, é em torno do território que se produzem identificações e reproduzem práticas. A questão é que, embora por vezes seja acentuadamente simbólico, o território encontra sempre um lastro material onde se firma por meio dos usos dos agentes.

Por fim, os afastamentos se processam autorizados pelas despedidas e no restante do tempo a aldeia continua sua participação no campo social transnacional por meio dos contatos esporádicos, remessas, telefonemas e eventuais, rápidos e excepcionais retornos de alguns emigrantes ao longo do ano. Quando retornam para os contextos produzidos nos países de destino, os emigrantes mais uma vez distendem as relações firmadas na aldeia. No mais, a expectativa de repetir a experiência festiva é a constante que permeia o imaginário emigrante, que distende transnacionalmente as práticas, relações e memórias, a vida social de modo integral, enfim.

\footnotetext{
199 Sobretudo para o emigrante, "a aldeia distante torna-se o ponto de referência emocional, ganhando uma representação imaginária que a identifique e caracterize, por via da adopção de um conjunto de símbolos distintivos" (ROCHA-TRINDADE, 1987: 727). A aldeia, lembrada de longe, se eleva à condição de paisagem imaginada, singularíssimo lócus da pertença.
} 


\section{BIBLIOGRAFIA}

ANDERSON, Benedict. Comunidades Imaginadas. Reflexões sobre a origem e difusão do nacionalismo. São Paulo: Companhia das Letras, 2008.

AGIER, Michel. "Os saberes urbanos da antropologia”, in: Antropologia da cidade: lugares, situações, movimentos. São Paulo: Terceiro Nome, 2011, pp.59-88. . "Distúrbios identitários em tempos de globalização", in: Revista Mana, Rio de Janeiro: vol. 7 (n. 2), pp.7-33, Out. 2001.

AHMED, Sara. "Home and away: Narratives of migration and estrangement", in: International Journal of Cultural Studies, v.2, n.3, pp.329-347, 1999.

ALMEIDA, Miguel Vale de. "Da terra à pedra: trabalho, poder e conflito", in: Senhores de Si: uma interpretação antropológica da masculinidade. Lisboa: Fim de Século Edições, 2000, pp.157-180.

"Na companhia dos homens: sociabilidades masculinas", in: Senhores de Si: uma interpretação antropológica da masculinidade. Lisboa: Fim de Século Edições, 2000b, pp.181-210.

AMOEDO, Diego. "O Camiño Privilexiado": transformações socio-territoriais em uma aldeia rural fronteiriça entre Galícia (Es) e Portugal”. Trabalho apresentado nas Jornadas de Antropologia da UNICAMP, 2012.

ANTUNES, M. L. Marinho. "Migrações, mobilidade social e identidade cultural: factos e hipóteses sobre o caso português”, in: Revista Análise Social, vol. XVII (65), 1981 (1), pp.17-27.

APPADURAI, Arjun. “Soberania sem territorialidade. Notas para uma geografia pósnacional". Novos Estudos, no. 49, novembro 1997, pp. 33-46.

. Modernity at large. Cultural dimension of globalization. University of Minnesota Press, 1996.

. "Introdução: mercadorias e a política de valor", in: A vida social das coisas. As mercadorias sob uma perspectiva cultural. Niterói: Editora da Universidade Federal Fluminense, 2010, pp.15-88. 
BACHELARD, Gaston. A Poética do Espaço. São Paulo: Martins Fontes, 1996 [1957].

BARTH, Fredrik. "Os grupos étnicos e suas fronteiras" [1969] in: LASK, Tomke (org.)

O guru, o iniciador e outras variações antropológicas. Rio de Janeiro: Editora Contra Capa, 2000.

BARRETO, Gilsa Rojas. "Festa dos Três Reis Santos: festa religiosa de um bairro rural”, in: LUCENA, Célia T. e GUSMÃO, Neusa M.M. (orgs.) Discutindo Identidades. São Paulo: Assoc. Editorial Humanitas, FAPESP/NAP-CERU-USP, 2006, pp.162-176. BASTOS, Cristiana. "Montes e aldeia no nordeste algarvio", in : O'NEILL, Brian J. e BRITO, Joaquim P. Lugares de Aqui. Actas do seminário “Terrenos Portugueses”. Lisboa : Publicações Dom Quixote, 1991

BASTIDE, Roger. "Mémoire collective et sociologie du bricolage", Bastidiana, 7-8, 1994.

. Sagrado Selvagem e outros ensaios. São Paulo: Cia. das Letras, 2006 [1975].

BOSI, Ecléa. "Memória-sonho e memória-trabalho", in: Memória e Sociedade: lembranças dos velhos. São Paulo: Companhia das Letras, 2009, pp.5-30. . "A substância social da memória", in: Memória e Sociedade: lembranças dos velhos. São Paulo: Companhia das Letras, 2009, pp.329-400.

BOTO, Daniel Filipe da C. "Aquele querido mês de Agosto”. Análise do filme de Miguel Gomes. Dissertação de mestrado apresentada ao Programa de Pós-Graduação em Estudos Artísticos da Faculdade de Letras de Coimbra, Coimbra, 2009.

BOURDIEU, Pierre. "O camponês e seu corpo", in: Revista de Sociologia e Política, n²6, jun. 2006, pp.83-92.

BOURDIEU, Pierre. "Prefácio. Um analista do inconsciente", in : SAYAD, Abdelmalek. A imigração ou os paradoxos da alteridade. São Paulo : Edusp, 1998, pp.9-12. . "L'illusion biographique" In: Actes de la recherche en sciences sociales. Vol. 62-63, juin 1986. pp. 69-72. . “Comprendre” in: BOURDIEU, P. (org.) La Misère du Monde. Paris: Éditions du Seuil, 1993, pp.903-925.

BRANDÃO, Carlos Rodrigues. A Partilha da Vida. São Paulo: Cabral Editora, 1995. 
BRANDÃO, Maria de Fátima S. “O bom emigrante à casa torna?”, in : SILVA, M. B. et al (orgs.) Emigração/Imigração em Portugal. Actas do Colóquio Internacional sobre Emigração e Imigração em Portugal, Séculos XIX e XX. Algés: Fragmentos Editorial, pp.163-183, 1993.

BRETTELL, Caroline B. Homens que partem, mulheres que esperam. Consequências da emigração numa freguesia minhota. Lisboa; Publicações Dom Quixote, 1991.

BRETTELL, Caroline B. Anthropology and Migration. Essays on transnationalism, ethnicity and identity. Altamira Press, 2003.

. "Kinship and Contract: Property Transmission and Family Relations in Northwestern Portugal", in: Comparative Studies in Society and History, Vol. 33, No. 3 (Jul., 1991b), pp.443-465.

. "Adjustment of Status, Remittances, and Return: Some Observations on 21st Century Migration Processes", in: City \& Society, Vol. 19, Issue 1, 2007, pp.4759.

BRITO, Joaquim Pais de (1996) "Coerência, incerteza e ritual no calendário agrícola”, in: BRITO, Joaquim Pais de, e outros (coords.). O Vôo do Arado. Lisboa; Museu Nacional de Etnologia, pp.217-228.

. “A taberna: lugar e revelador da aldeia”, in: O’NEILL, Brian J. e

BRITO, Joaquim P. Lugares de Aqui. Actas do seminário “Terrenos Portugueses”. Lisboa : Publicações Dom Quixote, 1991, pp.167-200.

. Lugares de Aqui. Actas do seminário “Terrenos Portugueses”. Lisboa : Publicações Dom Quixote, 1991, pp.103-118.

CAMARGO, Luiz Otávio de L. “Apresentação: consumo e cultura material”, in: CAMARGO, Luiz Otávio de L. e BUENO, Maria Lucia (orgs.) Cultura e consumo: estilos de vida na contemporaneidade. São Paulo: Editora Senac, 2008, pp.17-24.

CANCLINI, Néstor Garcia. “O consumo serve para pensar”, in: Consumidores e Cidadãos. Conflitos multiculturais da globalização. Rio de Janeiro: Editora UFRJ, 1996, pp.51-69.

. "Festa e história: celebrar, recordar, viver", in: As culturas populares no capitalismo. São Paulo: Editora Brasiliense, 1983, pp.112-132. 
CARSTEN, Janet. "Introduction" e "Houses of memory and kinship" in: After Kinship. Cambridge University Press, 2004, pp.1-56.

CARSTEN, J. e HUGH-JONES, S. "Introduction: about the house - Lévi-Strauss and beyond", in CARSTEN, J. e HUGH-JONES, S. (orgs.) About the house - Lévi-Strauss and beyond. Cambridge University Press, 1995, pp.1-46.

CASTELO, Cláudia. Passagens para áfrica: o povoamento de angola e moçambique com naturais da metrópole. Porto: Edições Afrontamento, 2007.

CAVALCANTI, Maria Laura V. C. "Ritual, drama e performance na cultura popular: uma conversa entre a antropologia e o teatro", Série Passagens, n.12. Jan. 2011, UFRJ. Disponível em http://www.lauracavalcanti.com.br/publicacoes.asp\# “Os sentidos no espetáculo", in: Revista de Antropologia, São Paulo: USP, 2002, v.45, no.1, pp.37-78.

CAVALCANTI, Maria Laura V. C e GONÇALVES, José Reginaldo S. "Cultura, Festas e Patrimônios", in: Horizontes das ciências sociais. Antropologia. Coordenador geral Carlos Benedito Martins; Coordenador de área Luiz Fernando Dias Duarte. - São Paulo: Anpocs, Co-edição Instituto Ciência Hoje, Editora Barcarolla e Discurso Editorial, 2010, pp.259-292.

CERQUEIRA, Cristina. "Matança do porco, festa da matança e mudanças sociais na serra do barroso (trás-os-montes)", in: IV Congresso Português de Sociologia, 2000. Disponível em: http://www.aps.pt/cms/docs_prv/docs/DPR462dee3224a14_1.PDF

CERTEAU, Michel de. "Introdução Geral", in: A Invenção do Cotidiano, vol.1: Artes de Fazer. Petrópolis: Editora Vozes, pp.37-56, 1994. "Práticas de Espaço", in: A Invenção do Cotidiano, vol.1: Artes de Fazer. Petrópolis: Editora Vozes, pp.157-198, 1994.

CLIFFORD, James. "Culturas viajantes”, in: ARANTES, A. A. (Org.) O espaço da diferença. Campinas, SP: Papirus, 2000, pp.50-79.

COMERFORD, John Cunha. "Mapeamentos, familiarização e reputações: a sociabilidade agonística na roça", in: Como uma família. Sociabilidade, territórios de parentesco e sindicalismo rural. Rio de Janeiro: Relume Dumará, 2003, pp.25-139.

CONNERTON, Paul. "Cerimônias comemorativas", in: Como as sociedades recordam. Oeiras: Celta Editora, 1993, pp.49-86. 
CORDEIRO, Albano. “La communauté portugaise en France”, in: SILVA, M. B. et al (orgs.) Emigração/Imigração em Portugal. Actas do Colóquio Internacional sobre Emigração e Imigração em Portugal, Séculos XIX e XX. Algés: Fragmentos Editorial, pp.362-370, 1993.

CORDEIRO, Graça Índias. "Ruas em festa nos Santos Populares", in: Um Lugar na Cidade. Quotidiano, Memória e Representação no Bairro da Bica. Lisboa: Publicações Dom Quixote, 1997, pp.227- 268. . "O bairro como prática, projeto e representação", in: Um Lugar na Cidade. Quotidiano, Memória e Representação no Bairro da Bica. Lisboa: Publicações Dom Quixote, 1997, pp.317-324.

CORDEIRO, Graça Índias e FRÚGOLI JR. Heitor. "Prefácio", in: AGIER, M. Antropologia da Cidade. Lugares, Situações, Movimentos. São Paulo; Editora Terceiro Nome, 2011, pp.9-29.

CUNHA, Manuela Carneiro da. "Conclusão", in: Negros, estrangeiros. Os escravos libertos e sua volta à África. São Paulo: Brasiliense, 1985, pp.205-209.

DAWSEY, John Cowart. De que riem os "boias-frias”? Walter Benjamin e o teatro épico de Brecht em carrocerias de caminhões. Tese de livre-docência em antropologia social pela Faculdade de Filosofia, Letras e Ciências Humanas da Universidade de São Paulo, 1999.

DOUGLAS, Mary e ISHERWOOD, Baron. O mundo dos bens: para uma antropologia do consumo. Rio de Janeiro: Ed. UFRJ, 2004 [1979].

DOUGLAS, Mary. “O mundo dos bens, vinte anos depois”, in: Horizontes Antropológicos, v.13, n.28 Porto Alegre jul./dez. 2007.

DURHAM, Eunice R. "Migrantes rurais", in: A dinâmica da cultura: ensaios de antropologia. São Paulo: Editora Cosac Naify, 2004, pp.181-202. "Comunidade", in: A dinâmica da cultura: ensaios de antropologia.

São Paulo: Editora Cosac Naify, 2004, pp.219-226. . A Caminho da Cidade. A vida rural e a migração para São Paulo. São Paulo: editora Perspectiva, 1984. 
DURKHEIM, Émile. "Introdução. Objeto da Pesquisa. Sociologia religiosa e teoria do conhecimento", in: As formas elementares da vida religiosa. São Paulo: Martins Fontes, 2003, pp.V-XXVII.

DUVIGNAUD, Jean. "Prefácio", in: HALBWACHS, M. A Memória Coletiva. São Paulo: Edições Vértice, pp.9-17, 1990 [1968].

ECKERT, Cornelia. Memória e trabalho: etnografia da duração de uma comunidade de mineiros de carvão (La Grand-Combe, França). Curitiba: Appris, 2012.

ELIAS, Norbert e SCOTSON, John L. “Introdução: ensaio teórico sobre as relações estabelecidos-outsiders", in: Os estabelecidos e os outsiders: sociologia das relações de poder a partir de uma pequena comunidade. Rio de Janeiro: Jorge Zahar, 1999, pp.1950.

EVANS-PRITCHARD, Edward E. Os Nuer. Uma descrição do modo de subsistência e das instituições políticas de um povo nilota. São Paulo: Perspectiva, 2005 [1940].

FALZON, Mark-Anthony (editor). Multi-sited Ethnography. Theory, praxis and locality in contemporary research. Ashgate Publishing Limited, 2009.

FAVRET-SAADA, Jeanne. "Ser Afetado" [1990] in: Cadernos de Campo, revista dos alunos de Pós-Graduação em Antropologia Social da USP, no.13, pp.155-161, 2005.

FELDMAN-BIANCO, Bela. Immigration, Saudade and the Dialectics of deterritorialization and reterritorialization. Oficina do CES no.46, Centro de Estudos Sociais, Coimbra, 1995.

. “A Criação de uma Nação (Portuguesa) Desterritorializada e a Transnacionalização de Famílias", in: Cadernos CERU, no.6 - série 2, 1995.

. "Reinventando a localidade: globalização heterogênea, escala da cidade e a incorporação desigual de migrantes transnacionais", in: Horizontes Antropológicos, Porto Alegre, ano 15, n.31, pp.19-50, jan./jun. 2009.

FIORI, A.; ANDRADE, J. A.; TESTA, A. Q.; TAMBUCCI, Y. B. “Diálogo Vagueiros: Vida Movimento e Antropologia. Entrevista com o professor Tim Ingold", in: Revista Ponto.Urbe, No.11, Ano 6, Dez. 2012. 
FREITAS, Caroline Cotta de Mello. A arquitetura de um projeto migratório: representação, memória e "cosmologia salazarista" entre imigrantes portugueses em São Paulo. Dissertação (Mestrado), 2004, PPGAS/USP.

FRIEDMAN, Jonathan. "Introduction”, in: Consumption and Identity. Amsterdam: Overseas Publishers Association, 1994, pp.1-16.

FRÚGOLI JR., Heitor. Sociabilidade urbana. Rio de Janeiro: Jorge Zahar Editor, 2007. . "Relações entre múltiplas redes no Bairro Alto", in: Revista Brasileira de Ciências Sociais (RBCS), vol.28, n82, junho 2013, pp.17-31.

GARDNER, Katy e GRILLO, Ralph. "Transnational households and ritual: an overview", in: Global Networks 2, 3 (2002), pp.179-190.

GEERTZ, Clifford. "Um jogo absorvente: nota sobre a briga de galos balinesa", in: $A$ interpretação das Culturas. Rio de Janeiro: LTC, 1989, pp. 278-321.

GELL, Alfred. (2010) "Recém-chegados ao mundo dos bens: o consumo entre os Gonde Muria”, pp.143-178 in: A vida social das coisas. As mercadorias sob uma perspectiva cultural. Niterói: Editora da Universidade Federal Fluminense.

GLICK-SCHILLER, Nina. "Transnationality” in: NUGENT, David and VINCENT, Joan (eds.). A Companion to the Anthropology of Politics. Blackwell Publishing ltd., 2004, pp.448-467.

GLICK-SCHILLER, Nina e LEVITT, Peggy. "Conceptualizing Simultaneity: A Transnational Social Field Perspective on Society" in: International Migration Review, Vol. 38, No.3, Conceptual and Methodological Developments in the Study of International Migration (Fall, 2004), pp. 1002-1039.

GLICK-SCHILLER, Nina; BASCH, Linda; SZANTON-BLANC, Cristina. "From Immigrant to Transmigrant: Theorizing Transnational Migration" in: Anthropological Quarterly, Vol.68, No.1 (Jan., 1995), pp. 48-63.

GLICK-SCHILLER, Nina e ÇAGLAR, Ayse. "Locality and Globality. Building a Comparative Analitycal Framework in Migration and Urban Studies" in: Locating Migrations. Rescaling Cities and Migrants. Ithaca and London: Cornell University Press, 2011, pp.60-81. 
GLICK-SCHILLER, Nina e WIMMER, Andreas. "Methodological Nationalism and Beyond. Nation-State Building, Migration and the Social Sciences”. Global Networks, No. 2-4, 2002.

GLUCKMAN, Max. "A História na análise e reconstrução de processos sociais: Análise de uma situação social no Zululândia moderna" in: Antropologia das Sociedades Contemporâneas. FELDMAN-BIANCO, Bela (org.). São Paulo: Editora UNESP, 2010. GOLDMAN, Marcio e NEIBURG, Frederico. "Da nação ao império: a guerra e os estudos do “caráter nacional”, in: L'ESTOILE,B.; NEIBURG, F. e SIGAUD, L. (Orgs.) Antropologia, Impérios e Estados Nacionais. Rio de Janeiro: Relume Dumará, 2002, pp.187-217.

GUARINELLO, Norberto L. "Festa, trabalho e cotidiano" in: JANCSÓ, I. e KANTOR, I. (orgs.) Festa. Cultura e sociabilidade na América Portuguesa, vol.II. São Paulo; Hucitec/Edusp/FAPESP/Imprensa Oficial, 2001, pp.969-975.

GUÉRIOS, Paulo R. “As condições sociais de produção das lembranças entre imigrantes ucranianos", Revista MANA, 14(2) : 367-398, 2008.

GUPTA, Akhil. "Imagining nations", in: NUGENT, David and VINCENT, Joan (eds.). A Companion to the Anthropology of Politics. Blackwell Publishing ltd., 2004, pp.267281. . "The song of the Nonaligned World: transnational identities and the reinscription of space in late capitalism", in: Cultural Anthropology, vol.7, no.1, pp.6379, fev. 1992.

GUPTA, Akhil e FERGUSON, James. "Mais além da "cultura": espaço, identidade e política da diferença”, in: ARANTES, A. A. (Org.) O espaço da diferença. Campinas, SP: Papirus, 2000, pp.30-49.

HAESBAERT, R. O mito da desterritorialização: do "fim dos territórios" à multiterritorialidade. Rio de Janeiro: Bertrand Brasil, 2010. "Da Desterritorialização à Multiterritorialidade". Boletim Gaúcho de Geografia, Porto Alegre, v. 29, n.1, p. 11-24, 2003. . "Região, diversidade territorial e globalização". GEOgraphia (UFF), Niterói, v. 1, n.1, p. 15-39, 1999. 
HALBWACHS, Maurice. A Memória Coletiva. São Paulo: Edições Vértice, 1990. La mémoire collective [1950]. Édition critique établie par Gérard Namer. Paris, Albin Michel, 1997.

JAISSON, Marie. "Temps et espace chez Maurice Halbwachs (1925-1945)", Revue d'Histoire des Sciences Humaines, 1999/1 no.1, p. 163-178.

HALL, Stuart. “A questão da Identidade Cultural”. Textos Didáticos, $n^{\circ} 18$. EdUnicamp, Fevereiro de 1998. . "Pensando a diáspora. Reflexões sobre a terra no exterior", in: $D a D i$ áspora. Identidades e Mediações Culturais. Belo horizonte, Editora UFMG, pp.25-48, 2003.

HANNERZ, Ulf. Conexiones Transnacionales. Cultura, Gente, Lugares. Madrid: Ediciones Cátedra, 1998.

HERCULANO, Alexandre. Opúsculos II. Lisboa: Tavares Cardoso \& Irmão, 1879. HIRSCHMAN, Charles. "The role of the religion in the origins and adaptation of immigrant groups in the United States", in: PORTES, A. e WIND, J. (orgs.) Rethinking Migration. New theoretical and empirical perspectives. Berghahn Books: New York / Oxford, 2008, pp.391-418.

HOBSBAWM, Eric. e RANGER, Terence (orgs.). "Introdução: A Invenção das Tradições”, in: A Invenção das Tradições. Rio de Janeiro: Paz e Terra, 1997, pp.9-23.

LEACH, Edmund. "Dois ensaios a respeito da representação simbólica do tempo", in: Repensando a antropologia. São Paulo: Perspectiva, 2006, pp.191-209.

LEAL, João (1996). "Festa e Emigração numa Freguesia Açoriana”, in: BRITO, Joaquim Pais de, e outros (coords.). O Vôo do Arado. Lisboa: Museu Nacional de Etnologia, pp.583-590.

. "Traditions locales et émigration: les fêtes du Saint-Esprit aux Açores", in: Revue Ethnologia Française, 2000/2001, pp.51-60.

. "Rituais em trânsito. Festas do Espírito Santo, transnacionalidade, etnicidade", in: GODINHO, P., BASTOS, S. e FONSÊCA, I. (coords.), Jorge Crespo Estudos em Homenagem. 100Luz Editorial, 2009, pp.67-90. 
LEANDRO, Maria Engrácia. "Portugueses na região parisiense. Reinvenção nos laços sociais", in: SILVA, M. B. et al (orgs.) Emigração/Imigração em Portugal. Actas do Colóquio Internacional sobre Emigração e Imigração em Portugal, Séculos XIX e XX. Algés: Fragmentos Editorial, pp.348-361, 1993.

LEITE, Joaquim C. "Informação ou propaganda? Parentes, amigos e engajadores na emigração oitocentista”, in: SILVA, M. B. et al (orgs.) Emigração/Imigração em Portugal. Actas do Colóquio Internacional sobre Emigração e Imigração em Portugal, Séculos XIX e XX. Algés: Fragmentos Editorial, pp.98-107, 1993.

LEMOS MONTEIRO, Tiago José. Tudo isto é Pop. Portugalidades musicais contemporâneas entre a 'tradição' e a 'modernidade'. Tese de Doutorado apresentada ao Programa de Pós-Graduação em Comunicação da Universidade Federal Fluminense (UFF), Niterói, 2012.

LÉVI-STRAUSS, Claude. “Clã, linhagem, casa”, in: Minhas Palavras. São Paulo: Brasiliense, 1986, pp.185-238.

. O Pensamento Selvagem. Campinas, SP: Papirus Editora, 1989.

LEVITT, Peggy. "Social Remittances: How Global Culture is Created Locally", in: The Transnational Villagers. Berkeley: University of California Press, 2001, pp.54-69.

"Social Remittances: Migration Driven Local-Level Forms of Cultural Diffusion”, in: International Migration Review, Vol. 32, No. 4 (Winter, 1998), pp. 926948

MACHADO, Igor José de Renó. "Interação das fronteiras e o ponto de vista etnográfico: dinâmicas migratórias recentes em Governador Valadares", in: Horizontes Antropológicos, Porto Alegre, ano 15, n. 31, pp.167-187, jan./jun. 2009.

. "O ponto de vista das famílias: etnografia sobre os emigrantes internacionais valadarenses (Brasil)", in: PADILLA, Beatriz e XAVIER, Maria (orgs.) Revista Migrações, no.5, out. 2009b, pp. 155-168.

"Reordenações da casa no contexto migratório de Governador Valadares, Brasil", in: Etnográfica 14 (1), fev. 2010, pp.5-26.

"Kinship and differentialities: Alternatives to identity and ethnic frontiers in the study of migrations", in: Vibrant, v.8, no.2, 2011, pp.219-235. 
. "Lugar ampliado, espaço e poder", in: Campos, 2: 2002, pp.101-115.

MAHE, Pierre. "Religiosité populaires (des portugais)", in: ROCHA-TRINDADE, M.

B. e RAVEAU, F. H. M. (orgs.) Presence Portugaise em France. Lisboa: Centro de Estudos das Migrações e das Relações Interculturais (CEMRI), Universidade Aberta, pp.243-258, 1998.

MARCUS, George. "Ethnography in/of the World System. The Emergence of MultiSited Ethnography", in: Ethnography Through Thick and Thin. Princeton University Press, 1995.

MAUSS, Marcel. "Ensaio sobre a dádiva”, in: Sociologia e Antropologia. São Paulo: Cosac \& Naify, 2003, pp.185-314.

MITCHELL, James Clyde. "A dança Kalela: aspectos das relações sociais entre africanos urbanizados na Rodésia do Norte", in: FELDMAN-BIANCO, Bela (org.) Antropologia das Sociedades Contemporâneas. Métodos. São Paulo: Editora Unesp, 2010, pp.365-436.

MONTEIRO, Paulo Filipe. Emigração. O eterno mito do retorno. Oeiras: Celta Editora, 1994.

. "Emigrantes imigrados: da Lousã ao Connecticut, uma investigação em dois tempos", in: SILVA, M. B. et al (orgs.) Emigração/Imigração em Portugal. Actas do Colóquio Internacional sobre Emigração e Imigração em Portugal, Séculos XIX e XX. Algés: Fragmentos Editorial, pp.323-347, 1993.

OKELY, Judith. "Anthropology and autobiography. Participatory experience and embodied knowledge", in: OKELY, J. e CALLAWAY, H. (Orgs.) Anthropology and Autobiography. London Routledge, ASA Monpgraphs, 1992, pp.1-28.

OLIVEIRA, Ernesto Veiga de. "Romarias", in: Festividades Cíclicas em Portugal. Lisboa: publicações Dom Quixote, 1995, pp. 217-227.

O’NEILL, Brian Juan. "Espaços sociais e grupos sociais no nordeste trasmontano”, in: O’NEILL, Brian J. e BRITO, Joaquim P. Lugares de Aqui. Actas do seminário "Terrenos Portugueses”. Lisboa : Publicações Dom Quixote, 1991, pp.141-166.

PAULO, Heloísa (2000). "O Salazarismo e o lugar do emigrante no ideal de "Nação" no Estado Novo", in: Aqui também é Portugal. A colónia portuguesa do Brasil e o Salazarismo. Coimbra: Quarteto Editora, pp.31-58. 
. "Da aldeia à Pátria: o terreno e as formas para a divulgação do salazarismo na colónia", in: Aqui também é Portugal. A colónia portuguesa do Brasil e o Salazarismo. Coimbra: Quarteto Editora, 2000, pp.247-318.

PEIRANO, Mariza. "Rituais como estratégia analítica e abordagem etnográfica", in: $O$ Dito e o Feito. Ensaios de antropologia dos rituais. Rio de Janeiro: Relume Dumará, 2001, pp. 7-14.

PEIXOTO, João. "Migrações e mobilidades: as novas formas da emigração portuguesa a partir de 1980”, in: SILVA, M. B. et al (orgs.) Emigração/Imigração em Portugal. Actas do Colóquio Internacional sobre Emigração e Imigração em Portugal, Séculos XIX e XX. Algés: Fragmentos Editorial, pp.278-307, 1993.

PEREIRA, João Baptista B. (1982). "Emigração e vida rural em Portugal” in: Revista de Antropologia, vol.25. São Paulo.

PÉTONNET,Colette. On est tous dans le brouillard. Essais d'ethnologie urbaine. Paris: CTHS Éditions, 2012.

. "Habitudes alimentaires et acculturation", in: Le Groupe Familial, n.99 (Avril-juin, À boire et à manger), 1983, pp.60-64.

PEREZ, Léa Freitas. "Dionísio nos trópicos: festa religiosa e barroquização do mundo Por uma antropologia das efervescências coletivas", in: PASSOS, Mauro (org.). Festa na Vida. Significado e Imagens. Petrópolis: Editora Vozes, 2002, pp.15-58. . "Introdução", in: Festa como perspectiva e em perspectiva. Rio de Janeiro: Garamond, 2012, pp.21-43.

PINA-CABRAL, João de. “A herança de Maine”, in: Os Contextos da Antropologia. Lisboa: Difel, 1991, pp.109-133.

. O Homem na Família. Cinco ensaios de antropologia. Lisboa: ICS, Imprensa de Ciências Sociais, 2003. . Sons of Adam, daughters of Eve. The peasant Worldview of the Alto Minho. Clarendon Press, Oxford, 1986.

PITT-RIVERS, Julian. "Honour and social status", in: Honour and Shame. The Values of Mediterranean Society. The University of Chicago Press, 1966, pp.19-77. 
POINARD, Michel. "Emigrantes portugueses: o regresso”, in: Revista Análise Social, vol. XIX (75), 1983 (1), pp.29-56.

PORTELA, José e NOBRE, Sílvia. "Entre Pinela e Paris: emigração e regressos", in: Revista Análise Social, vol. XXXVI (161), 2001, pp.1105-1146.

RAMOS, Rui. “A Invenção de Portugal”, in: História de Portugal. A Segunda Fundação (1890-1926), vol.VI. Lisboa: Editorial Estampa, 1994, pp.565-595. . "A aldeia imaginada" in: FÉLIX, Pedro e CASTELO-BRANCO, Salwa El-Shawan. (orgs.). Vozes do Povo: a folclorização em Portugal. Oeiras: Celta Editora, 2003, pp.419-424.

REIS, Manuela e NAVE, Gil. "Camponeses emigrados e emigrantes regressados. Práticas de emigração e estratégias de regresso duma aldeia da beira interior”, in: Lisboa: Revista Sociologia Ruralis, vol.XXVI, n.1, 1986.

REVEL, Jacques. "Microanálise e construção do social", in: Jogos de Escalas. A experiência da microanálise. Rio de Janeiro: Editora Fundação Getúlio Vargas, 1998, 15-38. . "Micro-história, macro-história: o que as variações de escala ajudam a pensar em um mundo globalizado", in: Revista Brasileira de Educação, vol.15, n.45, set/dez. 2010, pp.434-445.

RIBEIRO, Manuela. "A terra e os camponeses no barroso", in: BRITO, J. P. de, e outros (coords.). O Vôo do Arado. Lisboa; Museu Nacional de Etnologia, pp.344-357, 1996.

ROCHA-TRINDADE, Maria Beatriz. "As micropátrias do interior português", in: $R e$ vista Análise Social, vol. XXIII (98), 1987 (4), pp.721-732. "Les temps mythiques des migrations", in: ROCHA-TRINDADE, M. B. e RAVEAU, F. H. M. (orgs.) Presence Portugaise em France. Lisboa: Centro de Estudos das Migrações e das Relações Interculturais (CEMRI), Universidade Aberta, pp.25-38, 1998.

ROWLANDS, Michael. "The material culture of success ideals and life cycles in Cameroon", in: Consumption and Identity. Amsterdam: Overseas Publishers Association, 1994, pp.106-119. 
SAHLINS, Marshall. Cultura na Prática. Rio de Janeiro: Editora UFRJ, pp.533-560, 2007.

. "O "pessimismo sentimental" e a experiência etnográfica: por que a cultura não é um “objeto" em vias de extinção" (Partes I e II). Revista Mana 3 (1): 41 73, 1997; Mana 3 (2): 103-150, 1997.

SALES, Lilian M. Pinto. Aparições de Nossa Senhora: Mensagens e Peregrinações na Contemporaneidade. Tese de Doutorado defendida junto ao Programa de PósGraduação em Antropologia Social da Universidade de São Paulo (USP), São Paulo, 2008.

. "As aparições de Nossa Senhora em Jacareí: continuidade e modelagem”, in: Ciências Sociais e Religião, Porto Alegre, ano 13, n. 14, p. 67-92, setembro de 2011.

. "Nossa Senhora e o fim dos tempos", in: Antropolítica, Niterói, No.33, pp169-190, 2012.

SANCHIS, Pierre. Arraial: Festa de um Povo. As romarias portuguesas. Lisboa; Publicações Dom Quixote, 1983.

SANTO, Moisés Espírito. A Religião Popular Portuguesa. Lisboa; Assírio \& Alvim, 2000.

Santos, Irène Strijdhorst dos. Les brumes de la mémoire : expérience migratoire et quête identitaire de descendants de migrants portugais de France. Tese de Doutorado. École des Hautes Études en Sciences Sociales, Paris, 2010.

SARRÓ, Ramon, e LIMA, Antónia Pedroso de. "Introdução. Já dizia Malinowski: sobre as condições da possibilidade da produção etnográfica", in: (orgs.). Terrenos Metropolitanos: ensaios sobre produção etnográfica. Lisboa: ICS, Imprensa de Ciências Sociais, 2006, pp.17-34.

SAYAD, Abdelmalek. A imigração ou os paradoxos da alteridade. São Paulo : Edusp, 1998.

SCOTT, Ana Silvia. Os Portugueses. São Paulo: Editora Contexto, 2010.

SERRÃO, Joel, “Conspecto histórico da emigração portuguesa”, Análise Social, XVIII (32), 1970, pp. 597-617. 
"Notas sobre emigração e mudança social no Portugal contemporâneo”, in: Revista Análise Social, vol. XXI (87-88-89), 1985 (3-4-5), pp.995-1004.

SILVANO, Filomena. "Things we see: Portuguese anthropology on material culture", in: Etnográfica 14 (3), out. 2010, pp.497-505.

"Ir à terra - mobilidade transnacional e construção de sedentariedades imaginadas”, BALSA, C. (org.) Relações sociais de espaço, homenagem a Jean Remy. Lisboa: Colibri, 2006, pp.199-218.

SIMMEL, Georg. “A sociabilidade. Exemplo de sociologia pura ou formal”, in: Questões Fundamentais da Sociologia. Rio de Janeiro: Jorge Zahar Editor, 2006, pp.59-82. "O Estrangeiro", in: Georg Simmel: Sociologia. Coleção Grandes Cientistas Sociais, vol.34. São Paulo: Ática, 1983, pp.182-188.

SOEIRO DE BRITO, Raquel. "Emigração", in: Portugal. Perfil Geográfico. Lisboa: Editorial Estampa, 1994, pp.104-115.

STRATHERN, Marilyn. "No limite de uma certa linhagem”, entrevista, pp.157-175, in: Mana, vol.5, no 2, out./1999. . "Introdução" in: O gênero da dádiva: problemas com mulheres e problemas com a sociedade na Melanésia [1988]. Campinas: Ed. Unicamp, 2006, pp.2777.

TARRIUS, Alan. "Au-delà des Étas-nations: des sociétés de migrants", in: Revue Européenne des Migrations internationales (2001), vol.17, no.2. Disponível em: http://remi.revues.org/document1944.html

TAVARES, Virgílio. "Vilas Boas", in: Conheça a nossa terra Vila Flor. Mirandela, Portugal: Editora Cidade Berço, 2001, pp.81-86.

TEDLOCK, Barbara. "From Participant Observation to the Observation of Participation: The Emergence of Narrative Ethnography". Journal of Anthropological Research, Vol. 47, No. 1 (Spring, 1991), pp. 69-94.

TURNER, Victor. "Liminaridade e "Communitas", in: O Processo Ritual. Estrutura e Antiestrutura. Petrópolis: Editora Vozes, 1974, pp.116-159.

VAN GENNEP, Arnold. Ritos de Passagem. Petrópolis: Editora Vozes, 2011. 
VERISIANI, Daniela Beccaccia. Autoetnografias. Conceitos alternativos em construção. Rio de Janeiro: 7 Letras, 2005.

VERTOVEC, Steven. “Three meanings of 'diaspora', exemplified among South Asian religions", in: Diaspora 6, no. 3 (1997): 277-299.

VÁSQUEZ, Manuel A. and MARQUARDT, Marie Friedmann. “Theorizing globalization and religion”, in: KHAGRAM, Sanjeev and LEVITT, Peggy (editors). The Transnational Studies Reader. Intersections and Innovations. New York and London:

Routledge, pp.315-332, 2008.

WALL, Karin. "Classe Social, Família e Emigração. Uma análise diferencial das trajectórias dos migrantes de origem rural”, in: SILVA, M. B. et al (orgs.) Emigração/Imigração em Portugal. Actas do Colóquio Internacional sobre Emigração e Imigração em Portugal, Séculos XIX e XX. Algés: Fragmentos Editorial, pp.184-192, 1993.

\section{DOCUMENTOS}

INSTITUTO NACIONAL DE ESTATÍSTICA. Censos 2001 : resultados definitivos : XIV recenseamento geral da população : Instituto Nacional de Estatística. - Lisboa : I.N.E., 2001.

INSTITUTO NACIONAL DE ESTATÍSTICA. Censos 1971 : resultados definitivos : XI recenseamento geral da população : IV recenseamento geral da habitação / Instituto Nacional de Estatística. - Lisboa : I.N.E., 1971 - 8 vols.

\section{INSTITUTE NATIONAL DE LA STATISTIQUE ET DES ÉTUDES} ÉCONOMIQUES (Insee). “Fiches Tématiques. Population Immigrée”, France, 2012.

LEAL, Augusto Soares de Azevedo Pinho. "Villa Flôr", in: Portugal Antigo e Moderno. Diccionario geographico, estatistico, chorographico, heraldico, archeologico, historico, biographico e etymologico. Lisboa: Livraria Editora de Tavares Cardoso \& Irmão, 1886, pp.729-739.

."Villas Bôas", in: Portugal Antigo e Moderno. Diccionario geographico, estatistico, chorographico, heraldico, archeologico, historico, biographico e etymologico. Lisboa: Livraria Editora de Tavares Cardoso \& Irmão, 1886, pp.1398-1409. 


\section{ARTIGOS DE JORNAL}

DIÁRIO NACIONAL, "Verão. Fazer a festa com bombos e touros. O Portugal que troca a praia pelo bailarico", caderno Gente, 29/08/2009.

FOLHA DE PORTUGAL. “100mil portugueses podem ter emigrado”. Disponível em http://folhadeportugal.pt/100-mil-portugueses-podem-ter-emigrado/ (consultado pela última vez em 26/09/2013)

LE FIGARO. "France: 12 millions d'immigrés et d'enfants d'immigrés". Disponível em http://www.lefigaro.fr/actualite-france/2012/10/10/01016-20121010ARTFIG00262-

immigration-les-chiffres-de-l-insee.php?page=\&pagination=3 (consultado pela última vez em $\underline{26 / 09 / 2013)}$

\section{FILMOGRAFIA}

Trás-os-montes, António Reis e Margarida Cordeiro (dirs.), 1976.

Saudade, Bela Feldman-Bianco (dir.), 1991.

Aquele Querido Mês de Agosto, Miguel Gomes (dir.), 2007.

O Salto, Christian de Chalonge (dir.), 1968.

Ganhar a Vida, João Canijo (dir.), 2001.

Fantasia Lusitana, João Canijo (dir.), 2010.

O Bom Povo Português, Rui Simões (dir.), 1981. 